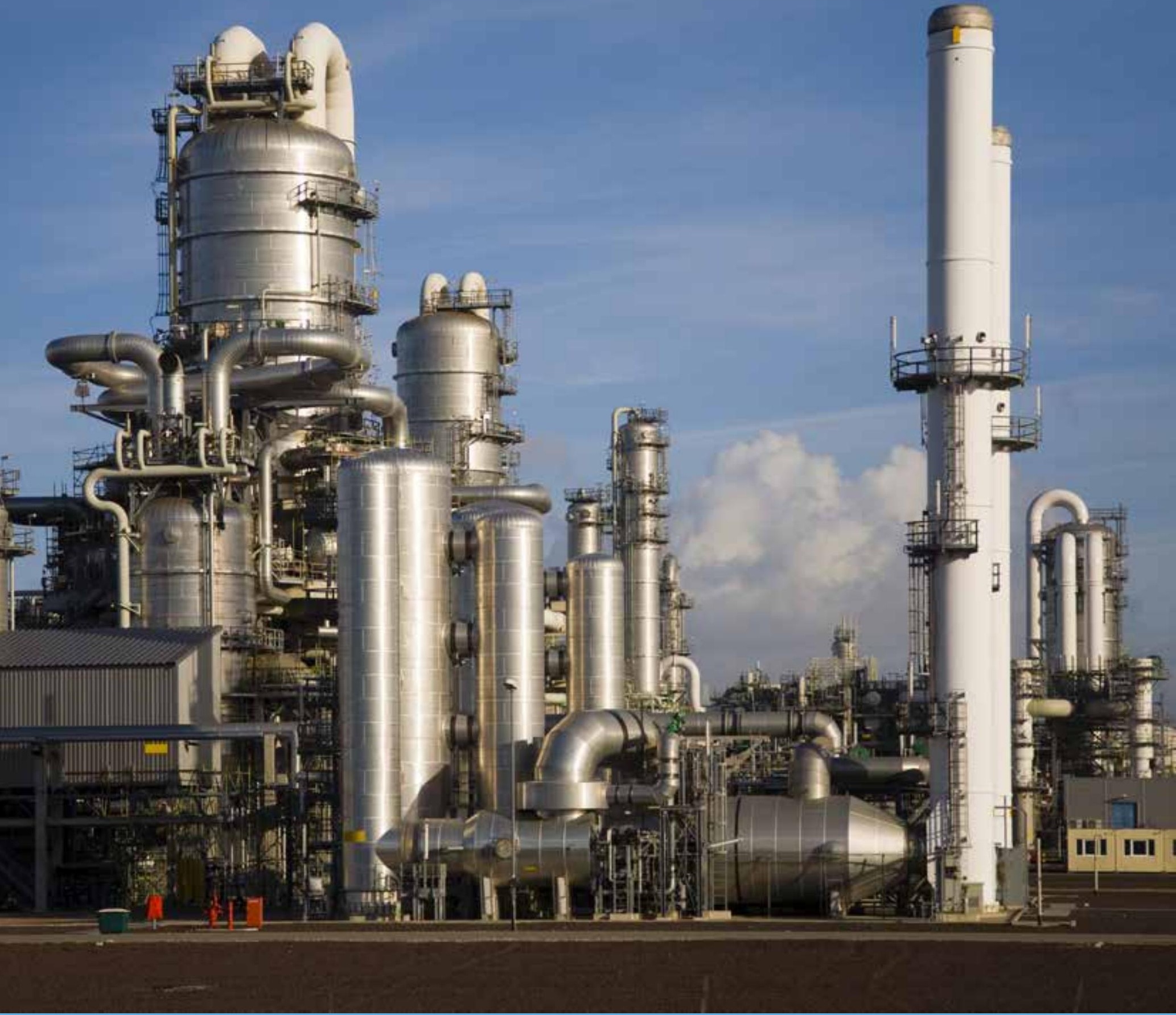

Macroeconomic outlook of sustainable energy and biorenewables innovations (MEV II)

H. van Meijl, I. Tsiropoulos, H. Bartelings, M. van den Broek, R. Hoefnagels, M. Van Leeuwen, E. Smeets,

A. Tabeau and A. Faaij 


\section{Macroeconomic outlook of sustainable energy and biorenewables innovations (MEV II)}

H. van Meijl ${ }^{1}$, I. Tsiropoulos ${ }^{2}$, H. Bartelings ${ }^{1}$, M. van den Broek ${ }^{2}$, R. Hoefnagels ${ }^{2}$, M. Van Leeuwen ${ }^{1}$, E. Smeets $^{1}$,

A. Tabeau ${ }^{1}$ and A. Faaij ${ }^{2}$

1 LEI Wageningen UR

2 Copernicus Institute of Utrecht University

This study was carried out by LEI Wageningen UR and Copernicus Institute of Utrecht University and was commissioned and financed by the topsector platform for knowledge development and innovation of the crosscutting theme bio-based economy (TKI-BBE) and the Dutch Ministry of Economic Affairs (Min EZ). The study is performed within the BE-Basic R\&D programme and project partners Essent, DSM and Corbion provided in-kind contributions to the economic and technical aspects of the work.

LEI Wageningen UR

Wageningen, March 2016 
Van Meijl, H., I. Tsiropoulos, H. Bartelings, M. van den Broek, R. Hoefnagels, M. Van Leeuwen, E. Smeets, A. Tabeau and A. Faaij, 2016. Macroeconomic outlook of sustainable energy and biorenewables innovations (MEV II). Wageningen, LEI Wageningen UR (University \& Research centre), LEI Report 2016-001. 168 pp.; 96 fig.; 40 tab.; 67 ref.

De Nederlandse overheid verwacht dat een grootschalige toepassing van biomassa nodig is om aan de emissiedoelstellingen te voldoen, maar de macro-economische effecten hiervan op de Nederlandse economie zijn onbekend. Deze studie onderzoekt de effecten van een bio-economie op zowel systeemals macro-economisch niveau en toont aan dat de bio-economie positief kan bijdragen aan de Nederlandse economie, het behalen van broeikasgasreductiedoelstellingen en aan het reduceren van de kosten van het terugdringen van broeikasgasemissies. Om deze effecten te realiseren zijn grootschalige technologische veranderingen en wereldwijde markten belangrijk, maar lage prijzen van fossiele energie leiden tot minder macro-economische voordelen. Om de positieve macro-economische effecten en $\mathrm{CO}_{2}$-reductie te realiseren is een stimuleringsbeleid noodzakelijk.

To meet the emission targets, the Dutch government expects that a large-scale deployment of biomass is needed but the macroeconomic impacts on the Dutch economy are unknown. This study analyses the impacts of the bio-based economy at both system and macroeconomic levels and shows that large-scale deployment of biomass up to 2030 positively contributes to the Dutch economy, contributes to meeting the emission reduction targets and to reducing its macroeconomic costs. High technological change and global markets are important to achieve these impacts, but low fossil energy prices reduce the macroeconomic benefits. To achieve the positive macroeconomic impacts and emission reduction, a stimulus by policies is necessary.

Key words: Bioeconomy, macro-economic impacts, technological change, international markets, bottom-up analyses, modelling, renewable energy policies, bio-refineries, Netherlands.

This report can be downloaded for free at http://dx.doi.org/10.18174/370901 or at www.wageningenUR.nl/en/lei (under LEI publications).

(C) 2016 LEI Wageningen UR

P.O. Box 29703, 2502 LS The Hague, The Netherlands, T +31 (0)70 3358330 ,

E informatie.lei@wur.nl, www.wageningenUR.nl/en/lei. LEI is part of Wageningen UR (University \& Research centre).

\section{(cc) BY-NC}

For its reports, LEI utilises a Creative Commons Attributions 3.0 Netherlands license.

\section{(C) LEI, part of DLO Foundation, 2016}

The user may reproduce, distribute and share this work and make derivative works from it. Material by third parties which is used in the work and which are subject to intellectual property rights may not be used without prior permission from the relevant third party. The user must attribute the work by stating the name indicated by the author or licensor but may not do this in such a way as to create the impression that the author/licensor endorses the use of the work or the work of the user. The user may not use the work for commercial purposes.

LEI accepts no liability for any damage resulting from the use of the results of this study or the application of the advice contained in it.

LEI is ISO $9001: 2008$ certified.

LEI 2016-001 | Project code 2271000340

Cover photo: Shutterstock 


\section{Contents}

$\begin{array}{ll}\text { Preface } & 5\end{array}$

$\begin{array}{ll}\text { Summary } & 6\end{array}$

$\begin{array}{ll}\text { Samenvatting } & 15\end{array}$

$\begin{array}{ll}\text { Units and abbreviations } & 25\end{array}$

$\begin{array}{llr}1 & \text { Introduction to MEV II } & 27\end{array}$

$\begin{array}{lll}1.1 & \text { Background } & 27\end{array}$

$\begin{array}{lll}1.2 & \text { Objectives } & 28\end{array}$

$\begin{array}{lll}1.3 & \text { Scope } & 28\end{array}$

1.3.1 Sectors, regions and period $\quad 28$

$\begin{array}{ll}1.3 .2 \text { Policies } & 30\end{array}$

$\begin{array}{ll}1.3 .3 \text { Contents of this report } & 30\end{array}$

$\begin{array}{lll}2.1 & \text { Biorenewable technologies } & 31\end{array}$

2.1.1 Electricity technology mix $\quad 32$

2.1.2 Transport technology mix $\quad 32$

2.1.3 Chemicals technology mix 33

2.1.4 Contribution of biomass in the Dutch energy system $\quad 34$

$\begin{array}{ll}2.1 .5 \mathrm{GHG} \text { emissions } & 37\end{array}$

2.2 Macroeconomic performance $\quad 38$

2.2.1 Share of bio-based technologies in sectors 38

2.2.2 Turnover, value added, energy use, emissions and trade balance $\quad 40$

2.2.3 Multipliers of the bioeconomy 43

2.2.4 Bioeconomy in Dutch provinces $\quad 45$

3

$\begin{array}{lll}3.1 & \text { General overview } & 49\end{array}$

3.2 Scenarios $\quad 50$

3.2.1 Openness of markets: global versus regional biomass supply $\quad 51$

3.2.2 Technical development: LowTech versus HighTech 52

3.2.3 General non-scenario-specific assumptions $\quad 52$

3.3 Bottom-up MARKAL-NL-UU modelling $\quad 54$

3.3.1 Methodological structure $\quad 54$

3.3.2 Input data 55

3.4 Top-down MAGNET modelling $\quad 60$

$\begin{array}{ll}3.4 .1 & \text { Methodological structure }\end{array}$

3.4.2 Input data for new sectors $\quad 62$

3.4.3 Model aggregation and scenario implementation $\quad 65$

4.1 Bottom-up MARKAL-NL-UU projections $\quad 68$

$\begin{array}{lll}4.1 .1 & \text { Final energy use } & 68\end{array}$

4.1.2 Electricity technology mix $\quad 70$

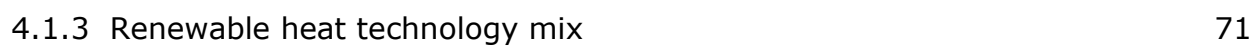

4.1.4 Transport technology mix $\quad 72$

4.1.5 Chemical technology mix $\quad 74$

$\begin{array}{ll}\text { 4.1.6 Demand for biomass } & 76\end{array}$ 
4.1.7 $\mathrm{CO}_{2}$ emissions

$\begin{array}{lll}4.2 & \text { Top-down MAGNET projections } & 87\end{array}$

4.2.1 GDP and sectoral value added (in $€$ billions) 88

4.2.2 Employment $\quad 92$

4.2.3 Biomass use in transport, electricity and chemical sectors 93

4.2.4 Biomass supply 98

4.2.5 Trade balance $\quad 99$

4.2.6 $\mathrm{CO}_{2}$ emissions $\quad 102$

4.3 Comparison between the bottom-up and the top-down analyses 103

$\begin{array}{ll}\text { 4.3.1 End use of biomass } & 104\end{array}$

$\begin{array}{ll}\text { 4.3.2 Biomass supply } & 106\end{array}$

4.4 Bioeconomy in Dutch provinces in $2030 \quad 106$

4.4.1 Building regional bioeconomy strategies 106

4.4.2 Building regional bioeconomy clusters 107

$\begin{array}{ll}4.4 .3 \text { Bioeconomy in Dutch provinces } & 110\end{array}$

5.1 Bottom-up MARKAL-NL-UU projections 113

5.1.1 Fossil fuel prices 113

$\begin{array}{ll}5.1 .2 \text { Biogas } & 115\end{array}$

$\begin{array}{ll}5.1 .3 \mathrm{CO}_{2} \text { emission scenarios } & 117\end{array}$

$\begin{array}{ll}5.1 .4 \text { Aviation } & 119\end{array}$

5.1.5 Reduced demand for chemicals $\quad 121$

5.2 Top-down MAGNET sensitivity analyses 122

5.2.1 Fossil fuel prices $\quad 122$

5.2.2 $\mathrm{CO}_{2}$ tax and emission reduction targets $\quad 124$

5.2.3 Higher technological change in agriculture $\quad 126$

$\begin{array}{ll}5.2 .4 & \text { Lower sugar prices } \\ & 129\end{array}$

$\begin{array}{lrr}6 & \text { Discussion } & 131\end{array}$

$\begin{array}{lll}6.1 & \text { Outcome compared to MEV-I } & 131\end{array}$

6.2 Scenarios and scope 132

6.3 Impact of policies and level playing field 133

6.4 Feedstock supply potential and sustainability 133

$\begin{array}{ll}6.5 & 135\end{array}$

7.1 Conclusions on impacts at the system level 137

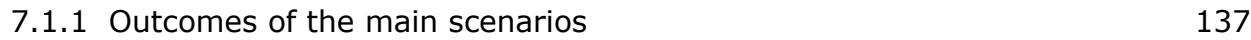

7.1.2 Outcomes of sensitivity analysis and additional scenarios $\quad 139$

7.2 Conclusions on impacts at the macroeconomic level 140

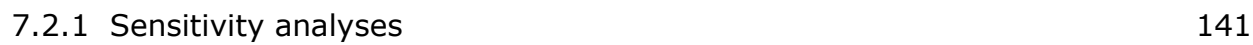

$\begin{array}{lll}7.3 & \text { Future research } & 142\end{array}$

$\begin{array}{ll}\text { References and websites } & 144\end{array}$

$\begin{array}{lll}\text { Appendix } 1 & \text { MEV I scenarios in the } 2009 \text { study } & 148\end{array}$

Appendix 2 Input data MARKAL-NL-UU $\quad 149$ 


\section{Preface}

This macroeconomic impact assessment shows that large-scale deployment of biomass up to 2030 positively contributes to the Dutch economy, contributes to meeting the emission reduction targets and elevates part of the costs that result from achieving greenhouse gas emission reduction targets. High technological change and global markets with low biomass prices enable these impacts. To achieve the positive macroeconomic impacts and emission reduction targeted climate change, renewable energy and R\&D policies are necessary.

This macroeconomic impact assessment study conducted in 2014-2015 is a follow-up and much extended version of the first study and is commissioned by the topsector platform for knowledge development and innovation of the cross-cutting theme bio-based economy (TKI-BBE) and the Dutch Ministry of Economic Affairs (Min EZ). This study to assess the macroeconomic impact of large-scale deployment of biomass for energy and biorenewables in the Netherlands is commissioned to LEI Wageningen UR and the Copernicus Institute of Utrecht University. The study is performed within the BE-Basic R\&D programme. Two model approaches were applied based on a consistent set of scenario assumptions: a bottom-up study including techno-economic projections of fossil and bio-based conversion technologies and a top-down study including macroeconomic modelling of (global) trade of biomass and fossil resources. Information on cost structures, break-even points, technical progress (learning effects) and substitution possibilities of the firms was crucial for determining the macroeconomic impact. The project partners Essent, DSM and Corbion provided in-kind contributions to the economic and technical aspects of the work.

The methods and outcomes have been extensively discussed with project partners and other stakeholders. Most importantly the authors want to thank the industrial project partners (Essent, DSM, Corbion and BioBasedActivities), BE-Basic, Top sector consortium for knowledge and innovation of the bioeconomy (TKI-BBE), University of Delft, Wageningen University and Research Centrum, University of Groningen, Dutch Sustainable Biomass Commission (Corbey), Avantium, ECN, Food and Biobased Research (FBR Wageningen UR), Havenbedrijf Rotterdam, Rabobank, Akzo Nobel, the Ministry of Economic Affairs, and the Ministry of Infrastructure and Environment for their comments, discussions and time spent during the various project and stakeholder events.

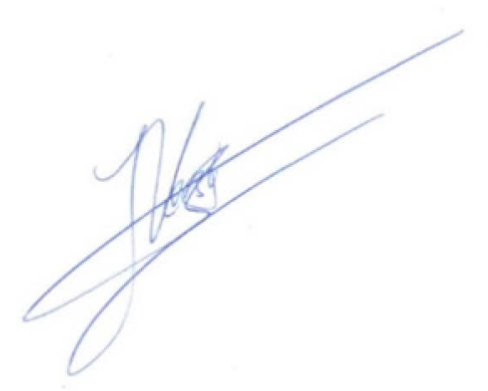

Prof.dr.ir. Jack G.A.J. van der Vorst

General Director Social Sciences Group - Wageningen UR 


\section{Summary}

The transition from a fossil-based economy to a bioeconomy contributes to reduce the dependency on fossil fuels, to meet our greenhouse gas emission reduction targets, and strengthen the Dutch economy. This macroeconomic assessment of large-scale deployment of biomass to 2030 shows that a bioeconomy can positively contribute to the Dutch economy, contributes to achieving the emission reduction targets and elevates part of the cost of achieving the overall emission reduction targets. High technological change and global markets with low biomass prices are important to achieve these impacts. The economic impact is very much related to volatile fossil energy prices. Low fossil energy prices reduce the macroeconomic benefits but the contributions of the bioeconomy to emission reduction remain. To achieve the positive macroeconomic impacts and emission reduction a stimulus by policies (e.g. $\mathrm{CO}_{2}$ taxes, $\mathrm{R} \& D$ policies) is necessary.

\section{Introduction}

To meet the emission targets, the Dutch government expects that a large-scale deployment of biomass is needed (Min EZ, 2015). This raises the question which macroeconomic impacts such a deployment of biomass will have on the Dutch economy. This study analyses the impacts of the biobased economy at both system and macroeconomic levels. System-level impacts include renewable energy deployment, fossil fuel reduction, and greenhouse gas (GHG) mitigation. Impacts at the macroeconomic level include gross domestic product (GDP), value added, employment and trade balance. In the MEV II study four main scenarios to 2030 are considered and a set of sensitivity scenarios is carried out. This study was commissioned by the Dutch Ministry of Economic Affairs (Min EZ) and the top-sector platform for knowledge development and innovation of the cross-cutting theme biobased economy (TKI-BBE) in the Netherlands.

\section{Current status of the Dutch bioeconomy in 2013}

The total primary energy supply of the Netherlands is dominated by fossil fuel use, primarily for the energy sectors (electricity, heat, fuels). A significant amount of fossil energy is used for non-energy purposes (about $25 \%$ of final consumption). Renewable energy use was $4.5 \%$ of the total energy use in 2013, which is far from the 14\% target for the Netherlands by 2020 based on the EU's renewable energy directive.

Final consumption of biomass increased from $42 \mathrm{PJ}_{\text {final }}$ in 2005 to almost $70 \mathrm{PJ}_{\text {final }}$ in 2013. Biofuels, biomass co-firing, organic fraction of municipal waste incineration and biomass combustion in wood stoves for heating were the most important applications. In 2013, 50\% of the final consumption of biomass was used for heat, approximately $31 \%$ for electricity, and the remaining $19 \%$ for transport fuels. Installed capacity of bioethanol was 422 kton, biodiesel was 761 kton and biopolymers was 140 kton in 2011.

In 2013 , the bioeconomy sectors contributed $7.7 \%$ to national turnover, $4.9 \%$ to national value added and national employment. With a share of 80 to $85 \%$ in the total bio-based economy in all these three categories, the contribution of the primary, food and feed sectors was dominant. Wood, paper and textile accounted for $10 \%$ and new, energy-intensive and labour-extensive, bio-based sectors (bioelectricity, bio-based chemicals, biofuels) contributed about 5\%. Multiplier effects for chemicals and energy are relatively high ( $>2$ ), meaning that the production of chemical or energy products generates relatively more additional activities (which are not per definition bio-based) in the rest of the economy than other bio-based sectors. Including these indirect effects the bioeconomy adds $12 \%$ to the turnover and $10 \%$ to both value added and employment of the Dutch economy. 


\section{The 4 MEV II Scenarios}

Four scenarios (RegLowTech, RegHighTech, GlobLowTech, GlobHighTech) to 2030 are developed over two axes of uncertainty: the rate of technological development of bio-based technologies and the availability of biomass from extra-EU source regions.

\section{Intra and extra European trade}

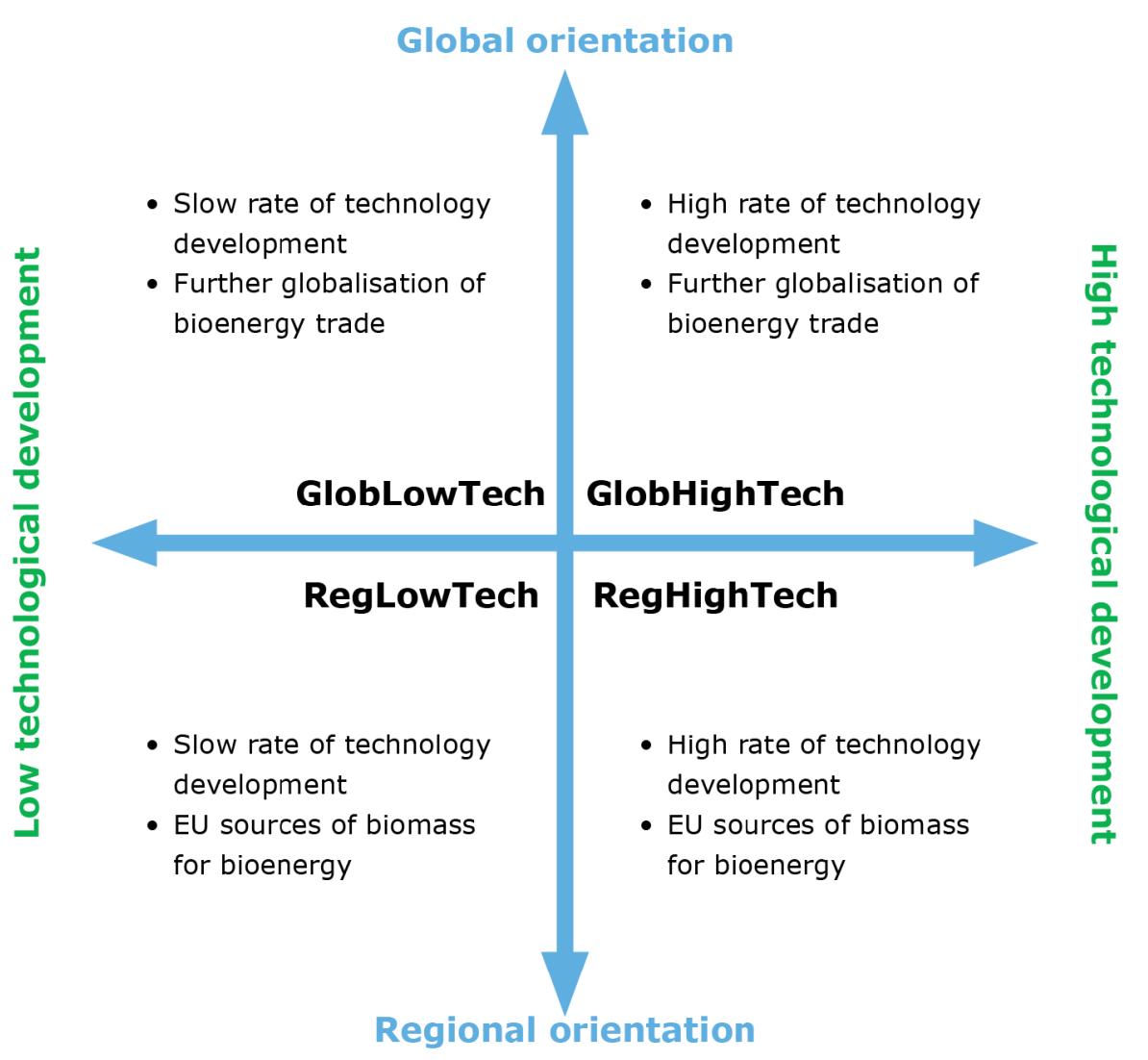

Intra European trade

Figure S.1 Four scenarios in MEV II

MEV II looked at technological improvements (e.g. on process efficiency) and the upscaling of technologies, which are expected to reduce production costs for energy and chemicals. However, this will depend on various factors, such as R\&D efforts or stimulating policies, and poses high uncertainties regarding different development pathways. . The LowTech scenario variants take into account technologies that are available today and moderate scale-up to already installed or announced capacities. The rate of incremental improvements in process yields and autonomous efficiency improvements is conservative. The HighTech scenario variants assume the implementation of both more technologies and higher scale technologies. The rate of incremental improvements in process yields and autonomous efficiency improvements is more optimistic.

The Reg(ional) and Glob(al) scenarios analyse the impact of restricted supply of biomass from only domestic EU28 production versus open trade and supply of solid biomass, liquid biofuels and other feedstocks from both inside and outside the EU28. A counterfactual ('NoBioBased') scenario is designed in which the production of new bio-based sectors (bioenergy, biofuels, bio-based chemicals) is not supported by policies or technological developments in order to assess the macroeconomic impact of bio-based technologies. Additional sensitivity analyses are carried out for low and high fossil fuel prices and $\mathrm{CO}_{2}$ policies (higher levels of $\mathrm{CO}_{2}$ tax, $\mathrm{CO}_{2}$ emission cap). Sector-specific support (e.g. biogas, ) and chemical demand scenarios are additionally analysed at the system level, whereas agricultural productivity and sugar scenarios are analysed at the macroeconomic level. 
The key macroeconomic and policy assumptions are given in the box below (BOX 1).

\section{BOX 1 Key macroeconomic and policy assumptions of MEVII}

- GDP and population growth are based on the Shared Socioeconomic Pathway 2 (SSP2) scenario of the IPCC (O'Neill et al., 2015).

- Crude oil price is €90/barrel in 2030 (IEA, WEO, 2014).

- Renewable energy share in the final energy demand for electricity, heat and transport fuels is $14 \%$ by 2020 and $16 \%$ by 2023 (Dutch Energy Agreement). Deployment of wind and solar energy is supported and biomass co-firing is limited to a maximum of $25 \mathrm{PJ}$ final energy. It is assumed that all energy policies are continued until 2030.

- Road transport biofuel share is $10 \%$ of total fuel use in transport based on EU RED in 2020 and is assumed to be extended to 2030 (double counting of $2^{\text {nd }}$ generation biofuels is included).

- $\mathrm{CO}_{2}$ tax is $€ 26 /$ tonne of $\mathrm{CO}_{2}$ in the $\mathrm{EU}$ in 2030 (IEA, 2014). These $\mathrm{CO}_{2}$ taxes apply to emissions from all sectors.

\section{Method}

The method of this MEV II study builds on the methodology of the first macroeconomic impact assessment study (MEV I) that was carried out in 2009 (Hoefnagels et al., 2009, 2013). MEV-I used a spreadsheet tool to calculate bottom-up scenarios. In MEV II, the cost optimisation MARKet ALocation (MARKAL-NL-UU) model (for energy and chemical industry sectors) is used as a bottom-up model. MARKAL is adjusted to include emerging bio-based economy sectors and integrates these with the energy system. Within MARKAL, multi-output processes are modelled and the model is able to demonstrate cross-sectoral synergy. An advanced version of the global Modular Applied GeNeral Equilibrium Tool (MAGNET) is used as a top-down model. It covers the whole economy and is adjusted with many biomass-producing sectors, disaggregated bio-based transport, electricity and chemical sectors and disaggregated fossil-based and renewable sectors. MAGNET is able to demonstrate the links of the emerging bioeconomy with the rest of the economy, including use of production factors and trade with the rest of the world.

\section{The bioeconomy by 2030}

Electricity is projected to become the largest renewable energy sector, which supplies more than $50 \%$ of the renewable energy supply by 2030 . This is primarily due to large investments in on- and offshore wind capacity, which is based on the Dutch Energy Agreement as planned between 2015-2019. Wind supplies more than $40 \%$ of renewable electricity output by 2030 (or approximately $120 \mathrm{PJ}_{\mathrm{e}}$ ) and is constant across all scenarios. Heat and transport fuels cover the remaining demand for renewable energy, where biomass is the only resource used. The sizes of the different sectors are bioelectricity ( $\sim 4-7 \%$ of the total renewable energy output), biomass heat ( $30-40 \%)$ and biofuels $(\sim 10-20 \%)$.

Table S.1

Summary of key results for the 4 scenarios from MARKAL-NL-UU/bottom-up model/at systems level

\begin{tabular}{|c|c|c|c|c|c|}
\hline & \multirow[t]{2}{*}{2010} & \multicolumn{4}{|c|}{2030} \\
\hline & & RegLowTech & GlobLowTech & RegHighTech & GlobHighTech \\
\hline \multicolumn{6}{|c|}{ Primary energy $[\mathrm{PJ}]$} \\
\hline Biomass & 133 & 233 & 224 & 289 & 345 \\
\hline \multicolumn{6}{|c|}{ Final consumption $[\mathrm{PJ}]$} \\
\hline Energy & 1,579 & 1,479 & 1,478 & 1,480 & 1,458 \\
\hline Non-energy & 484 & 612 & 606 & 581 & 521 \\
\hline \multicolumn{6}{|l|}{ Biomass } \\
\hline Energy & 62 & 145 & 148 & 145 & 167 \\
\hline
\end{tabular}


Technological development steers the end-uses of biomass. In the HighTech scenarios, production of biofuels switches from first generation biofuels to second generation biofuels. In the LowTtech scenarios mostly first generation biofuels are used. Advanced thermo-chemical biorefineries convert large amounts of lignocellulose to FT-fuels, exceeding the RED biofuel blending mandate of $10 \%$ in the high technological development scenarios.

In the HighTech scenarios, bio-chemical biorefineries convert large amounts of lignocellulosic biomass to fermentable sugar and/or ethanol, which to a large extent are used as feedstocks for the chemical sector. In the HighTech scenarios the contribution of the chemical sector to total renewable energy production (energy and non-energy) becomes increasingly important. Biomass remains the largest source of renewable energy (supplies up to $55 \%$ of total final renewable energy) and covers above $10 \%$ of the demand for chemicals by 2030 .

\section{Macroeconomic impact}

Given the macroeconomic and policy assumptions the large-scale deployment of biomass might have a positive impact on the value added of the Dutch economy in the medium term (2030). Across all scenarios only RegLowTech still has a negative GDP effect of $-€ 0.2 b n$ in 2030 (Figure S.2). Open markets and investments in technology development lead to a positive GDP effect of $€ 0.8 \mathrm{bn}$ annually in 2030 (GlobHighTech scenario). High technology developments and global markets add up to $€ 1 \mathrm{bn}$ to GDP on a yearly basis from 2030 onwards.

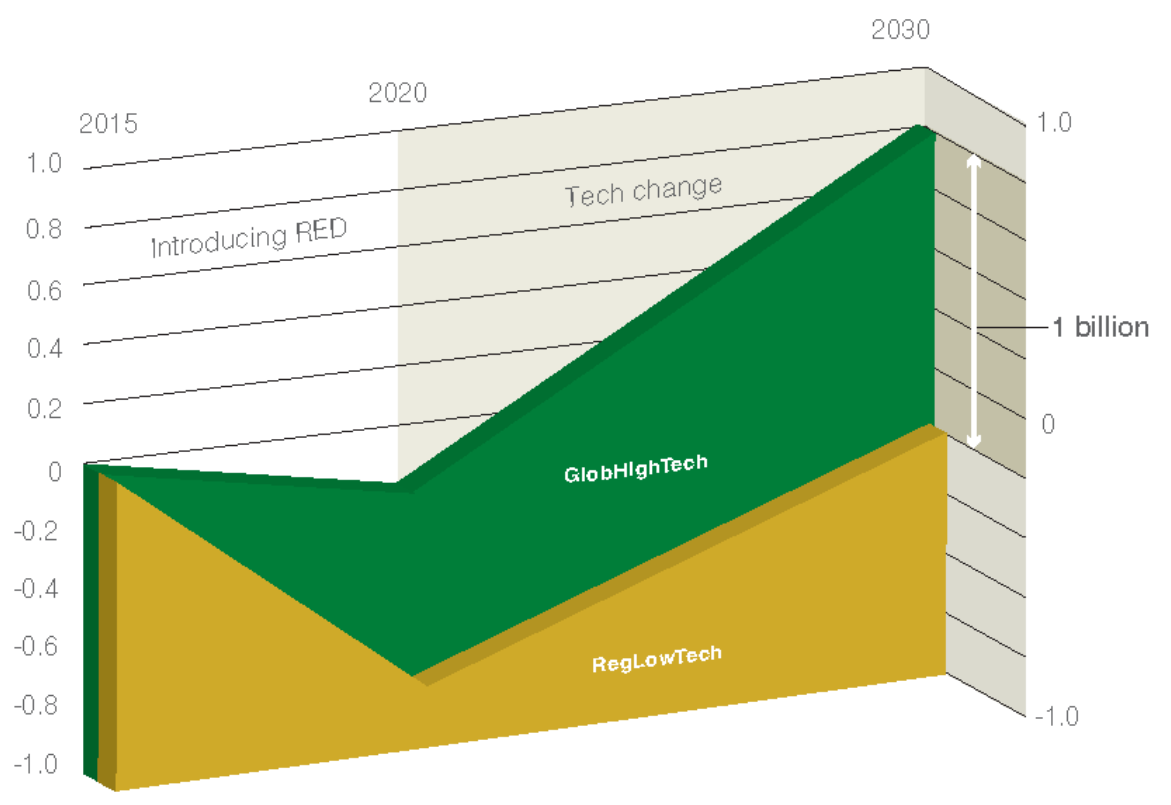

Figure S.2 GDP impact of RegLowTech and GlobHightech scenarios relative to NoBioBased scenario (absolute difference, $€$ billions).

In the 2015-2020 period, the main effect is the compliance with the renewable energy targets (RED) which leads to negative GDP effects in all scenarios in 2020 compared to a NoBioBased scenario as bioenergy technologies are not competitive to their fossil substitutes. The negative effect is stronger in the regional scenarios (-€0.8bn, see, 'RED + Regional' red arrow) than in the global scenarios ($€ 0.2 b n$, see 'RED + Global' blue arrow) as the EU cannot import (relatively cheap) biofuels from South and North America. The positive effect of technology advances becomes visible in the 2020-2030 period and is larger for HighTech ( $€ 1$ bn annually, see 'High Tech' blue arrow) than LowTech ( $€ 0.6 \mathrm{bn}$ annually, see 'Low Tech' red arrow) scenarios.

Within the bioeconomy, agriculture is a key sector in terms of value added. Its value added decreases slightly (by $-€ 160 \mathrm{~m}$ ) between 2015 and 2030 in the NoBioBased scenarios. In all four MEV II scenarios 
the agricultural value added in the Netherlands increases due to the emergence of a broader bioeconomy. The value added in the biochemical sectors increases by $€ 130 \mathrm{~m}$ in the LowTech scenarios and by $€ 250 \mathrm{~m}$ in the HighTech scenarios (compared to a NoBioBased scenario in 2030). The bioenergy use is largely driven by policies and the value added is fairly constant across the scenarios. Relative to the NoBioBased scenario the value added of bioenergy is about $€ 280 \mathrm{~m}$ higher in 2030.

In the NoBiobased scenario the employment in agriculture, bioenergy and biochemical sectors is lower in 2030 than in 2015 due to a decline of employment in agriculture which is in compliance with the long-term trend. The increase of the bio-based economy only partially mitigates this effect. The highest employment impacts come from the production of bio-based chemicals in the case of the HighTech scenarios and to a smaller extent in the GlobLowTech scenario.

\section{Production value}

The production value (similar to turnover) of the new bioeconomy sectors in 2030 more than doubles, from about $€ 1.7 \mathrm{bn}$ in the LowTech to almost $€ 4 \mathrm{bn}$ in the HighTech scenarios. Bioenergy production is rather stable at $9 \%$ of total energy production and equal to almost $€ 0.6 \mathrm{bn}$. Growth especially takes place in the production of biofuels and new bio-based chemicals as production increases from about $€ 0.4 \mathrm{bn}$ and $€ 0.7 \mathrm{bn}$ in the LowTech scenarios to $€ 1.2 \mathrm{bn}$ and $€ 2 \mathrm{bn}$ in the HighTech scenarios. The new bio-based chemical production adds $1 \%$ to the overall chemical production in the LowTech scenarios and $4 \%$ in the HighTech scenarios, and partly limits the negative trend $(-10 \%)$ in chemical production.

\section{Biomass demand}

The new bio-economy needs significantly more biomass compared to 2015. Figure S.3 shows the biomass demand in 2010 and 2030. Biomass demand in 2030 ranges from 224 PJ to 345 PJ, which demonstrates the dependence of the bio-based economy on technology development and on the availability and price of biomass. Forestry products and residues and wood from short-rotation forestry supply more than $50 \%$ of total biomass consumed, which are partially imported as wood pellets from outside the EU28. Bio- and thermo-chemical biorefineries consume up to $154 \mathrm{PJ}$ biomass in approximately equal shares.
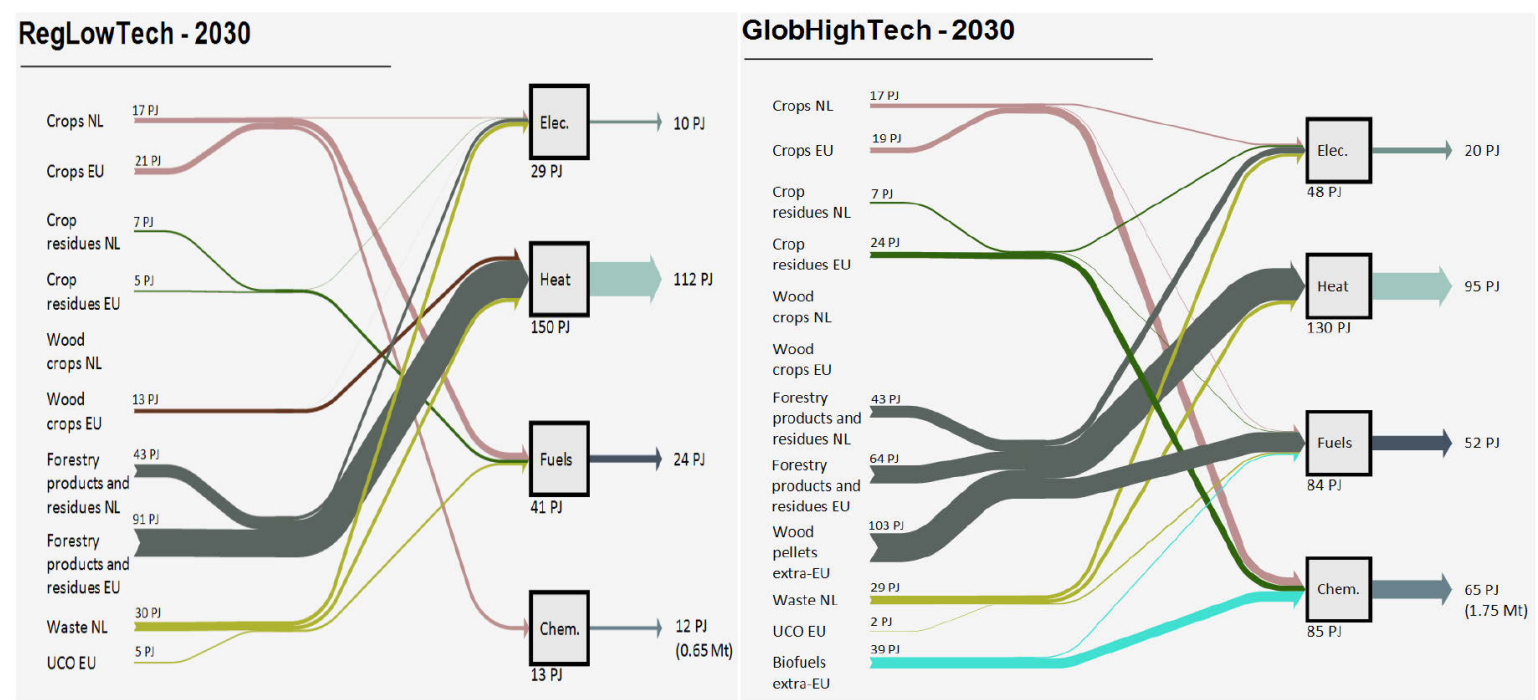

Figure S. $\mathbf{3}^{1}$ Biomass flows for Regional Low Tech and Global High tech scenarios

\section{Trade balance}

The imports of biomass and the replacement of fossil fuels have an impact on the trade balance. In the short run (up to 2020), the total trade balance in the Netherlands is projected to deteriorate in the bio-based economy scenarios relative to the NoBiobased scenario. The negative impact is caused by

\footnotetext{
1 Wood pellet equivalent $=17.1 \mathrm{PJ}$ per $\mathrm{mt}$ of dry biomass
} 
the introduction of the renewable energy targets (RED), which requires substitution of fossil technologies with more costly bio-based technologies. The fossil and total energy trade balance improves, but this is more than offset by increased biomass imports and especially a deterioration of the trade balance of other industries and services. However, after 2020 bio-based technologies become more efficient and Dutch export of second generation biofuels and especially bio-based chemicals increases. This reduces the overall decline of the trade balance. In the LowTech scenarios, fossil energy is substituted by first generation biofuels, but as part of these are produced domestically, the energy trade balance improves. In the HighTech scenarios the production of bio-based and conventional fuel and chemicals increase and result in higher exports, which limits the reduction of fossil energy imports and use. However, the exports of bio-based products substitute fossil energy use and reduce GHG emissions in other countries.

\section{Greenhouse gas emissions}

Under the existing energy policies and moderate $\mathrm{CO}_{2}$ tax (see Box 1), and despite the large increase of renewable energy from wind and biomass, emissions stabilize at 2010 levels which is far from the ambition levels of $40 \%$ reduction by 2030 Reduction is mainly achieved by the electricity and industry sectors. The use of regional and global biomass decreases emissions by $1-3 \%$ in the bottom-up analyses.

\section{Sensitivity results}

The results presented above are highly sensitive to climate policies, fossil fuel and feedstock prices. Sensitivity analyses have been conducted to determine the impact of different assumptions on the system and macroeconomic impacts due to the emergence of the bio-economy.

High $\mathrm{CO}_{2}$ tax

A high $\mathrm{CO}_{2} \operatorname{tax}\left(€ 71 / \mathrm{tCO}_{2}\right)$ can lead to a significant emission decrease (approximately $35 \%$ compared to 1990). Such tax levels increase the biomass consumption in the energy system by a factor two compared to the reference scenarios, they stimulate wind energy deployment beyond the ambition levels of the Dutch Energy Agreement, and require mitigation technologies such as Carbon Capture and Storage (CCS) and bioenergy with CCS (BECCS). In addition, efficiency improvements in the transport vehicle fleet are required, which can be realized by hybrid vehicles.

The realisation of high $\mathrm{CO}_{2}$ reductions within Netherlands comes at a price. To reach the $40 \%$ emission reduction within the Netherlands, GDP declines by more than $€ 8 b n$ ( $1 \%$ of GDP) in the NoBioBased scenario relative to the main NoBioBased scenario which was only characterized by a $\mathrm{CO}_{2}$ price of $€ 26 / \mathrm{tCO}_{2}$. If biomass markets are global and especially if technological change is higher in bio-based technologies, as assumed in the GlobHighTech scenario, these costs to GDP can be reduced to $€ 5 \mathrm{bn}$ ( $0.6 \%$ of GDP). High technology progress and further opening of global biomass markets are therefore a prerequisite to achieve 40\% emission reduction compared to 1990 .

\section{Fossil prices}

The deployment of large-scale of biomass conversion technologies is largely steered by fossil fuel prices. A $50 \%$ increase of fossil fuel prices shoots biomass consumption to two thirds of the available potential (770 PJ out of approximately $1 \mathrm{EJ}$ ) with increased supply in sectors such as biofuels and biobased chemicals, and wind in electricity.

Lower fossil energy prices ( $€ 45$ per barrel oil) increase the Dutch GDP and also GHG emissions. Under these conditions the bio-based economy depends on policies, because bio-based technologies are not cost-competitive and biomass is only used to meet the binding national target of the RED ( $14 \%$ by 2020). The bio-based chemicals production will almost disappear. A high technological change only implies that the first generation biofuels are substituted by second generation technologies.

Introducing a bio-based economy in a context of low fossil fuel prices is costly and resulting in a $€ 2$ bn GDP loss in the RegLowTech scenario versus the NoBiobased scenario (see, Figure S.4). Open markets and high technological change in bio-based technologies reduce this negative impact on GDP to $€ 400 \mathrm{~m}$. 


\section{Other bio-based technologies}

Under the reference scenarios, manure treatment and subsequent conversion to biogas is not found cost-effective. In a sensitivity scenario, which mandatory manure treatment, biomass consumption increases significantly to 480-600 PJ, primarily due to large quantities of co-digestate (energy maize) that is required. The use of solid biomass for heat in the four reference scenarios is then largely replaced by green gas from manure treatment. The production of bio-based jet fuels was also assessed as an additional scenario. Results show that bio-jet fuels start to become cost-competitive only by 2030 and only under GlobHighTech scenario assumptions.

\section{Feedstock prices}

The main scenarios assume no additional technological change in the primary sectors. Higher yields in the primary sectors such as agriculture and forestry lead to significant positive GDP effects as especially the export oriented agri-food industries can increase their market share without having to decrease their price levels too much. The GDP impact of a $10 \%$ yield increase is substantial $(0.3 \%$ of GDP). The indirect benefits for the new bio-based economy sectors are limited as they source only a small share from domestic agricultural primary products. Higher yields in the sugar beet sector and lower sugar prices increase value added with $€ 34 \mathrm{~m}$ in the bio-based economy and especially the sugar sector. The lower sugar price also increases the value added of bio-based chemicals $(€ 5-8 \mathrm{~m}$, especially from PLA production) and to a lesser extend biofuels.

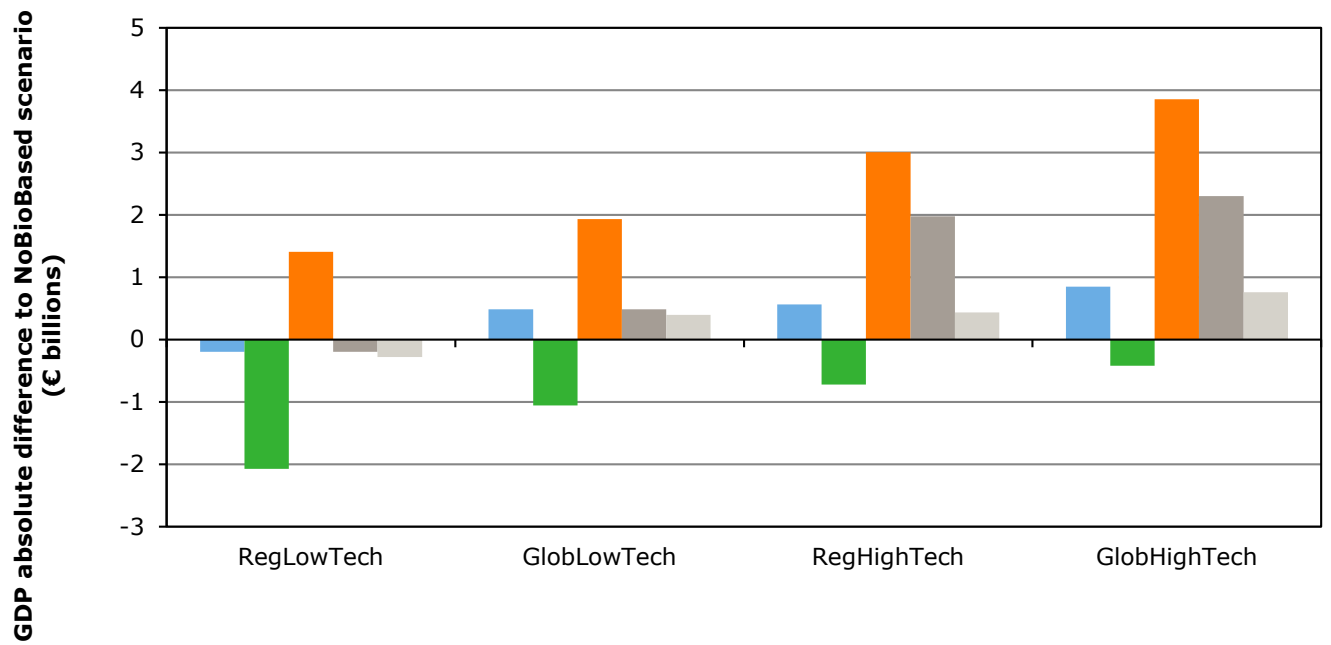

main $\quad$ low fossil price $\quad$ emission reduction $\quad$ high yields agriculture $\quad$ high sugar yields

Figure S.4 GDP impact, absolute differences to NoBioBased scenario (bln euro).

Figure S. 4 provides a summary of the sensitivity analyses on the macro-economic (GDP) impact of the emergence of a bioeconomy. The analyses shows that the macroeconomic impact is negatively affected by low fossil energy prices and positively by renewable energy policies and yield effects in the agricultural sectors.

\section{Comparison with MEV I}

The economic impact of the bio-economy in the four scenarios considered in the MEV II study, is smaller compared to the MEV I study. Key reasons for this are:

i. Technology progress in- and outside the Netherlands has developed according to a 'LowTech' scenario pathway over the last 5 years. This entails that in the MEV II study the development of bio-based technologies is delayed compared to assumptions made in the MEV I study for 2015.

ii. Ambitions for biomass deployment are more realistic in MEV II compared to MEV I in which up to $30 \%$ of primary energy supply in the Netherlands was projected to be supplied from biomass in 2030. 
iii. The current study looks more extensively at the competition with other renewable energy sources (mainly wind and PV) and includes, in contrast to MEV I, the option of carbon capture and storage (CCS). This leads to more balanced deployment pathways of renewable energy compared to the pre-defined biomass technology deployment scenarios of MEV I.

Although the magnitude of biomass deployment for energy and materials is different between the MEV I and II, both studies show that the use of biomass for energy and chemicals can have positive synergetic effects on reducing GHG emissions, energy security and generate economic activities in agriculture, chemical and energy sectors of the Netherlands. The preconditions to achieve these synergetic effects are similar in both studies and include:

i. The need for strong technology development and availability of international sustainable biomass sources at attractive prices.

ii. A shift from food-based production to non-food lignocellulosic feedstocks

iii. Accelerated development of efficient production systems, in particular multi-output biorefineries that produce energy (electricity, heat, transport fuels) and chemicals both via thermo- and biochemical conversion routes.

\section{Conclusions}

To conclude, in order to meet short-term renewable energy targets and the greenhouse gas reduction targets of the Dutch energy and non-energy system the results of this study suggests that:

- The bioeconomy can positively contribute to the Dutch economy and to achieving the emission reduction targets, and can limit the costs of realising these emission reduction targets.

- Positive macroeconomic impacts of the bio-based economy depend on (i) a high rate of technological change, (ii) high fossil energy prices, (iii) global trade system, and (iv) low biomass prices. A biobased economy driven by high technological change and high availability of low cost biomass reduces the macroeconomic costs of mitigation options and makes bio-based options less costly with low fossil energy prices

- To achieve these positive macroeconomic and emission impacts a stimulus by policies in the short term is necessary:

- Heat from biomass and wind electricity (supported by Dutch policy) can contribute significantly to the renewable energy targets

- High technology development in bio-based sectors is required to make bio-energy and biochemical cost competitive. Biorefineries may have a key role as they create synergies across multiple sectors

- A high $\mathrm{CO}_{2}$ tax has a strong influence as a policy instrument

- CCS and bECCS are important mitigation options to meet $\mathrm{CO}_{2}$ reduction targets in case of very ambitious climate change policies (e.g. the Paris Agreement) as there are no other cost-effective alternatives in the narrow time-frame of the study

- Low feedstock prices and access to international biomass resources is required and therefore development of stable international biomass markets is needed

- Investments in technological change in the agricultural sectors (e.g. sugar yields) can contribute to a growing bio-based economy and a positive trade balance.

\section{Future research}

The MEV II study has been designed on the basis of a midterm temporal scope (2030) and large-scale deployment potential for biomass conversion technologies across different sectors. An outlook for the longer term (e.g., 2040, 2050) will most likely vary from what is presented for 2030. Therefore, we recommend for further research to extend the temporal scope to a longer term analysis (e.g., 2040, 2050) in which technological learning and economies of scale may result in a larger role for biomass due to improved cost competitiveness of technologies, higher $\mathrm{CO}_{2}$ prices, etc. New and more advanced alternative renewable energy sources and substitutes for materials will become available. This is particularly relevant for biomass conversion technologies to chemicals where advanced routes may have significant impact (e.g., lignin valorization to high value products). Finally, a study that assesses a longer-term goal should not only focus on bulk replacement of fossil fuels, but also on high value/low volume products (e.g. specialty chemicals). Despite that such routes may not have significant role in bridging emission reduction gaps or in substituting large volumes of fossil fuels, they may demonstrate a high impact of bio-based economy in terms of value added and employment. 
Inevitably, the uncertainties related to longer term projections also increases, which can be captures by scenario and sensitivity analyses. However, the results provide insight in which technologies might require support now to stimulate their deployment in the future. Key factors are economies of scale, synergies between technologies, e.g. the valorisation of side-streams, which are key for the returns for the Dutch economy. Finally, we advise to repeat this study every three years due to fast changing technologies and policies. 


\section{Samenvatting}

De overgang van een fossiele economie naar een bio-economie heeft als doel dat we minder afhankelijk worden van fossiele brandstoffen en dat de aan onze doelen voor klimaatverandering voldoen. Daarnaast is de overgang naar een bio-economie goed voor de Nederlandse economie. Uit macro-economisch onderzoek naar een grootschalig gebruik van biomassa voor energie en materialen blijkt dat de bio-economie positief kan bijdragen aan: de Nederlandse economie, het behalen van broeikasgasreductiedoelstellingen en de kosten van het terugdringen van broeikasgasemissies reduceert. Om deze effecten te realiseren, zijn grootschalige technologische veranderingen en wereldwijde markten met lage biomassaprijzen belangrijk. De macro-economische effecten zijn erg afhankelijk van de fossiele energieprijzen. Lage prijzen van fossiele energie leiden tot minder macroeconomische voordelen, maar de bijdrage van de bio-economie aan de $\mathrm{CO}_{2}$-reductie blijft onveranderd. Om de positieve macro-economische effecten en $\mathrm{CO}_{2}$-reductie te realiseren is een stimuleringsbeleid (bijvoorbeeld $\mathrm{CO}_{2}$-belastingen, $\mathrm{R} \& D$-beleid) noodzakelijk.

\section{Inleiding}

De Nederlandse overheid verwacht dat een grootschalige toepassing van biomassa nodig is om aan de emissiedoelstellingen te voldoen (Min EZ, 2015). Dit werpt de vraag op wat de macro-economische effecten zijn van het gebruik van biomassa op de Nederlandse economie. Deze studie onderzoekt de effecten van een bio-economie op zowel systeem- als macro-economisch niveau. Tot de effecten op systeemniveau behoren toepassing van hernieuwbare energie, reductie van het gebruik van fossiele brandstoffen en verlaging van de $\mathrm{CO}_{2}$-uitstoot. Tot de effecten op macro-economisch niveau behoren het Bruto Nationaal Product (BNP), de toegevoegde waarde, werkgelegenheid en handelsbalans. In het MEV-II-onderzoek worden vier hoofdscenario's tot 2030 en een reeks gevoeligheidsscenario's bekeken. Dit onderzoek is uitgevoerd in opdracht van het Nederlandse ministerie van Economische Zaken (Min EZ) en het Topconsortium voor Kennis en Innovatie voor de Biobased Economy (TKI-BBE) in Nederland.

\section{Status van de Nederlandse bio-economie in 2013}

De huidige primaire energievoorziening in Nederland wordt gedomineerd door het gebruik van fossiele brandstoffen, voornamelijk voor de energiesectoren (elektriciteit, verwarming, vervoer). Er wordt een aanzienlijke hoeveelheid fossiele energie gebruikt voor niet-energiedoeleinden (circa $25 \%$ van het eindverbruik). Het aandeel van hernieuwbare energie bedroeg 4,5\% van het totale eindverbruik van energie in 2013. Dit komt bij lange na niet in de buurt van de doelstelling van 14\% in 2020 die volgens de EU-Richtlijn Hernieuwbare Energie voor Nederland is gesteld.

Het eindverbruik van biomassa steeg van $42 \mathrm{PJ}_{\text {final }}$ in 2005 naar bijna $70 \mathrm{PJ}_{\text {final }}$ in 2013 . De belangrijkste toepassingen waren biobrandstoffen voor transport, meestoken van biomassa met kolen, verbranding van de organische fractie van stedelijk afval en de verbranding van biomassa in houtovens voor verwarming. In 2013 werd 50\% van het eindverbruik van biomassa gebruikt voor verwarming, circa 31\% voor elektriciteit en de resterende 19\% voor transportbrandstoffen. In 2011 bedroeg de geïnstalleerde capaciteit van bio-ethanol 422 kton, van biodiesel 761 kton en van biopolymeren 140 kton.

In 2013 leverden de bio-economiesectoren een bijdrage van 7,7\% aan de nationale omzet en 4,9\% aan de nationale toegevoegde waarde en nationale werkgelegenheid. Met een aandeel van 80 tot $85 \%$ in de totale bio-economie leverden de primaire sector, de sector voedingsmiddelen en de sector diervoeders de grootste bijdrage. Hout, papier en textiel waren goed voor $10 \%$ en nieuwe energie- en arbeidsintensieve biobased sectoren (bio-elektriciteit, biobased chemicaliën, biobrandstoffen) leverden een bijdrage van circa 5\%. De multiplier effecten voor chemicaliën en energie zijn relatief hoog $(>2)$. Dit betekent dat de productie van chemische producten of energieproducten relatief meer bijkomende activiteiten (die niet per definitie biobased zijn) in de rest van de economie genereert dan overige 
biobased sectoren. Wanneer deze indirecte effecten worden meegerekend, voegt de bio-economie $12 \%$ toe aan de omzet en $10 \%$ aan zowel de toegevoegde waarde als aan de werkgelegenheid binnen de Nederlandse economie.

\section{De 4 MEV-II-scenario's}

Vier scenario's (RegLowTech, RegHighTech, GlobLowTech, GlobHighTech) zijn op basis van twee onzekerheidsassen ontwikkeld voor de periode 2015-2030: het tempo van de technologische ontwikkeling van biobased technologieën en de beschikbaarheid van biomassabronnen uit regio's buiten de EU.

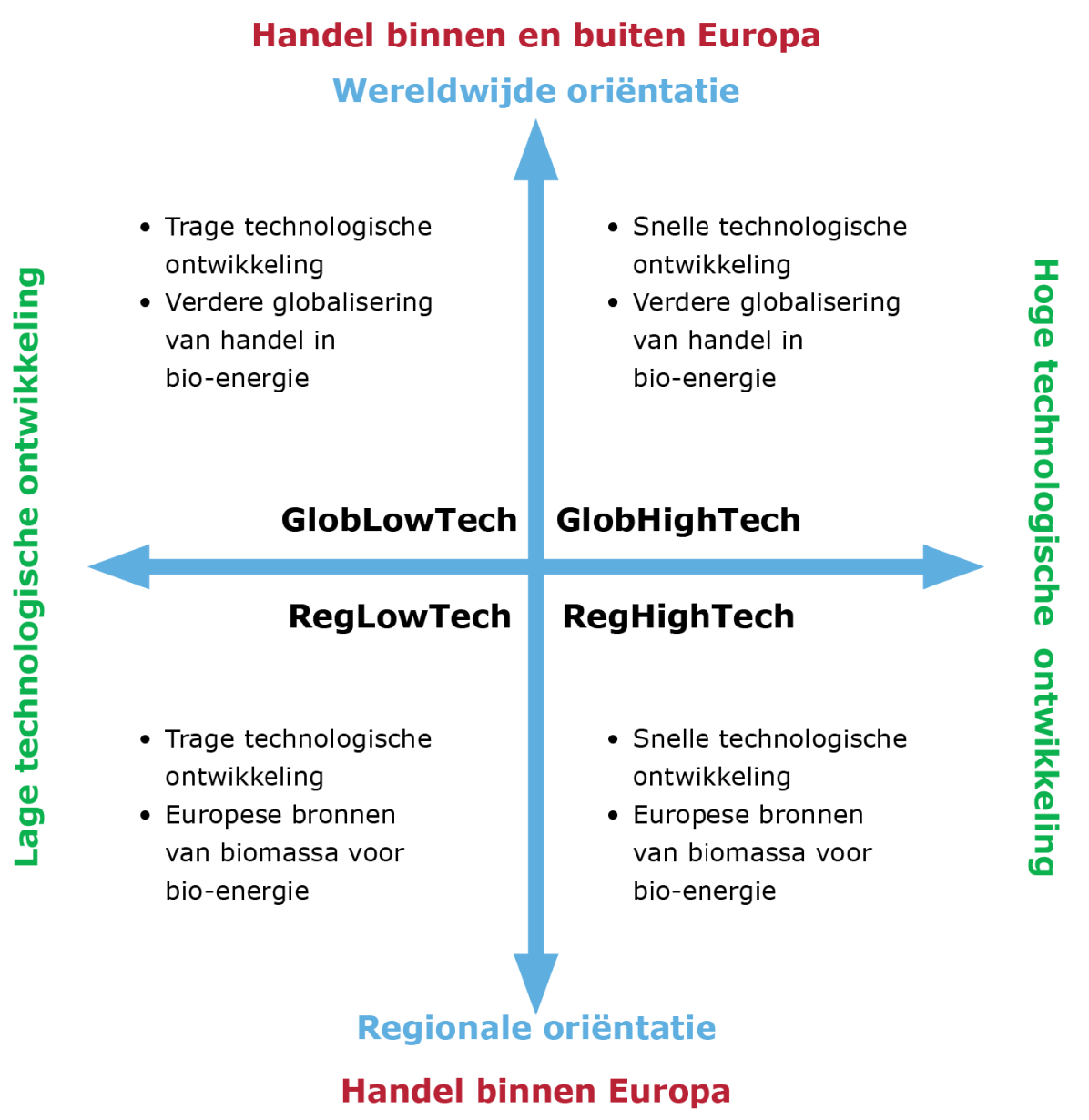

Figuur S.1 Vier scenario's in MEV-II

De MEVII-studie bekijkt technologische verbeteringen (onder andere procesefficiency) en de opschaling van technologieën, die met name kosten reduceren in de energie en chemische sectoren. Deze ontwikkeling is van vele factoren afhankelijk, zoals R\&D-inspanningen en stimulerend beleid, en brengt daardoor grote onzekerheden met betrekking tot technologische ontwikkelingspaden met zich mee. In het scenario met lage technologische ontwikkelingen (LowTech-scenario) worden alleen technologieën meegenomen die nu al beschikbaar zijn, waarbij een beperkte opschaling van al bestaande of geplande productiecapaciteit is meegenomen. Incrementele innovaties op onder andere procesgebied en autonome efficiencyverbeteringen zijn beperkt in dit scenario. De HighTech-variant veronderstelt de implementatie van zowel meerdere technologieën en een hoger schaalniveau. Incrementele innovaties op onder andere procesgebied en autonome efficiencyverbeteringen zijn optimistischer in dit scenario.

De Reg(ionale) en Glob(ale) scenario's analyseren het effect van een beperkte levering van biomassa uit uitsluitend binnenlandse EU28-productie versus de open handel en levering van vaste biomassa, vloeibare biobrandstoffen en overige feedstocks uit zowel binnen als buiten de EU28-landen. Er is een referentie ('NoBioBased'-)scenario ontworpen, waarin de productie van nieuwe biobased sectoren niet 
wordt gestimuleerd door beleid of technologische ontwikkeling om zo het macro-economische effect van biobased technologieën te kunnen beoordelen. Er worden aanvullende gevoeligheidsanalyses uitgevoerd voor lage en hoge prijzen van fossiele brandstof en $\mathrm{CO}_{2}$-beleidsmaatregelen (hogere belasting op $\mathrm{CO}_{2}, \mathrm{CO}_{2}$-emissieplafond). Daarnaast worden er sectorspecifieke

ondersteuningsscenario's (bijvoorbeeld biogas) en chemische vraagscenario's op systeemniveau geanalyseerd, terwijl er op macro-economisch niveau analyses van landbouwproductiviteits- en suikerscenario's worden uitgevoerd. In onderstaand venster (BOX 1) worden de belangrijkste aannames wat betreft macro-economie en beleid weergegeven.

BOX 1 Belangrijkste aannames wat betreft macro-economie en beleid van MEV-II

- De groei van het BNP en de bevolking zijn gebaseerd op het scenario 'Shared Socioeconomic Pathway 2' (SSP2) van het IPCC (O'Neill et al., 2015).

- De prijs van ruwe olie is $€ 90 / v a t$ in 2030 (IEA, WEO, 2014).

- Het aandeel hernieuwbare energie in de eindvraag naar elektriciteit, verwarming en vervoersbrandstoffen zal 14\% in 2020 en $16 \%$ in 2023 bedragen (SER Energieakkoord). Toepassing van wind- en zonne-energie wordt ondersteund en het meestoken van biomassa wordt beperkt tot maximaal $25 \mathrm{PJ}_{\text {final }}$ energie. Er wordt van uitgegaan dat alle energiebeleidsmaatregelen tot 2030 worden voortgezet.

- In 2020 bedraagt het aandeel biobrandstof voor wegvervoer $10 \%$ van het totale brandstofverbruik in het vervoer op basis van EU RED. Dit zal naar verwachting worden verlengd tot 2030 (dubbeltelling van tweede-generatie biobrandstoffen is hierin opgenomen).

- In 2030 bedraagt de $\mathrm{CO}_{2}$-belasting $€ 26 /$ ton $\mathrm{CO}_{2}$ binnen de $\mathrm{EU}$ (IEA, 2014). Deze $\mathrm{CO}_{2}$-belastingen gelden voor de uitstoot binnen alle sectoren.

\section{Methode}

De methode van dit MEV-II-onderzoek bouwt voort op die van het eerste beoordelingsonderzoek naar het macro-economische effect (MEV-I) dat in 2009 werd uitgevoerd (Hoefnagels et al. 2009, 2013). MEV-I maakte gebruik van spreadsheets om bottom-upscenario's te berekenen. In MEV-II wordt het model voor kostenoptimalisatie MARKet ALocation (MARKAL-NL-UU) (voor de sectoren energie en chemische industrie) als bottom-upmodel gebruikt. MARKAL is aangepast voor opkomende sectoren van de bio-economie en integreert deze met het energiesysteem. Binnen MARKAL worden multioutputprocessen gemodelleerd en aan de hand van het model worden sectoroverschrijdende synergiën aangetoond. Als top-downmodel wordt een geavanceerde versie van het wereldwijde Modular Applied GeNeral Equilibrium Tool (MAGNET) gebruikt. Deze tool bestrijkt de hele economie en is uitgebreid met diverse biomassaproducerende sectoren, biobased vervoers-, elektriciteits- en chemische sectoren en sectoren voor hernieuwbare energie en fossiele energie. Met MAGNET kan het verband tussen de opkomende bio-economie en de rest van de economie worden aangetoond, waaronder het gebruik van productiefactoren en handel met de rest van de wereld.

\section{De bio-economie in 2030}

Naar verwachting zal elektriciteit de grootste hernieuwbare bron van energie worden in 2030, met een aandeel van meer dan $50 \%$ van de totale productie van hernieuwbare energie. Dit is voornamelijk het gevolg van grote investeringen in on- en offshore windcapaciteit, zoals gepland in het SER Energieakkoord voor 2015-2019. Windenergie zal in 2030 meer dan 40\% van de hernieuwbare elektriciteit (oftewel circa $120 \mathrm{PJ}_{\mathrm{e}}$ ) leveren. Dit aandeel blijft constant binnen alle scenario's. De resterende vraag naar hernieuwbare energie bestaat uit verwarmings- en transportbrandstoffen, waarbij biomassa de enige gebruikte grondstof is. De diverse sectoren hebben de volgende omvang: bio-elektriciteit ( $\sim-7 \%$ van de totale hernieuwbare geleverde energie), vwarmte uit biomassa ( 30$40 \%$ ) en biobrandstoffen ( $10-20 \%)$. 
Tabel S.1

Samenvatting van belangrijkste resultaten voor de 4 scenario's uit MARKAL-NL-UU/bottomupmodel/op systeemniveau

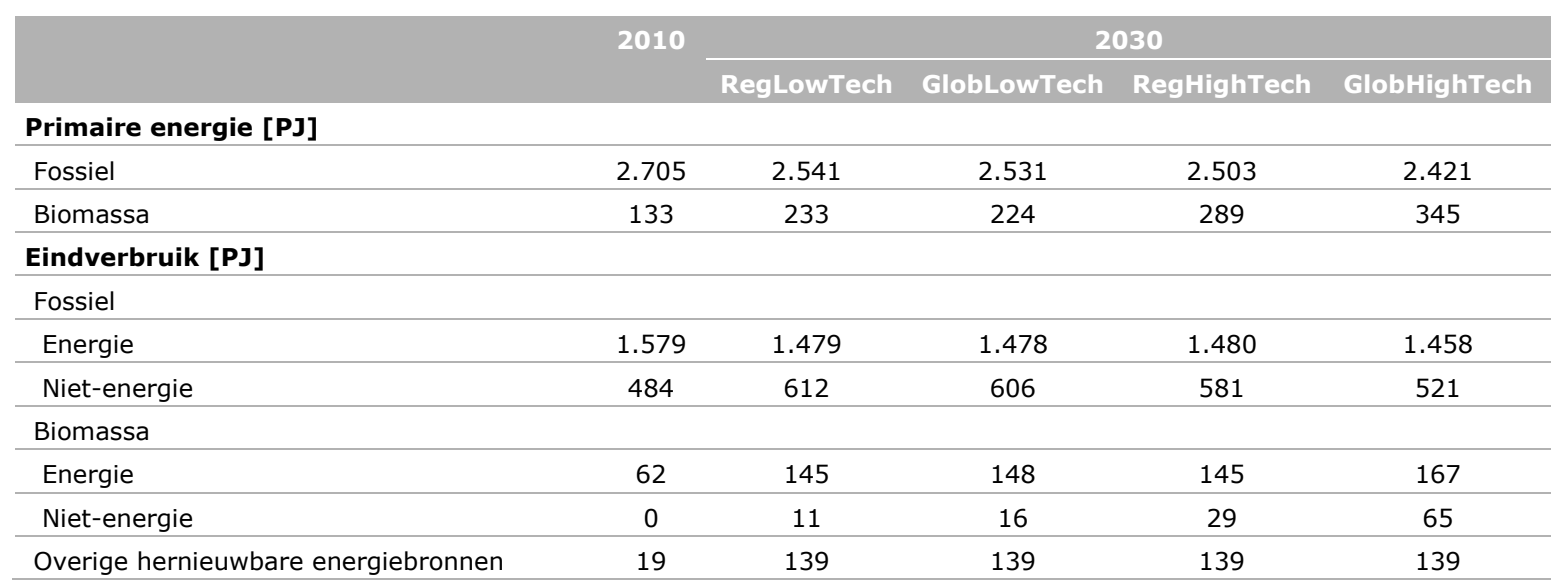

Technologische ontwikkeling is een belangrijke sturende kracht achter het verbruik van biomassa. In de HighTech-scenario's verschuift de productie van biobrandstoffen van eerste-generatie naar biobrandstoffen van de tweede generatie. In de LowTech-scenario's worden voornamelijk eerstegeneratie biobrandstoffen gebruikt. Geavanceerde thermochemische bioraffinaderijen zetten grote hoeveelheden lignocellulose om in FT-brandstoffen, waarbij de bijmengverplichting van $10 \%$ uit de Europese richtlijn voor hernieuwbare energie (RED = Renewable Energy Directive) in de HighTechscenario's overschreden wordt.

In de HighTech-scenario's worden aanzienlijke hoeveelheden lignocellulosehoudende biomassa gebruikt voor de productie van vergistbare suiker en/of ethanol, die voor een groot gedeelte worden gebruikt als feedstocks voor de chemische sector. In de HighTech-scenario's wordt de bijdrage van de chemische sector aan de totale productie van hernieuwbare energie (energie en niet-energie) steeds belangrijker. Biomassa blijft de grootste bron van hernieuwbare energie ( $55 \%$ van de totale eindhoeveelheid hernieuwbare energie) en bestrijkt meer dan $10 \%$ van de vraag naar chemicaliën in 2030.

\section{Macro-economisch effect}

Gegeven de aannames over macro-economische ontwikkeling en beleid heeft grootschalige toepassing van biomassa een positief effect op de toegevoegde waarde van de Nederlandse economie op de middellange termijn (tot 2030). Binnen alle scenario's laat alleen het RegLowTech scenario in 2030 nog een negatief effect zien op het BNP van $-€ 0,2$ mld. (figuur S.2). Open markten en investeringen in technologische ontwikkelingen leiden tot een positief effect op het BNP tot $€ 0,8$ mld. per jaar in 2030 (GlobHighTech-scenario). Vanaf 2030 voegen een hoge mate aan technologische ontwikkelingen en wereldwijde markten daarom jaarlijks $€ 1$ mld. toe aan het BNP (Figuur S.2). 


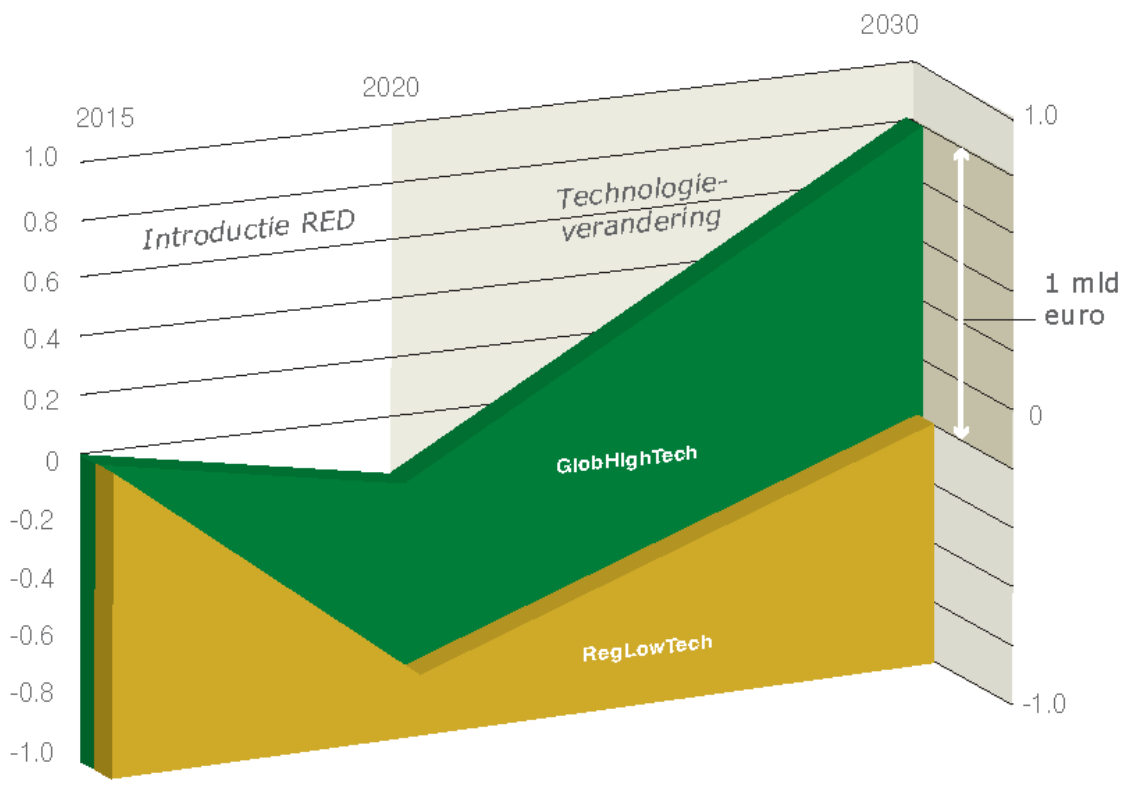

Figuur S.2 Effect op BNP van RegLowTech- en GlobHighTech-scenario's ten opzichte van het NoBioBased-scenario (absoluut verschil in $€$ miljarden).

In de 2015-2020 periode leidt het voldoen aan de doelstellingen voor hernieuwbare energie in alle scenario's tot een negatief effect op het BNP in 2020 vergeleken met een NoBioBased-scenario. Dit komt omdat bio-energietechnologieën niet kunnen concurreren met hun fossiele tegenhangers. Dit negatieve effect is sterker in de regionale scenario's ( $€$ 0,8 mld., zie 'RED + Regional': rode pijl) dan in de wereldwijde scenario's ( $€ € 0,2$ mld., zie 'RED + Global': blauwe pijl). De reden hiervan is dat de EU geen (relatief goedkope) biobrandstoffen uit Zuid- en Noord-Amerika kan importeren. Het positieve effect van technologische ontwikkelingen wordt zichtbaar in de 2020-2030 periode en is groter voor het scenario HighTech ( $€ 1 \mathrm{mld}$. jaarlijks, zie 'HighTech': blauwe pijl) dan voor het scenario LowTech ( $€$ 0,6 mld. jaarlijks, zie 'LowTech': rode pijl). Binnen de bio-economie vormt de landbouw een belangrijke sector in termen van toegevoegde waarde. Tussen 2015 en 2030 daalt de toegevoegde waarde van deze sector licht (met - $€ 160 \mathrm{mln}$.) in de NoBioBased-scenario's. In de vier MEV-IIscenario's stijgt de toegevoegde waarde van de landbouw in Nederland door de opkomst van een bredere bio-economie. De toegevoegde waarde in de biochemische sectoren stijgt met $€ 130 \mathrm{mln}$. in de LowTech-scenario's en met $€ 250$ mln. in de HighTech-scenario's (vergeleken met een NoBioBasedscenario in 2030). Het gebruik van bio-energie wordt in hoge mate gestuurd door beleidsmaatregelen en de toegevoegde waarde is redelijk constant in alle scenario's. Ten opzichte van het NoBioBasedscenario is de toegevoegde waarde van bio-energie circa $€ 280 \mathrm{mln}$. hoger in 2030 .

In het NoBiobased-scenario is de werkgelegenheid in de landbouw-, bio-energie- en biochemische sectoren in 2030 lager dan in 2015 vanwege de daling van de werkgelegenheid binnen de landbouw op de langere termijn. De groei van de bio-economie doet dit effect slechts gedeeltelijk teniet. De grootste effecten op de werkgelegenheid komen uit de productie van biobased chemicaliën in de HighTech-scenario's en in mindere mate in het GlobLowTech-scenario.

\section{Productiewaarde}

In 2030 verdubbelt de productiewaarde (dit is hetzelfde als omzet) van de nieuwe bioeconomiesectoren; van circa $€ 1,7 \mathrm{mld}$. in het LowTech-scenario naar bijna $€ 4$ mld. in het HighTechscenario. De productie van bio-energie blijft redelijk stabiel op $9 \%$ van de totale energieproductie, wat neerkomt op bijna $€ 600 \mathrm{mln}$. Groei vindt voornamelijk plaats in de productie van biobrandstoffen en nieuwe biobased chemicaliën, waarbij de productie stijgt van circa $€ 0,4 \mathrm{mld}$. en $€ 0,7 \mathrm{mld}$. in de 
LowTech-scenario's naar $€ 1,2 \mathrm{mld}$. en $€ 2 \mathrm{mld}$. in de HighTech-scenario's. De nieuwe biobased chemische productie voegt $1 \%$ toe aan de totale chemische productie in de LowTech-scenario's en $4 \%$ in de HighTech-scenario's, en beperkt daarmee gedeeltelijk de negatieve trend $(-10 \%)$ in de chemische productie.

\section{Vraag naar biomassa}

De nieuwe bio-economie heeft aanzienlijk meer biomassa nodig dan in 2015. Figuur S.3 geeft de vraag naar biomassa in 2030 weer. De vraag naar biomassa in 2030 varieert van 224 PJ tot 345 PJ. Dit laat zien hoe afhankelijk de bio-economie is van technologische ontwikkelingen en van de beschikbaarheid en prijs van biomassa. Bosbouwproducten, restproducten en hout van houtteelt met een korte omlooptijd leveren meer dan $50 \%$ van de totale verbruikte biomassa, dat gedeeltelijk als houtpellets wordt geïmporteerd uit landen buiten de EU28. Bio- en thermochemische bioraffinaderijen verbruiken maximaal $154 \mathrm{PJ}$ biomassa in ongeveer gelijke delen.
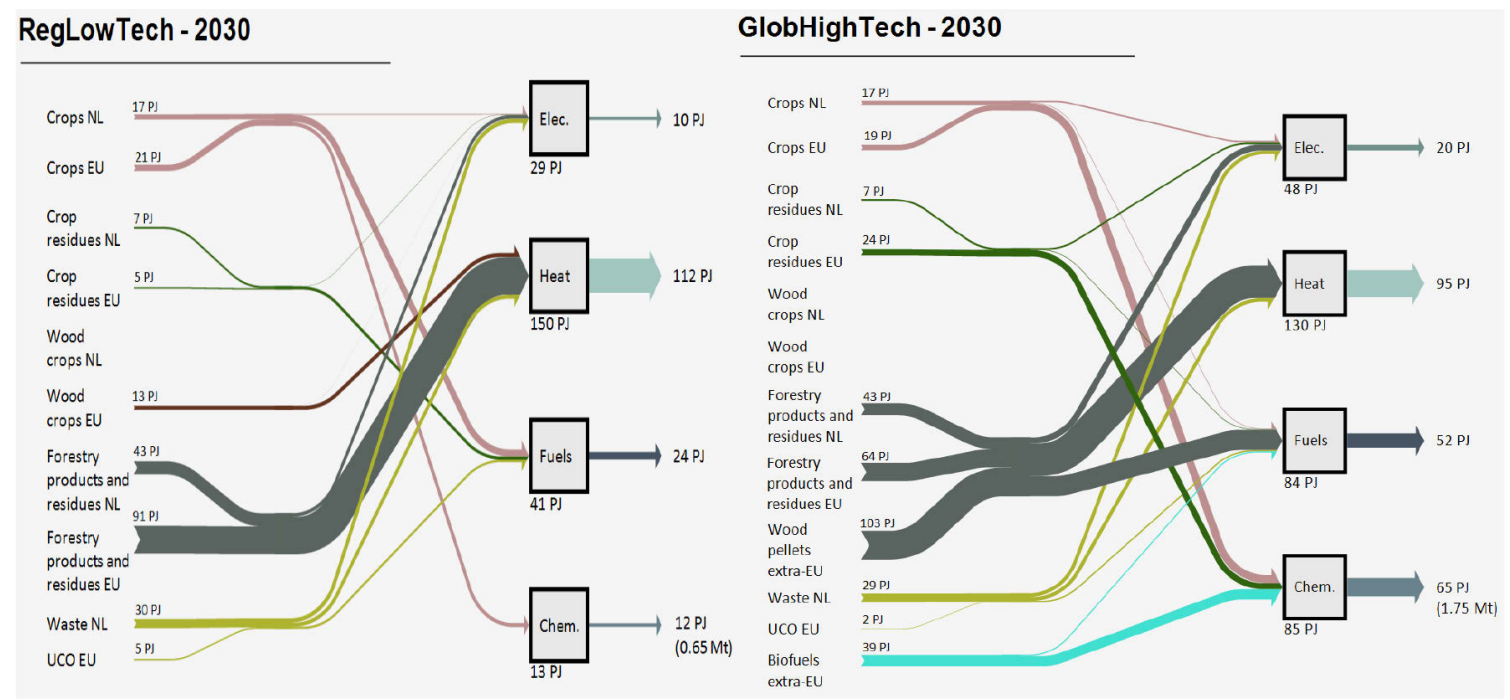

Figuur S.32 Biomassastromen voor de RegLowTech-en GlobHighTech-scenario's

\section{Handelsbalans}

De import van biomassa en de vervanging van fossiele brandstoffen hebben invloed op de handelsbalans. De handelsbalans van Nederland verslechtert op de korte termijn (tot 2020) ten opzichte van het NoBiobased-scenario. Dit negatieve effect wordt veroorzaakt door de introductie van de hernieuwbare energiedoelstellingen (RED), waarin fossiele technologieën vervangen moeten worden door duurdere biobased technologieën. De handelsbalans van fossiele energie en totale energie verbetert, maar dit effect wordt meer dan tenietgedaan door een hogere import van biomassa en met name een verslechtering van de handelsbalans van overige industrieën en diensten. Na 2020 worden biobased technologieën echter efficiënter en de Nederlandse export van tweede-generatie biobrandstoffen en vooral biobased chemicaliën zal stijgen. Dit remt de algemene daling van de handelsbalans. In de LowTech-scenario's wordt fossiele energie vervangen door eerste-generatie biobrandstoffen. Maar aangezien deze deels nationaal worden geproduceerd, zal de energiehandelsbalans hierdoor verbeteren. In de HighTech-scenario's neemt de productie van biobased en conventionele brandstof en chemicaliën toe. Dit leidt tot een hogere export van deze producten, waardoor de verlaging van de import en het gebruik van fossiele energie wordt beperkt. In andere landen zorgt de export van biobased producten echter voor vervanging van het gebruik van fossiele energie en een vermindering van de uitstoot van broeikasgassen.

\footnotetext{
2 Equivalent houtpellet $=17,1 \mathrm{PJ}$ per $\mathrm{mt}$ droge biomassa
} 


\section{Uitstoot van broeikasgassen}

Onder het bestaande energiebeleid en de gematigde $\mathrm{CO}_{2}$-belasting (zie Box 1 ), en ondanks de flinke toename van hernieuwbare energie uit wind en biomassa, blijft de uitstoot gelijk aan het niveau van 2010 , en is hiermee ver van het doel van een reductie van $40 \%$ in 2030 . Reductie wordt voornamelijk gerealiseerd door de sectoren elektriciteit en industrie. Door het gebruik van regionale en mondiale biomassa daalt de uitstoot met 1 tot $3 \%$ in de bottom-up analyses.

\section{Gevoeligheidsresultaten}

Bovenstaande resultaten zijn zeer gevoelig voor het klimaatbeleid en de prijzen van fossiele brandstof en feedstock. Via gevoeligheidsanalyses wordt geanalyseerd in hoeverre diverse aannames de systeem effecten en de macro-economische effecten door de opkomst van de bio-economie beïnvloeden.

\section{Hoge $\mathrm{CO}_{2}$-belasting}

Een hoge $\mathrm{CO}_{2}$-belasting ( $€ 71 / \mathrm{tCO}_{2}$ ) kan leiden tot een flinke daling van de uitstoot (circa $35 \%$ ten opzichte van 1990). Dergelijke belastingniveaus verhogen het verbruik van biomassa in het energiesysteem met een factor twee vergeleken met de referentiescenario's. Ze stimuleren de toepassing van windenergie tot boven het doelniveau van het Energieakkoord voor duurzame groei en leiden tot de ontwikkeling van $\mathrm{CO}_{2}$-mitigatietechnologieën zoals Carbon Capture \& Storage (CCS) en Bio-energie met CCS (BECCS). Daarnaast moet de efficiency van voertuigen worden verbeterd, wat mogelijk is met hybride voertuigen.

Een hoge reductie van de $\mathrm{CO}_{2}$-uitstoot in Nederland kent echter ook een prijs. Om de uitstoot binnen Nederland met $40 \%$ te verlagen, daalt het BNP met meer dan $€ 8 \mathrm{mld}$. (1\%) in het NoBioBasedscenario ten opzichte van het NoBioBased-hoofdscenario waarin de $\mathrm{CO}_{2}$-prijs $€ 26 / \mathrm{tCO}_{2}$ bedroeg. Indien de biomassamarkten wereldwijd van aard zijn en de technologische verandering in biobased technologieën hoger is (waarvan wordt uitgegaan in het GlobHighTech-scenario), dan kan deze daling van het BNP worden beperkt tot $€ 5 \mathrm{mld}$. (0,6\% van het BNP). Een grotere technologische vooruitgang en verdere opening van wereldwijde biomassamarkten vormen daarom een voorwaarde om de uitstoot met $40 \%$ te verlagen ten opzichte van 1990 .

\section{Prijzen van fossiele brandstoffen}

De grootschalige toepassing van biomassa wordt grotendeels aangestuurd door de prijs van fossiele brandstoffen. Als de prijs van fossiele brandstoffen met $50 \%$ stijgt, dan komt het verbruik van biomassa uit op tweederde van het beschikbare potentieel (770 PJ van circa $1 \mathrm{EJ}$ ) met een groter aanbod in sectoren als biobrandstoffen, biobased chemicaliën en elektriciteit uit wind.

Door lagere prijzen van fossiele energie ( $€ 45$ per vat olie) stijgen het Nederlandse BNP en de uitstoot van broeikasgassen. Onder deze omstandigheden is de bio-economie volledig afhankelijk van beleidsmaatregelen, omdat biobased technologieën niet kostenconcurrerend zijn en biomassa alleen wordt gebruikt om aan de bindende nationale RED-doelstelling (14\% in 2020) te voldoen. De productie van biobased chemicaliën zal nagenoeg verdwijnen. Een hoge technologische verandering resulteert in het vervangen van eerste-generatie biobrandstoffen door tweede-generatie biobrandstoffen, maar leidt niet tot productie boven de bijmengverplichting. De introductie van een bio-economie in een context van lage fossiele brandstofprijzen is kostbaar en leidt tot een verlies van $€ 2$ mld. aan BNP in het RegLowTech-scenario ten opzichte van het NoBiobased-scenario. Open markten en een grote veranderingen binnen de biobased technologieën verminderen dit negatieve effect op het BNP tot $-€ 400 \mathrm{mln}$.

\section{Overige biobased technologieën}

Binnen de referentiescenario's worden mestverwerking en een daaropvolgende omzetting in biogas niet als kostenefficiënt gezien. In een gevoeligheidsscenario met verplichte mestverwerking stijgt het verbruik van biomassa sterk tot 480-600 PJ. Dit komt met name door de grote hoeveelheden codigestaat (energiemaïs) die hiervoor benodigd zijn. In de vier referentiescenario's wordt het gebruik van vaste biomassa voor verwarming dan grotendeels vervangen door groen gas uit mestverwerking. Als aanvullend scenario werd ook de productie van biobased brandstof voor de luchtvaart beoordeeld. 
De resultaten geven aan dat biobased brandstof voor de luchtvaart pas in 2030 kostenconcurrerend is en dan alleen in de GlobHighTech-scenario's.

\section{Prijzen van feedstock}

De hoofdscenario's gaan niet uit van een aanvullende technologische verandering in de primaire sectoren. Een hogere opbrengst in de primaire sectoren, zoals land- en bosbouw, hebben een sterke positieve invloed op het BNP. Dit komt omdat vooral de exportgerichte agri-foodindustrieën hun marktaandeel kunnen verhogen zonder hun prijzen al te zeer te hoeven verlagen. Een $10 \%$ hogere opbrengst heeft een aanzienlijke invloed op het BNP (0,3\% van het BNP). De indirecte voordelen voor de nieuwe sectoren binnen de bio-economie zijn beperkt, omdat zij slechts een klein deel van de binnenlandse primaire landbouwproducten afnemen. Door een hogere opbrengst in de suikerbieten sector en lagere suikerprijzen stijgt de toegevoegde waarde met $€ 34 \mathrm{mln}$. in de bio-economie en met name in de suikersector. De lagere suikerprijs zorgt ook voor een hogere toegevoegde waarde van biobased chemicaliën ( $€$ 5-8 mln., vooral uit PLA-productie) en in mindere mate van biobrandstoffen.

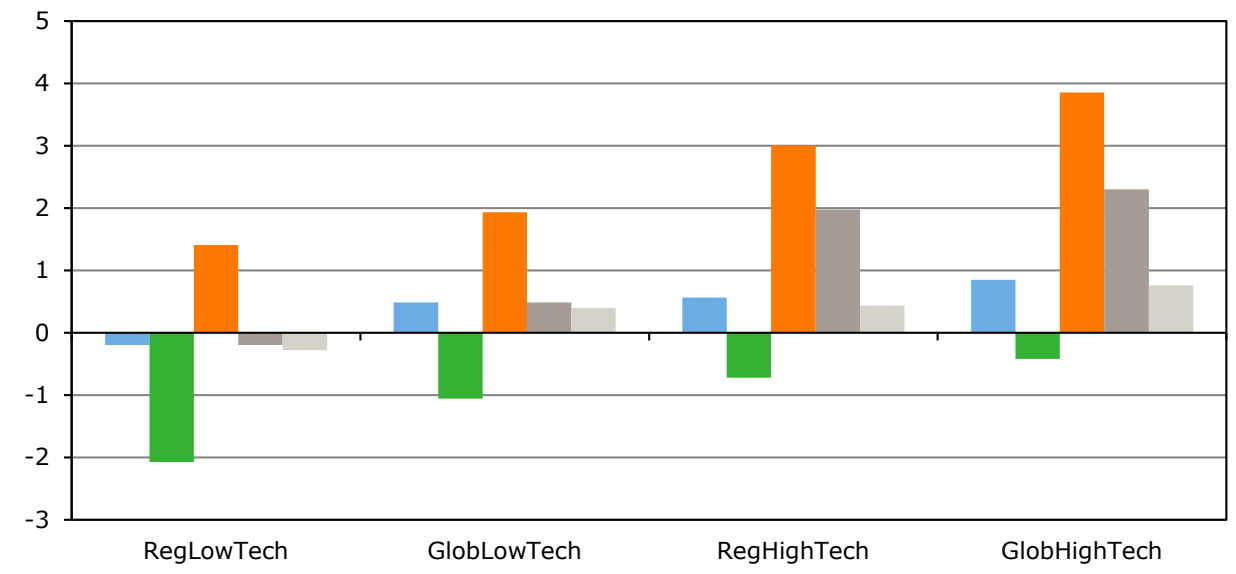

main $\quad$ low fossil price $\quad$ emission reduction whigh yields agriculture wigh sugar yields

Figuur S.4 GDP effecten van hoofd en gevoeligheid scenario's ten opzichte van NoBioBasedscenario's in 2030 (bln. euro).

Figuur S.4 geeft een overzicht van de gevoeligheidsanalyses en toont dat het macro-economische effect sterk negatief afhankelijk is van lagere fossiele energieprijzen en positief van stringent energie beleid en technologische ontwikkeling in de landbouwsectoren.

\section{Vergelijking met MEV-I}

Het economische effect van de bio-economie in de vier scenario's die werden bestudeerd in het MEVII-onderzoek, is kleiner dan de effecten in het MEV-I-onderzoek. De belangrijkste redenen hiervoor zijn:

i. De technologische vooruitgang binnen en buiten Nederland heeft zich de afgelopen 5 jaar volgens een 'LowTech'-scenario ontwikkeld. Dit houdt in dat de ontwikkeling van biobased technologieën in het MEV-II-onderzoek is vertraagd ten opzichte van aannames die voor 2015 in het MEV-Ionderzoek zijn gemaakt.

ii. De ambities voor de toepassing van biomassa zijn realistischer in MEV-II vergeleken met MEV-I. In de MEV-I studie werd aangenomen dat tot $30 \%$ van de primaire energievoorziening in Nederland uit biomassa afkomstig zou zijn in 2030.

iii. Het huidige onderzoek kijkt uitgebreider naar de concurrentie van andere hernieuwbare energiebronnen (voornamelijk wind en zon-PV) en omvat, in tegenstelling tot MEV-I, ook de optie 
van CO2-opvang en -opslag (Carbon Capture \& Storage/CCS). Dit leidt tot meer gebalanceerde toepassingstrajecten voor hernieuwbare energie in vergelijking met de vooraf gedefinieerde toepassingsscenario's voor biomassatechnologie van MEV-I.

Hoewel energie en materialen in MEV-I en MEV-II in verschillende mate worden toegepast, laten beide onderzoeken zien dat het gebruik van biomassa voor energie en chemicaliën positieve synergetische effecten kan hebben op de reductie van de $\mathrm{CO}_{2}$-uitstoot en op de energiezekerheid, en economische activiteiten binnen de landbouw-, chemie- en energiesectoren in Nederland kan genereren. De voorwaarden voor deze synergetische effecten zijn in beide onderzoeken hetzelfde, te weten:

i. De noodzaak tot een sterke technologieontwikkeling en beschikbaarheid van internationale, duurzame en aantrekkelijk geprijsde biomassabronnen.

ii. Een verschuiving van een food-based productie naar non-food lignocellulose feedstocks.

iii. Een snellere ontwikkeling van efficiënte productiesystemen, met name multi-output bioraffinaderijen die energie (voor elektriciteit, verwarming en vervoer) en chemicaliën produceren via zowel thermo- als biochemische omzettingsroutes.

\section{Conclusies}

Om te kunnen voldoen aan de kortetermijndoelen voor hernieuwbare energie en de $\mathrm{CO}_{2}$ reductiedoelen van het Nederlandse energie- en niet-energiesysteem suggereren de resultaten van dit onderzoek het volgende:

- De bio-economie kan een positieve bijdrage leveren aan de Nederlandse economie en het behalen van de $\mathrm{CO}_{2}$-reductiedoelen en kan daarbij de kosten van het realiseren van deze $\mathrm{CO}_{2}$-reductiedoelen beperken.

- De positieve macro-economische effecten van de bio-economie hangen af van (i) een snelle technologische verandering, (ii) hoge prijzen van fossiele energie, (iii) een wereldwijd handelssysteem en (iv) lage prijzen van biomassa. Een bio-economie die wordt aangedreven door een snelle technologische verandering en hoge beschikbaarheid van goedkope biomassa zorgt voor lagere macro-economische kosten van opties voor emissiereductie en maakt biobased opties minder prijzig in tijden van goedkopere fossiele energie.

- Om deze positieve macro-economische effecten en effecten op de $\mathrm{CO}_{2}$-uitstoot te realiseren is op korte termijn een stimuleringsbeleid noodzakelijk:

- Elektriciteitswinning uit wind en bodem- en buitenluchtwarmte (ondersteund door Nederlands beleid) kan een aanzienlijke bijdrage leveren aan de doelen op het gebied van hernieuwbare energie.

- Er zijn veel technologische ontwikkelingen binnen de biobased sectoren nodig om bio-energie en biochemicaliën kostenconcurrerend te maken. Bioraffinaderijen spelen hierbij wellicht een sleutelrol, omdat zij synergie tussen de diverse sectoren creëren.

- Een hoge $\mathrm{CO}_{2}$-belasting heeft een sterke invloed als beleidsinstrument.

- CCS en bio-CCS vormen belangrijke opties voor emissiereductie waarmee in het geval van een zeer ambitieus klimaatveranderingsbeleid (bijvoorbeeld het Verdrag van Parijs) aan $\mathrm{CO}_{2}{ }^{-}$ reductiedoelen voldaan kan worden, aangezien er geen andere kosteneffectieve alternatieven in het korte tijdsbestek van het onderzoek voorhanden zijn.

- Lage feedstockprijzen en toegang tot internationale biomassabronnen zijn noodzakelijk. Daarom moeten er stabiele internationale biomassamarkten worden ontwikkeld.

- Investeringen in technologische veranderingen in de landbouwsectoren (bijvoorbeeld suikeropbrengst) kunnen bijdragen aan een groeiende bio-economie en een positieve handelsbalans.

\section{Toekomstig onderzoek}

De MEV-II studie is ontworpen voor de middellange termijn tot2030 en op basis van het toepassingspotentieel van grootschalige biomassatechnologieën binnen de diverse sectoren. Vooruitzichten op de langere duur (bijvoorbeeld 2040, 2050) zullen hoogstwaarschijnlijk afwijken van hetgeen voor 2030 is gepresenteerd. Daarom bevelen wij aan dat er bij toekomstig onderzoek analyses voor een langere termijn worden uitgevoerd (bijvoorbeeld 2040, 2050), waarin verdere technologische ontwikkeling en schaalvoordelen kunnen leiden tot een grotere rol van biomassa. Er zullen namelijk vervangende materialen en nieuwe en meer geavanceerde alternatieve bronnen van hernieuwbare energie beschikbaar komen. Dit is met name relevant voor technieken waarmee biomassa tot chemicaliën wordt omgezet en waarbij geavanceerde routes een belangrijke invloed 
kunnen hebben (bijvoorbeeld de valorisatie van lignine tot hoogwaardige producten). Ten slotte zou een onderzoek over een langere periode zich niet alleen moeten richten op bulkvervanging van fossiele brandstoffen, maar ook op producten met een hoge waarde/laag volume (bijvoorbeeld fijnchemicaliën). Dergelijke routes spelen door het kleine marktvolume wellicht geen belangrijke rol bij substantiële emissiereductie of bij het vervangen van grote hoeveelheden fossiele brandstoffen, maar ze kunnen toch van grote invloed zijn op de bio-economie wat betreft toegevoegde waarde en werkgelegenheid. Dit heeft onvermijdelijk tot gevolg dat ook de onzekerheden in verband met langere termijnprognoses toenemen, wat in scenario- en gevoeligheidsanalyses vastgelegd kan worden. De resultaten bieden echter inzicht in welke technieken momenteel ondersteuning verdienen om zo hun toepassing in de toekomst te kunnen bevorderen. De belangrijkste factoren zijn schaalvoordelen, synergieën tussen technologieën, bijvoorbeeld de valorisatie van nevenstromen, die van essentieel belang zijn voor de omzet binnen de Nederlandse economie. Ten slotte adviseren wij om deze studie iedere drie jaar te herhalen gegeven de snelle technologische ontwikkelingen en de veranderingen in beleid. 


\section{Units and abbreviations}

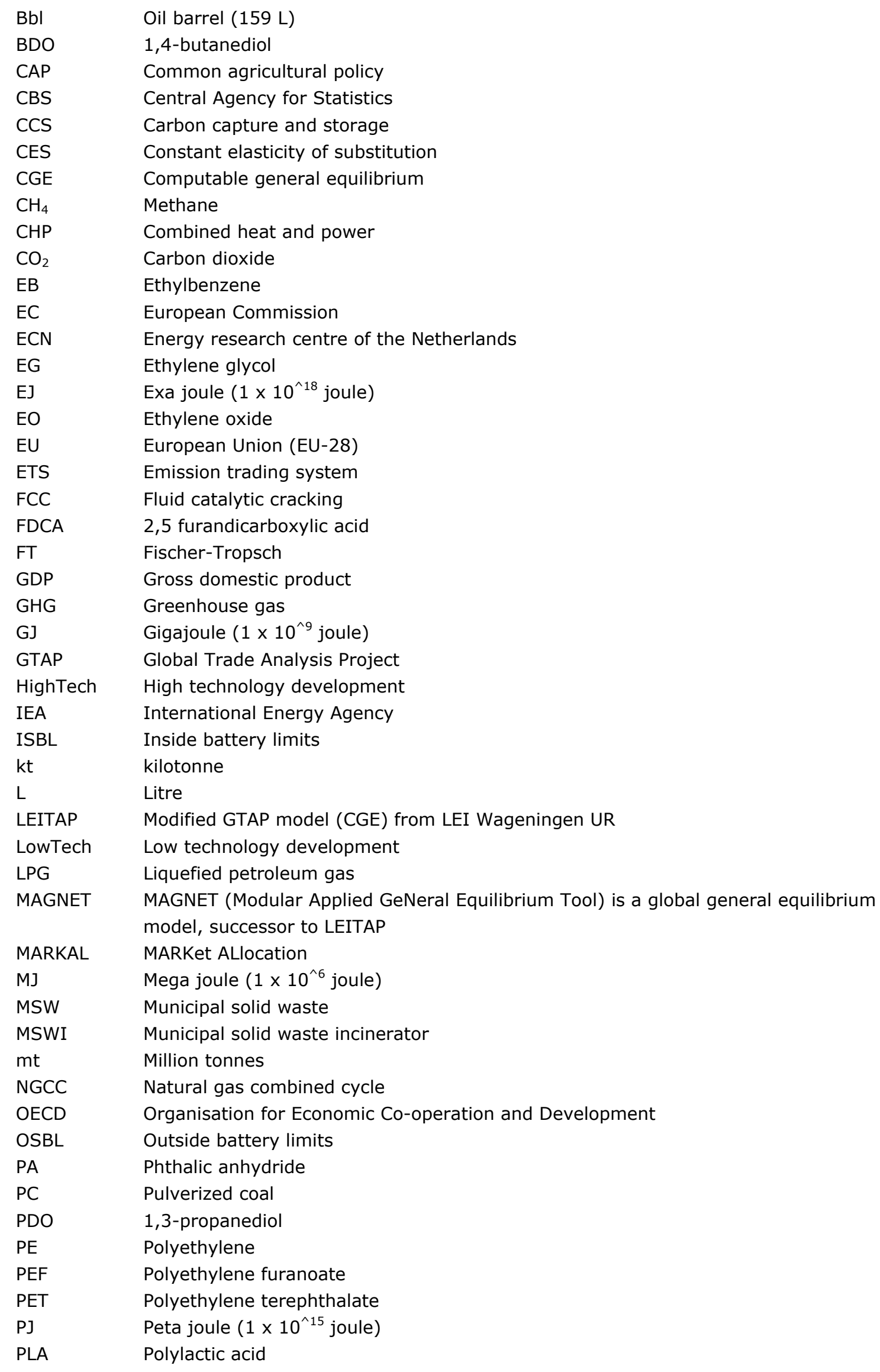


$\mathrm{PO}$

$\mathrm{PP}$

ppm

PTA

PTT

RED

RES

SA

SRC

SRES

$\mathrm{TJ}$

$\mathrm{yr}$
Propylene oxide

Polypropylene

parts per million

Terephthalic acid

Polytrimethylene terephthalate

Renewable energy directive

Renewable energy sources

Succinic acid

Short rotation coppice

Special Report Emissions Scenarios

Tera joule $\left(1 \times 10^{\wedge 12}\right.$ joule $)$

Year 


\section{Introduction to MEV II}

\section{$1.1 \quad$ Background}

The Netherlands Ministry of Economic Affairs (Min EZ RVO) and the Dutch top-sector platform for knowledge development and innovation of the cross-cutting theme 'bio-based economy (TKI-BBE)' commissioned a study titled 'Macroeconomic outlook of sustainable energy and biorenewables innovations' (abbreviated as MEV II). The main objective was to provide insights into the macroeconomic impacts of the large-scale deployment of biomass use in the Netherlands up to 2030.

MEV II built on the first macroeconomic impact assessment study (MEV I; Appendix 1), which was carried out in 2009 (Hoefnagels et al., 2009, 2014). In MEV I, an Excel-based bottom-up energy model and a top-down macroeconomic model were integrated to analyse the macroeconomic and environmental impacts of specific biomass conversion routes to energy and chemicals (in terms of $\mathrm{CO}_{2}$ emissions, value added and job creation). Although it was innovative, MEV I had several methodological shortcomings, resulting in a number of key recommendations to be tackled in a followup study:

- In the macroeconomic model, biomass and bioenergy conversion technologies were modelled at a high aggregation level. The disaggregation of energy and chemical industries is both desirable and a more reliable representation of advanced conversion routes that are currently being considered by industry and research entities (biorefineries, new platform chemicals, etc.). In recent years, more research data on these technologies have become available.

- In MEV I, GDP was exogenous and the size of the bio-based sectors was determined by exogenously given bio-based shares in transport fuels, electricity and chemicals. GDP and the bioeconomy were to become endogenous within the macroeconomic model. Furthermore, results were given only at the national level. MEV II was expected to give some first indications at the regional level.

- Residues and biomass potentials were not included in the macroeconomic model and should be treated separately.

- In the macroeconomic model, fossil-based conversion technologies were modelled at a high aggregation level and renewable energy sources (e.g. wind, sun) were not included.

- The origin of international biomass sourcing was not specified and its sustainability impact was not addressed. The Dutch business community wants to import biomass from countries that produce it in a sustainable manner.

The aim of MEV II was to overcome the aforementioned shortcomings of MEV I, by providing insights into:

- The macroeconomic effects on energy use and $\mathrm{CO}_{2}$ emissions of different applications of biomass (e.g. energy, biofuels, chemicals) in the Netherlands in 2030. GDP and bio-based shares in the various uses were to become endogenous. Some regional results were to be included (Module I).

- The deployment of key energy, transport and chemical technologies, including changes in the consumption of fossil fuels and renewable energy technologies (e.g. wind, solar), that compete with the bio-based applications in the Netherlands (Module II).

- The international origin and sourcing of biomass and the related sustainability performance (Module IV).

In this new study, the MARKAL-NL-UU model (for energy and chemical industry sectors) was used instead of the Excel-based bottom-up model applied in MEV I. Also, an advanced version of the Modular Applied GeNeral Equilibrium Tool (MAGNET) was used as a top-down model, with many more disaggregated bio-based transport, electricity and chemical sectors and more disaggregated fossilbased and renewable sectors.

In MEV II, analyses were again carried out by using scenarios that capture key uncertainties and issues regarding the macroeconomic impacts of the bioeconomy in the Netherlands. The scenarios 
focused on the openness of biomass markets (sourced from the EU market versus the global market) and the rate of technological development (high/low degree of development). Biomass prices and availability are affected by trade openness and conversion costs by rate of technical change. Uncertainty and sensitivity analyses were conducted to investigate, for example, the impact of varying $\mathrm{CO}_{2}$ and energy prices.

\subsection{Objectives}

The aim of the MEV II study was to provide insights into the main uncertainties regarding the deployment of resources, energy and chemicals production, avoided emissions, production costs, investment levels over time and the macroeconomic impacts of various technology applications. To do so, scenario analyses, using a bottom-up energy system model (MARKAL-NL-UU) and a top-down macroeconomic model (MAGNET), were performed. The MEV II study had to answer the following main question for the Netherlands, up to 2030:

- What are the macroeconomic impacts and effects on energy use and $\mathrm{CO}_{2}$ emission of different applications of biomass (e.g. bioelectricity, bio-based heat, biofuels, bio-based chemicals)?

In order to address this main research question, the following questions needed to be answered:

- What are insights in the development of key energy/chemical technologies including changes in supply of fossil fuels, CCS and renewable energy technologies (e.g. wind, solar) that compete with the bio-based applications? What are the insights into the international origin and sourcing of biomass and the related sustainability performance?

- What are the economic opportunities/consequences of the various applications of raw materials from biomass? What is the current and potential contribution of the bioeconomy to the GDP (euros), employment (number of jobs) and trade balance ( $€$ millions) at both the national and the regional level?

- What is the current and potential contribution of the Dutch bioeconomy to the national energy use $(P J)$ and $\mathrm{CO} 2$ emissions?

- What affects the profitability of biomass and bio-based energy and chemical products (compared to fossil-based processed energy and chemical products) and what are the biggest uncertainties in this regard?

\subsection{Scope}

\subsubsection{Sectors, regions and period}

The European Commission (EC) formulated the following definition of 'the bioeconomy' in 'Communication on Innovating for Sustainable Growth: A Bioeconomy for Europe' (EC, 2012):

'The bioeconomy encompasses the production of renewable biological resources and their conversion into food, feed, bio-based products and bioenergy. It includes agriculture, forestry, fisheries, food and pulp and paper production, as well as parts of chemical, biotechnological and energy industries. Its sectors have a strong innovation potential due to their use of a wide range of sciences (life sciences, agronomy, ecology, food science and social sciences), enabling and industrial technologies (biotechnology, nanotechnology, information and communication technologies (ICT), and engineering), and local and tacit knowledge.'

The sector approach adopted by the MEV II study will support policymakers and entrepreneurs in monitoring the changes occurring in the economy as they are today and will be tomorrow, with the technologies as they are today and will be tomorrow. Table 2 depicts the bioeconomy sectors that fit the EC definition of the bioeconomy. 


\section{Table 2}

\section{Bioeconomy sectors}

\begin{tabular}{llll} 
No & Sector & No & Sector \\
1 & Agriculture, forestry and fisheries & 6 & Pulp and paper \\
\hline 2 & Food and feed & 7 & Chemical industry (bio-based) \\
\hline 3 & Construction, building material (bio-based) & 8 & Energy, incl. transport (bio-based) \\
\hline 4 & Textile and clothing (bio-based) & 9 & R\&D services in biomass \\
\hline 5 & Wood industry (bio-based) & & \\
\hline
\end{tabular}

The bioeconomy sectors listed in Table 2 can be divided into:

- Traditional bio-based sectors: agriculture, forestry and fisheries, food and feed, wood, pulp and paper, textile and clothing (bio-based part).

- New bio-based sectors: bio-based parts of construction, chemical industry and energy sectors (including transport).

The focus of the MEV II study was on analysing the potential development of the new bio-based markets in the Netherlands in particular (energy, transport and chemical industry) up to 2030. First, we assessed the importance of the broader range of subsectors that compile the entire bioeconomy in the Netherlands. This was done based on statistics and on analyses with the disaggregated agricultural Input-Output table of the Dutch economy. Thus, the traditional bio-based sectors, such as agriculture and food and feed, were also taken into account.

Second, scenarios were used to deal with the uncertainties regarding the availability of biomass and the speed of technology rate. Both factors are expected to effect the potential development of the bioeconomy in the Netherlands from the reference year until 2030. Given the scenarios assumptions, the projected bioeconomy capacity at the national level is downscaled to get insight into the macroeconomic effects at the regional level in the Netherlands.

Table 3 summarizes the boundaries of MEV II. Table 4 presents the indicators for which the study provides an outcome.

\section{Table 3}

\section{Scope of MEV II}

\begin{tabular}{|c|c|c|}
\hline Scope & Focus & Remarks \\
\hline Sectors & $\begin{array}{l}\text { Energy (electricity, heat) } \\
\text { Transport } \\
\text { Chemical } \\
\text { Primary (agriculture, forestry) }\end{array}$ & $\begin{array}{l}\text { Looking at competition across bio-based, fossil-based } \\
\text { and renewable technologies (heat is covered in } \\
\text { MARKAL-NL-UU, but not in MAGNET) }\end{array}$ \\
\hline Geographical & $\begin{array}{l}\text { Netherlands } \\
12 \text { Provinces }\end{array}$ & $\begin{array}{l}\text { MAGNET has also results for a few other EU countries } \\
\text { and a rest of World aggregated region. }\end{array}$ \\
\hline Years & $\begin{array}{l}2010 \text { (reference year for MARKAL); } 2015 \\
\text { (reference year for MAGNET) } \\
\text { 2030: end simulation year }\end{array}$ & \\
\hline Scenarios & $\begin{array}{l}\text { Openness of markets (biomass sources) } \\
\text { Rate of technological development }\end{array}$ & $\begin{array}{l}\text { Additional sensitivity analysis with regard to energy } \\
\text { prices, } \mathrm{CO}_{2} \text { targets }\end{array}$ \\
\hline
\end{tabular}


Table 4

Indicators of MEV II

\begin{tabular}{ll} 
Indicators & Metrics \\
Value added (GDP) & $€$ millions/sector; $€$ millions/tonne biomass; $€$ millions/tonne \\
\hline Production volume & $\mathrm{PJ} /$ sector, million tonnes/sector \\
\hline Turnover & $€$ millions/sector \\
\hline Energy use & $\mathrm{PJ} /$ sector \\
\hline GHG emission & $\mathrm{CO}_{2}$ equivalents/sector \\
\hline Trade balance & $€$ millions/sector \\
\hline Employment & $€$ millions; jobs/sector \\
\hline Biomass source & Type and geographic origin of biomass supply
\end{tabular}

\subsubsection{Policies}

The bioeconomy is often regarded as a vehicle for green growth, although it is clear that the transition from a fossil-based economy to a sustainable bioeconomy will be a complicated system transition with a long time horizon. This transition will be accompanied by trade-offs at the:

- Economic level: development of new cross-sectoral relations that must lead to new clusters and above all to new competitiveness business cases. Also the dependency on fossil energy sources and imports from unstable countries is a concern.

- Social level: job creation, ensuring food security and affordable food prices.

- Environmental level: managing of natural resources, biodiversity and climate change.

The EC launched the Bioeconomy Strategy (EC, 2012) to tackle these challenges. Dutch policymakers also show great interest in solving the aforementioned issues. They therefore launched - together with stakeholders from the private sector in a public private partnership (PPS) structure - the MEV II study. Both EU and national policies play a role in investigating the contribution of the potential biorenewable sectors in the Netherlands in 2030. In particular climate and energy policies are taken into account, like the EU RED (EC, 2009), the Dutch Energy Agreement (SER, 2013), and $\mathrm{CO}_{2}$ price in accordance with the New Policy scenario of the IEA World Energy Outlook (IEA, 2014) and set of sensitivity scenarios including more ambitious climate targets (e.g. high $\mathrm{CO}_{2}$ price, reduction target). and the EU targets for $\mathrm{CO}_{2}$ reduction in 2030 (EC, 2014).

\subsubsection{Contents of this report}

This report is structured as follows. Section 2 presents the state of the art of the biorenewable technologies and the macroeconomic performance of the sector-broad bioeconomy in the Netherlands in 2013. Section 3 describes the method applied in MEV II as well as the data, assumptions and scenarios used. Scenario results on the potential development patterns of the biorenewable sectors in Netherland are discussed in Section 4. The simulated results are for 2030 and are provided for each of the scenarios for both the bottom-up MARKAL-NL-UU and the top-down MAGNET model. Sensitivity analyses are given in Section 5 . This is followed by Section 6 , in which the main findings are presented and discussed and conclusions are presented in Section 7. 


\section{Status of the Dutch bioeconomy in 2013}

This section concerns the current status of the bioeconomy in the Netherlands. Section 2.1 describes the country's electricity, transport and chemical production and the contribution of biomass to the Dutch energy system. Section 2.2 describes the economic performance of the bioeconomy complex in terms of turnover, value added and employment.

\subsection{Biorenewable technologies}

In 2013, total final energy consumption for energy and non-energy purposes was around 2800 PJ. Approximately $75 \%$ was consumed for energy purposes; the remainder was consumed primarily by industry as feedstock (i.e. non-energy; see Section 2.1.3).

Table 5 presents the consumption of energy commodities by energy carrier per sector. Excluding the energy sector's own energy consumption, the remaining sectors consumed approximately equal shares of energy (i.e. one quarter each). Excluding electricity and heat generation, which are discussed in more detail in Section 2.1.1, fossil fuels contributed almost exclusively to the final energy demand of these sectors. Natural gas consumption by private households and services, agriculture and fisheries, primarily for heating purposes and by industry for process heat generation, accounts for half of final energy consumption (excluding energy and co-generated heat). Crude oil and petroleum products, which were mainly consumed by the transport sector as fuels, account for the remaining part (Section 2.1.2).

Table 5 shows that electricity production, heat supply (e.g. to district heating systems), direct heat generation by households, services, agriculture and fisheries, industry, and the production of transport fuels are key focus areas for the Dutch energy system. Sections 2.1.1-2.1.4 discuss these in more detail.

\section{Table 5}

Final energy use (PJ) for energy purposes by energy carrier and sector in the Netherlands in 2013 (CBS, 2015)

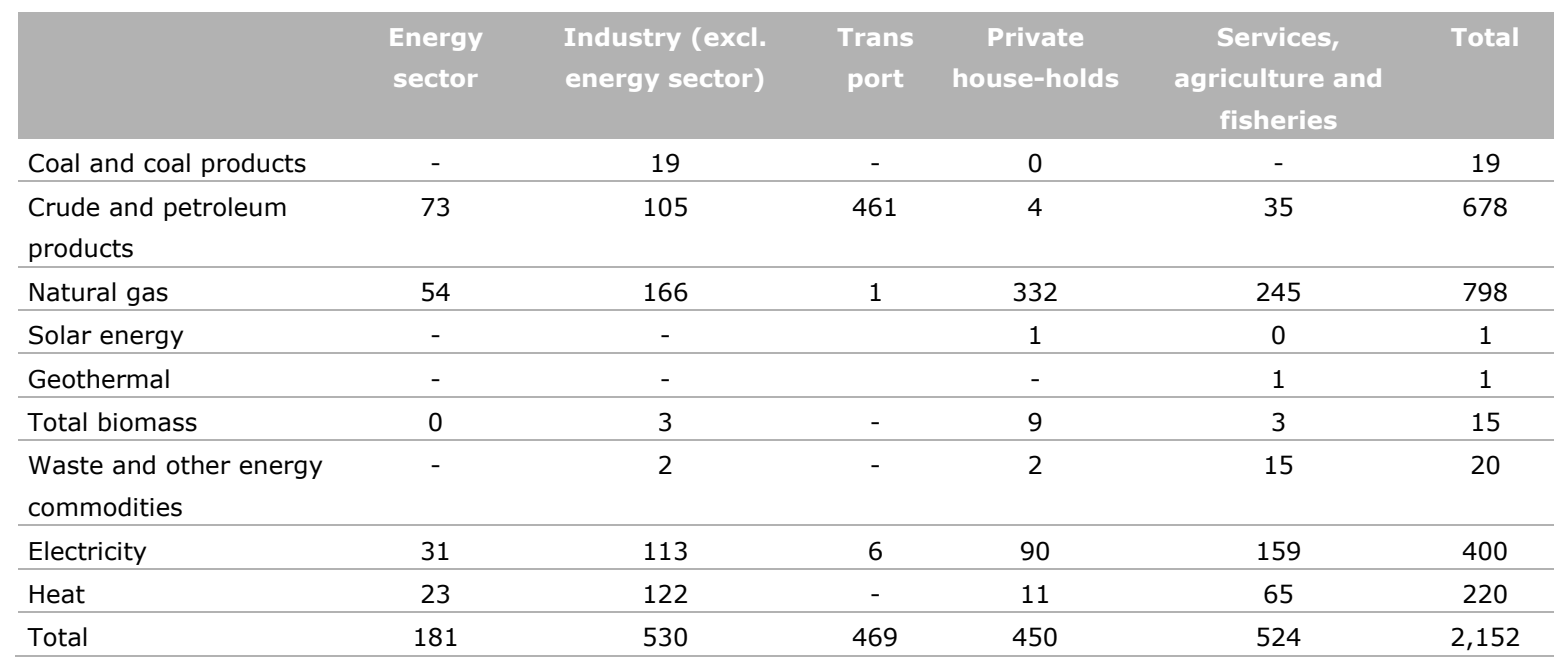

a In the latest CBS statistics, natural gas and electricity consumption by the services, agriculture and fisheries sector were not reported. In this table, the consumption by this sector is estimated by the total balance. 


\subsubsection{Electricity technology mix}

Figure 1 presents the electricity production by source in the Netherlands in 2013. Of the $430 \mathrm{PJ}$ consumed, $74 \%$ was from fossil fuels, ${ }^{3}$ primarily natural gas. The contribution of renewable resources was approximately $10 \%$, with biomass and wind contributing equal shares ( $20 \mathrm{PJ})$. The remainder (15\%) was net imports. ${ }^{4}$ In terms of resource use to supply electricity and (sold) heat, fossil resources amounted to $850 \mathrm{PJ}$ and approximately $80 \mathrm{PJ}$ of biomass were consumed.

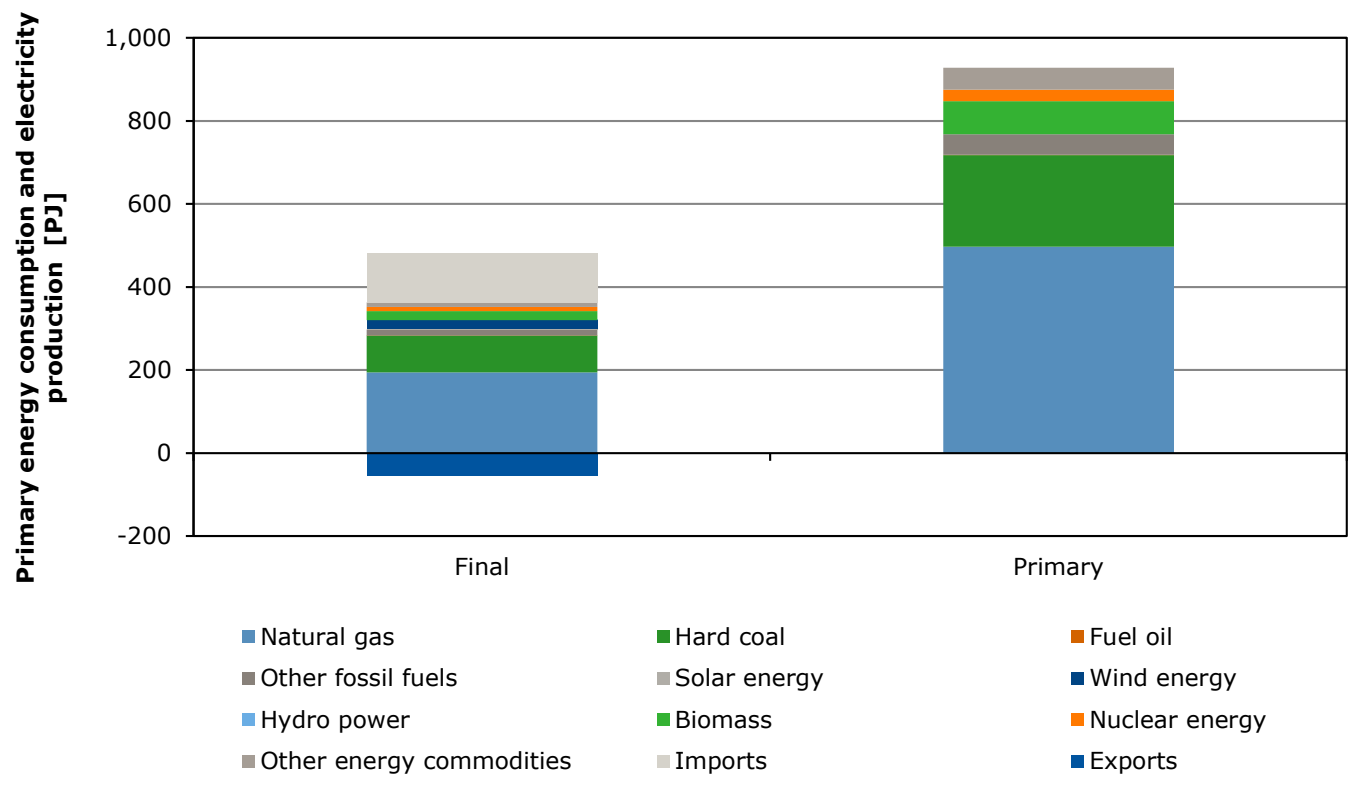

Figure 1 Primary energy consumption for electricity and heat (on the right) and electricity production by energy commodity (on the left) in the Netherlands in 2013 (CBS, 2015)

\subsubsection{Transport technology mix}

Figure 2 presents the energy use by transport sectors in the Netherlands in 2013. Road transport is by far the most important consumer of energy, as it accounts for $95 \%$ of transport fuels. Figure 3 presents a breakdown of the fuel types consumed in road transport. Diesel and petrol supplied $97 \%$ of the final demand. Biofuels supplied approximately $13 \mathrm{PJ}$ of the final energy demand in the transport sector; the biofuels are blended with diesel and petrol (see also Section 2.1.2). Note that in Figure 2, aviation fuels refer to domestic consumption and not production, which is analysed by the bottom-up model.

\footnotetext{
3 In this description, fossil fuels/resources include natural gas, hard coal, fuel oil, other fossil fuels, nuclear energy and other energy commodities. Renewable resources include solar, wind, hydro and biomass.

4 In 2013, total imports of electricity amounted to $120 \mathrm{PJ}$ and exports amounted to $54 \mathrm{PJ}$. The $15 \%$ share corresponds to net imports (i.e. imports minus exports), which was 66 PJ in 2013.
} 


\section{Energy use in the transport sector}

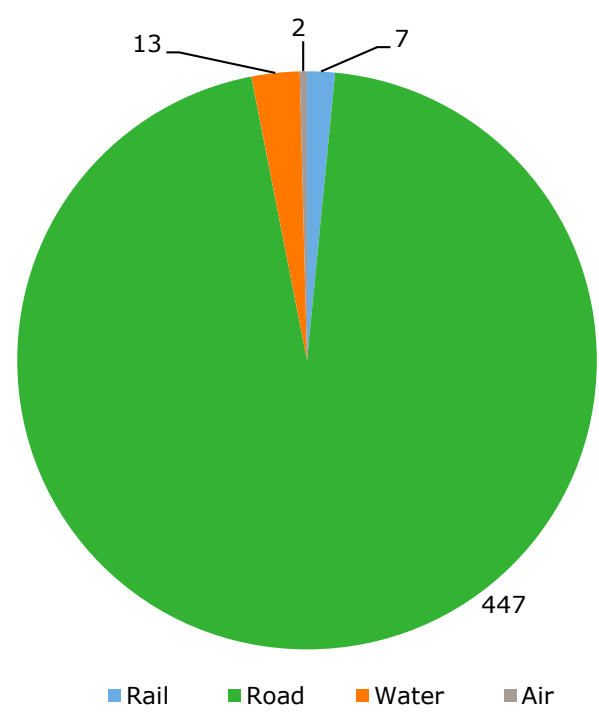

Figure 2 Energy use in PJ by the transport sectors in the Netherlands in 2013 (CBS, 2015)

\section{Energy use in road transport by fuel type}

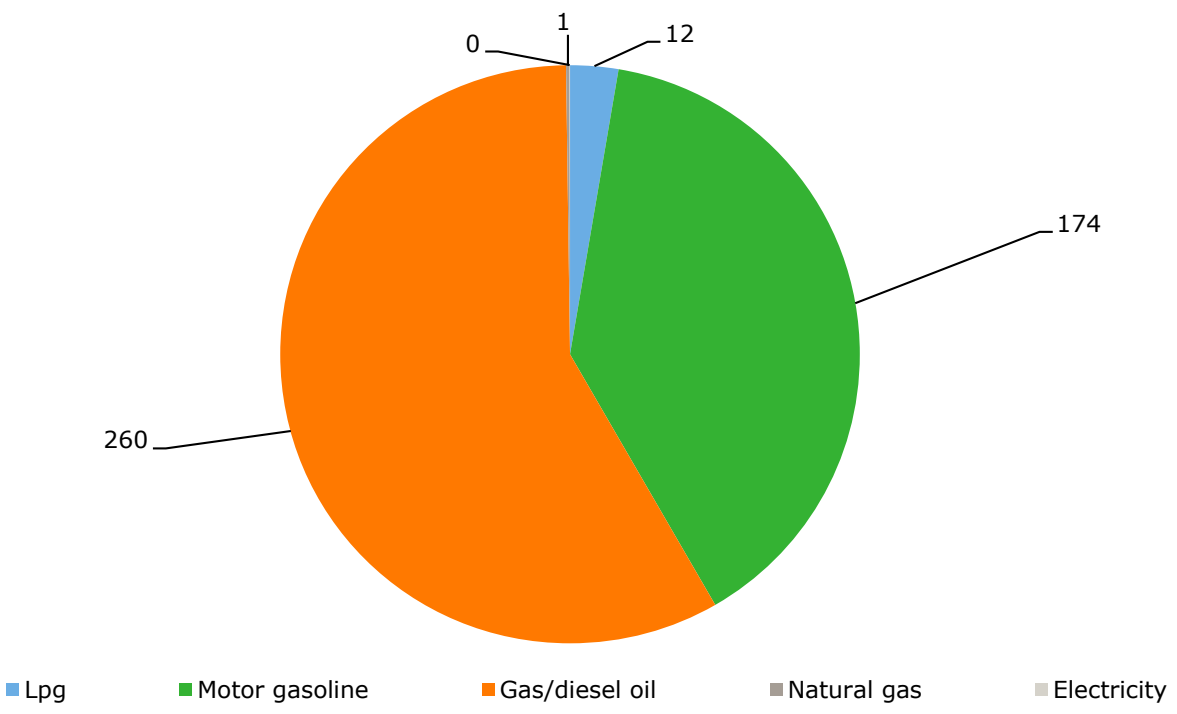

Figure 3 Energy use by fuel type in road transport in the Netherlands in 2013 (CBS, 2015)

\subsubsection{Chemicals technology mix}

Table 6 presents the use of energy for non-energy purposes by sector in the Netherlands in 2013. It shows that the organic basic chemical sector and the fertilizer industry consumed $82 \%$ of the total non-energy use. The main energy carriers are oil and oil products in the organic basic chemical sector ( $91.5 \%$ of the sector's total non-energy use) and natural gas in the fertilizer sector (100\% of the sector's total non-energy use). The consumption of oil products by the organic basic chemical sector and natural gas by the fertilizer sector represent $80 \%$ of total non-energy use in the Netherlands in 2013. These sectors were also the focus of the present study. 


\section{Table 6}

Non-energy use (PJ)in the Netherlands by sector and fuel in 2013 (CBS, 2015)

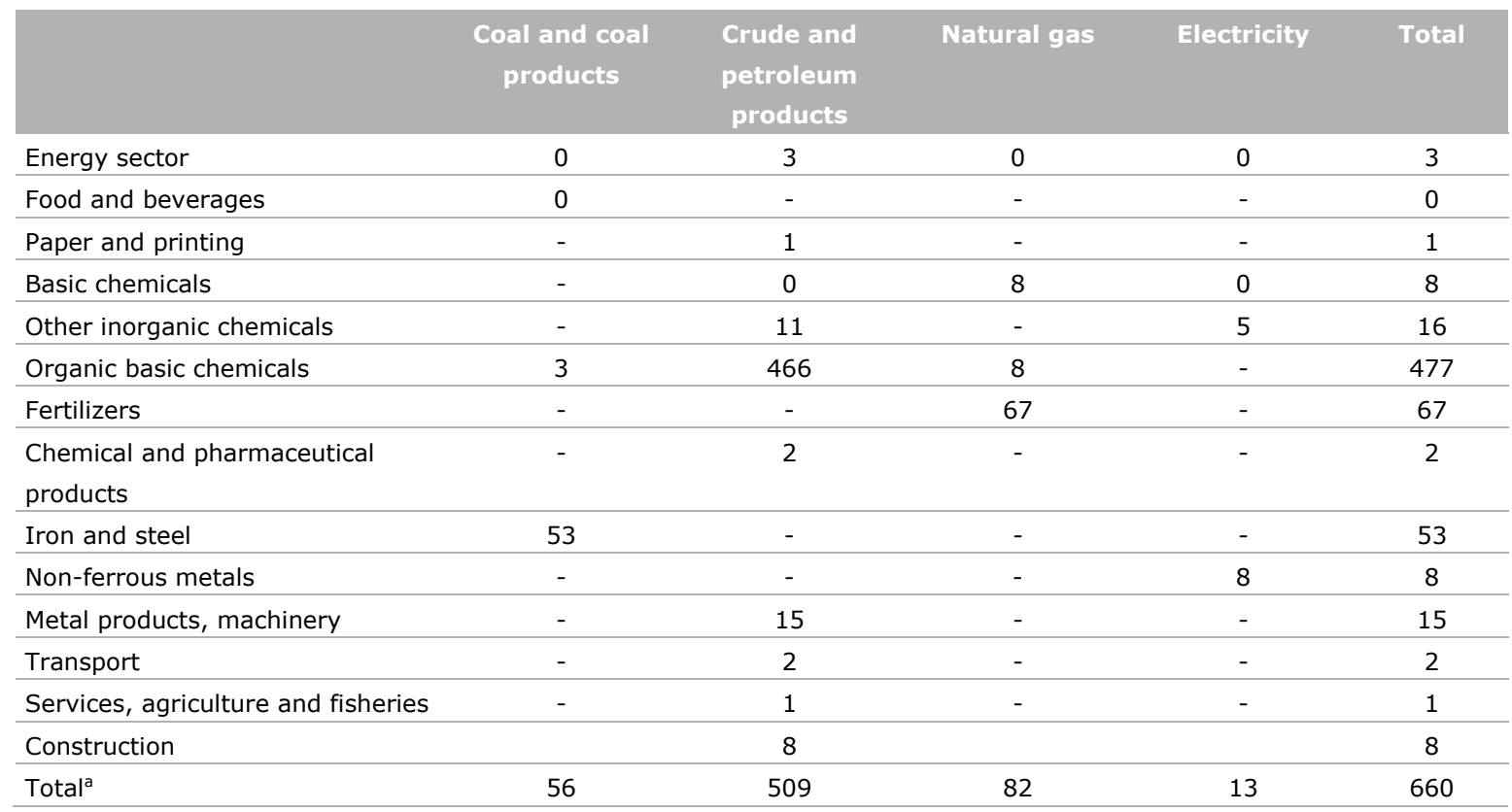

a Note that the detailed energy balances per fuel input indicate $8.79 \mathrm{PJ}$ of bitumen consumption. In this table we correct this figure by deducting $0.75 \mathrm{PJ}$ so that the overall non-energy use is balanced.

\subsubsection{Contribution of biomass in the Dutch energy system}

Figure 4 shows the consumption of biomass in the Netherlands over time (2005-2013). During that period, biomass consumption increased significantly from $42 \mathrm{PJ}_{\text {final }}$ in 2005 to almost $70 \mathrm{PJ}_{\text {final }}$ in 2013. Biofuels, biomass co-firing, organic fraction of municipal waste incineration and biomass combustion in wood stoves for heating were major applications. In 2011, $26 \mathrm{PJ}$ primary of biomass were used for cofiring. Approximately $20 \mathrm{PJ}_{\text {primary }}$ was woody biomass (94\% imported from Canada and the USA, 6\% from domestic sources). The remaining supply (6-7 $\mathrm{PJ}_{\text {primary }}$ ) was met by animal meal and agricultural residues (Lensink et al., 2014). In 2013, 50\% of gross final consumption of biomass was for heat, approximately $31 \%$ was for electricity and the remaining $18.7 \%$ was for transport fuels (Figure 5 ).

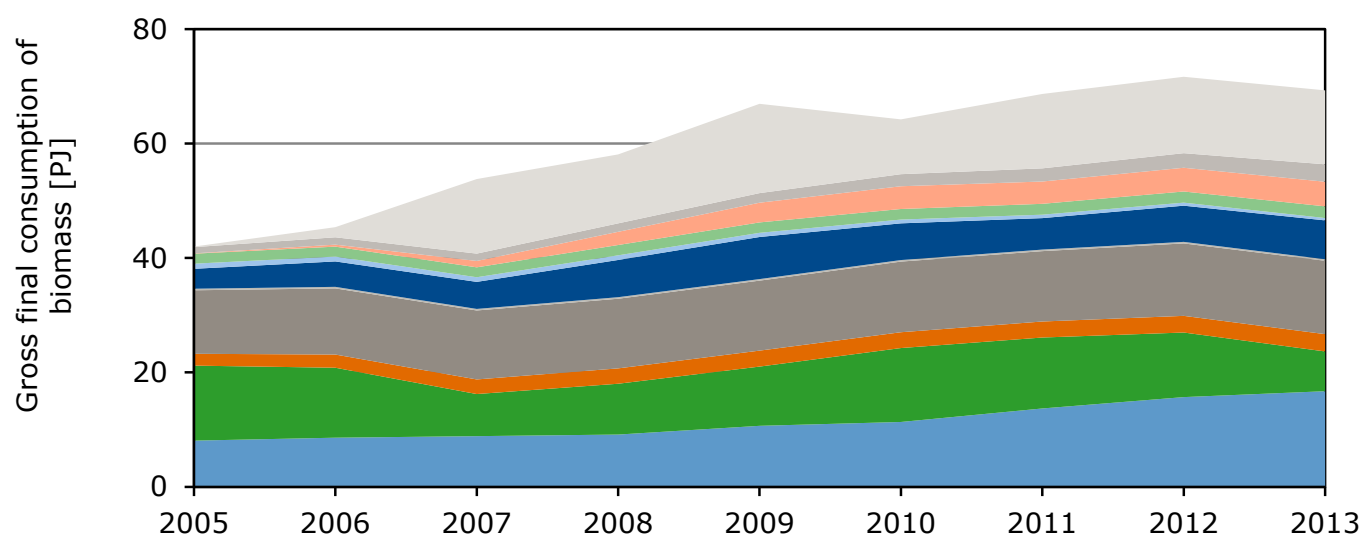

Biofuels for road transport

Biogas, co-digestion of manure

Biogas from landfills

Charcoal

- Wood boilers for heat in companies

- Municipal solid waste, renewable fraction
Biogas, other

Biogas from sewage water purification

- Other biomass combustion

Wood stoves in houses

n Co-firing of biomass in central electricity plants

Figure 4 Gross final consumption of biomass in the Netherlands between 2005 and 2013 (CBS, 2015) 


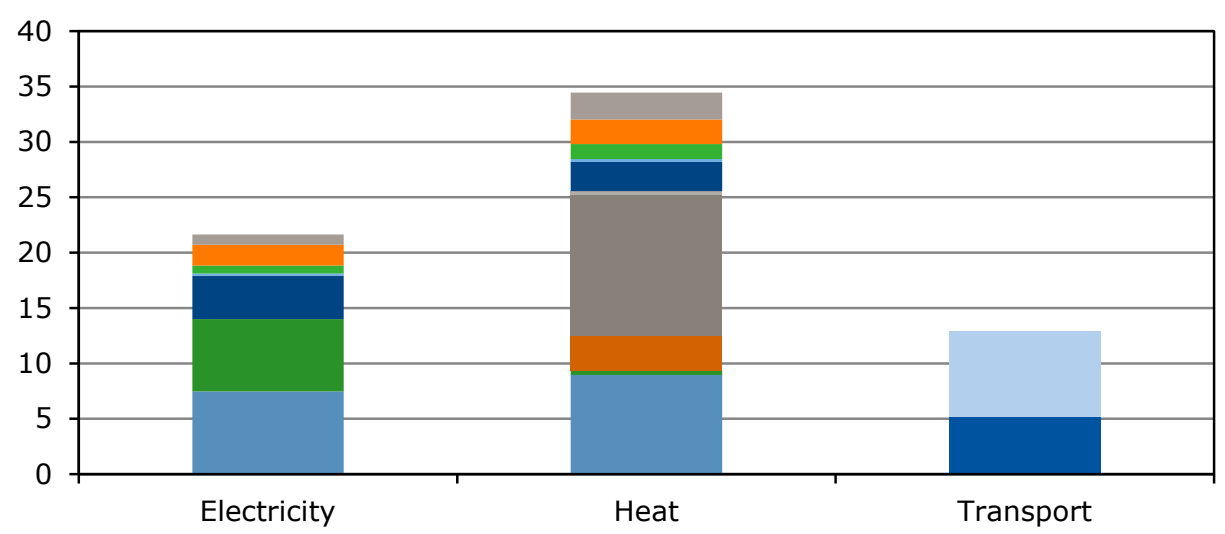

- Municipal waste; renewable fraction - Wood boilers for heat in companies

- Charcoal use, households

Biogas from landfills

Biogas, co-digestion of manure

Biofuels for road transport, total

- Co-firing of biomass in electr. plants Wood stoves in houses, total

- Other biomass combustion, total

Biogas from sewage water purification

Biogas, other

Biogasoline

Figure 5 Gross final consumption of biomass for electricity, heat and transport fuels (PJ), in the Netherlands in 2013 (CBS, 2015)

The Netherlands has an overcapacity of bioethanol and biodiesel plants (Table 7). In 2011, ethanol production capacity was $422 \mathrm{kt}$, while production was $275 \mathrm{kt}$ (i.e. $65 \%$ utilization of operational capacity). ${ }^{5}$ In 2010, biodiesel production in 2010 amounted to $368 \mathrm{kt}$. This corresponds to $48 \%$ utilization or operational capacity in $2010^{6}$. Note that most of the production is exported (mainly renewable diesel from hydrotreated vegetable oil).

Production capacity excludes Cargill's new wheat ethanol plant, which was installed in 2012.

6 Operational capacity in 2010 was 761 kt biodiesel as estimated from start year of operations reported in www.sn-gave.nl 
Table 7

Biofuel production capacity (kt) in the Netherlands in 2010 (RVO, 2015)

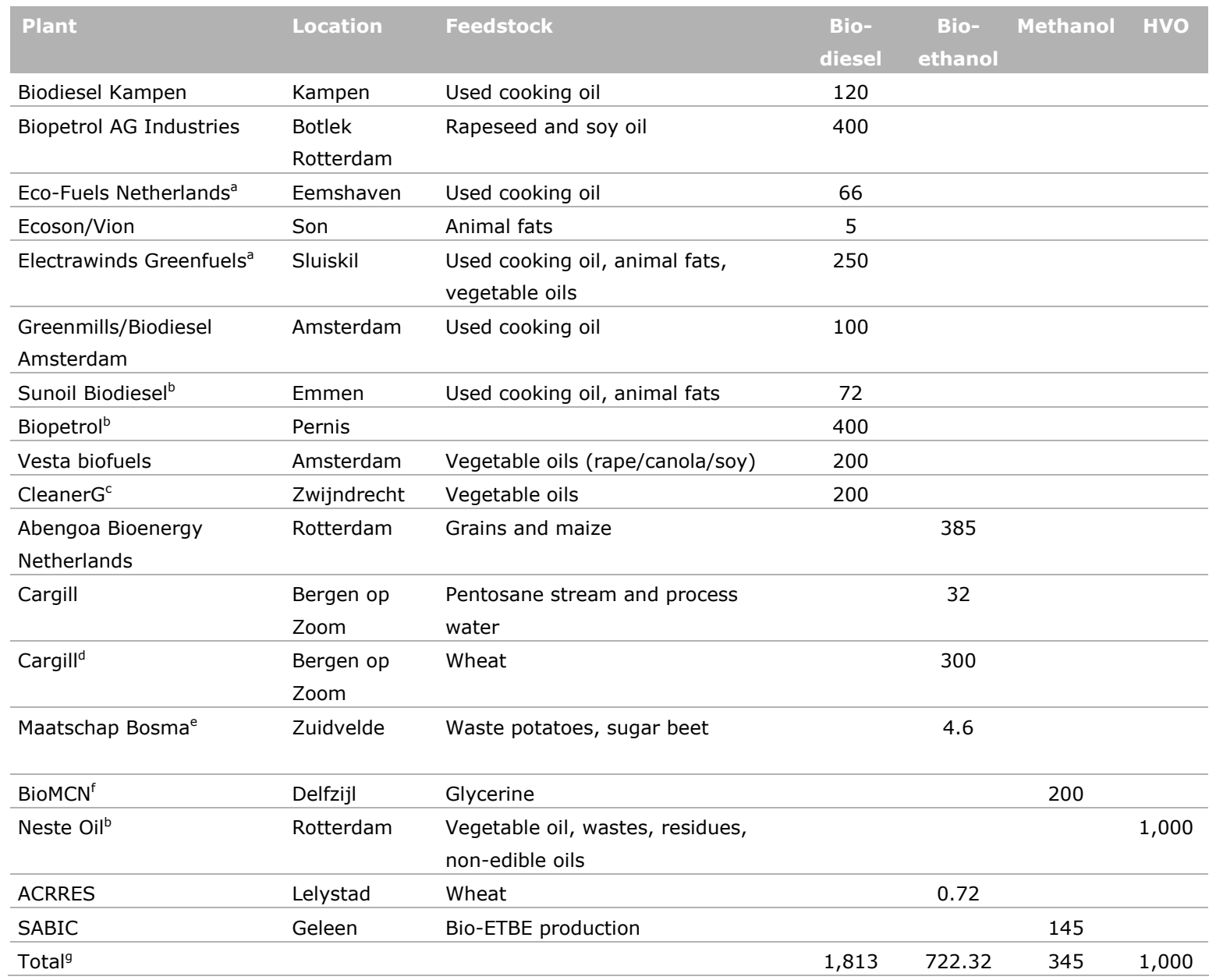

a No longer in operation (Winkel, J., 2015)

b Capacity updated based on Winkel, J. (2015)

c Production on hold (Winkel, J., 2015)

d This facility has been demolished; however, there has been a new factory in the vicinity since 2012 (Winkel, J., 2015)

e Not yet in operation (Winkel, J., 2015)

$f$ Currently, the BioMCN facility does not use glycerine for methanol production

$\mathrm{g}$ Total includes production capacity of all facilities (including those not in operation)

Figure 6 shows the production capacity of bio-based polymers in the Netherlands in 2011. To our knowledge the situation did not change significantly between 2011 and 2014. In 2011, the installed capacity of bio-based polymers in the Netherlands was about $140 \mathrm{kt}$. About $50 \%$ of this capacity was used to produce functional polymers (inks, coatings, etc. by Ecosynthetix). Starch blends accounted for $45 \%$ of installed capacity ( $64 \mathrm{kt}$ by Rodenburg; an earlier study by Shen et al. (2009) indicates $40 \mathrm{kt}$ capacity of starch blends), however, production is not at capacity levels. The remaining $4 \%$ of installed capacity was polylactic acid production by Synbra for polystyrene foam applications (Dammer et al., 2013). 


\section{Production capacity of bio-based polymers [ktonnes/year]}

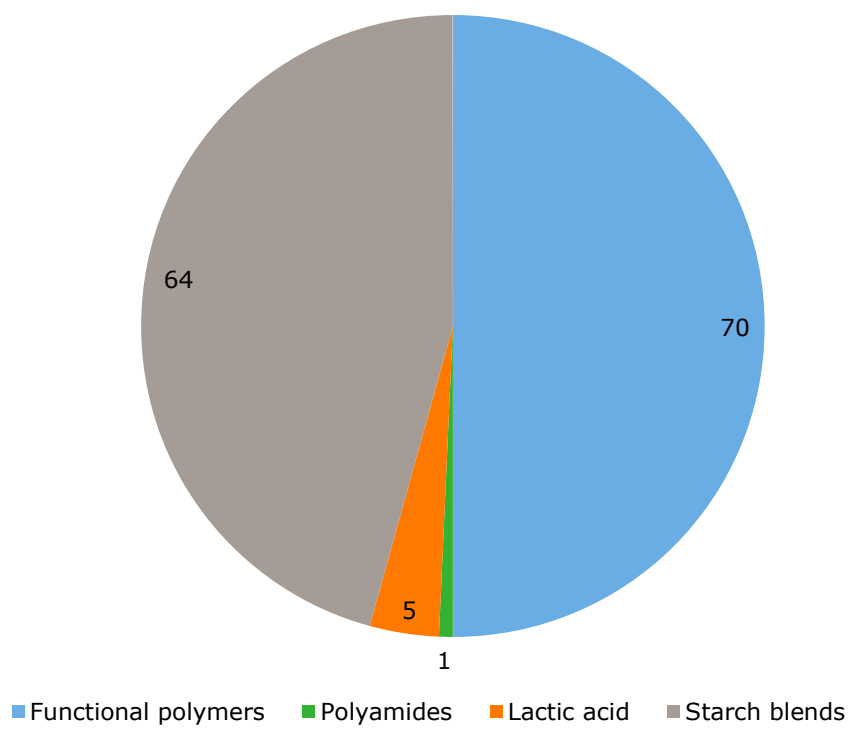

Figure 6 Production capacity of bio-based polymers in the Netherlands in 2011 (Dammer et al., 2013)

\subsubsection{GHG emissions}

Figure 7 presents the historic GHG emissions per sector in the Netherlands from 2005 to 2013. The figure also includes the country's total GHG emission level in 1990, as that is the year compared to which $20 \%$ GHG emission reduction must be achieved by 2020 and $40 \%$ reduction by 2030 . At the national level, the Netherlands has achieved a $10 \%$ emission reduction. Compared to 2005, emission reduction has been achieved by the energy sector $\left(5.5 \mathrm{mt}\right.$ of $\left.\mathrm{CO}_{2}\right)$, industry and construction ( $5 \mathrm{mt}$ of $\mathrm{CO}_{2}$ ) and transport $\left(2.5 \mathrm{mt}\right.$ of $\left.\mathrm{CO}_{2}\right)$. The emission reduction has been achieved in sectors that do not participate in the Emission Trading Scheme (i.e. non-ETS sectors), as emissions from ETS sectors have increased. The contribution to non- $\mathrm{CO}_{2}$ GHG emissions is significant: in 2013, it accounted for approximately $15 \%$ of the total GHG emissions. These originate mainly from agriculture and other non-ETS sectors. Emissions of the former have been relatively constant over the last 9 years; however, reduction of approximately $6.5 \mathrm{mt}$ of $\mathrm{CO}_{2}$ in other non-ETS sectors is noticed. 

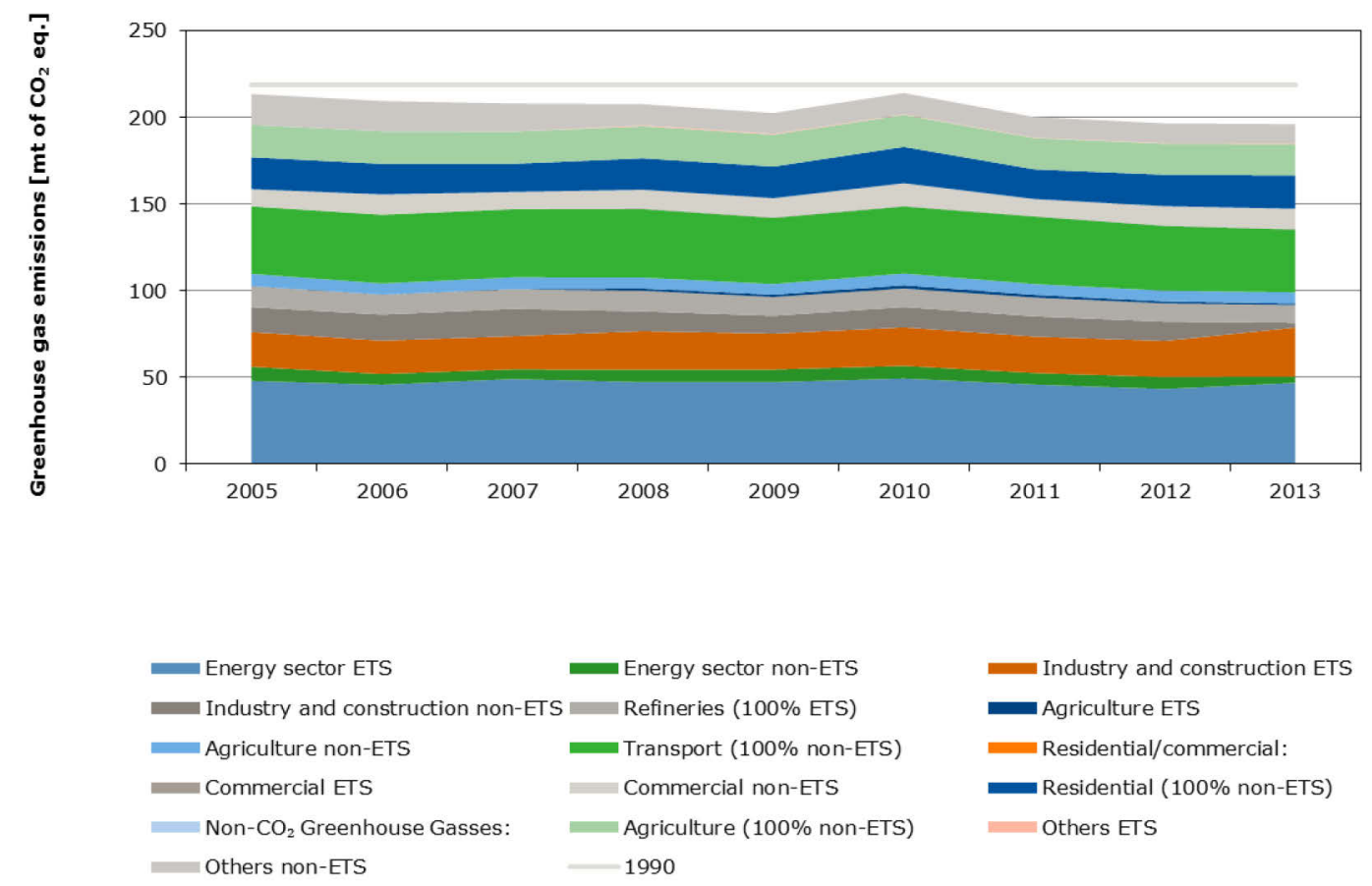

Figure 7 Greenhouse gas emissions in the Netherlands between 2005-2013 (RIVM, 2015)

\subsection{Macroeconomic performance}

This section presents the macroeconomic performance of the bioeconomy complex in 2013 in terms of turnover, value added and employment. Information is provided for the Netherlands as a whole (Section 2.2.2) and for the Dutch provinces (Section 2.2.4). First, the bioeconomy complex accounts for the economic contribution related to activities of the core bioeconomy sectors (see Table 2 in Chapter 1). Second, the complex covers the contribution of other industries and services as far as these result from their business relations with the core bioeconomy sectors (indirect effects). The total of the direct and indirect activities gives an insight into the multiplier effects of the bioeconomy sector (Section 2.2.3). Section 2.1.1 describes how the size of the bioeconomy sectors was determined in this MEV study.

\subsubsection{Share of bio-based technologies in sectors}

Each year, the CBS publishes an Input-Output (IO) table containing detailed financial returns and costs accounts for a broad range of industrial and service sectors in the Netherlands. To make this base IO table useful for agro-food-related analyses and impact studies, LEI disaggregates its agrofood sector into 19 primary subsectors and 20 food and feed processing subsectors (Verhoog, 2014). This better expresses the heterogeneity of the agro-food sector and the different impacts on its subsectors due to, for example, changes in policy or macroeconomic circumstances. Information from the Farm Accountancy Data Network (LEI), the production statistics (CBS) and the labour and environmental accounts (CBS) has been integrated in the base IO table. The resultant agricultural IO table is also a useful tool for describing and measuring the macroeconomic importance of the bioeconomy in the Netherlands. Besides data on turnover ( $€$ millions), value added ( $€$ millions) and employment (labour units), the agricultural IO table provides data on the bioeconomy's energy use (in PJ) and emissions $\left(\mathrm{CO}_{2}, \mathrm{CH}_{4}\right.$ and $\left.\mathrm{N}_{2} \mathrm{O}\right)$.

Figure 8 shows two groups of sectors that comprise the bioeconomy:

- Sectors upstream in the value chain, namely the primary sector (supplier of biomass) and the biotechnology knowledge (R\&D) sector. 
- Sectors downstream in the value chain, namely the users of biomass such as the food \& feed, textile \& clothing, wood, paper \& pulp, chemical, energy, and building sectors.

This distinction fits the one used in a recent RVO study, which monitored the bio-based economy in the Netherlands in 2011 (Kwant et al., 2015).

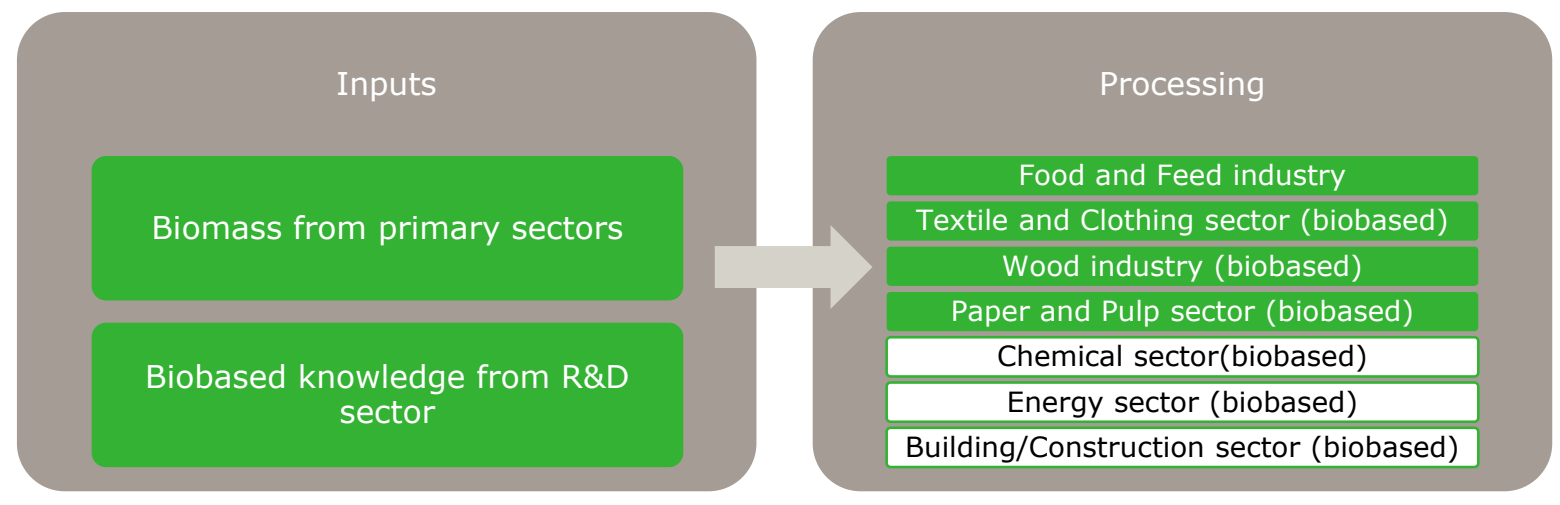

Figure 8 Sectors within the bioeconomy

With regard to the downstream or processing sectors in the value chain, only the contributions from their bio-based production processes contribute to the socioeconomic performance of the bioeconomy. The food and feed industry is traditionally the only sector that is fully $(100 \%)$ based on biomass use. All other downstream sectors in the bioeconomy value chain (right-hand column in Figure 8 ) are only partly bio-based; that applies even to the paper \& pulp sector and the textile \& clothing sector. Although, for example, potato starch is an important bio-based input for the paper \& pulp sector, that sector also uses fossil-based inputs from the chemical sector.

The use of bio-based inputs is relatively high in the paper \& pulp sector and the textile \& clothing sector, and relatively low in the chemical and energy sectors. Despite the current efforts of the chemical and energy sectors to increase their investments in bio-based technologies, these efforts are not yet explicitly visible in the CBS IO tables. Cost and return accounts of the chemical and energy sectors are still expressed as a mixed technology variant. Therefore, a further disaggregation of these mixed technology sectors was needed in order to sort out the contribution of their bio-based and their fossil-based production processes to the economy. To do so, detailed information on intermediate, cross-sectoral costs entries from the agricultural IO table was used to estimate the costs that belong to respectively bio-based and fossil-based production processes of the downstream sectors. First, we derived the following costs factors:

- BioInpCost $(i, j)$ : expenditures on domestically produced inputs and imported inputs from primary sectors and food processing sectors $i$ by bioeconomy sector $j$; and

- FosInpCost $(i, j)$ : expenditures on domestically produced inputs and imported inputs from the oilrelated chemical sectors $i$ by bioeconomy sector $j$.

This cost structure information was then used to divide the downstream 'mixed technology' sector into a bio-based subsector and a fossil-based subsector, again based on financial data from the agricultural IO table. For example, for the chemical sector:

- Bio-based chemical sector: the ratio (BioInpCost(chem)/(BioInpCost(chem)+FosInpCost(chem)) was assessed along the intermediate costs structure of the mixed technology chemical sector.

- Fossil-based chemical sector: the ratio (FosInpCost(chem)/(BioInpCost(chem)+ FosInpCost(chem)) was assessed along the intermediate costs structure of the mixed technology chemical sector.

Column 3 in Table 8 shows the approximated bio-based contents of the downstream bioeconomy sectors based on the described approach. Although the textile \& clothing sector is often considered a traditional bioeconomy sector, its use of fossil-based inputs (like synthetic materials) is rather dominant (around 85\%). The existing bio-based share of the chemical industry in the Netherlands includes a wide variety of products, many of which are high value products (food additives, active 
carbon for filters, rubber products, biological agents, polishing oil, pharmaceutical products, yeast, personal care products, candles, etc.). In the forward looking part of this study, we focused on bulk bio-based polymers that substitute for fossil-based production on a sufficient scale to have a macroeconomic impact. The share of bio-based polymers in total polymers was close to zero in 2013. The bio-based shares in the bioeconomy sectors as derived in Kwant et al. (2015) are quite similar (4 ${ }^{\text {th }}$ column).

\section{Table 8}

Bioeconomy sectors and share of bio-based technologies in their economic value, 2013

\begin{tabular}{|c|c|c|c|}
\hline No. & Bioeconomy sectors & Agricultural IO table & $\begin{array}{l}\text { Monitoring report } \\
\text { (Kwant et al., 2015) }\end{array}$ \\
\hline 1 & Agriculture, forestry and fisheries & $100 \%$ & $100 \%$ \\
\hline 3 & Textile and clothing & $13 \%$ & $1-10 \%$ \\
\hline 4 & Wood industry & $80 \%$ & $85-95 \%$ \\
\hline 6 & Chemical & $4.7 \%$ & $3.7 \%$ \\
\hline 7 & Energy & $3.5 \%$ & $1 \%$ \\
\hline 8 & Building/construction & $11 \%$ & $\mathrm{n} / \mathrm{a}$ \\
\hline 9 & $R \& D$ services & $8 \%$ & $\mathrm{n} / \mathrm{a}$ \\
\hline
\end{tabular}

Source: own calculations based on agricultural IO table (LEI, 2014); Monitoring Bio-based Economy in Nederland in 2014 (Kwant et al., 2015 ).

\subsubsection{Turnover, value added, energy use, emissions and trade balance}

Table 9 presents the contribution of the bioeconomy sectors to the overall Dutch economy in terms of turnover ( $€$ millions), value added ( $€$ millions) and employment (labour units). Table 10shows the extent to which the bioeconomy sectors use energy $(\mathrm{PJ})$ and emit $\mathrm{CO}_{2}\left(\mathrm{CO}_{2}\right.$ equivalents) in comparison to the average Dutch sector.

Findings of Table 9:

- The turnover (i.e. the gross value of output of sector activities) of the total bioeconomy contributes 7.7\% to the Dutch GDP.

- After deducting the intermediate consumption (i.e. the cost of material, supplies and services used to produce final goods or services), the gross value added is obtained, which contributes only $4.9 \%$ to Dutch value added. The high share of intermediate consumption by the food and feed processing sector is down-turning the overall bioeconomy share in Dutch value added.

- Chemical and energy are relatively labour extensive compared to other bioeconomy sectors. 


\section{Table 9}

Turnover and value added ( $€$ millions) and employment (labour units) of bioeconomy sectors in the Netherlands in 2013

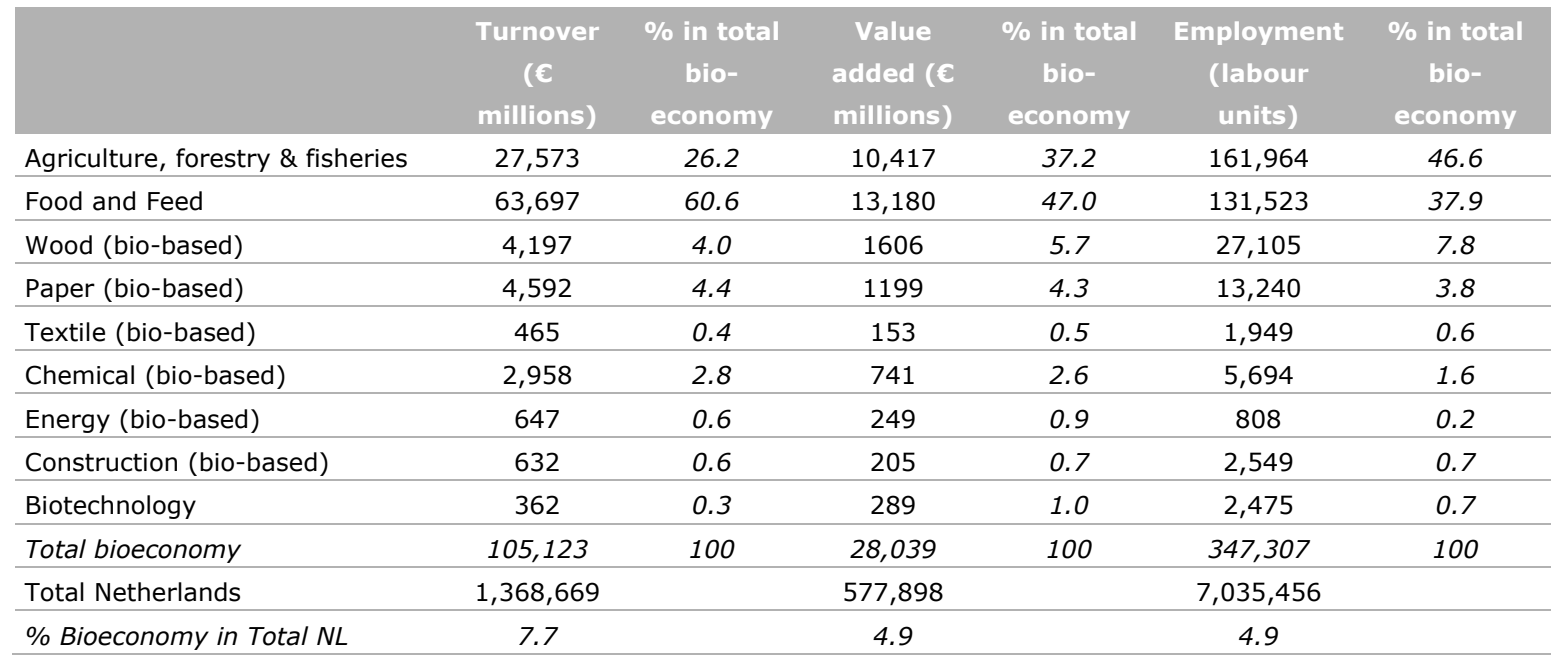

Source: calculations based on agricultural IO table, 2013

Findings of Table 10:

- The chemistry, energy and primary sectors are relatively energy use intensive compared to other bioeconomy sectors.

- The total bioeconomy uses relatively more energy and creates more emissions than the average Dutch sector.

\section{Table 10}

Energy use (TJ) and Emissions (million $\mathrm{CO}_{2}$ equivalents) of bioeconomy sectors in the Netherlands in 2013

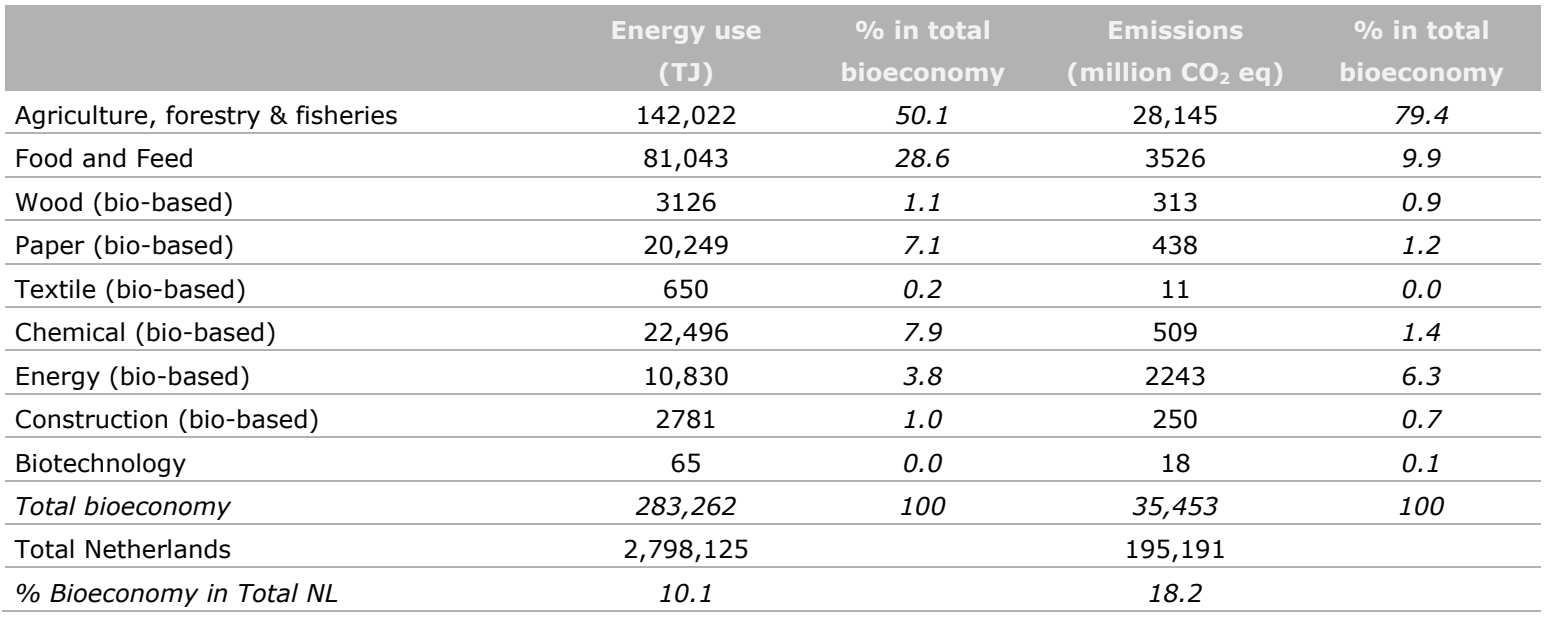

Source: calculations based on agricultural IO table, 2013.

Figure 9 shows the shares of the distinguished bioeconomy sectors in the overall bioeconomy in terms of turnover, value added and employment. With a share of $80-85 \%$ of the total, the contribution of the primary, food and feed sectors is quite dominant. Figure 10 and Figure 11 summarize the turnover, value added and employment for each of the downstream bioeconomy sectors, except for the food \& feed sector. 


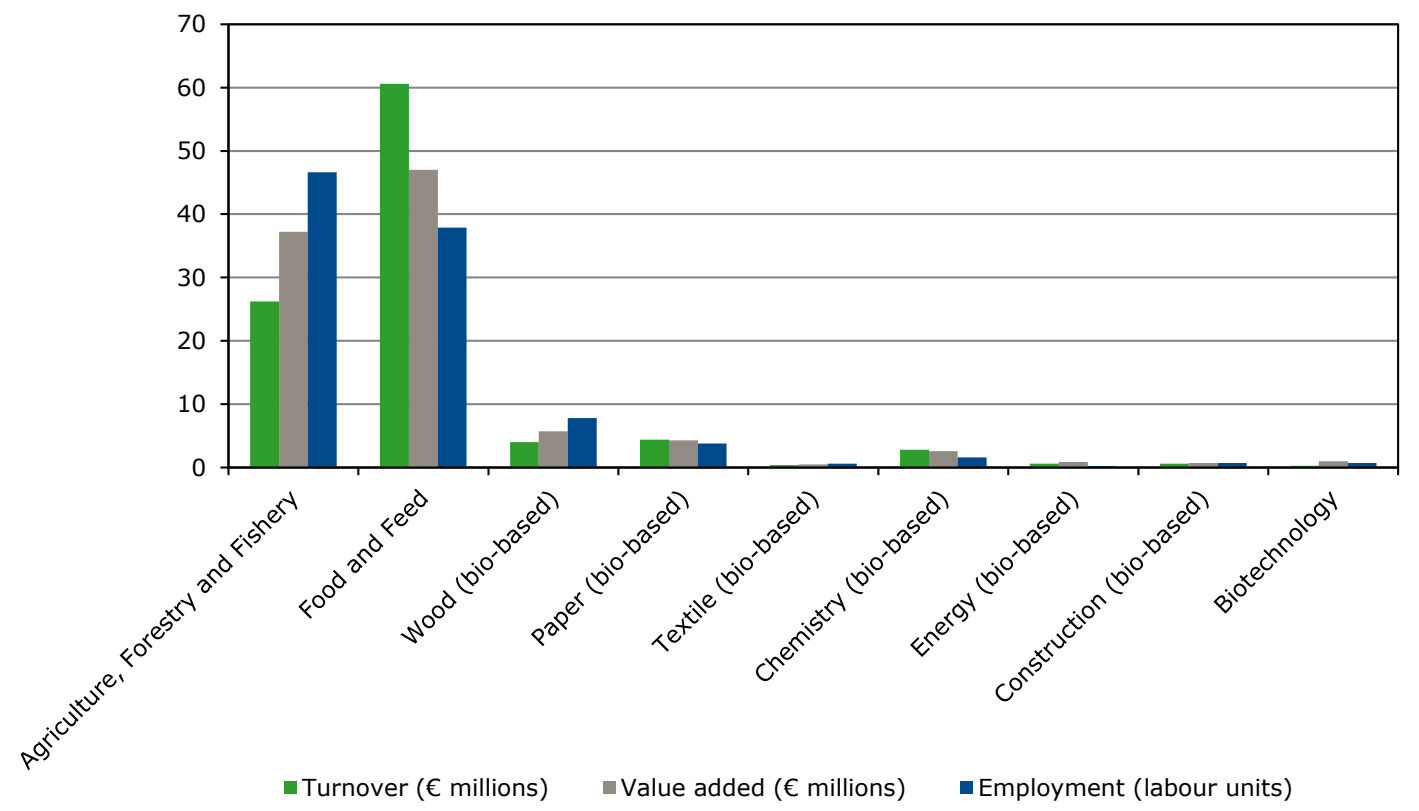

Figure 9 Contribution of bioeconomy sectors to total bioeconomy (\%) in the Netherlands in 2013

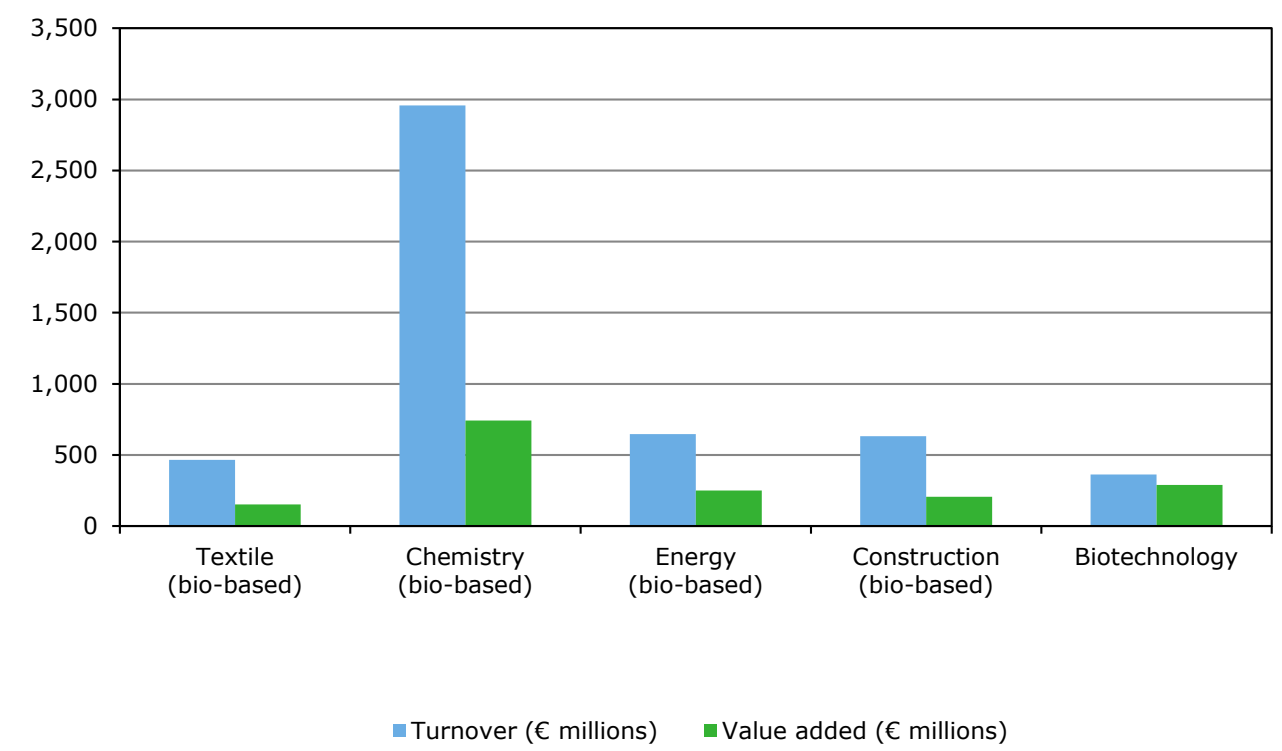

Figure 10 Turnover and value added ( $€$ millions) in new bioeconomy sectors in the Netherlands in 2013 


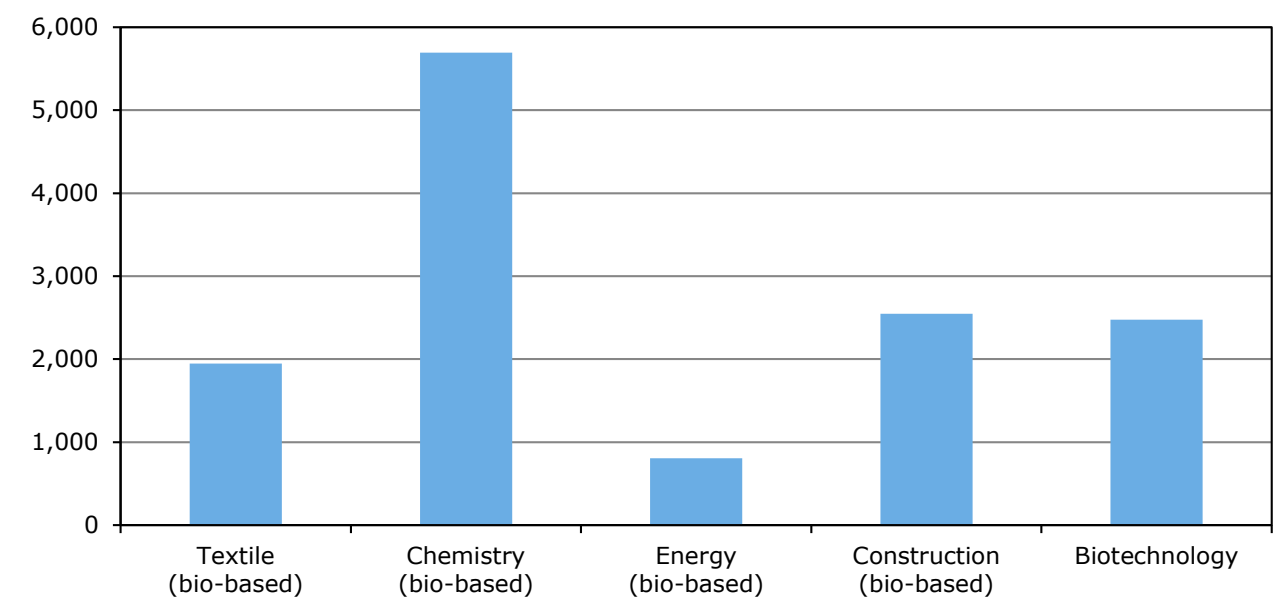

Figure 11 Employment (labour units) in new bioeconomy sectors in the Netherlands in 2013

\subsubsection{Multipliers of the bioeconomy}

The analysis in the previous section focussed on the direct impact of the bioeconomy subsectors on the Dutch macroeconomy. The indirect effects of these bioeconomy sectors can be calculated by applying the IO analysis technique. Indirect effects (a synonym for spill-over effects) capture the creation of extra value added and extra employment that occurs in other sectors due to activities that have been initiated in the bioeconomy sectors (e.g. bank and computer services). Moreover, the activities due to the distribution of bioeconomy products to intermediate and final users are also regarded as indirect effects of the bioeconomy. In other words, indirect or spill-over effects of the bioeconomy correspond to the additional value that is generated elsewhere in the region due to activities initiated in the bioeconomy sectors.

\section{Box 1. Multiplier effects in Section 2.2.3 versus indirect effects in Section 4.2}

The multiplier effect is the increase in national income and consumption that results from an increase in spending in an industry. This increase is greater than the initial amount spent in that industry. For example, if a paper industry builds a new factory, it will employ construction workers and their suppliers as well as those who work in the new paper factory (this is the direct effect). Indirectly, the new paper factory will stimulate employment in laundries, restaurants and service industries in the factory's vicinity. Based on the agricultural IO table, we calculated the multiplier effects of the bioeconomy sectors in the Netherlands in 2013 (Section 2.2.3). The multiplier is derived by taking the ratio between the total (direct and indirect) effect of a bioeconomy sector and its direct effect. In this case, indirect effects are always positive.

We calculated the indirect effects for the regional economy from investments in bio-based sectors differently (Section 4.2). MAGNET projects the size of the new bio-based sectors in 2030, which can be compared to their size in the reference year. This is regarded as the direct effect of these new bio-based sectors. However, this might lead to competition effects due to price and volume changes across sectors. MAGNET calculates the indirect effects of the new bio-based sectors by comparing the indicator values (e.g. turnover, value added and employment) of all other sectors in the economy between 2015 and 2030. In this case, the indirect effects can be both positive and negative. 
Table 11 presents the direct and indirect contribution of the bioeconomy subsectors to the overall Dutch economy in terms of turnover, value added and employment, and Table 12 presents the same for energy use and $\mathrm{CO}_{2}$-equivalents emissions. Compared with what the bioeconomy sectors provide on their own (Table 10), the percentage contributions to national turnover, value added and employment are almost doubled.

\section{Table 11}

Direct and indirect turnover ( $€$ millions), value added ( $€$ millions) and employment (labour units) of bioeconomy sectors in the Netherlands in 2013

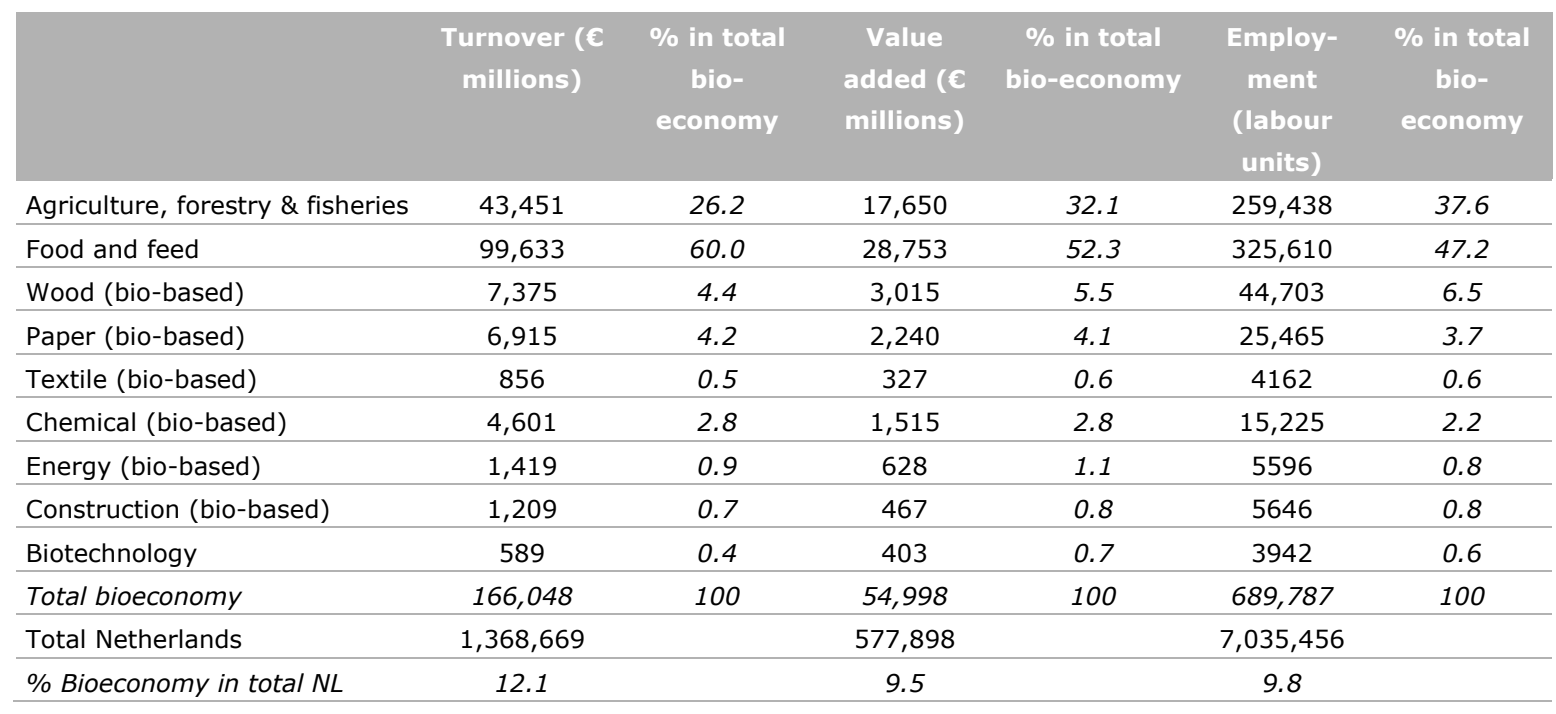

Source: calculations based on agricultural IO table, 2013.

\section{Table 12}

Direct and indirect energy use (TJ) and emissions (million $\mathrm{CO}_{2}$ equivalents) of bioeconomy sectors in the Netherlands in 2013

\begin{tabular}{|c|c|c|c|c|}
\hline & $\begin{array}{c}\text { Energy use } \\
\text { (TJ) }\end{array}$ & $\begin{array}{l}\% \text { in total } \\
\text { bioeconomy }\end{array}$ & $\begin{array}{c}\text { Emissions } \\
\left.\text { (million } \mathrm{CO}_{2} \mathrm{eq}\right)\end{array}$ & $\begin{array}{l}\% \text { in total } \\
\text { bioeconomy }\end{array}$ \\
\hline Agriculture, forestry \& fisheries & 169,635 & 45.1 & 30,048 & 72.8 \\
\hline Wood (bio-based) & 7728 & 2.1 & 592 & 1.4 \\
\hline Paper (bio-based) & 23,523 & 6.3 & 630 & 1.5 \\
\hline Chemical (bio-based) & 25,196 & 6.7 & 667 & 1.6 \\
\hline Energy (bio-based) & 12,229 & 3.2 & 2,328 & 5.6 \\
\hline Construction (bio-based) & 3,686 & 1.0 & 297 & 0.7 \\
\hline Biotechnology & 371 & 0.1 & 36 & 0.1 \\
\hline
\end{tabular}

Source: calculations based on agricultural IO table, 2013.

The ratio between the total (direct and indirect) effects of the bioeconomy sectors and its direct effects can be regarded as a sector multiplier. Figure 12 depicts multipliers for value added and employment of each bioeconomy sector. Especially the employment multiplier for the energy sector is significant, which is due to the relatively high labour productivity of this sector (the energy sector is capital intensive). On the one hand, the number of people who are directly employed in the energy sector is relatively small. On the other hand, this sector generates a relatively large number of jobs elsewhere 
in the region, such as in inputs providing sectors and in sectors that distribute energy to intermediate users and end-users.

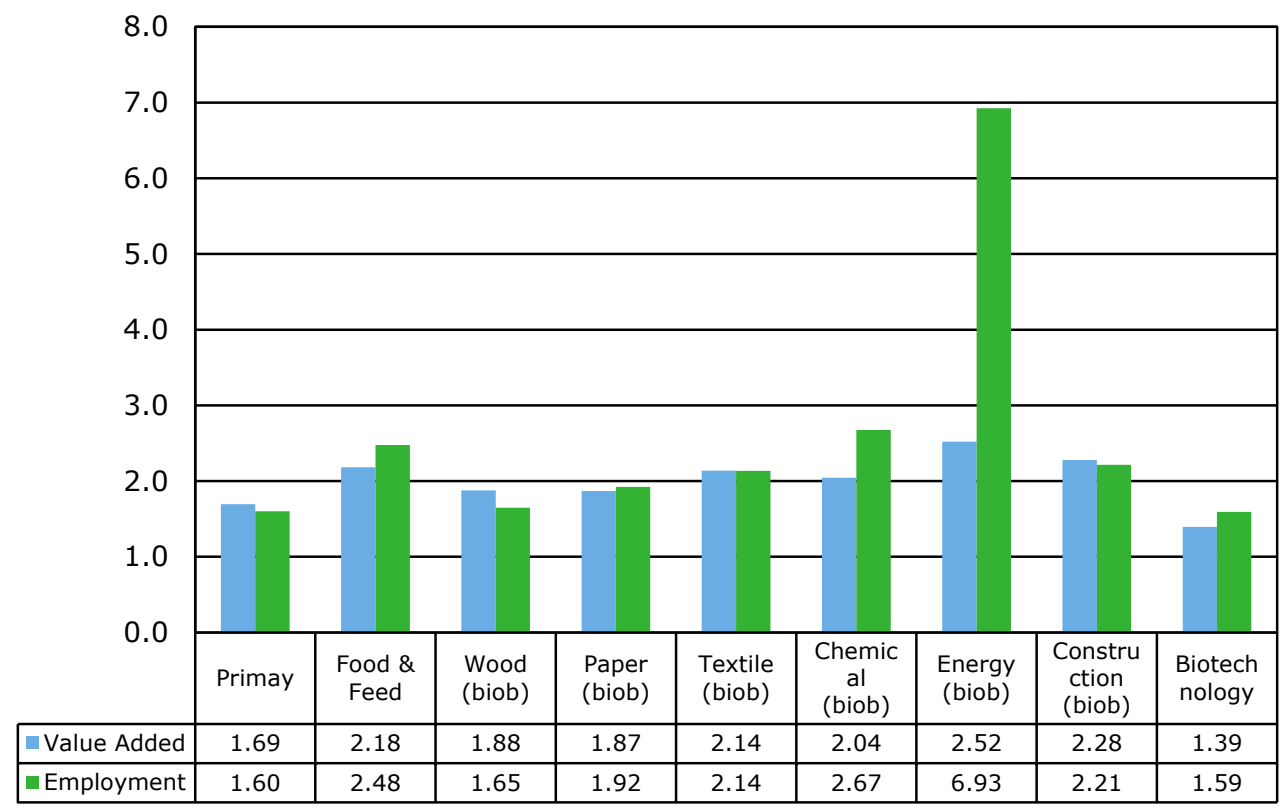

Figure 12 Multipliers for value added and employment of bioeconomy sectors in the Netherlands in 2013

Findings with regard to the multipliers in Table 11, Table 12 and Figure 12:

- The value added (i.e. revenue minus outside purchases) of the total bioeconomy accounts for $9.5 \%$ of the total Dutch value added.

- The chemical and energy sectors are relatively labour extensive compared to other bioeconomy subsectors.

- The chemical, energy and primary sectors are relatively energy use intensive, compared to other bioeconomy subsectors.

- The overall bioeconomy uses relatively more energy (PJ per euro value added), and provides relatively more emissions ( $\mathrm{CO}_{2}$ equivalents per euro value added) than the average Dutch sector; this is due to the relatively high share of the primary sector.

- Multipliers for the chemical and energy sectors are relatively high, meaning that the production of chemical or energy products generates relatively more additional activities (which are not necessarily bio-based) in the rest of the economy than the other bioeconomy sectors.

- The size of the employment multiplier for energy sector is high, which relates to the indirect employment that is generated with the distribution/transport of gas to users (industry and consumer).

\subsubsection{Bioeconomy in Dutch provinces}

Table 13 addresses the spread of value added and employment (in terms of \%) in the national bioeconomy over the provinces. 
Table 13

Contribution of provinces to Dutch value added and employment (\%), 2013

\begin{tabular}{|c|c|c|}
\hline Province & $\begin{array}{l}\% \text { in value added of Dutch } \\
\text { bioeconomy }\end{array}$ & $\begin{array}{l}\% \text { in employment of Dutch } \\
\text { bioeconomy }\end{array}$ \\
\hline Groningen & 5.1 & 4.2 \\
\hline Drenthe & 3.1 & 3.4 \\
\hline Overijssel & 6.6 & 7.8 \\
\hline Flevoland & 3.0 & 3.0 \\
\hline Utrecht & 3.7 & 3.9 \\
\hline North Holland & 9.1 & 10.0 \\
\hline South Holland & 18.9 & 17.1 \\
\hline
\end{tabular}

Source: calculations based on agricultural IO table; LISA employment data.

As shown in Figure 13, the province of North Brabant contributes most ( $€ 7.7 \mathrm{bn})$ to the overall value added of the bioeconomy in 2013, followed by South Holland ( $€ 5.4 \mathrm{bn}$ ) and Gelderland ( $€ 3.5 \mathrm{bn})$. In terms of employment (Figure 14), North Brabant is also the most important $(67,400$ jobs) province, followed by South Holland (59,600 jobs) and Gelderland (50,700 jobs). Table 13 and Figure 13 show that the value added of the total bioeconomy is lowest in Drenthe, Utrecht and Zeeland, and that the size of employment of the bioeconomy is lowest in Zeeland and Flevoland.

Finally, Figure 15 presents the location of biochemical and bioenergy sectors in Dutch provinces. The chemical industry and its research institutions are mostly located in North Brabant (i.e. Green chemical campus in Bergen op Zoom, Corbion), South Holland (i.e. Rotterdam, Delft) and Limburg (i.e. DSM, Chemelot in Sittard/Geleen). The energy sector is more equally spread over the provinces.

Figure 16 shows the location of the bio-based paper and pulp sector and the bio-based textile and clothing sector. The paper and pulp sector is traditionally mainly located in Gelderland (Veluwe), North Brabant, Groningen and Limburg, as those provinces produce such raw materials as forestry, wood and arable crops. The textile sector is significantly present in the North Brabant (Langstraat) and Overijssel. 


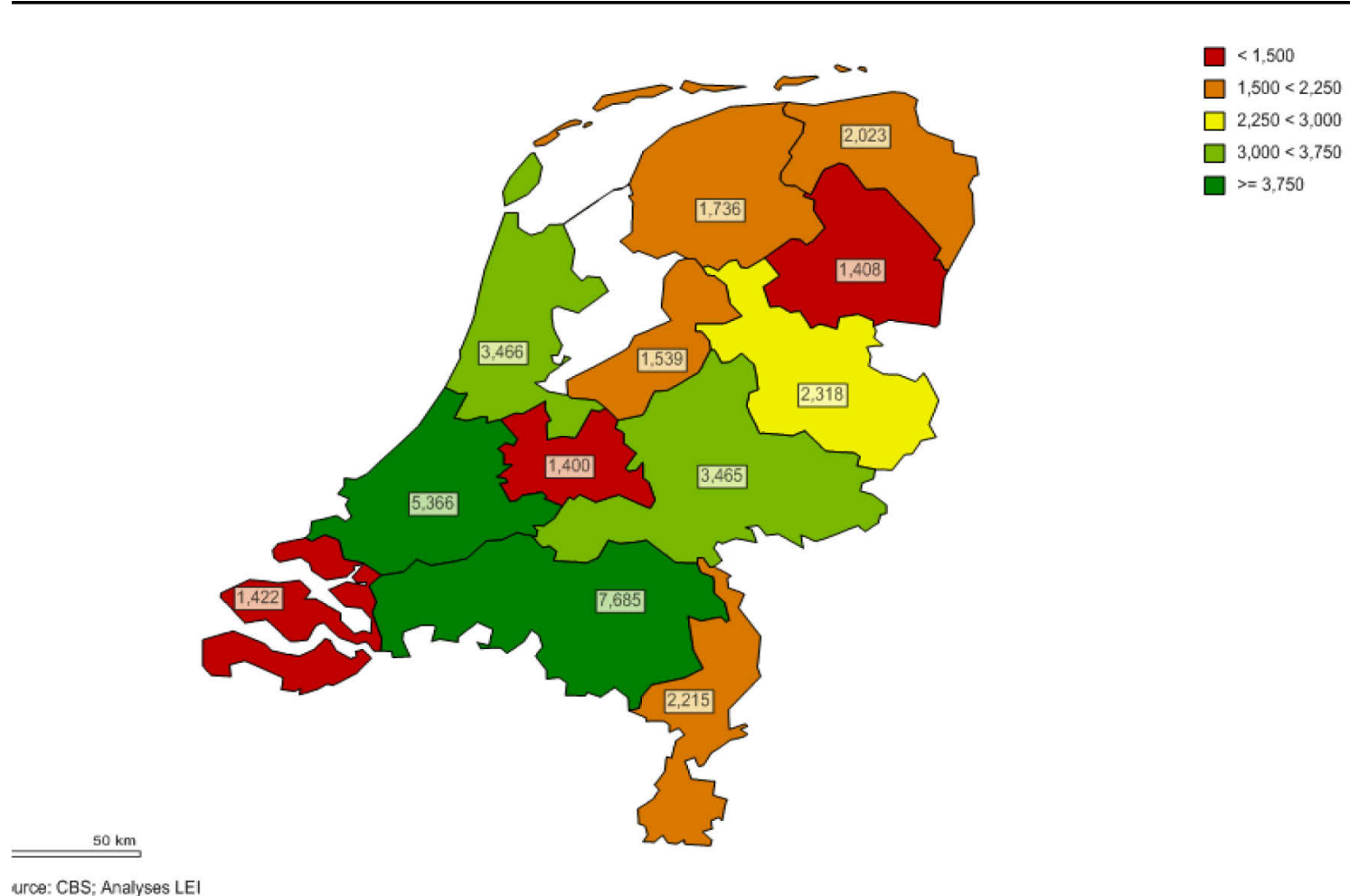

Figure 13 Value added ( $€$ millions) of the bioeconomy per province, classified to provinces with a large (green) or small (red) bioeconomy, 2013

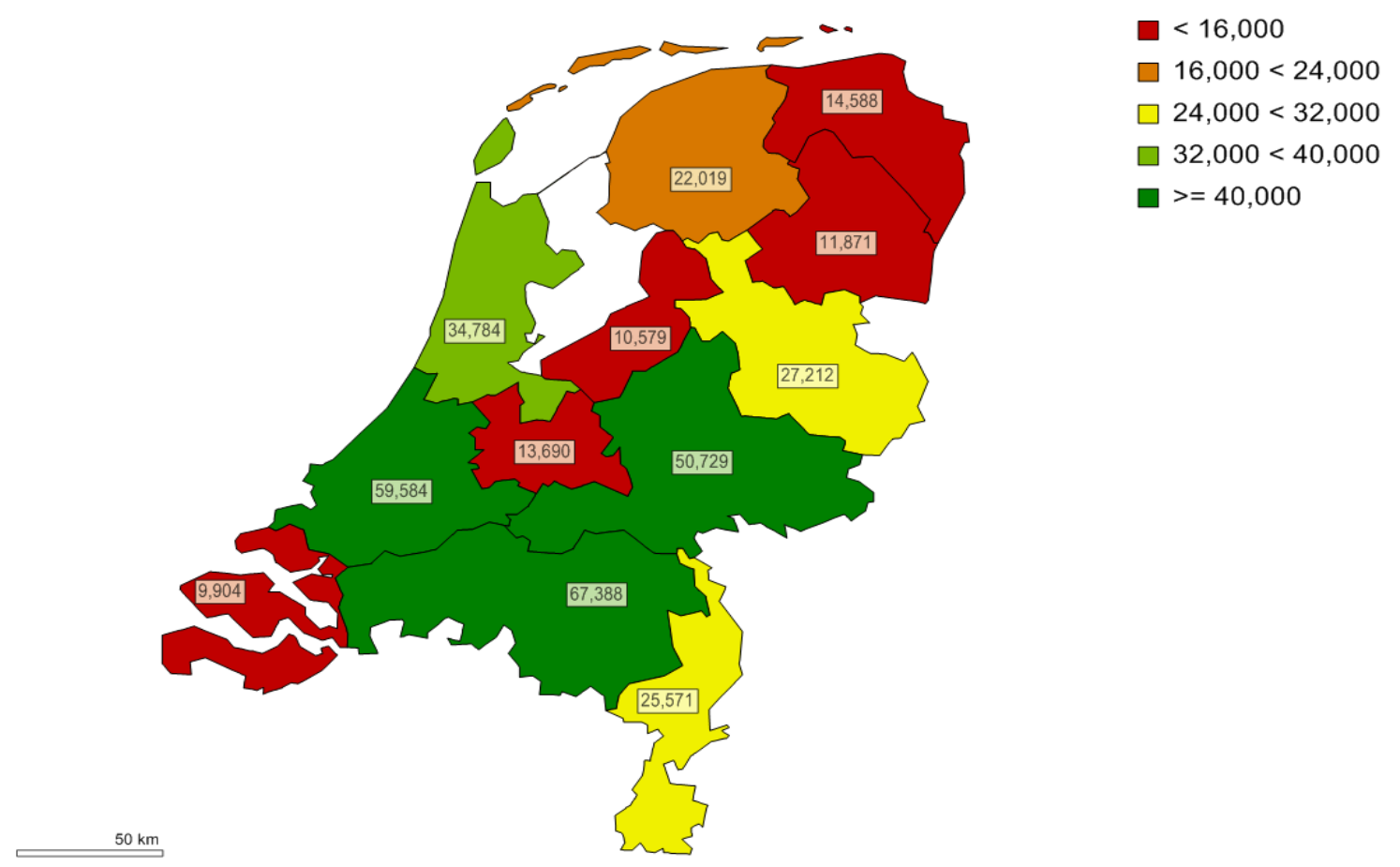

Source: CBS; Analyses LEI

Figure 14 Employment (labour units) of the bioeconomy per province, classified to provinces with a large (green) or small (red) bioeconomy, 2013. 


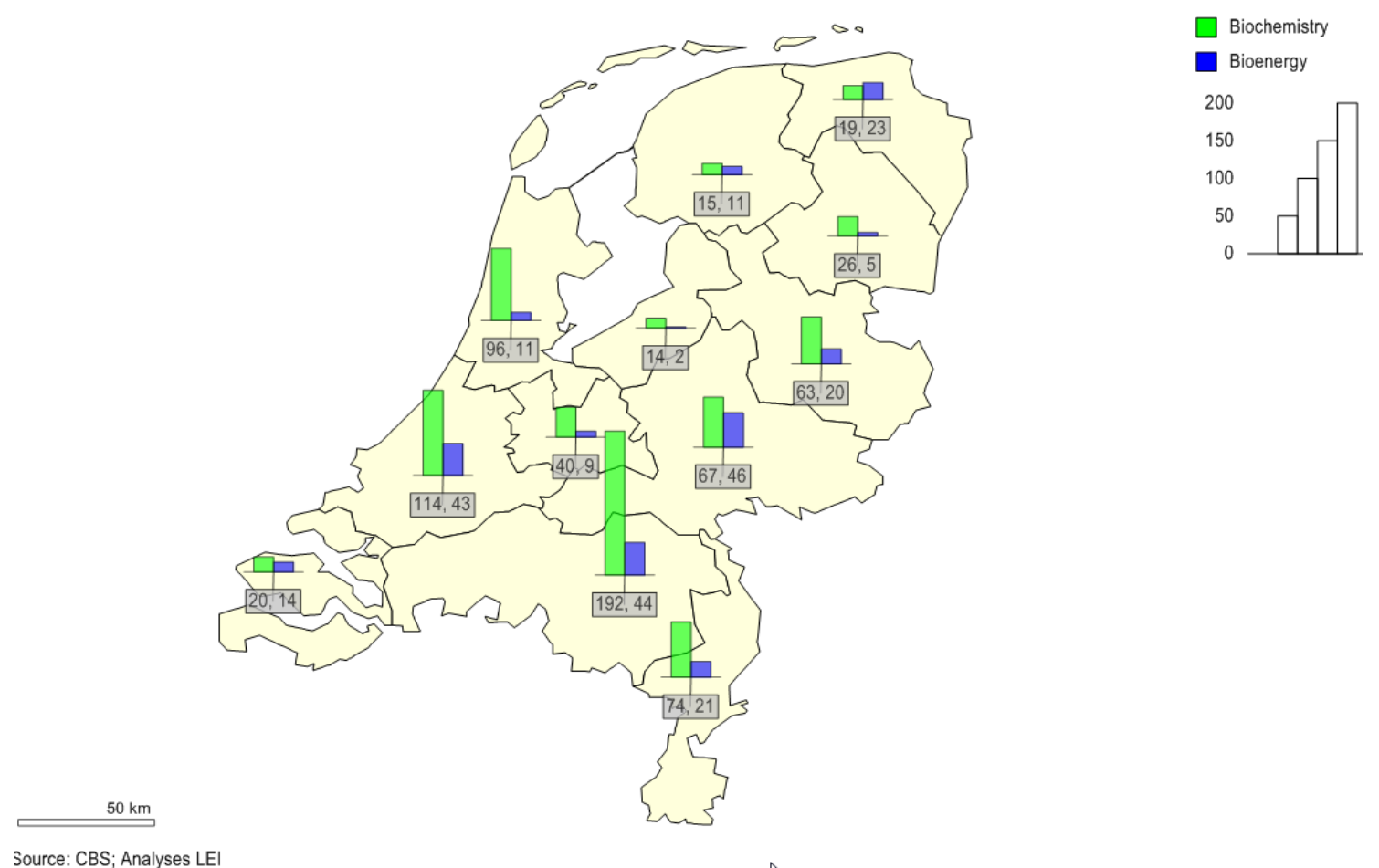

Figure 15 Value added ( $€$ millions) of bio-based chemical and energy sectors in Dutch provinces in 2013
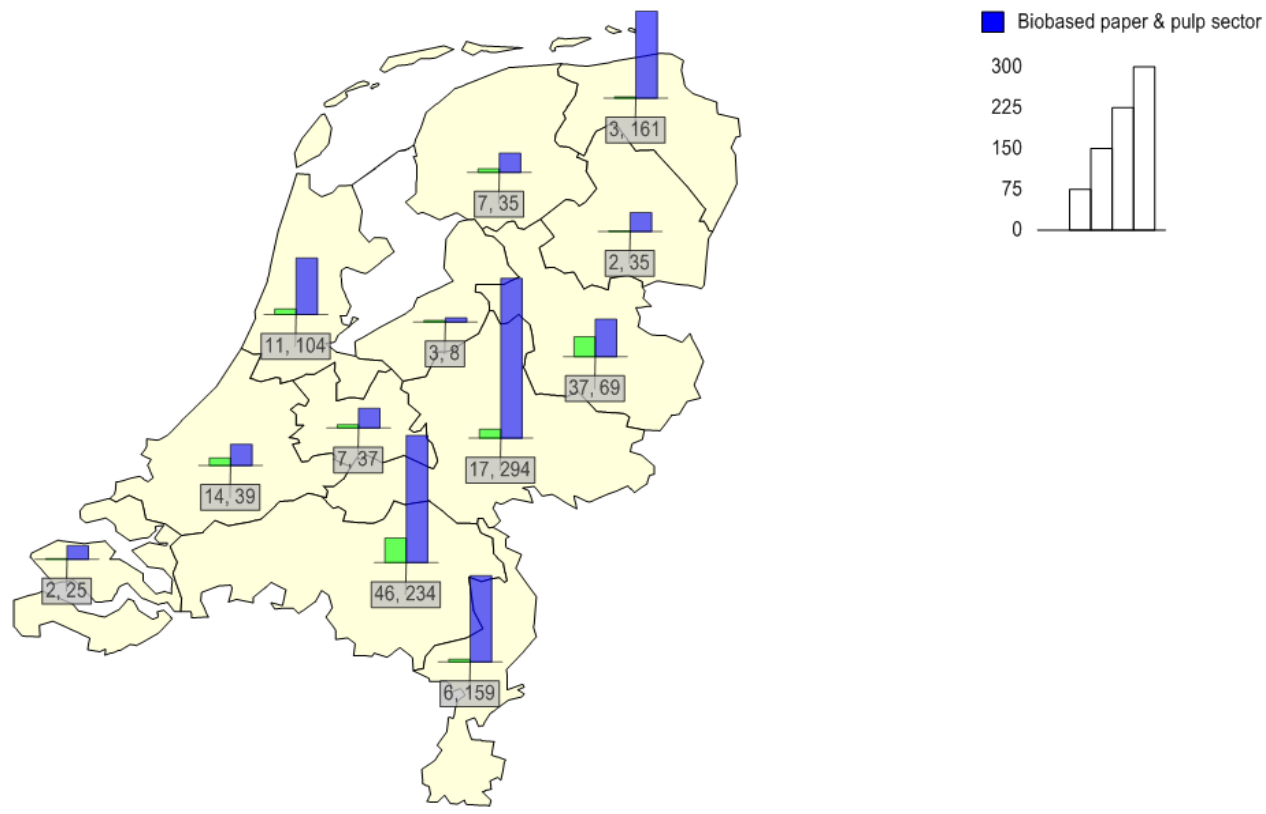

Source: CBS; Analyses LEI

Figure 16 Value added ( $€$ millions) of bio-based paper \& pulp and textile sectors in Dutch provinces 


\section{Method}

\subsection{General overview}

The method applied in this study was based on the MEV I study and consisted of two parts: a bottomup study based on technological expectations and a top-down analysis using the advanced multisector and multi-region macroeconomic computable general equilibrium (CGE) model MAGNET. In the MEV II study the methodology was enhanced in the bottom-up study by the use of the detailed cost optimization MARKAL-NL-UU model of the energy and chemical sector of the Netherlands (Section 3.3) and in the MAGNET model by the disaggregation of bioeconomy sectors, endogenous GDP and endogenous bioeconomy developments (Section 3.4).

The bottom-up component examined the details of the markets that can potentially use biomass (e.g. energy, transport, chemicals), the cost structures of biomass-using technologies, technology improvement rates, the energy carriers into which biomass is converted, the expected prices of raw materials and the cost of the conversions, the GHG emissions and the amount of available biomass. More detailed information for the bio-based applications in the energy, chemical and biofuel sectors was based on a literature review and company experts (e.g. Corbion, DSM, Essent).

The top-down macroeconomic impact study was carried out to calculate the effects of increased biomass use on the economy. It looked at GDP developments, the growth of economic industries (revenue, value added), the required amount of subsidies, the effects on the trade balance, employment, etc. Compared to the MEV I study, more detailed data on biomass value chains in the energy, biofuel and chemical sectors was implemented in MAGNET, based on cost structures, input and output prices provided by MARKAL-NL-UU, literature and expert information. Furthermore, GDP developments and bio-based shares in transport fuels, energy and chemicals were endogenously determined and not fixed or taken from another source, as was done in MEV I.

The detailed bottom-up modelling of biomass conversion options with MARKAL-NL-UU in combination with the multisector and multi-country macroeconomic model MAGNET help to better understand the potential impact of developing a bioeconomy on the Dutch macroeconomy. This toolkit also gave insight into required technological developments and the avoided fossil energy use and GHG emissions between now and 2030.

The two modelling components were used in conjunction. In essence, the interaction was in one direction, namely the results and input data of the bottom-up MARKAL-NL-UU model in terms of rate of technological development to 2030, cost structures and selection of promising technologies were incorporated in the top-down MAGNET model. An exception is that in a sensitivity analyses, the development of the chemical sector of MAGNET was incorporated in the MARKAL-NL-UU model (Section 5.1.6).

Both the bottom-up and the top-down analyses were carried out using a two-axes scenario approach similar to the MEV I (Section 3.2):

- The openness of markets and consequently the supply and trade of biomass and thereby the price and supply of biomass (Section 3.2.1).

- The rate of technical change, which is especially important for the competitiveness of advanced and innovative technologies (Section 3.2.2).

Energy and climate change policies, as well as demographic and macroeconomic developments, are considered key drivers behind the potential development of the bioeconomy in the Netherlands.

Associated assumptions were similarly implemented in the conducted scenarios (see Section 3.2.3). 
Macro-economy population (SSP2); GDP (SSP2) determines tech change in pre-simulation*

EXogenous for
MAGNET and
MARKAL (2015-30)
Policy: RED, $\mathrm{CO}_{2}$ prices (IEA),
Dutch energy agreement
World prices:
energy
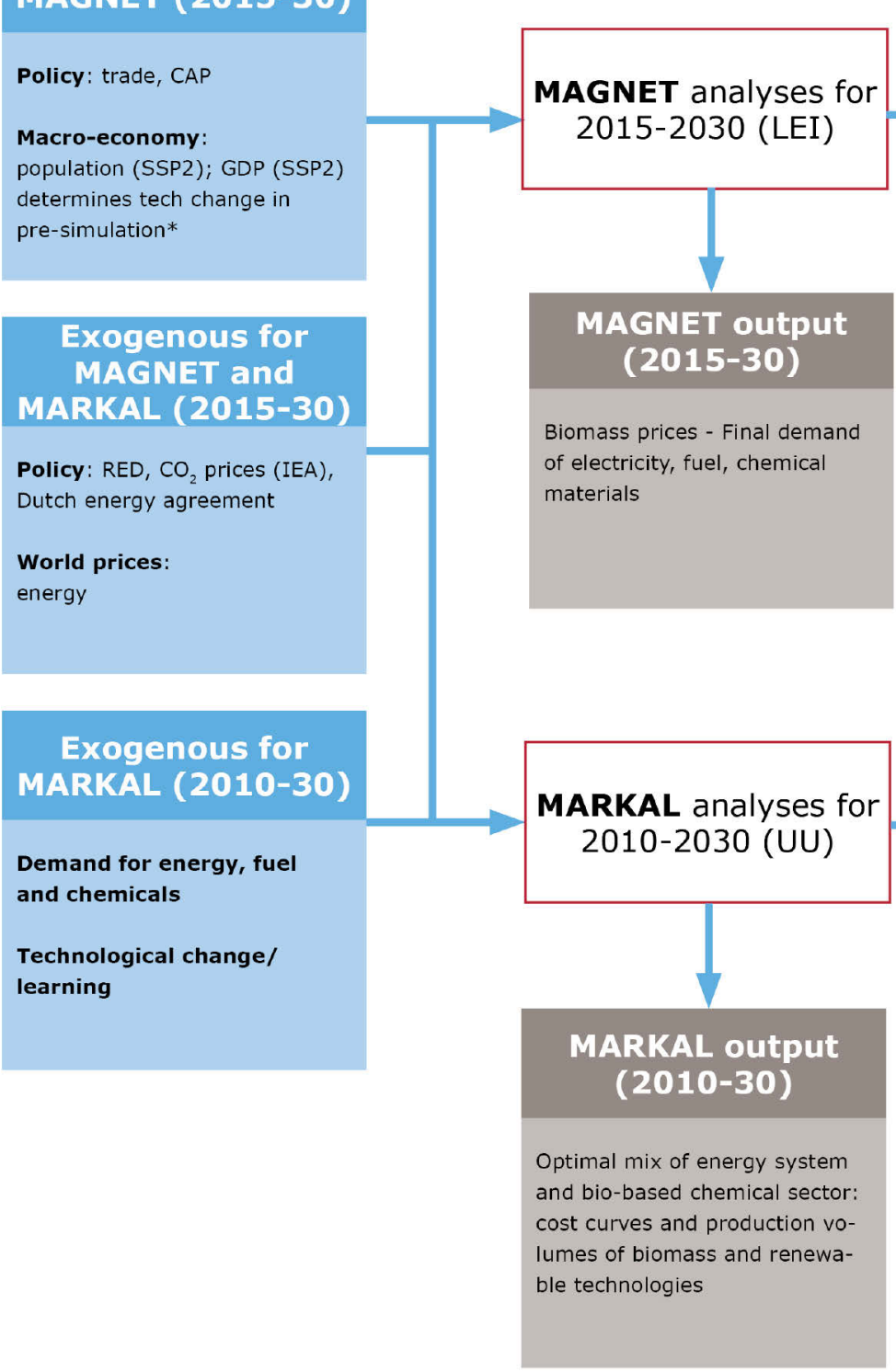

Figure 17 Model structure of MAGNET and MARKAL-NL-UU used in the MEV II study * In pre-simulation, GDP was exogenous and the difficult to measure technical change was endogenously determined. In the main scenario this was reversed to obtain endogenous GDP (see Meijl et al., 2016).

\subsection{Scenarios}

The macroeconomic impacts of the bio-based economy in the Netherlands were investigated using a scenario approach: starting from the existing situation, uncertainties in development were examined using a two-axes scenario approach (Figure 18). The two scenario variables that were considered are similar to the scenario axis used in the MEV I study, namely the openness of markets (see Section 3.2.1) and the rate of technical change (Section 3.2.2). Crucial is that national and international climate change and renewable energy policies were considered in all scenarios, because these are key drivers behind the production and use of biomass (see further Section 3.2.3). 


\section{Intra and extra European trade}

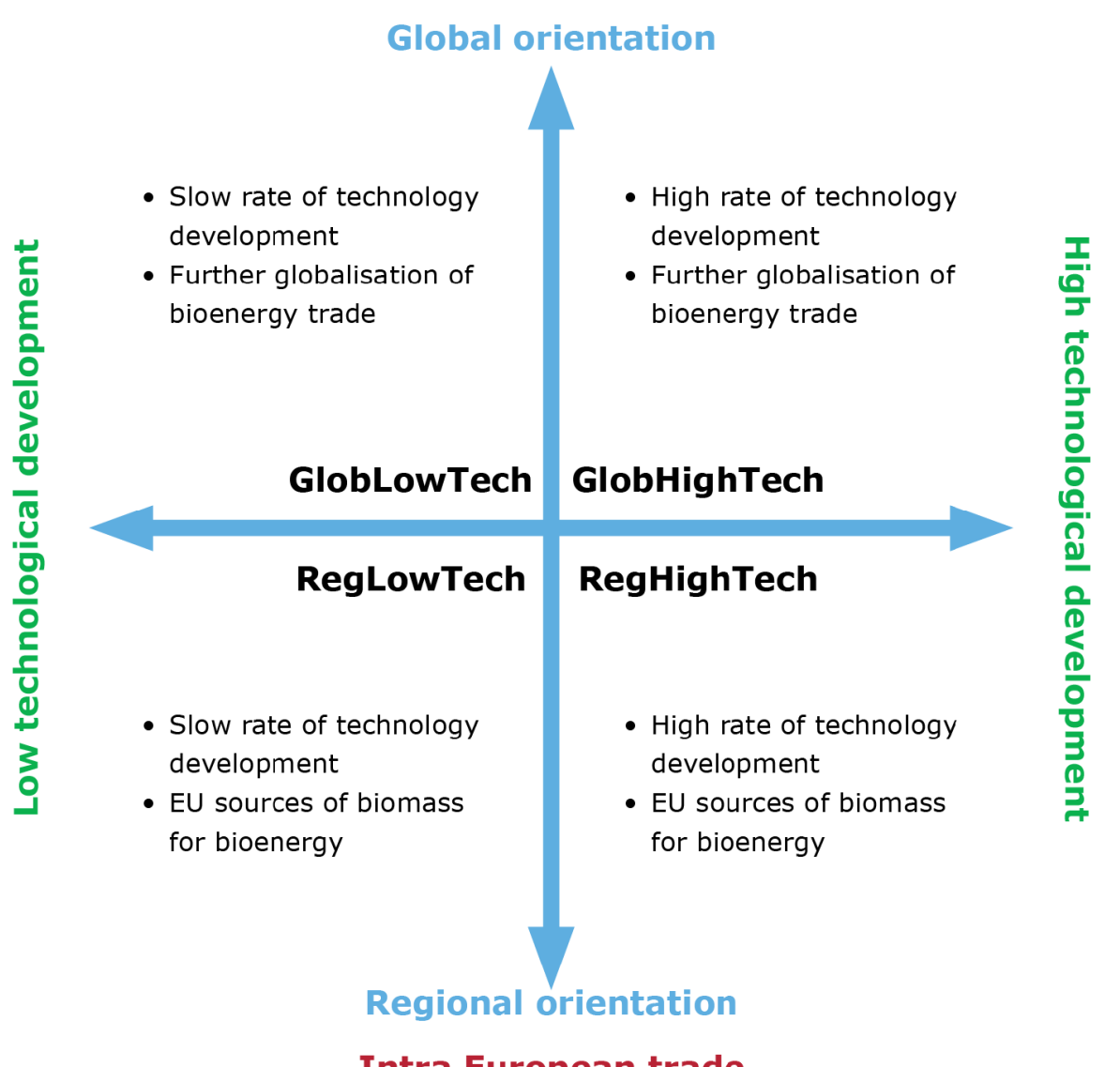

Figure 18 Four scenarios in MEV II

\subsubsection{Openness of markets: global versus regional biomass supply}

The large shift from traditional to modern uses of biomass in the last decade has resulted in rapid developments in the trade of both liquid and solid biomass (Lamers et al., 2014; Lamers et al., 2014). It is expected that the international biomass trade will continue to grow as a result of the increasing demand for modern uses of bioenergy. It is, however, uncertain how this trade will develop. The uncertainty in future trade development was translated in a regional scenario (Reg) and a global scenario (Glob). The 'Reg' scenario assumes that the EU supports renewable energy and bio-based chemicals only if produced from available EU resources; extra-EU imports of biomass for bioenergy are thus restricted. Although such a development may conflict with WTO rules, it could be applied via strict sustainability criteria and greenhouse gas reduction requirements for market access (Lamers et al., 2014). The 'Glob' scenarios assume that trade barriers for biomass will be mitigated by, for example, the implementation of standardization systems and certification systems that guarantee the sustainability of biomass supply. In the Glob scenario, the global trade of biomass will grow rapidly and the Netherlands could become a trade hub for intercontinental biomass imports into the EU.

Possible drivers of the 'Reg' scenario:

- Large domestic demand in regions that are currently supplying sustainable biomass to the EU reduces the export potential, e.g. in the USA.

- Renewable energy support in the EU shifts to the domestic supply of biomass to ensure the sustainability of supply, reduce dependence on non-EU countries, and stimulate rural development and create employment.

- Increased global competition for traded biomass resources reduces the incentives to meet (strict) EU criteria (e.g. exclusion of primary forestry biomass due to carbon debt issues). 
Possible drivers of the 'Glob' scenario:

- Development in logistic infrastructure to mobilize biomass (at low cost), biomass becomes a tradable energy commodity.

- Developments in agriculture and forestry increase the export potential in (low cost) supply regions.

- Standardization of sustainability criteria.

\subsubsection{Technical development: LowTech versus HighTech}

MEV II looked at technological improvements (e.g. on process efficiency) and the upscaling of technologies, which are expected to reduce production costs for energy and chemicals. However, this will depend on various factors, such as R\&D efforts or stimulating policies, and poses high uncertainties regarding different development pathways. To capture different possible pathways, we incorporated two extreme scenarios: high technology development (HighTech) and low technology development (LowTech). For each technology we incorporated incremental annual improvement rates in process efficiency. Furthermore, not all technologies are available at the base year, but are expected to emerge in coming periods. Therefore, based on literature and expert judgements we defined the year in which each technology is expected to emerge on a specific scale. For the subsequent periods, we assumed scale increase to capacities permitted by each technology.

The LowTech scenario variants took into account technologies that are available today and moderate scale-up to already installed or announced capacities. The rate of incremental improvements in process yields and autonomous efficiency improvements is conservative.

The HighTech scenario variants assume the implementation of both more technologies and higher scale technologies. The rate of incremental improvements in process yields and autonomous efficiency improvements is more optimistic. The aim of these scenarios was to describe two extreme situations to obtain insights into the significance of stimulating biomass conversion technologies. Production costs in the start year $t_{0}$ of a technology and assumptions related to their development in year $t_{0+n}$ were made exogenously and implemented into the model as cost data and efficiencies (for year $t_{0}$ ) and reduced cost data and improved efficiencies (for years $t_{0+n}$ ). For technologies that are mature (e.g. the esterification of vegetable oils or downstream technologies) and those for which information on future performance is not available, the cost-efficiency data remain constant throughout the modelling period. Increases in capital costs due to process or energy efficiency improvements were ignored. For technologies that were included in MARKAL-NL-UU prior to the present study, costefficiency developments are as in Van Vliet (2011) and Van den Broek et al. (2011).

The start years of fuel production technologies in the HighTech scenarios were based on van Vliet et al. (2011) by delaying their initial estimates by 5 years. In the LowTech scenarios, the start years of technologies are delayed by a further 5 years. Furthermore, gasification technologies were excluded from the technology portfolio of LowTech scenarios. Note that there is no differentiation between LowTech and HighTech scenarios in terms of electricity and heat generation technologies. The production efficiencies and costs in MARKAL-NL-UU were also used in MAGNET, but at a higher level of aggregation (see further Section 3.4).

\subsubsection{General non-scenario-specific assumptions}

GDP and population growth. The calculation of primary energy consumption in the Netherlands in the year 2030 in MAGNET was based on exogenous population and GDP growth patterns. The assumed GDP and population growth were based on the Shared Socioeconomic Pathway 2 (SSP2) scenario of the IPCC (O'Neill, Kriegler et al., 2015). The SSP scenarios define five possible paths that human societies could follow over the next century. The pathways are part of a cooperative research framework that is expected to improve the interdisciplinary analysis and assessment of climate change, its impacts, and the options societies have for mitigation and adaptation (Arnell, Kram et al., 2011). The SSP2 is sometimes referred to as the Middle of the Road (or Dynamics as Usual, or Current Trends Continue, or Continuation, or Muddling Through) scenario (Arnell, Kram et al., 2011; Kram, 2012). It is based on moderate GDP and population growth and is therefore considered a suitable baseline. Technically, GDP will be exogenous only in a pre-simulation to determine the difficult to 
measure sectoral technical change. In the four MEV II scenarios, this was reversed and a part of technological change became exogenous and GDP became endogenous (see Meijl et al., 2016). The latter is key, as GDP was an important objective indicator in the MEV II study.

Fossil energy use and prices. The development of the price of fossil energy (oil, coal and gas) was exogenously determined in MAGNET and MARKAL-NL-UU. The prices are based on the New Policies Scenario of the World Energy Outlook 2014 (WEO) of the International Energy Agency (IEA)

(OECD/IEA, 2015). The New Policies Scenario analyses the evolution of energy markets based on the continuation of existing policies and measures as well as the implementation of policies that have been announced by governments but are yet to be given effect. The New Policies Scenario is consistent with the SSP2 storyline and the WEO 2014 projections are in line with the assumptions in the ECN/PBL study on the 'Energie akkoord'. This agreement involves an increase in the proportion of renewable energy from the current $4 \%$ to $14 \%$ in 2020; in a second stage, the proportion has to increase to $16 \%$ in 2023. Energy saving is another key element of current policies and also in the Dutch Energy Agreement. These factors were taken into account when calculating the final energy demand in the Netherlands. The timeframe of the Dutch Energy Agreement is 2020/2023. Projections of biomass prices are exogenous in MARKAL-NL-UU and endogenous in MAGNET. Table 14 presents the cost prices of fossil fuels and refinery outputs used in the four scenarios. ${ }^{7}$

\section{Table 14}

Cost prices of fossil fuels and refinery outputs used in MARKAL-NL-UU (€ 2010)

\begin{tabular}{|c|c|c|c|c|c|c|c|}
\hline Product & Cost Price & 2010 & 2015 & 2020 & 2025 & 2030 & Reference \\
\hline Crude oil & $€ / G J(\$ / b b l)$ & $10.19(78)$ & $11.97(95)$ & $13.75(112)$ & $14.42(118)$ & $15.1(123)$ & (OECD/IEA, 2015) \\
\hline Coal & $€ / G]$ & 3.28 & 3.22 & 3.15 & 3.25 & 3.36 & (OECD/IEA, 2015) \\
\hline Naphtha & $€ / G]$ & 11.21 & 13.17 & 15.12 & 15.86 & 16.61 & Estimate $^{a}$ \\
\hline Propylene (FCC) & $€ / t$ & 605 & 711 & 817 & 857 & 897 & Estimate $^{\mathrm{b}}$ \\
\hline Ethylbenzene & $€ / t$ & 1,144 & 1,144 & 1,144 & 1,144 & 1,144 & ICIS (2008) \\
\hline Waste (fossil) & $€ / G]$ & $1 \mathrm{E}-04$ & $1 \mathrm{E}-04$ & $1 \mathrm{E}-04$ & $1 \mathrm{E}-04$ & $1 \mathrm{E}-04$ & MARKAL-NL-UUC \\
\hline Uranium oxide & $€ / G]$ & 1.93 & 2.05 & 2.17 & 2.31 & 2.45 & MARKAL-NL-UU \\
\hline
\end{tabular}

a Asche et al. (2003) mention that changes in oil prices are only partly reflected in naphtha price as opposed to other fuel grade refinery products. This is also inferred by the large variation in naphtha refining margins, which is $1-20 \%$ compared to crude oil price (Argus Media, 2012). In the present study, we assumed a price margin for oil refining to naphtha of approximately $\$ 85 /$ tonne, which is equivalent to $10 \%$ of the price difference between oil and naphtha. Note that McKinsey (2012) remarks that applying a constant crack spread of oil-to-naphtha might not be appropriate for estimating future prices.

b As with table footnote (a), for refinery chemicals we assumed a price margin of $20 \%$ compared to the oil price.

c Included in MARKAL-NL-UU database based on Van den Broek et al. (2011) and Van Vliet et al. (2011).

\section{Price of $\mathrm{CO}_{2}$}

The price of $\mathrm{CO}_{2}$ in the $\mathrm{EU}$ in the New Policies scenario is $€ 26 /$ tonne $\mathrm{CO}_{2}$ or $\$ 35 /$ tonne in 2030. Table 15 indicates that the $\mathrm{CO}_{2}$ price is very dependent on the policy scenario as, for example, in the stringent 450 climate change scenario a $\mathrm{CO}_{2}$ price of $€ 71 /$ tonne $\mathrm{CO}_{2}$ is assumed for 2030 . Sensitivity analyses with regard to different $\mathrm{CO}_{2}$ prices is assumed.

\section{Table 15}

$\mathrm{CO}_{2}$ price ( $€$ 2010/tonne $\mathrm{CO}_{2}$ ) for Europe (IEA/OECD, 2014)

\begin{tabular}{llccc} 
Scenario IEA World Energy Outlook & Scenario MEV-II & 2015 & 2020 & 2030 \\
New Policies Scenario & Reference & 10.3 & 15.5 & 26.1 \\
\hline Current Policies Scenario & & 9.6 & 14.1 & 21.2 \\
\hline 450 Scenario & & 10.3 & 15.5 & 70.6 \\
\hline
\end{tabular}

7 In the sensitivity analysis, we varied fossil fuel prices (crude oil, coal, natural gas and refinery outputs) by $50 \%$. 


\subsection{Bottom-up MARKAL-NL-UU modelling}

Scenarios in the bottom-up modelling follow the paradigms described above.

\subsubsection{Methodological structure}

The techno-economic bottom-up model of the energy system of the Netherlands MARKAL-NL-UU builds on the Western European MARKAL model developed by ECN (Smekens 2005). The model has been extended with large-scale conversion technologies relevant for electricity and heat generation and $\mathrm{CO}_{2}$ mitigation options including $\mathrm{CO}_{2}$ capture and storage (CCS) and biomass with CCS (bio-CCS), renewable energy carriers such as wind and PV (van den Broek et al., 2008; van den Broek et al., 2011) and renewable energy, electricity and CCS in transport sectors (van Vliet et al. 2011). The model has also been used in combination with the CGE model World-Scan to assess an international $\mathrm{CO}_{2}$ trading system using a soft-link approach (van den Broek et al., 2011).

Figure 19 depicts the MARKAL-NL-UU modelling framework. MARKAL-NL-UU is a bottom-up, technology-rich and explicit model that uses linear optimization techniques to calculate an intertemporal partial equilibrium on energy and non-energy use markets and generate a least cost path for the total system to deliver demand services (Loulou et al., 2004). Supply- and demand-side conversion technologies are represented by detailed cost structures and process efficiencies. They are deployed in 5-year intervals within scenario constraints such as feedstock supply at a specific cost price, maximum total capacity of a specific technology or minimum production of a specific fuel (e.g. biofuels). The model estimates the minimum present value for the total system as optimal solution, which is a combination of different technologies that deliver demand for user-defined services, namely electricity $(\mathrm{PJ})$ and heat $\left(\mathrm{PJ}_{\mathrm{th}}\right)$, transport kilometres, and demand for materials $(\mathrm{mt})$ and aviation fuels (PJ). Therefore MARKAL-NL-UU outputs are the least cost solutions of an integrated assessment of the total system.

For this study, the MARKAL-NL-UU model was extended with non-energy use sectors, in particular petrochemical and bio-based chemicals. Furthermore, bioenergy technologies (electricity, heat, transport fuels) were also updated. Finally, demand for aviation fuels and related bio-jet production technologies were also included ${ }^{8}$. The extended model enabled an integrated assessment of bioenergy and emerging sectors of the bio-based economy taking into account alternative options of renewable energy as well as possible limitations on the cost-supply potentials of biomass. A detailed description of the technologies in the updated MARKAL-NL-UU is provided in Tsiropoulos et al. (forthcoming). In the appendix we provide flowcharts of the chemical industry module in MARKAL-NL-UU (see Appendix 2).

\footnotetext{
8 In MEV II, aviation sector and related bio-jet production technologies were assessed as an additional scenario and only applied to the bottom-up modeling.
} 


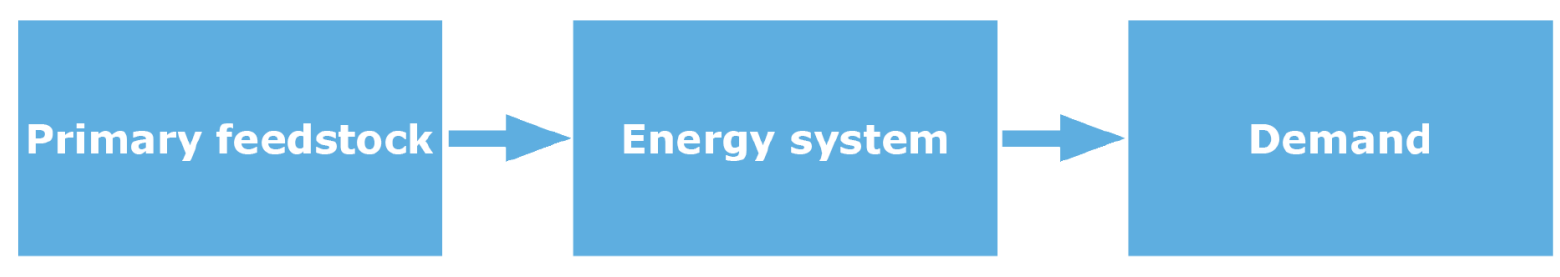

- Coal

- Gas

- Oil

- Nuclear

- Biomass

- Wind

- Solar

- Hydro

\section{Constraints}

e.g. Limits on biomass supply
- Electricity/Heat

- Transport fuels (road, aviation)

- Chemical industry

- Other energy-intensive industry

- Option to couple technologies with CCS

e.g. National policy on tech deployment
- $P J_{\mathrm{el}}$ (electricity)

- $\mathrm{PH}_{\text {th }}$ (heat)

- Vehicle km (road transport)

- PJ (aviation)

- mt (chemicals)

e.g., RE share (EU RED)

Figure 19 MARKAL-NL-UU modelling framework

\subsubsection{Input data}

The key input data of MARKAL-NL-UU are grouped in the following four categories; the data and methods applied to generate these data are described as well. All cost prices are expressed in 2010 euros and energy corresponds to the fuels' low heating value, unless specified otherwise.

\section{Feedstock cost prices and biomass supply potentials}

Cost-supply curves for feedstock categories in MARKAL-NL-UU were estimated based on the following approach. First, transport costs of EU supply were determined based on wood chip logistic costs from NUTS2 regions to Rotterdam based on Hoefnagels et al. (2014a, 2014b). These costs were added to the roadside costs of biomass feedstocks, which were derived from the Biomass Policies project (Elbersen, pers. comm., 2015) and were assumed constant throughout the modelling period. The national cost-supply potential from the NUTS2 level was estimated by aggregating the biomass supply potential of each country's NUTS2 regions and biomass cost of supply to the Netherlands is their weighted average. Biomass supply potentials from the EU-28 (excluding the Netherlands) were aggregated based on weighted average of NUTS2 regions for four geographical regions (North, South, East and West Europe, according to the classification of $\mathrm{UN}^{9}{ }^{9}$ see Figure 21 ).

From the total EU-28 supply, we allocated a specific share available to the Netherlands based on the share of the Dutch Total Primary Energy Supply over the European, according to IEA World Energy Outlook 2014 New Policies Scenario. For 2010-2030, this was estimated to be 4.7-5\%. Note that sugar/starch supply costs are assumed to be the same with global sugar supply costs based on OECD/FAO 2014, as after the abolition of the sugar quota in the EU prices are expected to converge.

Figure 20 presents biomass availability per feedstock. Availability refers to the net potential; it thus excludes traditional competing uses of biomass (e.g. food, feed). For more details on feedstock categories and related conversion technologies, see Appendix 2. Domestic and regional (i.e. EU-28, excluding the Netherlands) feedstock availability for energy and non-energy purposes were estimated, as were the associated logistics costs to bring the biomass to the port of Rotterdam (Appendix 2). For the EU-28 (excluding the Netherlands), global sugar prices were assumed based on the premise that

9 http://unstats.un.org/unsd/methods/m49/m49regin.htm\#europe 
beyond 2017 the abolition of the EU sugar quota, European prices will reach equilibrium with global prices.

In addition to domestic and European biomass supply, global scenarios assume a supply potential from global markets namely for ethanol (first- and second-generation), biodiesel, vegetable oil, sugar and wood pellets. Imported wood pellets and domestic production is limited to $400 \mathrm{PJ}_{\text {prim. Imported }}$

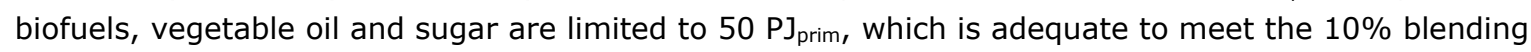
target in 2020. Cost prices of globally traded commodities (which were used only in the open trade scenarios) are shown in Table 16.

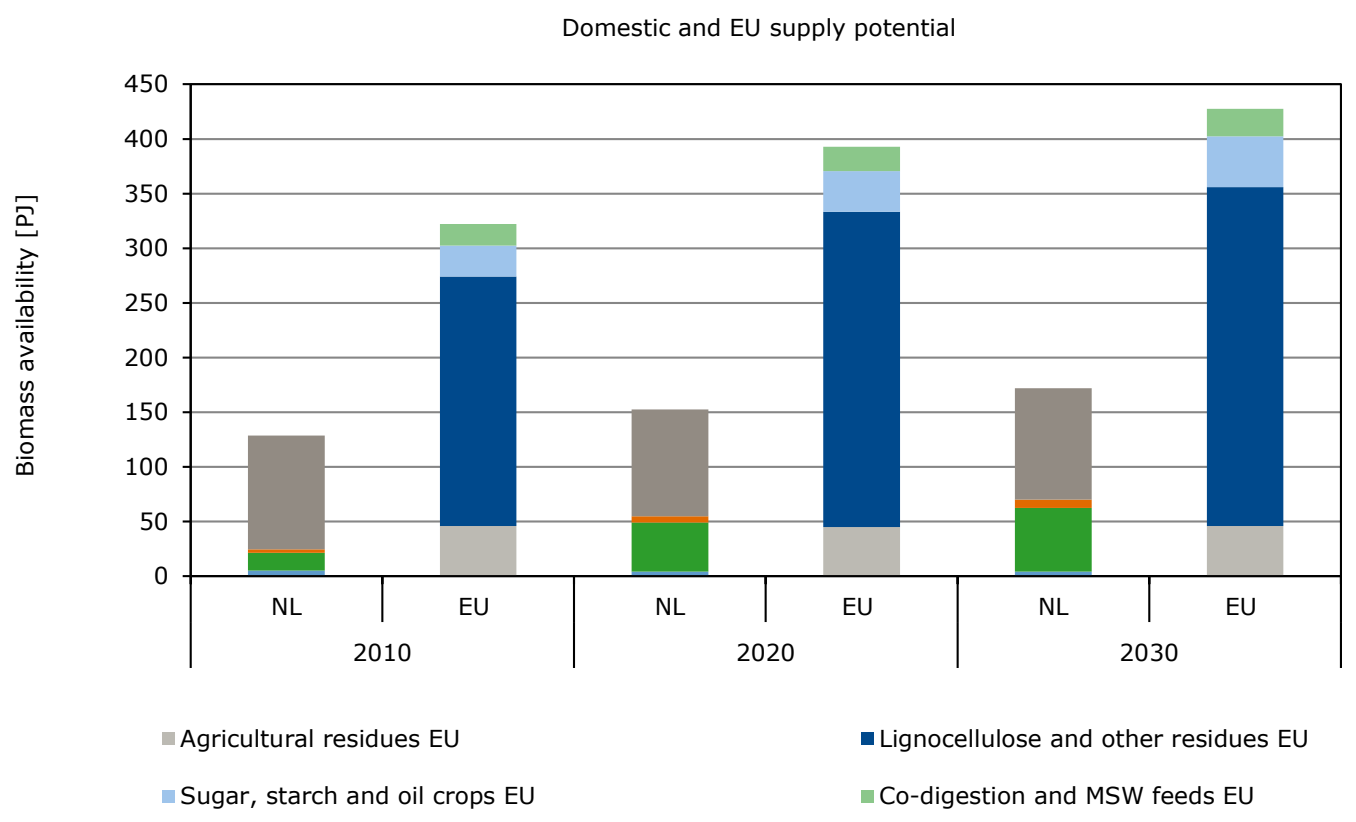

Figure 20 Biomass availability for energy and non-energy use in the Netherlands and the EU-28 (excluding the Netherlands) in 2010-2030

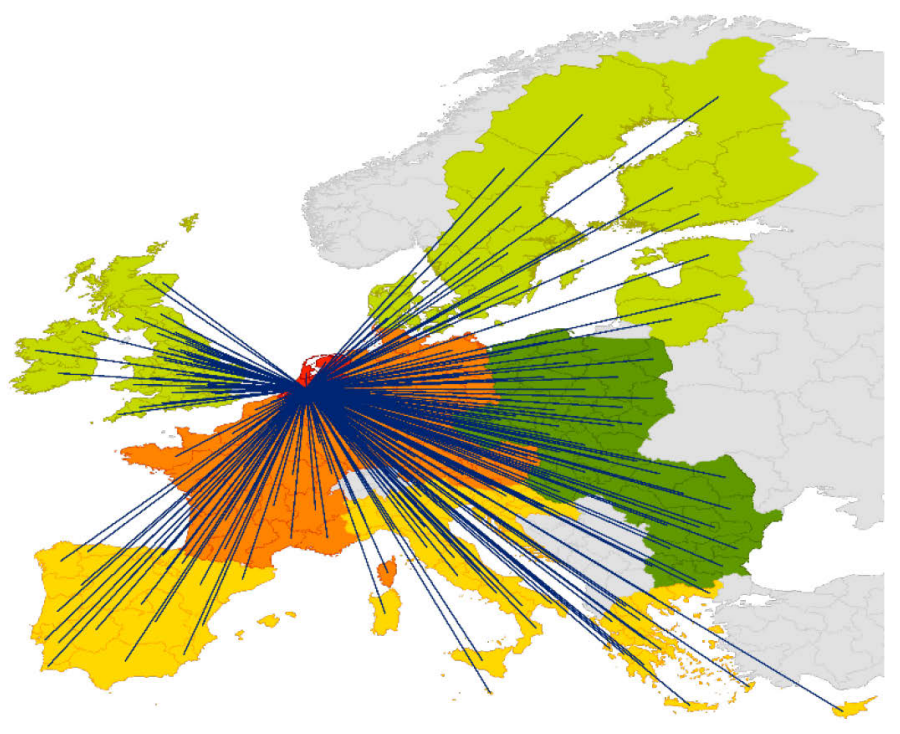

Figure 21 Lines representing cost-supply of feedstocks calculated that are aggregated to the coloured regions based on weighted average cost-supply and incorporated in MARKAL-NL-UU 
Note that we accounted for $\mathrm{CO}_{2}$ emissions using the same methodology (i.e. weighted average of NUTS2 regions to four geographic regions). Domestic emissions from domestically produced biomass contribute to the national $\mathrm{CO}_{2}$ emissions; regional and global emissions are addressed separately and do not affect, for example, the $\mathrm{CO}_{2}$ cap scenario (these are referred to as indirect $\mathrm{CO}_{2}$ emissions).. For domestic and regional biomass production we used emission factors from the JRC analysis set in COM (2010) 11 and SWD (2014) 259. Emission factors used are presented in Appendix 2.

\section{Table 16}

Cost prices of global commodities used in MARKAL-NL-UU

\begin{tabular}{|c|c|c|c|c|c|c|c|}
\hline Product & Cost Price & 2010 & 2015 & 2020 & 2025 & 2030 & Reference \\
\hline Vegetable oil ${ }^{\mathrm{a}}$ & $€ / t$ & 757.8 & 706.0 & 650.2 & 592.9 & 592.9 & (OECD/FAO, 2014) \\
\hline Ethanol (2G) - GlobHighTech & $€ / G]$ & 32.2 & 29.3 & 16.8 & 15.7 & 15.0 & (Jonker et al., 2015) \\
\hline Ethanol (1G) - GlobLowTech & $€ / G]$ & 24.7 & 22.5 & 20.5 & 19.5 & 18.7 & (Jonker et al., 2015) \\
\hline Wood pellets & $€ / G]$ & 7.00 & 7.22 & 7.45 & 7.69 & 7.94 & MARKAL-NL-UU \\
\hline
\end{tabular}

a For imported biodiesel a constant price of $€ 22.5 / \mathrm{G}$ is assumed based on van Vliet et al. (2011).

b Glycerine was not incorporated as a feedstock for downstream conversion; however, credits were assigned to biodiesel production based on the cost prices provided in the table and are applicable across all scenarios.

\section{Cost structures of technologies}

Cost structures of technologies include investment costs, fixed and operation and maintenance costs, technical performance data (process efficiencies, utilities, emissions), as well as their development over the time period under the MEV II study. MARKAL-NL-UU includes a rich database of technologies for the electricity and road transport sector (fuel conversion technologies and vehicles), and the option for CCS (Van den Broek et al., 2011; Van Vliet et al., 2011). Cost structures of these conversion technologies are presented in Appendix 2. Cost data for vehicles and CCS are available on request.

In addition to these technologies, we implemented detailed technology characterization for fossil and bio-based chemical processes (including downstream processing to final products), lignocellulosic sugar and ethanol production, anaerobic digestion, upgrading to SNG and co-generation of heat and electricity, industrial biomass boilers and pyrolysis petrol (a total of $50+$ technologies). The cost structures of these technologies were derived using the following method:

- Capital investment costs are the aggregate of inside battery limit (ISBL; e.g. key process components), outside battery limits (OSBL; e.g. utilities, control systems, buildings, storage) and contingency. Data were obtained from literature and company announcements. For technologies with only ISBL costs, its OSBL costs are assumed to be $35 \%$ of ISBL, and contingency as $25 \%$ of ISBL and OSBL costs. To estimate capital investment costs of technologies at different scales, a 0.7 scaling factor is applied in the formula:

$$
\frac{\text { Cost }_{\text {base }}}{\text { Cost }_{\text {scaled }}}=\left(\frac{\text { Capacity }_{\text {base }}}{\text { Capacity }_{\text {scaled }}}\right)^{\text {Scaling factor }} \text { Equation } 3.1
$$

- Location factors were used to estimate investment costs referring to non-European regions (Appendix 2).

- Fixed costs were harmonized across conversion technologies based on factors presented in Hermann and Patel (2007) (see Appendix 2). If the data source presents a breakdown of fixed cost components, these were used instead. An annual full time salary of $€ 56,210 /$ year was used to estimate labour costs. ${ }^{10}$ If data sources did not provide labour (costs) in full time equivalents, these

$10 \quad$ Based on wage of $€ 28.69 / \mathrm{h}$ and $2,080 \mathrm{~h} /$ year for industry in the Netherlands in 2005 (Eurostat, 2014). Converted to 2010 wages using labour cost indices for the Netherlands (Eurostat, 2014). 
were set at $5 \%$ of the variable costs. Labour costs were scaled based on Equation 3.1 and a 0.2 scaling factor.

- For technologies that require external energy input (electricity, heat), the model takes into account the additional demands and supplies by conversion technologies deployed based on the system's least cost pathways. Variable costs of technologies that are self-dependent on energy are indirectly accounted for as additional capital investments (e.g. CHP, boiler). Other variable costs taken into account are cellulose in second-generation sugar and ethanol technologies, catalyst costs in pyrolysis technologies, and acetic acid costs in PTA production.

Production costs are related to the $\mathrm{n}^{\text {th }}$ plant, thereby excluding potentially higher costs of the first installed unit due to operation at low utilization rate. The cost components described above for each technology can be provided upon request.

Appendix 2 shows the different improvement rates that were assumed per technology in each scenario. Figure 22 presents the start year, the technologies and their capacities assumed in each scenario for the chemical conversion technologies. Further details on technology development are provided in Appendix 2.

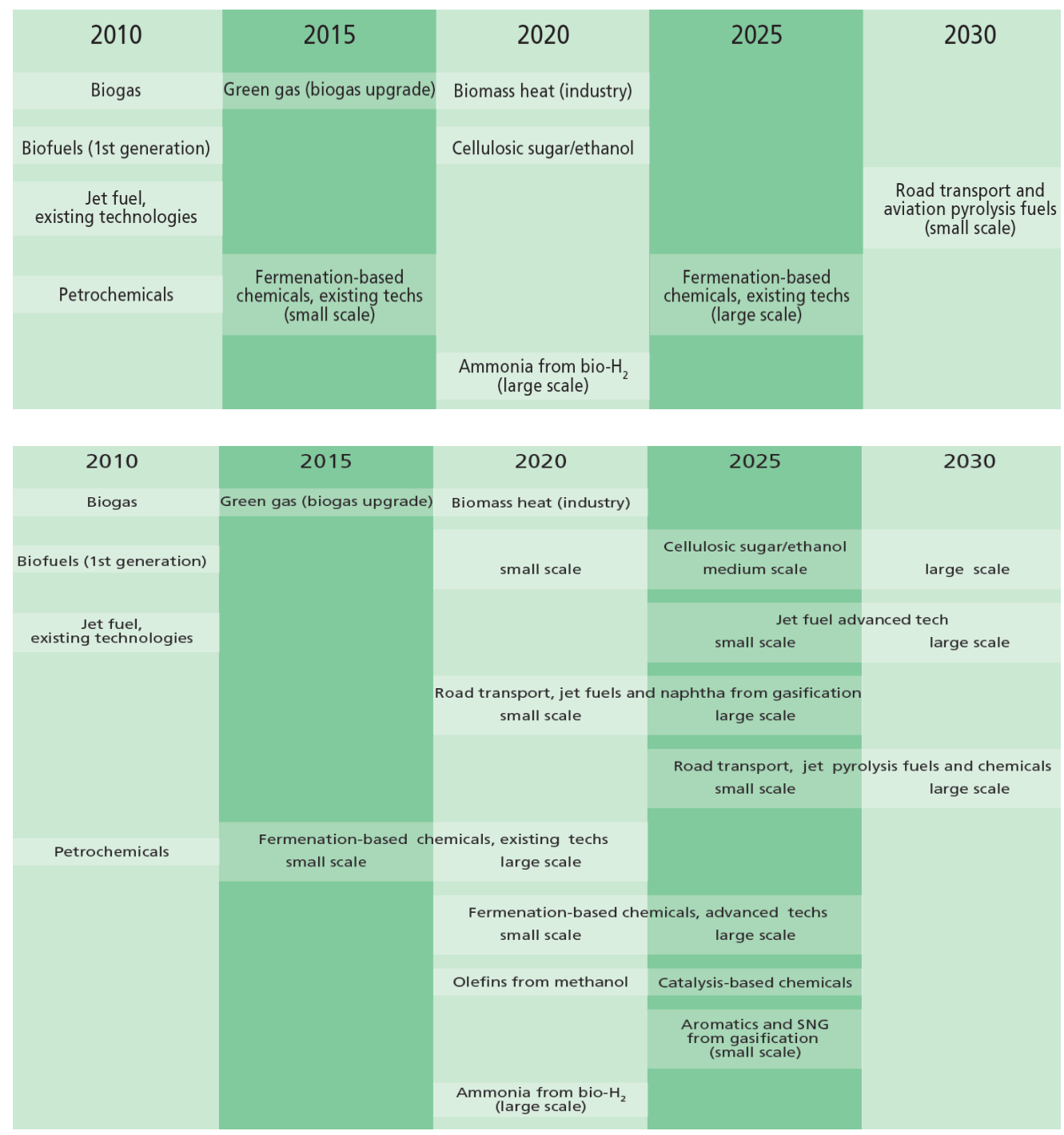

Figure 22 Start years and scales of technologies incorporated in MARKAL-NL-UU for the low (upper figure) and high (lower figure) technology development scenario variants 


\section{Demand projections for energy and chemicals}

\section{Energy}

The final energy demand for electricity and heat is based on the latest projections for established policies by the Energy Research Center (ECN) in the Netherlands (Table 17; ECN, 2015). The demand for transport vehicle kilometers follows Van Vliet et al. (2011).

\section{Table 17}

Final electricity and heat demand in MARKAL-NL-UU

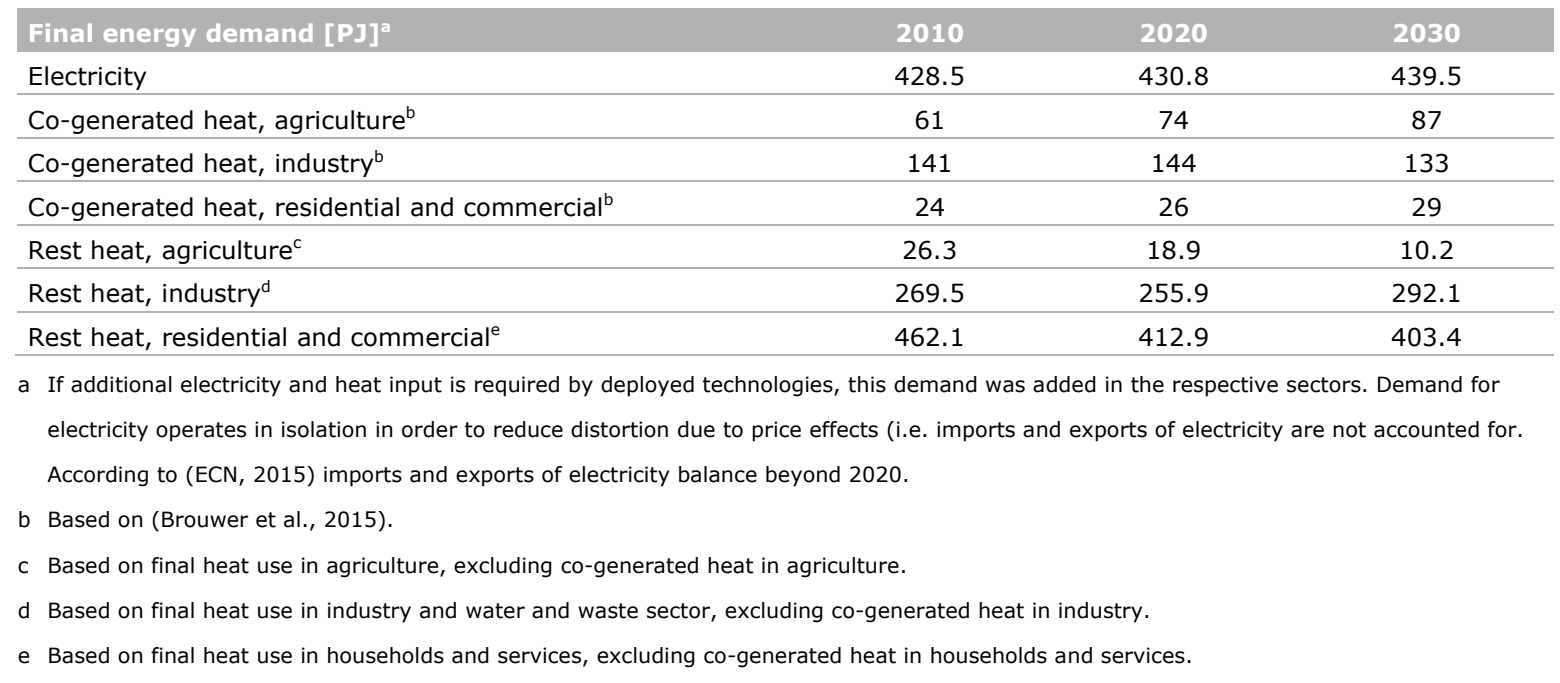

\section{Chemicals}

The level of capacity investments either as expansion of the existing conventional petrochemical industry or deployment of biomass conversion technologies depends on production of chemicals in the Netherlands to 2030 to meet domestic and export demand. We define demand as the production volume of chemicals in the Netherlands as opposed to domestic consumption due to complex trade flows of chemical commodities (e.g. re-exports, conversions to different commodities). This is in contrast to the final demand for electricity, heat and road transport fuels, which in this model is based on domestic consumption (i.e. imports-exports of electricity and fuels are ignored). To determine the production volume of chemicals we used publically available data on production capacities in 20062011 based on Chemweek (2000-2009), Neelis et al. (2003, 2007a, 2007b), ICIS (2006), Lako (2009) and OGJ (2012) (Appendix 2). These were extrapolated to 2010, and up to 2030 based on the high growth rates in IEA (2009) (Appendix 2). A sensitivity on demand projection is also assessed and presented in Section 5.1.5. To estimate the production volume, capacity utilization rates of $85 \%$ were assumed (Neelis et al., 2005). The volume of basic chemicals not used for the production of intermediate or final products is defined as residual demand for each basic chemical (Appendix 2). This was determined based on the total volume of basic chemicals produced in the Netherlands minus the demand for production of intermediate and final products according to capacities and process yields and the residual capacities. (Appendix 2).

\section{Aviation}

Demand for the production of fossil jet fuels is based on an average of scenario projection studies according to the Climate-KIC project RENJET, see Table 18.

\section{Table 18}

Demand for fossil jet fuels

\begin{tabular}{lccccc}
{$[\mathrm{PJ}]$} & 2010 & 2015 & 2020 & 2025 & 2030 \\
NL Demand Jet & 145 & 157 & 169 & 182 & 195 \\
\hline
\end{tabular}




\section{Policy constraints}

Under the EU RED, each member state has an obligation to meet country-specific targets to achieve the Union's target of 20\% renewable energy share in the final energy demand by 2020 (EC, 2009). For the Netherlands, this corresponds to a minimum of $14 \%$ renewable energy in the country's final energy demand (electricity, heat and transport fuels). In addition, 10\% of final energy demand in transport must be of renewable origin (biofuels, renewable electricity). Biofuels from wastes, residues, non-food cellulosic material and lingo-cellulosic material contribute twice and renewable electricity contributes 2.5 times to the blending target. Note that renewable transport fuels also contribute to the renewable energy target. In addition, the Dutch Energy Agreement (SER, 2013) outlines specific goals regarding the maximum use of biomass for co-firing in coal power plants, and the deployment of onshore and offshore wind and a renewable energy share in final energy demand beyond 2020 (Table 19). In addition, all reference scenarios include $\mathrm{CO}_{2}$ tax levels in all sectors based on the International Energy Agency's (IEA) New Policies scenario. This study captures these policies in all scenarios.

\section{Table 19}

Targets affecting energy supply in the Netherlands based on the Dutch energy agreement as incorporated in MARKAL-NL-UU (SER, 2013) and $\mathrm{CO}_{2}$ tax levels

\begin{tabular}{lc} 
Measure & Quantitative target \\
\hline Share of renewable energy in final energy $(2023)^{\mathrm{a}}$ & $16 \%$ \\
\hline Additional capacity of offshore wind power (2015) & $0.13 \mathrm{GW}$ \\
\hline Additional capacity of offshore wind power (2016-2020) & $1.65 \mathrm{GW}$ \\
\hline Total capacity of onshore wind power (2020) & $6 \mathrm{GW}$ \\
\hline Maximum final energy from biomass for co-firing (2020) & $25 \mathrm{PJ}$ \\
\hline Coal-power plants decommissioning (2016) & $1.65 \mathrm{GW}$ \\
\hline Coal-power plants decommissioning $(2017)^{\mathrm{b}}$ & $1.4 \mathrm{GW}$ \\
\hline $\mathrm{CO}_{2}$ tax $2020^{\mathrm{c}}$ & $€ 15.5 / \mathrm{t}$ \\
\hline $\mathrm{CO}_{2}$ tax 2030 & $€ 26.1 / \mathrm{t}$ \\
\hline a In MARKAL-NL-UU implemented as a binding target for 2025. & \\
b In MARKAL-NL-UU implemented in 2020. & \\
c Based on IEA WEO (2014) New Policies Scenario. & \\
\hline
\end{tabular}

Note that market constraints for biomass conversion technologies to fuels (to slow down rapid scaleup) were also assumed. No single second-generation technology type can supply more than $5 \%$ of fuel demand in 2020 or more than $10 \%$ in 2030 . Also reference scenarios exclude forced treatment of manure, exclude the aviation sector and continue the blending target beyond 2020 (frozen target from 2020 to 2030), and $\mathrm{CO}_{2}$ emission tax is applied to all sectors. These were selected as reference choices to harmonize scenario assumptions between MAGNET and MARKAL. For aviation scenarios, a $3.8 \%$ blending target was set for biojet fuel in the aviation fuel pool based on the EU's ambition for 2020 described in the European Advanced Biofuels Flightpath.

\subsection{Top-down MAGNET modelling}

The MEV I study modelled the biomass and bioenergy conversion technologies and fossil-based conversion technologies at a relatively high aggregation level in MAGNET. Furthermore, bio-based shares for fuels, electricity and chemicals were exogenously determined (based on a bottom-up approach) in the MEV I study. Endogenous developments within the macroeconomic model require: (i) bio-based fuels and their fossil substitutes have to be explicitly modelled to allow for substitution effects, (ii) renewable substitutes like solar and wind energy should be explicitly modelled, (iii) heat has to be included as it is an important user of biomass, (iv) RED policies are key and should be modelled explicitly, and ( $v$ ) greenhouse gas emissions have to be modelled explicitly as many policies are GHG related (e.g. $\mathrm{CO}_{2}$ taxes). Renewable energy sources (e.g. wind, sun) and the bioenergy and biochemical sectors were not treated as separate sectors in MAGNET in MEV I. To close these gaps and 
make bioeconomy developments endogenously, the MEV II study expanded the Global Trade Analysis Project (GTAP) database that is used in MAGNET. More specifically, MAGNET was expanded with information on:

- Supply of biomass (residues, plantations, pellets).

- Second-generation biofuels (thermal and biochemical pathways)

- Renewable electricity generation technologies (e.g. biomass, wind and solar, hydro).

- Fossil electricity generation technologies (e.g. coal, gas, nuclear).

- Bio-based chemicals (a few main routes (bulk bio-based polymers): direct sugars to chemicals, ethanol to chemicals, thermochemical-based feedstocks).

Furthermore, to enable energy policies and reflect better the Dutch economic situation the database was extended or updated with:

- Greenhouse gas emissions per technology/sector.

- Greenhouse gas policies ( $\mathrm{CO}_{2}$ taxes, $\mathrm{CO}_{2}$ targets).

- Renewable energy shares.

- Current and future costs and conversion efficiencies of fossil and bio-based energy and chemical chains.

- Production volumes in the reference year (based on Dutch IO table, Verhoog 2014).

- Seize of (bio-based) production sectors (based on Dutch IO Table, Verhoog 2014)

In Section 3.4.1 we discuss the methodology of MAGNET and in Section 3.4.2 we describe the new bio-based and fossil-based sectors added to the global MAGNET model. Sections 3.4.3 describes the model aggregation and implementation of the scenarios in MAGNET.

\subsubsection{Methodological structure}

The Modular Applied GeNeral Equilibrium Tool (MAGNET) is a recursive dynamic, multi-regional, multicommodity CGE model, covering the entire global economy (Woltjer et al., 2013). It is built upon the GTAP model (Hertel, 1997) and is the successor to the LEITAP model, which was used in the MEV I study and in many other policy analyses (see e.g. Banse et al., 2008; van Meijl et al., 2006; Nowicki et al., 2009, Woltjer, 2011). MAGNET is one of the nine global models selected in the OECD\AgMIP model inter-comparison project on the long term future of agriculture (including bioenergy developments; see Nelson et al., 2013; Von Lampe et al., 2014, Lotze-Campen et al., 2014 and Robinson et al., 2014).

Starting point of MAGNET is the GTAP model (Hertel, 1997). The core of GTAP is an input-output model that links industries in value added chains from primary goods, over continuously higher stages of intermediate processing, to the final assembly of goods and services for consumption. Primary production factors, namely, land, labour and capital, are employed within each economic region, and hence returns to land and capital are endogenously determined at equilibrium, that is, the aggregate supply of each factor equals its demand. GTAP assumes perfect competition, namely producers are price takers whereas in order to produce output they choose the cheapest combination of imperfectly substitutable labour, capital, land, natural resources and intermediates. Input and output prices are endogenously determined by the markets so as to achieve supply and demand equilibrium. Factor markets are competitive between sectors but not between regions. Households are assumed to distribute income across savings and government and private consumption expenditures according to fixed budget shares. Consumption expenditures are allocated across commodities according to a nonhomothetic CDE (constant differences of elasticity) expenditure function. Land, labour, capital and natural resources (primary production factors) are fully employed in each region and the aggregated supply of each factor equals its demand (equilibrium). Furthermore, GTAP assumes imperfect competition between domestic and imported commodities (Armington assumption).

The MAGNET model, in comparison to GTAP, uses a more general multilevel sector-specific nested CES (constant elasticity of substitution) production function, allowing for substitution between primary production factors (land, labour, capital and natural resources) and intermediate production factors, and for substitution between different intermediate input components (e.g. energy sources and animal feed components). MAGNET includes an improved treatment of agricultural sectors (e.g. various 
imperfectly substitutable types of land, the land use allocation structure, a land supply function, and substitution between various animal feed components; Meijl et al., 2006, Eickhout et al., 2009), agricultural policy (e.g. production quotas and different land-related payments; Nowicki et al., 2009) and biofuel policy (capital-energy substitution, fossil fuels-biofuels substitution; Banse et al., 2008). On the consumption side, a dynamic CDE expenditure function is implemented which allows for changes in income elasticities when purchasing power parity (PPP) corrected real GDP per capita changes. Segmentation and imperfect mobility between agriculture and non-agriculture labour and capital are introduced in the modelling of factors markets.

The core of the MAGNET database is the GTAP database. MAGNET uses a series of additional databases, such as GTAP satellite databases, FAOSTAT (commodity balances, land use, land cover and fertilizer), data on biofuels from the International Energy Agency and land use parameters taken from the IMAGE model. The processing of data is coded to make it easier to update the original source data, to track how data are processed and to maintain flexibility using different GTAP database versions. Possible adjustments of the data that MAGNET can make include disaggregating regions and sectors, rebalancing the social accounting matrix, and adding data on land use, land cover, greenhouse gasses, employment or international capital flows. Having these procedures in place allows the introduction of first-generation biofuels (ethanol and biodiesel), DDGS (by-product from grain-based ethanol production, used as animal feed) and splitting several GTAP sectors to include a sector that only makes crude vegetable oil with oilcake as a by-product, the new bioeconomy sectors studied in this report (see Section 3.4.1), fertilizer sectors, an animal feed sector, and splitting sugar production into plain sugar and molasses. Additional bilateral trade data are taken over from BACI, ${ }^{11}$ whereas data on import tariffs for the new sectors are taken from MacMaps. All data are processed starting from the aggregation level at which they are supplied, and they are aggregated or disaggregated using mappings towards the lowest aggregation level that MAGNET uses. This implies that, for example, tariff data are considered at the HS6 digit level and aggregated (weighted averages) according to the chosen commodity aggregation scheme for a particular study.

\subsubsection{Input data for new sectors}

The GTAP database that is used in MAGNET was expanded with several new sectors, using data from the MARKAL-NL-UU model and several other sources, as explained below. These new sectors cover the supply of biomass and the conversion of biomass to electricity, second-generation biofuels and biobased chemicals. A simplified overview of these new sectors and the linkages between these sectors and with the existing sectors in MAGNET is provided in the figure below (Figure 23). The coloured boxes represent the new sectors introduced in MAGNET. The grey sectors are existing sectors in MAGNET, as described in Woltjer and Kuiper (2014). The arrows show the deliveries between sectors. The fuel sector in the graph below mixes conventional fuels from the petro sector with first- and second-generation biofuels. A chemicals sector (not shown in the figure) mixes bio-based and conventional chemicals.

\footnotetext{
$\overline{11}$ 'Base pour I'Analyse du Commerce International' (CEPII, 2013).
} 


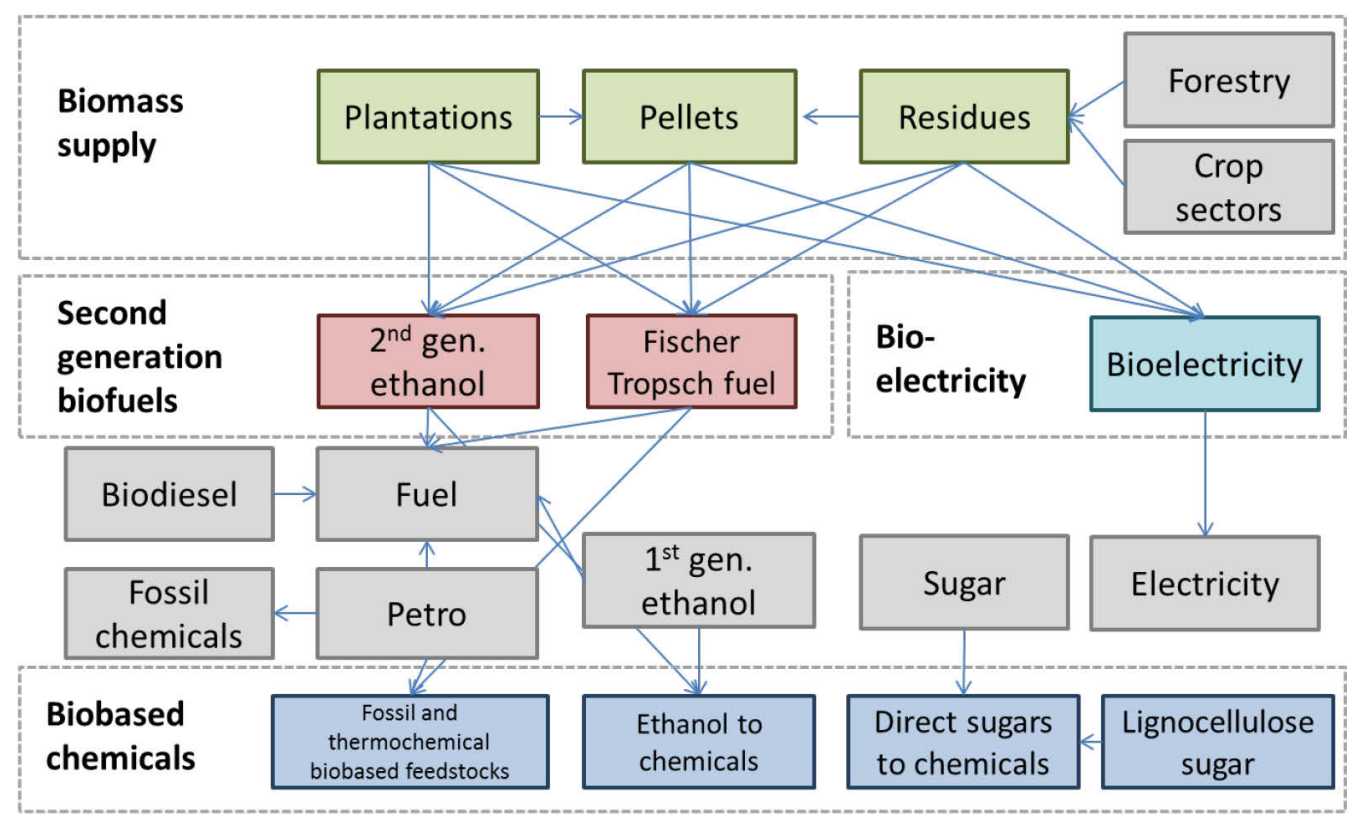

Figure 23 Overview of bio-based sectors and linkages in MAGNET

\section{Biomass supply}

Three new sectors in MAGNET model the supply and trade of biomass:

- Residues

- Plantations

- Pellets.

Pellets are assumed to become an important primary energy carrier for bioenergy and biomaterial production, as they can be easily stored, transported and traded. The pellet sector delivers biomass to various biomass using sectors, such as the bioelectricity sector and the second-generation biofuel sectors. The pellet sector uses raw, untreated biomass from the residues sector and from the plantations sector. The price of biomass in MAGNET was set at $\$ 9.0 / G$ ] in the MAGNET base year (2007), which is the price of pellets considered in MARKAL-NL-UU in the year 2010. Projections of biomass prices in 2030 are endogenous in MAGNET. Data on the trade of pellets were taken from UN COMTRAD database (2015). The plantation sector produces biomass for energy production using dedicated woody or grassy energy crops. Data on the cost structure of plantations are based on Stehfest et al. (2014). The residues sector collects and transports various types of residues:

- Forest harvest residues: residues from forest management and logging that are usually left in the field, and residues from the wood processing industry, such as bark, shavings, sawdust, etc.;

- Agricultural residues: residues from the harvesting and processing of agricultural crops (wheat, other grains, rice, horticulture, oilseeds, other crops).

Processing residues of food and forest biomass processing are added to harvest residues of crop production and forest sector. Data for the MAGNET base year (2007) on conversion efficiencies, costs of capital, operation \& maintenance (O\&M), and other costs are based on the IMAGE model from the Netherlands Environmental Assessment Agency (Daioglou et al., 2015). The sustainable supply potential of (lignocellulose) residues in the Netherlands and the EU-28 in 2007 is based on results from the EC FP 7 Biomass Policies (Elbersen et al., 2015). Data for other regions in the world were taken from the Integrated Assessment of Global Environmental Change (IMAGE) (Daioglou et al., 2015; Stehfest et al., 2014).

\section{Second-generation biofuels}

Two production technologies for second-generation biofuels in MAGNET were considered:

- Second-generation biofuel - thermal pathway fuels: Fischer-Tropsch (FT) fuel production via gasification of lignocellulose biomass and FT synthesis. 
- Second-generation biofuel - biochemical pathway fuels: cellulosic ethanol includes the production of ethanol from lignocellulose biomass.

Data on current and future conversion costs (exc. feedstock costs) and conversion efficiencies were taken from MARKAL-NL-UU (see Section 3.3.2).

\section{Electricity}

The electricity producing sector in MAGNET is split into seven source sectors:

- Electricity biomass

- Electricity coal

- Electricity gas

- Electricity wind and solar

- Electricity nuclear

- Electricity hydro and geothermal

- Electricity distribution and transport.

Data on the production and consumption of electricity in the Netherlands were taken from CBS statistics. For the rest of the world, energy statistics from the International Energy Agency (IEA, 2010) and the Energy Information Administration were used (EIA, 2014). Information about the current and future costs of electricity generation (exc. feedstock costs) were taken from MARKAL-NL-UU

(Section 3.3.2). Fossil energy prices are based on projections of the IEA (2015) (see Section 3.2.3).

\section{Heat}

The use of biomass for the production of heat is not considered as a separate sector in MAGNET, but as a direct substitute for natural gas. The use of biomass for heat in the MAGNET base year (2007) is based on data from MARKAL-NL-UU.

\section{Chemicals}

The chemical sector is split into various conventional, bio-based and mixed conventional/bio-based sectors, as shown in the Table 20. The chemical sector is a very heterogeneous sector and some promising technologies were selected to include in the macroeconomic model. The focus of MEV II was more on large scale bio-based production technologies that are a substitute for fossil-based production and on the impact of technical change. This is less relevant for existing biochemical production systems that were not considered in MEV II, because: 1) there is no fossil alternative for some technologies (e.g. for yeast); 2) bio-based is technically the preferred feedstock/technology; 3 ) HighTech change is probably not very relevant for established technologies; and 4) the high value added of the end-products of existing bio-based sector means that the share of energy in the cost structure is probably limited, and thus so too is the impact of climate change and renewable energy policies. In addition, we had no detailed cost structures of these technologies that we could obtain from the bottom-up analyses, and we therefore included the most important technologies as considered in MARKAL-UU-NL; other existing bio-based technologies were not considered. Based on MARKAL-UU-NL analyses, three attractive and representative pathways were identified:

- Direct sugar to chemicals

- Ethanol to chemicals

- Thermochemical-based feedstocks.

Figure 23 and Table 20 show which technologies were chosen as representative of these three pathways (as in MARKAL-NL-UU, and in reality, we have a much wider range of technologies) for these categories. 
Table 20

Chemical pathways and representative technologies considered in MAGNET

\begin{tabular}{ll} 
Chemical pathways & Representative technologies \\
Direct sugars to chemicals & Polylactic acid (PLA) \\
\hline Ethanol to chemicals & Polyethylene (PE) \\
\hline Thermochemical-based feedstocks & FT naphtha
\end{tabular}

The broad range of chemicals considered in MARKAL-NL-UU is considered in MAGNET by including the most attractive and representative pathways. Polylactic acid is considered, since this is a potentially attractive direct sugars to chemicals (fermentation-based conversion) pathway. Both conventional sugar from sugar beet and sugar cane and sugar from lignocellulose biomass are included as feedstock. The use of ethanol for polyethylene production in MAGNET is a proxy for the use of ethanol as feedstock for the chemical industry. Polyethylene can be made of first- and \or second-generation ethanol. The mixed bio/fossil chemicals sectors include the production of polyethylene from fossil and thermochemical-based feedstock bio-based naphtha.

\subsubsection{Model aggregation and scenario implementation}

MAGNET is calibrated to version 8 of the GTAP database with base year 2007. The database was aggregated into 8 countries or regions and 63 commodities (Table 22) to reflect the modelling of bioeconomy sectors and policies and capture the effects on energy, chemical and agricultural markets. This involved identifying the following sectors separately: biomass feedstocks (e.g. residues, plantations, pellets, wheat, coarse grains, sugar cane and sugar beet, crude vegetable oil), livestock (ruminants and non-ruminants), by-products used as compound feed components (DDGS, oilcakes), first- and second-generation biofuels (ethanol and biodiesel), bio-based (PLA, PE, second-generation FT) and fossil chemicals, fertilizers, and the renewable (wind and solar, biomass, hydro and geothermal) and fossil (crude oil, natural gas and coal) energy sectors. The regional disaggregation separates the Netherlands, a few neighbouring EU countries and the rest of the world from geographical aggregates.

The SSP2 scenario represents business as usual developments in the world economy over the period 2015-2030, based on conventional economic and demographic trends, and under an assumption of no new policy changes. The expected growth in GDP and associated technological progress together with population changes to a large extent determine the future demand for produced commodities and the supply of primary production factors. Labour and capital availability together with technological progress determine the production possibilities. The baseline scenario uses the macroeconomic projections data from the SSP2 scenario of IPCC (Kram, 2012; see Section 3.2.3). The average annual growth rate is assumed to be $3.1 \%$ for world's GDP and a $0.9 \%$ increase in global population, during the 2015-2030 period (see Table 21). However, economic and population developments differ between countries and regions, as Table 21 shows. Conforming to stylized facts of long-term economic growth, capital is assumed to grow at the same rate as GDP and long-term employment growth is assumed to be equal to population growth. The baseline scenario assumes no policy changes and no new policies in the simulation period, and only applies existing policies and those agreed upon for the future, such as the Renewable Energy Directive and the mandatory biofuel targets.

In the calibration stage, regional- and sectoral-specific technological change was calibrated by forcing the model to meet the exogenous GDP targets given the exogenous estimates of factor endowments skilled labour, unskilled labour, capital and natural resources - and population. This level of technological change is translated to the sectoral level using a sector-specific growth ratio of total factor productivity based on Central Planning Bureau (CPB 2003) figures. We used additional information on crop yield improvements to mimic the land embodied technological progress. The technological change, in turn, is exogenous in the baseline scenario and simulation experiments, GDP becomes endogenous and calibrated values for technological changes are used. 
Table 21

Macroeconomic assumptions (\%)

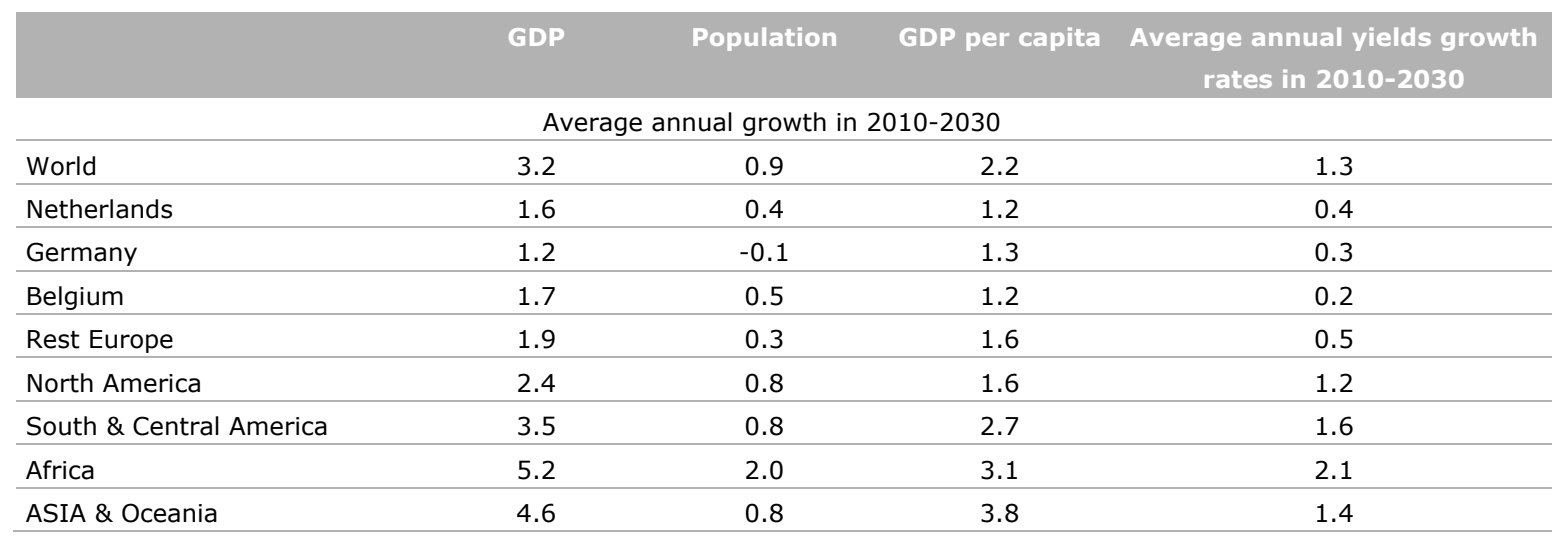

Note. The regional aggregation and their abbreviations are presented in Appendix A.

The exogenous yield improvements are derived from the FAO study 'World agriculture: towards 20152030' (Bruinsma, 2003). Land availability is based on IMAGE 2.4 data (Bouwman et al., 2006).

Table 21 indicates that globally, average agricultural yields will increase by about $1.3 \%$ annually. For the regions South and Central America, Africa and Asia \& Oceania, yield increases are expected to increase faster than world averages, whereas for other regions, the annual growth rates are predicted to be lower than $1.3 \%$.

We assume an exogenous development in the energy savings in accordance with the projections of the energy agreement. World prices of fossil fuels (coal, gas and crude oil) are based on IEA projections. We also include a $\mathrm{CO}_{2}$ tax that accords with IEA projections.

For the four MEV II scenarios, all macro and policy assumptions (i.e. the biofuel mandates and energy directive targets) are the same across all four scenarios. The scenarios differ only on two dimensions: - HighTech versus LowTech: In the HighTech scenarios technological change is higher for all secondgeneration biofuels (ethanol and biodiesel) and bio-based chemicals (PLA, PE, second-generation FT). All these technologies become cost competitive in 2030 given the assumed oil prices.

- Regional versus Global dimension is introduced as no access to second-generation biomass (residues, pellets) and biofuels from non-EU countries. Important to notice that primary feedstocks related to food (e.g. sugar, wheat and maize) are allowed from non-EU to EU countries.

As a counterfactual, a non-bio-based scenario was created. In this scenario, all RED policies are abolished and bioeconomy developments in the transport, chemical and energy sectors are kept at or below the current levels. 


\section{Table 22}

\section{MAGNET data aggregation}

\section{Sectoral disaggregation ( 63 commodities):}

Primary agriculture (11 commodities): pdr (paddy rice); wheat (wht); other grains (grain); oilseeds (oils); raw sugar (sug); vegetables, fruits and nuts (hort); other crops (crops); cattle and sheep (cattle); pigs and poultry (pigpoul); raw milk (milk); crude vegetable oil (cvol);

Food and beverages ( 6 commodities): meat $(\mathrm{cmt})$; meat product (omt) dairy (dairy); sugar processing (sugar); vegetable oils and fats ( $\mathrm{vol})$; other food and beverages (ofd);

Other 'traditional' bio-based activities ( 2 Commodities): fisheries (fish); forestry (frs);

Bio-mass supply (10 commodities): plantations (plan); residue processing (res); pellets (pel); agricultural residues (r_pdr, r_wht, r_grain, r_oils, r_crops, r_hort); forestry residues (r_frs);

Bio-based energy ( 9 commodities): first-generation biodiesel (biod); first-generation bioethanol (biog); bioelectricity (bioe); second-generation thermal technology biofuel (ft_fuel); second-generation biochemical technology biofuel (eth); biofuel feedstock grains (bf_g); biofuel feedstock molasses (bf_m); biofuel feedstock oils (bf_o); biofuel feedstock sugar (bf_s);

Bio-based chemicals (4 commodities): lignocellulose sugar (Isug); polylactic acid (pla); polyethylene (pe); mixed bio/fossil chemicals (f_chem);

Bio-based and non-bio-based animal feeds ( 4 commodities): bioethanol by-product distillers dried grains and solubles (ddgs); biodiesel by-product oilcake (oilcake); animal feed (feed).

Fertilizer ( 3 commodities): fertilizer nutrient nitrogen (fert_N), phosphorous (fert_P), potassium (fert_K).

Fossil fuels (5 commodities): crude oil (c_oil); petroleum (petro); gas (gas); gas distribution (gas_dist); coal (coa); Electricity (6 commodities): electricity from gas (ely_g); electricity from coal (ely_c); electricity from nuclear (ely_n); electricity from wind and solar (ely_w); electricity from hydro and thermal (ely_h); electricity transport (ely); Other sectors (4 commodities): chemicals, rubber and plastics (chem); transport (trans); other industry (OthInd); services (serv).

Regional disaggregation (8 regions):

EU members (4 regions): Netherlands (NLD); Germany (DEU); Belgium (BEL); Rest Europe (REU)

Non-EU regions (4 regions): North America (NA); South and Central America (SCA); Africa (AF); Asia and Oceania (ASIA). 


\section{$4 \quad$ Scenario results for the Netherlands in 2030}

Section 4.1 describes the scenario results for the Netherlands until 2030 of the bottom-up analyses performed by the MARKAL-NL-UU model. Section 4.2 presents the results for the top-down analyses. A comparison between the model results is given in Section 4.3. Section 5 provides a sensitivity analyses with regard to $\mathrm{CO}_{2}$ policies.

\subsection{Bottom-up MARKAL-NL-UU projections}

In this section we present results for the four reference scenarios (RegLowTech, GlobLowTech, RegHighTech, GlobHighTech), which are described in Section 3.2. First, we show the deployment of renewable energy in the Dutch energy system in terms of final energy use (Section 4.4.1). In Sections 4.1.2-4.1.5, we discuss in more detail the four sectors that are included in the bottom-up systems analysis (electricity, heat, transport fuels, chemicals). We then present outcomes for biomass consumption levels in the reference scenarios, types and sourcing of biomass feedstocks and biomass consumption per sector (Section 4.1.5). We conclude this section by presenting results on direct $\mathrm{CO}_{2}$ emissions of the Dutch energy system across the four reference scenarios (Section 4.1.6).

\subsubsection{Final energy use}

Figure 24 shows the delivery of fossil and renewable energy and non-energy expressed as final energy. It also shows the contribution of renewable resources to the overall final energy use as well as the contribution of biomass, by accounting only for energy uses (electricity, fuels, heat) and separately also including non-energy uses (chemicals). ${ }^{12}$

\footnotetext{
${ }^{12}$ Non-energy use of chemicals was determined on the basis of lower heating value of feedstock (naphtha and natural gas), aromatics, ethylbenzene for fossil chemicals, and lower heating value of bio-based chemicals based on product output in each scenario.
} 


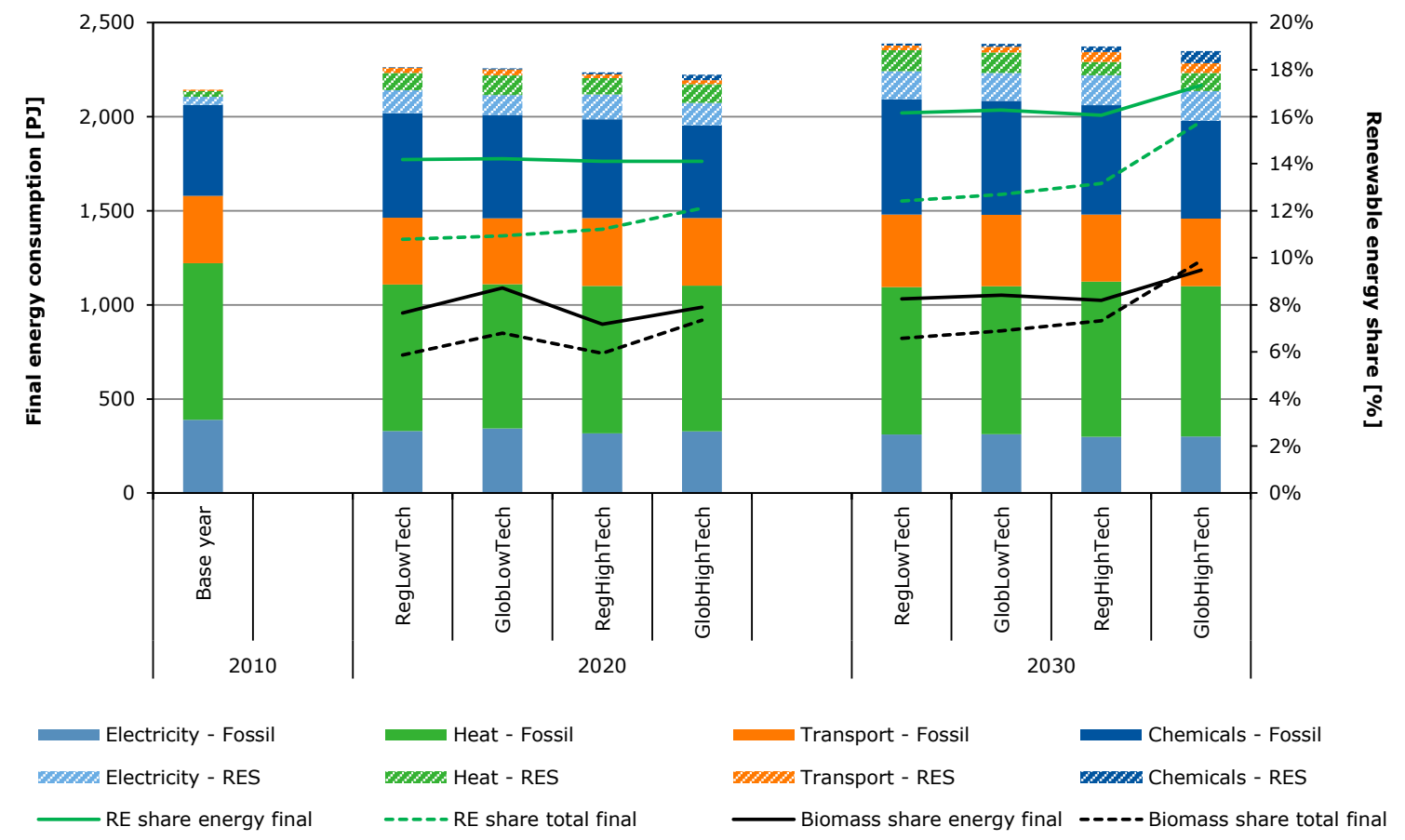

Figure 24 Final energy consumption for energy and non-energy purposes per sector (bars, left axis) and contribution of renewable energy and non-energy from renewable resources (lines, right axis) in the Netherlands in 2010-2030

- In 2020, the share of renewable energy in final energy consumption is $14 \%$, as mandated by the EU RED for the Netherlands. Despite moderate policies (e.g. $\mathrm{CO}_{2}$ tax), in 2030 the contribution increases to approximately $16 \%$ - again due to policy mandates (Dutch Energy Agreement), with the exception of the open trade scenario under high technology development assumptions where the renewable energy share reaches $17 \%$. This is a first indication that open trade and high technology development stimulate the cost-competitive diffusion of renewable energy to the Dutch energy system beyond policy levels, whereas in all other reference scenarios renewable energy is driven by policy mandates.

- When energy and non-energy uses are taken into account, the share of renewable energy drops slightly to $10-12 \%$ in 2020 and to $12-16 \%$ in 2030 . This is due to the high share of fossil feedstocks in the energy mix (490-550 PJ in 2020, 520-610 PJ in 2030). We also notice that the difference between biomass contribution in energy uses and in non-energy uses is lowest in high technology development scenarios (2020) compared to low technology development (difference between continuous black line and dotted black line in Figure 24). By 2030, in open trade scenarios coupled with rapid technology development this relationship is reversed, namely biomass contribution in renewable energy including non-energy uses is higher than biomass contribution only for energy purposes. This indicates the importance that the emerging sector of bio-based chemicals may have under such scenarios.

- Electricity from renewable resources is the largest contributor to the renewable energy share $(\sim 45-$ $55 \%$ across years and scenario variants, primarily due to the deployment of wind as expected by the Dutch Energy Agreement; see Section 1.3.2). Heat from biomass is the second largest source of renewable energy and is projected to contribute $25-45 \%$ to final energy from renewable resources (depending on year and scenario variant) with highest shares noticed in low technology development scenarios in 2030. Fuels make up the difference (fuels: 5-20\%). For fuels and chemicals, the contribution is largest in 2030 under high technology development assumptions. The above indicate the importance of wind in the electricity sector and of biomass in heat production in meeting renewable energy targets. By 2030, variation across the technology development axis points to competing and competitive uses of biomass in advanced applications (fuels, chemicals). 
- The role of biomass in delivering the energy services is significant as it accounts for $50-60 \%$ of the renewable energy share in 2020-2030. Regarding final energy and non-energy applications, heat is the single most important end-use of biomass (accounting for $40-75 \%$ of final energy from biomass, depending on scenario variant and year). As expected, higher shares of heat production are noticed in low technology development scenarios and early in the time horizon (2020), as in these scenarios there are limited technology alternatives for biomass conversion. Fuels and chemicals are the second largest supply sectors of biomass products (fuels: $10-30 \%$, chemicals: $2-30 \%$ ). Fuels and chemicals are the second largest supply sectors of biomass products (fuels: $10-30 \%$, chemicals: $2-30 \%$ ).

Note that aviation fuels are excluded from these figures as they are addressed separately in sectorspecific scenarios (see Section 5.1.5).

\section{Key message}

Fossil resources remain significant in final energy across all sectors. Electricity from renewable resources (primarily wind, largely supported by the Dutch Energy Agreement) and biomass heat contribute most towards meeting the EU RED's target for renewable energy share in 2020 and the Dutch Energy Agreements target on renewable energy share in 2030. Differences in technology development scenarios indicate lower value applications for biomass (i.e. heat) when technology alternatives are limited, while higher value applications become cost-competitive even beyond policy mandates if high technology growth pathways are followed. Results indicate the importance that accounting for non-energy uses of biomass can have in the future and is an early signal for future policymaking.

\subsubsection{Electricity technology mix}

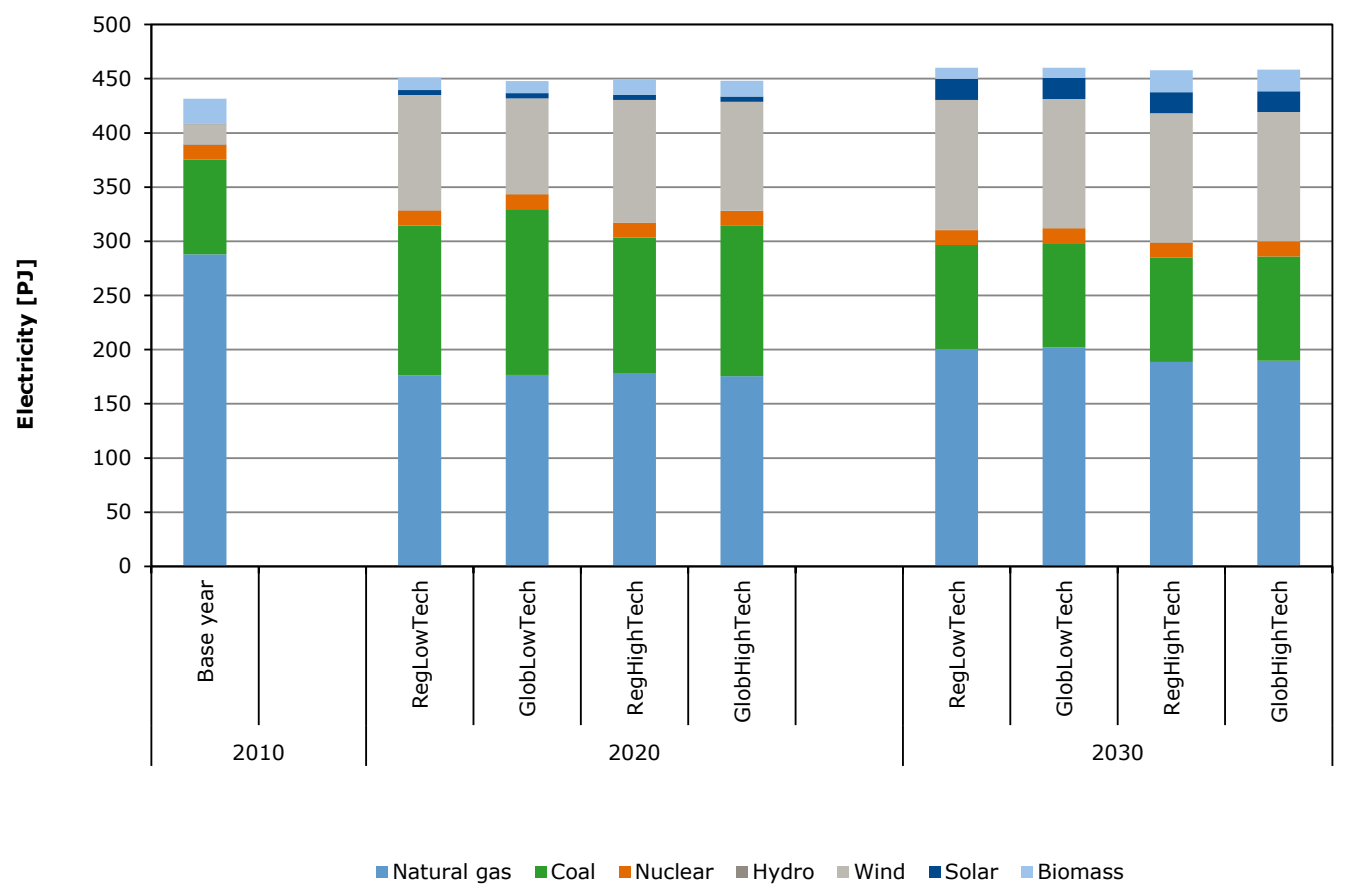

Figure 25 Electricity production by source in the Netherlands in 2010-2030

Figure 25 shows the production of electricity by source. Electricity from biomass is the aggregate of generated output by any conversion technology that consumes biomass, whether it is a dedicated plant (e.g. bio-CHP, organic fraction of $\mathrm{MSW}_{,}$, co-firing) or co-produced electricity by other conversion technologies (e.g. biorefinery):

- Fossil-based electricity production (primarily natural gas and coal) decreases significantly from $90 \%$ in 2010 to approximately $70 \%$ in 2020 and $65 \%$ in 2030 . The steep reduction occurs due to the 
strengthening of policies on renewable energy share, gradually increasing $\mathrm{CO}_{2}$ tax levels over the modelling period, and support of renewable energy technologies such as wind and solar. It is interesting to note the decrease in coal between 2020 and 2030, which occurs as a result of more cost-efficient electricity generation from natural gas in combination with $\mathrm{CO}_{2}$ emission tax levels of 2030.

- Prominent is the output from wind turbines ( 105 PJe in 2020 and 120 PJe in 2030 based on capacities largely supported by the Dutch Energy Agreement - deployment of offshore wind is exclusively based on the agreement's support (i.e. installed capacity does not exceed the agreement's levels), while for onshore wind, $2 \mathrm{GW}$ of additional onshore wind capacity is installed in the modelling period.

- Electricity output from biomass ranges from 11-14 PJ in 2020 to 9-20 PJ in 2030, mainly as an output of MSWI and bio-CHP plants ( $10 \mathrm{PJ}$ in 2030$)$ and co-generation in fuel conversion technologies ( $\sim 2 \mathrm{PJ}$ in low and $\sim 10 \mathrm{PJ}$ in high technology development scenarios in 2030). It is interesting to note that co-firing of solid biomass in coal power plants does not occur beyond 2015, with the exception of open trade scenario coupled with high technology development growth where approximately $2 \mathrm{PJ}$ are from co-firing. This makes the co-firing cap of the Dutch Energy Agreement less relevant.

\section{Key message}

The two key outcomes for the electricity sector are the high contribution of wind in renewable electricity and the gradual shift from coal- to natural gas-based electricity by 2030 . Electricity from biomass is limited and mainly from incineration of the organic fraction of municipal solid waste and cogenerated electricity from biorefineries, which is largest in high technology development scenarios.

\subsubsection{Renewable heat technology mix}

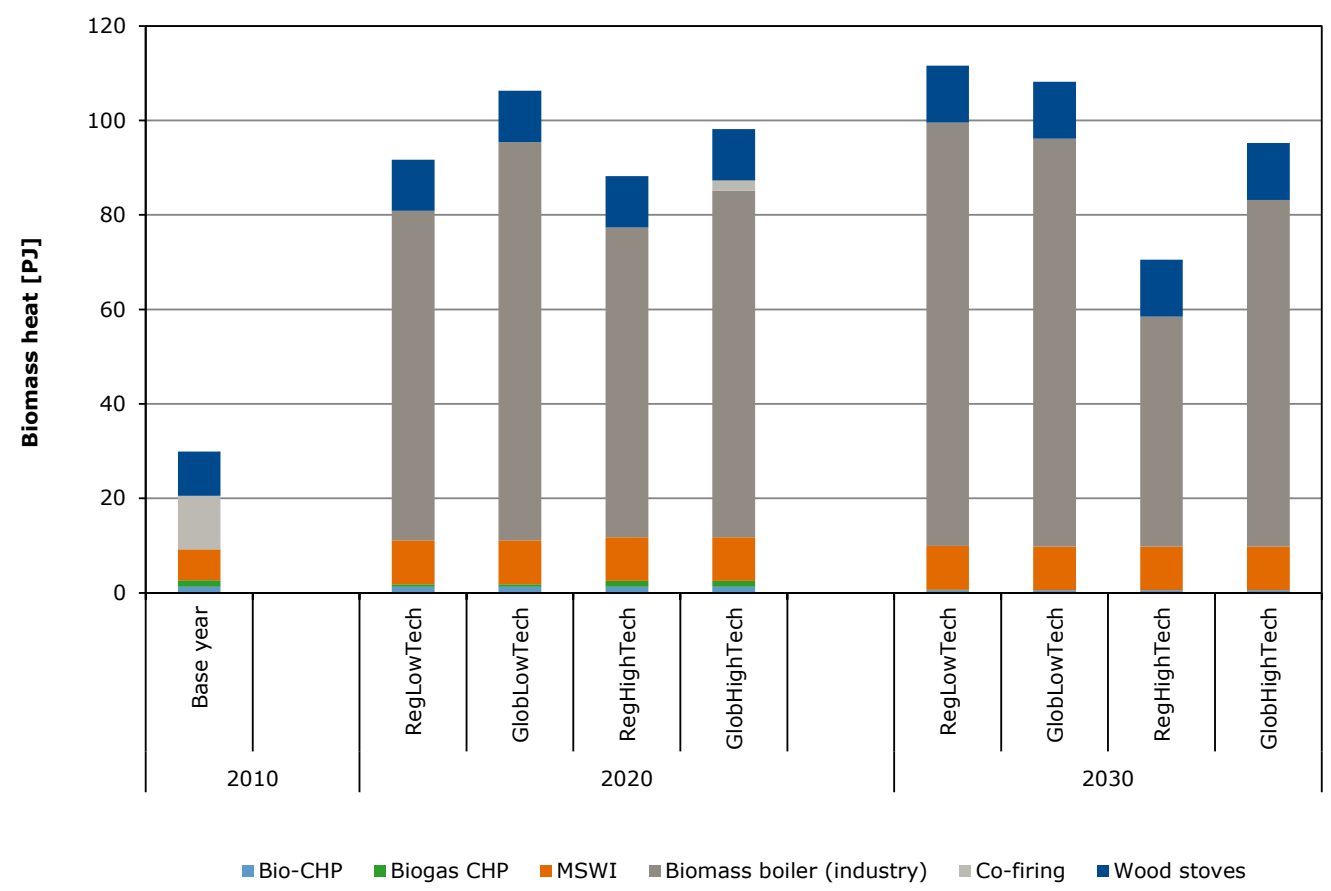

Figure 26 Biomass heat production by technology in the Netherlands in 2010-2030

Figure 26 shows heat production from biomass:

- Renewable heat increases by a factor of 2-4 depending on the scenario variant (i.e. from $30 \mathrm{PJ}$ in 2010 to as much as $110 \mathrm{PJ}$ in 2030). Heat from biomass boilers in industry accounts for $70-90 \%$ of total renewable heat output. The remainder comes from firewood use in wood burning stoves and 
the organic fraction of waste in MSWI, which co-produce heat and electricity ( $10 \mathrm{PJ}$ heat output by each technology).

- Regarding variation of biomass heat across the scenarios, low technology development scenarios show a larger output compared to the corresponding high technology development scenarios by 10-40 PJ in 2030. This is expected, as fewer competing technologies are available in low technology development scenarios compared to high technology development to meet the EU RED renewable energy share target which makes biomass heat a more cost-effective alternative.

- High-tech development coupled with regional trade shows the lowest biomass heat output from industrial boilers by 2030 . The underlying reason is that competitive production of FT fuels for road transport also contribute to the EU RED renewable energy target, which makes higher levels of biomass heat production not competitive to meet targets. In contrast, open trade opens the supply of low cost biomass for both sectors (heat, transport fuels).

- The remainder of heat demand is supplied primarily by natural gas ( $870 \mathrm{PJ})$.

\section{Key message}

While natural gas remains a key energy carrier in delivering heat to end-use sectors, the deployment of biomass boilers in industry is significant as it is one of the most cost-efficient options to meet EU RED targets at a system level. Other technologies that also contribute to delivering biomass heat are co-generated heat from the incineration of municipal solid waste and traditional fuelwood use in wood burning stoves.

\subsubsection{Transport technology mix}

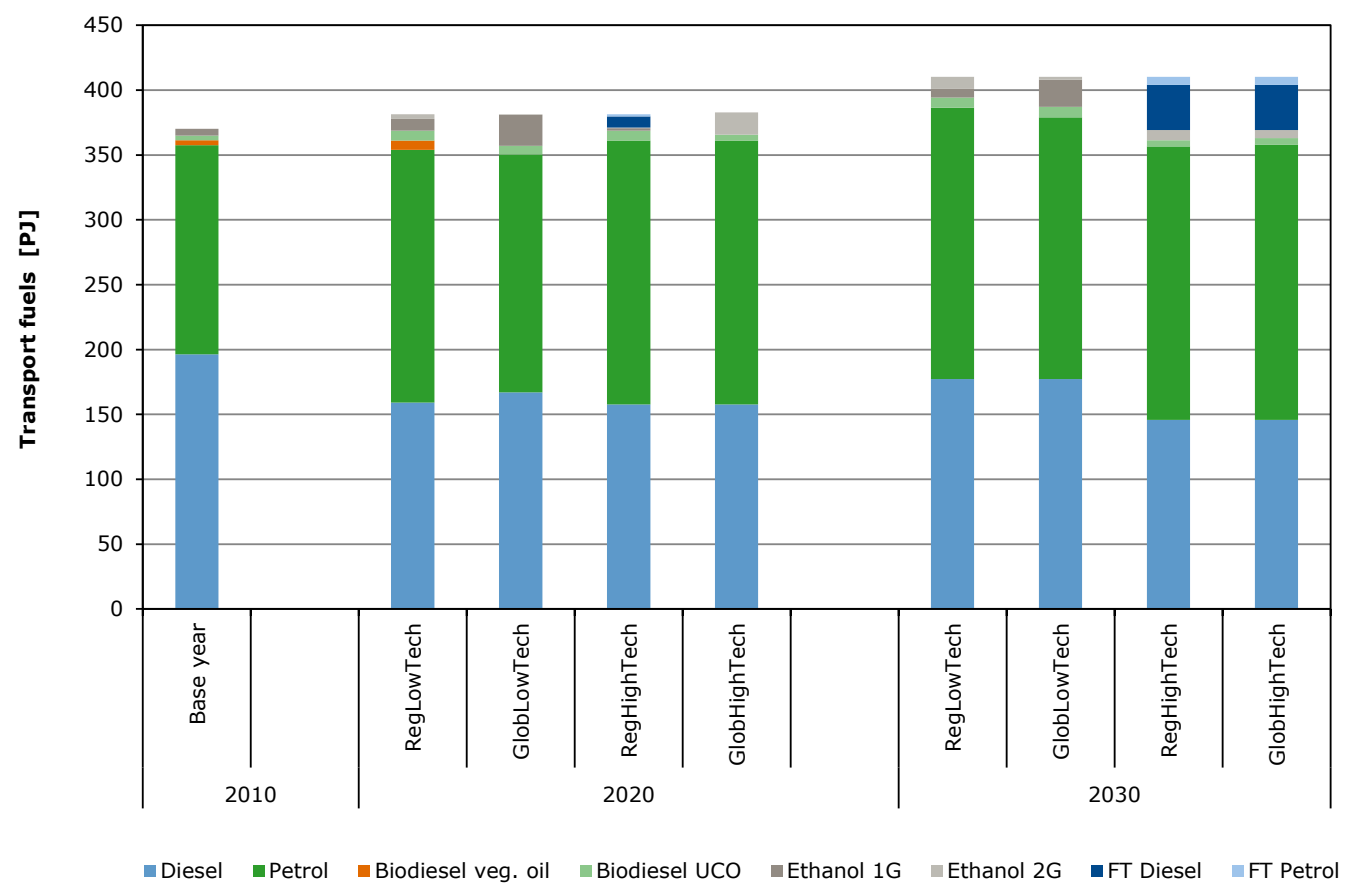

Figure 27 Road transport fuels in the Netherlands in 2020-2030

Figure 27 shows the road transport fuels consumed in the Netherlands. The primary driver for biofuels in 2020 is the blending target as outlined in the EU RED.

- The total final fuel required to meet demand for road transport is approximately $380 \mathrm{PJ}$ in 2020 and $410 \mathrm{PJ}$ in 2030. In 2020, 92-95\% of road transport fuels is fossil diesel and petrol-biofuels are blended to reach the blending target. In low technology development scenarios, biofuels are mainly first-generation ethanol and biodiesel from used cooking oil ( 15-30 PJ) and in high technology 
development scenarios FT fuels are supplied ( $10 \mathrm{PJ})$ at the expense of first-generation ethanol and biodiesel from vegetable oil.

- In 2030, as the policy driver of blending share remains, the regional low technology development scenario meets the blending target mainly by second-generation ethanol and biodiesel from used cooking oil. However, open trade allows large imports of first-generation ethanol ( $20 \mathrm{PJ})$ as they are found more cost-efficient than importing or deploying domestically other options (e.g.

lignocellulosic ethanol, vegetable oil biodiesel). In low technology development scenarios, biodiesel from used cooing oil remains unaffected across the trade axis. In high technology development scenarios, more cost-efficient ethanol production from solid biomass enables the use of ethanol in the road transport sector. First-generation ethanol is not used at all (in contrast to low technology development scenarios) and biodiesel consumption from used cooking oil also decreases. The dominant renewable fuels come from FT technologies, which in total supply roughly 40 PJ of road transport fuels. It should be noted that in high technology development scenarios (both in regional and open trade), the blending target of $10 \%$ is exceeded by $13 \%$ pp (excluding double counting). The reason is that renewable road transport fuels also contribute to the share of renewable energy in final energy consumption and the model estimates most cost-efficient compliance with the target by supplying larger FT fuel quantities (and co-generated electricity).

- It should also be noted that the $\mathrm{CO}_{2}$ tax also affects emissions from the transport sector (exhaust pipe emissions). Note that the targets set in the Dutch Energy Agreement to reduce emissions in the transport sector are not included in the scenarios.

\section{Key message}

Due to the double-counting of biofuels from waste biomass in the EU RED's biofuel blending mandate, in the transport fuel mix biodiesel from used cooking oil is produced across all scenarios and time periods. However, technology development rates affect the production technologies for the remaining biofuel mix. First-generation biofuels are key in low technology development scenarios, while FT fuels and second-generation ethanol are key in high technology development. By 2020, the biofuel supply is exclusively driven by the blending target. However, by 2030 trade and technology assumptions create a more versatile picture: lignocellulosic ethanol is produced domestically if accelerated development is achieved or in regional trade conditions when slower rates of technology development are followed. The cost-efficient production of FT fuels, however, increases the biofuel mix above the blending target, also counting towards the renewable energy share. 


\subsubsection{Chemical technology mix}

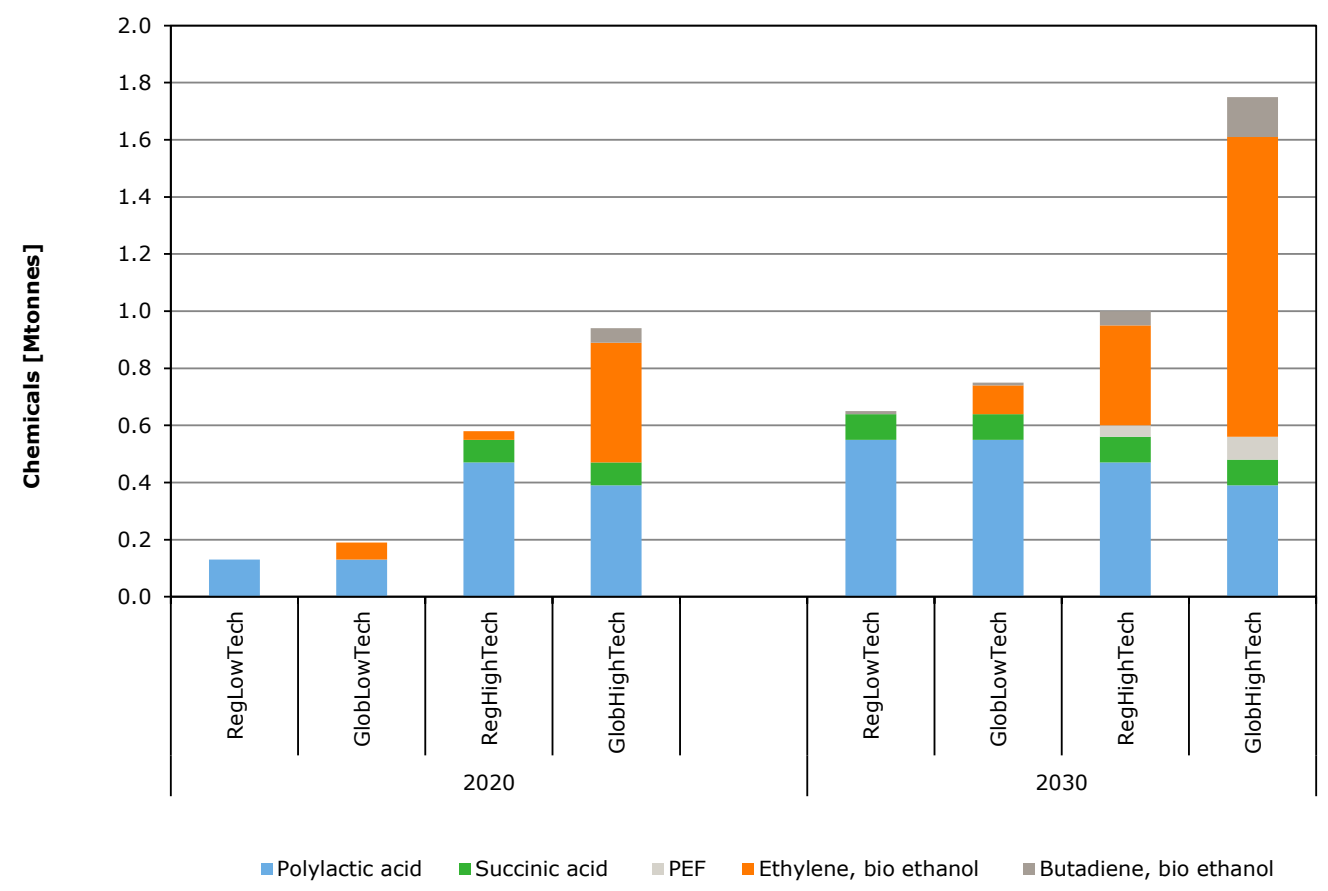

Figure 28 Bio-based chemical output in the Netherlands per type ( $m t$ )

Figure 28 shows the bio-based chemical output in the Netherlands.

- Key products/technologies highlighted are the production of polylactic acid and bio-based ethylene from ethanol.

- It is shown that approximately $150-550 \mathrm{kt}$ of PLA can be produced, which corresponds to 210-780 kt of sugar consumed. Across low technology development scenarios, no significant variation in PLA production is within the same time period. In high technology development scenarios, depending on trade openness, PLA output is affected by approximately $100 \mathrm{kt}$ : open trade favours the production of ethylene from ethanol, which slightly reduces the competitiveness of PLA, as they are assumed to compete in similar markets. At the same time, in 2030 the availability of PEF competes with PLA, and similarly, open trade conditions make PLA less competitive in comparison to the other bio-based alternatives. Competition due to access to feedstock (trade axis) starts as early as 2020 under high technology development scenarios. Nevertheless, this outcome signals the cost-efficient production of PLA if sugar prices (the key determinant of production costs) are at the levels assumed in this study.

- Bio-based ethylene from ethanol appears to be a winning technology in the long term, in high technology development scenarios, where larger scales can be deployed, or already by 2020 if open trade scenarios are assumed. By 2030, the output increases significantly to as much as $1 \mathrm{mt}$ (in high technology development scenarios with open trade), which is roughly $1 / 3$ of today's fossil ethylene output. Such production levels are enabled by the deployment of second-generation ethanol technologies in the Netherlands, low costs of imported second-generation ethanol, and the availability and mobilization of low-cost EU feedstocks.

- Production of butadiene (also ethanol-based) is also noticed. The reasoning is similar to the above.

- Succinic acid, despite being available as a technology across all scenarios, emerges in 2020 only under high technology development scenario assumptions. In 2030, production is noticed across all scenarios at similar levels. 
- Finally, PEF from second-generation feedstocks, which is available only beyond 2025 in high technology development scenarios, emerges under both trade assumptions. The production volume is slightly higher in open trade scenarios (twice the activity noticed in regional trade). It should be noted again that PEF, PLA and bio-ethylene compete in the same markets, and trade-offs in activity levels of the respective technologies are noticed.

- It should be noted that reference scenarios assume an increase in demand for chemicals. Based on MAGNET outcomes, chemical industry output is projected to decrease by $10 \%$ in 2030 compared to 2007. The sensitivity of bio-based chemical output to projected demand and variation of fossil fuel prices is assessed in Sections 5.1.1 and 5.1.5.

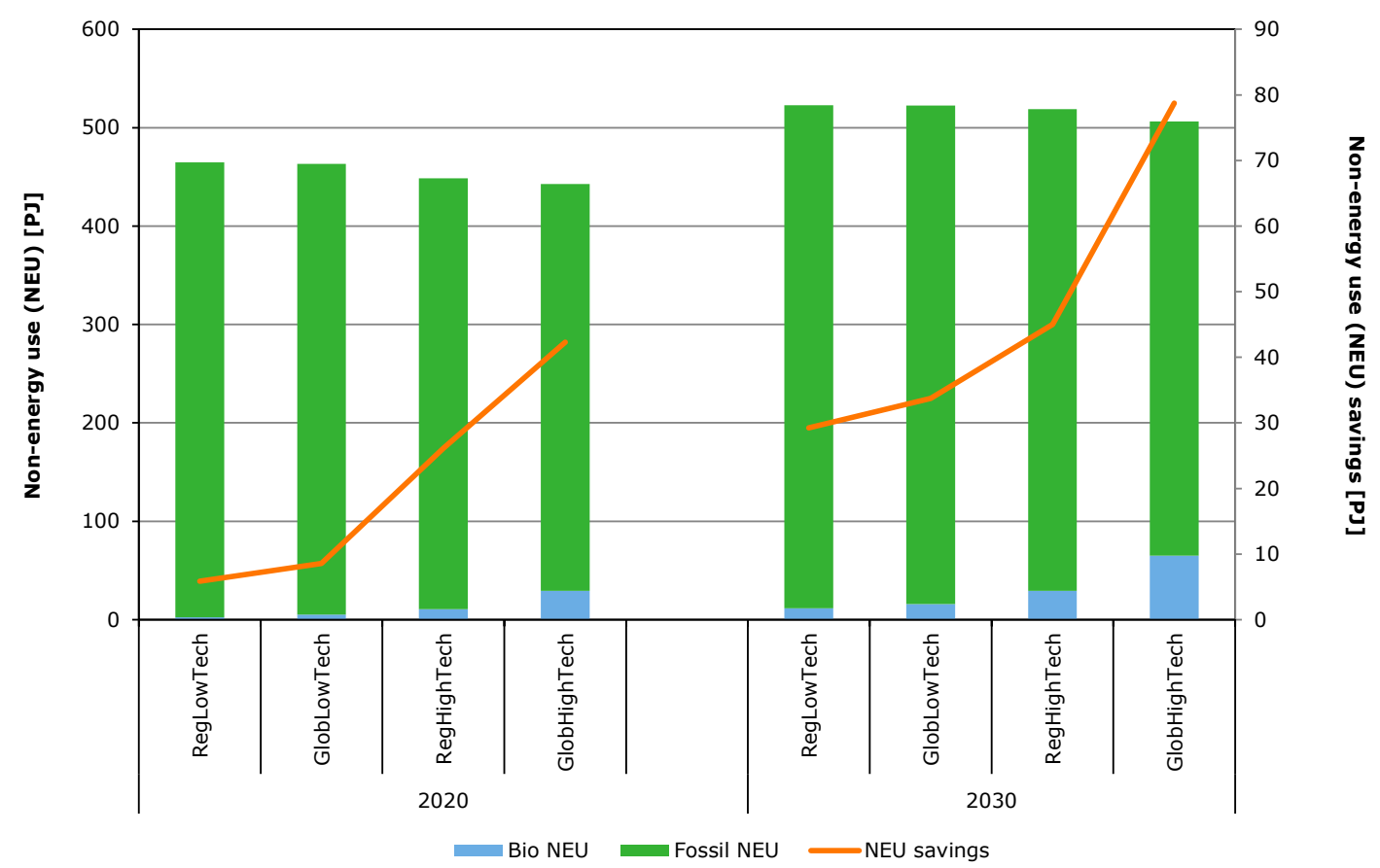

Figure 29 Fossil and bio-based energy use for chemicals in the Netherlands in 2020-2030 (bars; left axis). Fossil energy savings are also estimated (lines; right axis)

Figure 29 focuses on non-energy use in the Netherlands of fuel from fossil and bio-based resources. It shows the savings in fossil energy that occur due to bio-based chemicals production. As the estimate of the bio-based non-energy use (NEU) is based on heating values of final products, the fossil NEU savings are also determined in a similar manner (as opposed to deploying a counterfactual scenario where no bio-based chemicals production is allowed). Figure 29 shows that the greatest savings occur in open trade scenarios under high technology development assumptions, which represent a $13 \%$ nonenergy use from biomass. Low technology development and trade openness lead to similar savings (little variation).

\section{Key message}

Sugar prices drive bio-based chemical production as the production of polylactic acid is present across all scenarios and time periods. However, early in the time horizon, production output is affected by assumed technology development rates. Furthermore, technology development also affects the deployment of competing alternatives such as bio-based ethylene from ethanol, which in combination with open trade scenarios can become a key bio-based polymer, supplying significant share of the projected demand. Key to the deployment of chemicals and similar to the deployment of biofuels are technological advances in lignocellulose conversion to ethanol and sugar in combination with low feedstock costs. These developments favour the production of bulk chemicals. However, as shown 
later on, demand projections and variation in fossil fuel prices are key determinants of bio-based chemical output.

\subsubsection{Demand for biomass}
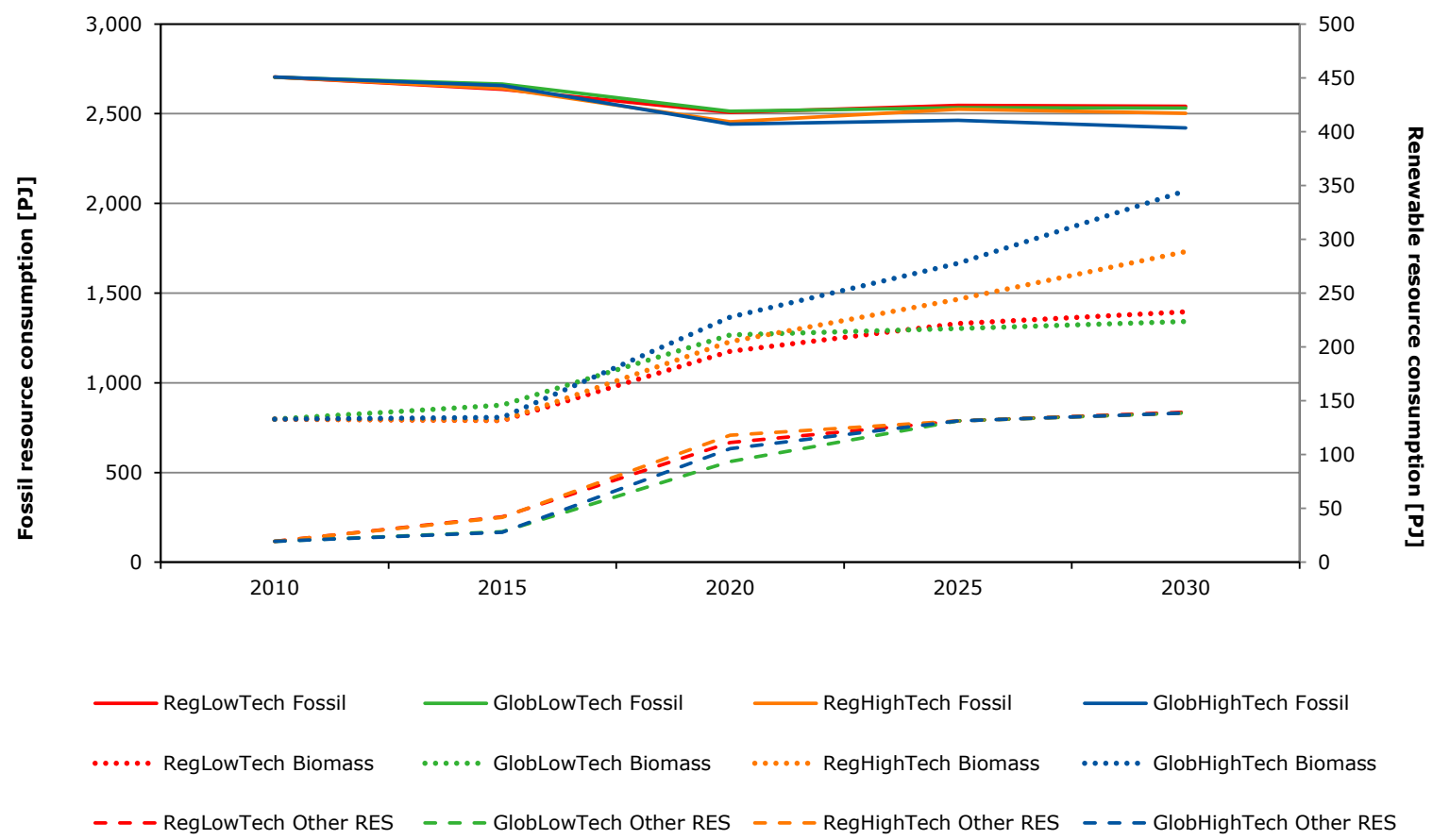

Figure $\mathbf{3 0}^{\mathbf{1 3}}$ Primary energy consumption. Left axis: fossil; right axis: biomass and other renewable energy in the Netherlands in 2010-2030 (1PJwind/solar/hydro=1PJel)

Figure 30 shows resource consumption in the Netherlands in 2010-2030 for the sectors included in MARKAL-NL-UU. Fossil resources include natural gas, coal, oil (fuels, naphtha and chemicals), the fossil fraction of municipal solid waste and uranium used in nuclear power reactors. Biomass includes domestic and imported feedstocks of different types expressed as primary energy (prior conversion to final uses). 'Other renewable energy sources (RES)' include wind, solar and hydro. ${ }^{13}$

- Total primary energy consumption is projected to increase by approximately $1-3 \%$ in 2030 compared to 2010 . As fossil resource consumption decreases by $6-11 \%$ in 2030 compared to 2010 , the increased demand and decreased supply of fossil energy are met by renewable resources. The highest reduction is seen in high technology development scenarios due to higher technology efficiencies assumed in the petrochemical industry and the greater availability of advanced fuel and chemical conversion technologies, compared to low technology development scenarios. However, the overall difference is small.

- Overall, no difference is found between technology development scenarios regarding renewable resources, except for total biomass consumption (methodological implication: the technology development scenarios concern biofuel, bio-based chemical and petrochemical industry technologies). High technology development scenarios show higher biomass consumption compared to low technology development scenarios (around 10-15 PJ in 2020, increasing to around 55-120 PJ by 2030). The smallest difference between technology development scenarios occurs under regional trade assumptions. This entails that constraints in low-cost biomass supply have an effect on total

\footnotetext{
131 PJprim of wind, solar and hydro equals 1 PJel, i.e. primary energy = final energy. This is not the case for biomass, where efficiency losses are taken into account.
} 
biomass consumption especially if coupled with rapid technology development. Scenario assumptions have no influence on other renewables.

- In low technology development scenarios beyond 2015, biomass consumption increases by $3-4 \%$ p.a., while in high technology development scenarios the growth rate is 5.5-6.5\% p.a. International trade in combination with high technology development indicates highest biomass consumption $(\sim 345 \mathrm{PJ})$.

- In other renewables, wind makes the most significant contribution ( 105 PJ in 2020 and 120 PJ in 2030). This is primarily driven by the Dutch Energy aAreement. Across all scenarios, this corresponds to additional $2 \mathrm{GW}$ of onshore wind capacity installed by 2030, compared to the Dutch Energy Agreement's announcements. Solar energy capacity does not increase to levels beyond the agreement.

\section{Key message}

Across time and scenarios, the use of fossil energy resources decreases at similar rates. Also, similar growth is noticed in other renewables, as wind and solar are supported by the Dutch Energy Agreement. In the reference scenarios, the primary use of biomass ranges from 230 to $345 \mathrm{PJ}$, with the highest consumption in open trade conditions coupled with strong technology development rates. One notable exception regarding trade effects is in low technology development scenarios, where regional trade indicates slightly higher biomass consumption than open trade scenarios. This is due to the model choice to import first-generation ethanol if access to global markets is assumed, as opposed to deploying less efficient (in terms of primary energy) second-generation ethanol technologies for road transport fuels, as is the case in regional trade scenarios. ${ }^{14}$

\subsubsection{Biomass consumption per end-use sector}

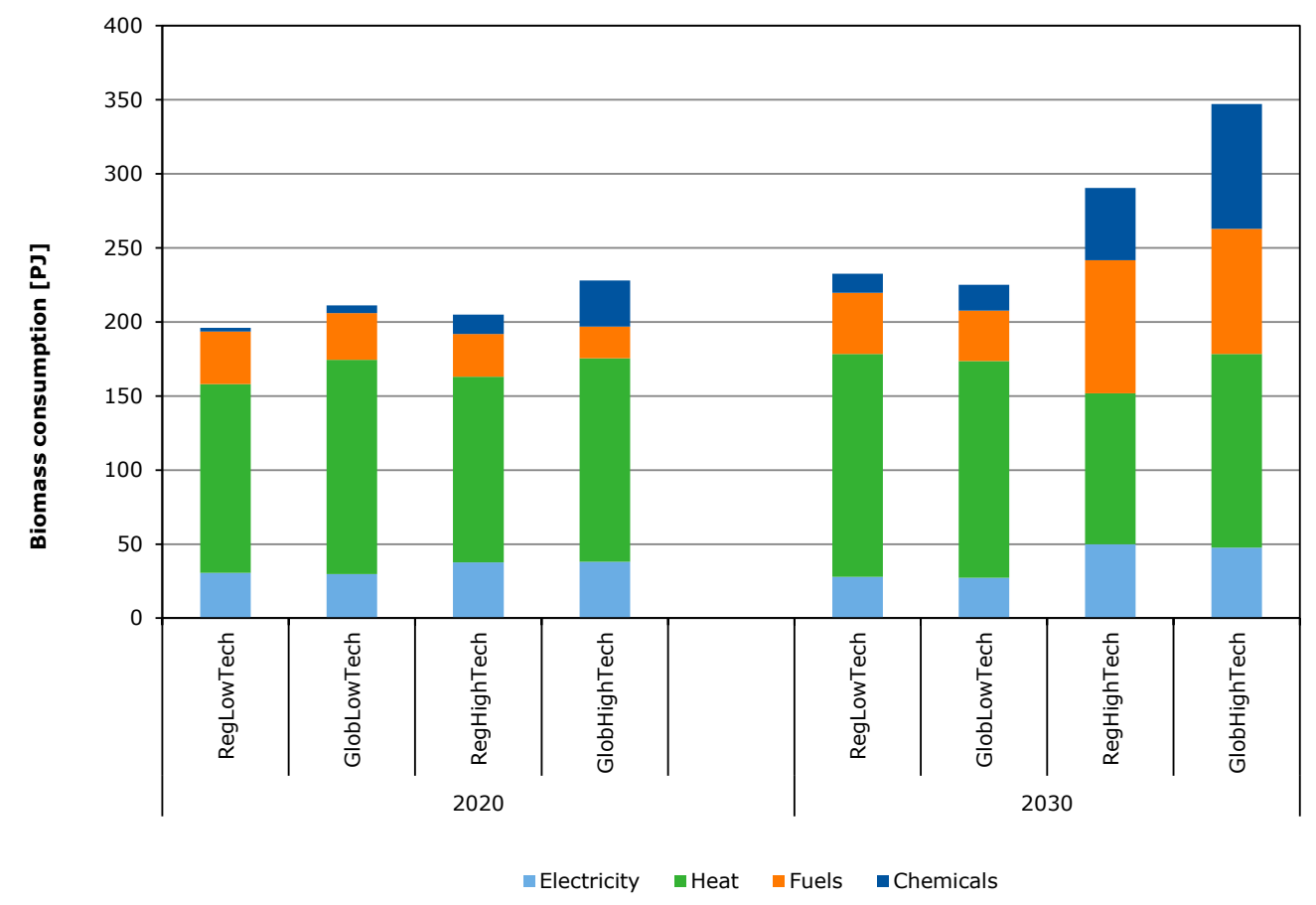

Figure 31 Biomass consumption per sector in the Netherlands in 2020-2030

Figure 31 presents biomass in terms of primary energy at the key sectors in which it is consumed ${ }^{15}$.

\footnotetext{
${ }_{15}^{14} 1 \mathrm{GJ}_{\text {imported ethanol global markets }}=1 \mathrm{GJ}$ primary energy.

${ }^{15}$ Biomass resources that are used in co-production and bio-refining technologies have been allocated to each sector based on energy allocation of the end-use products they produce. The technology types are CHPs, gasification and FT fuel synthesis, lignocellulosic ethanol/sugar and bio-based chemicals.
} 
- The heat sector consumes most of the biomass (100-150 PJ, or 35-70\% of total biomass consumption). ${ }^{16}$ As discussed earlier, low technology development scenarios consume larger biomass quantities for heat than high technology development scenarios due to the limited options to meet the EU RED renewable energy target.

- Biomass consumed for electricity generation is relatively stable across scenarios (30-50 PJ, or $12-18 \%$ of total biomass consumption) and is mainly attributed to MSWI. High technology development scenarios show larger biomass consumption by the electricity sector due to cogenerated electricity from bio-refineries( 12 PJ in 2030).

- The transport fuel sector consumes approximately 20-35 PJ of biomass in 2020 and 35-90 PJ in 2030. One notable pattern is that open trade scenarios consume 7-25\% less biomass for transport fuels in 2020 due to imported ethanol instead of lignocellulose or starch for conversion in the Netherlands. In 2030, biomass consumed for transport remains relatively stable in low technology development scenarios, while it increases by 3-4 times in high technology development scenarios as large quantities of FT fuels are produced from lignocellulose. Trade assumptions do not affect biomass consumption under high technology development scenarios as there is sufficient low-cost biomass available.

- Relatively small quantities of biomass are consumed by the chemical sector in 2020 (2-13 PJ; or 2$6 \%$ ), with the exception of high technology development scenarios in combination with open trade where low-cost ethanol is available for further downstream conversion in the Netherlands. In 2030, the chemical sector increases its consumption especially in high technology development scenarios by a factor of 2.5-5. By 2030, large scales of technologies in combination with low-cost lignocellulosic feedstocks for sugar production, raw sugar and ethanol make such an increase in consumption levels possible. For biomass consumption in the chemical sector, technology development is a key determinant as the difference from high technology development amounts to $65 \mathrm{PJ}$. However, under high technology development scenarios, assumptions on trade are also significant as they lead to a variation of $35 \mathrm{PJ}$.

\section{Key message}

Due to the significant capacities of co-production technologies deployed, either as co-generation technologies from small-scale CHPs to MSWI or advanced biorefineries, but also due to flows of feedstocks such as ethanol to different sectors, allocating primary biomass use to end-use sectors is important to highlight synergies and competition of biomass resources. While the picture for 2020 is relatively stable across scenarios (with the exception of high technology development scenarios where larger shares of biomass are used for the production of chemicals compared to all other reference scenarios), it changes by 2030. In high technology development scenarios, biomass for heat is reduced while biomass for electricity, fuels and chemicals (mainly through biochemical refinery routes or gasification technologies) increases compared to low technology development scenarios. Similar to other indicators assessed in this study, this points to the significance of second-generation technologies that process lignocellulosic feedstocks for large-scale cost-effective bio-based economy in the Netherlands.

\footnotetext{
${ }^{16}$ Industrial natural gas boilers are assumed to be depreciated (no investment costs required). In contrast, to supply heat from biomass, investments are required. Therefore in the heat sector, it is more cost-efficient to supply heat from natural gas. However, due to the EU RED mandate on $14 \%$ renewable energy supply and the $16 \%$ renewable supply share of the Dutch Energy Agreement, the model found as most cost-effective the deployment of biomass boilers to meet targets compared to other renewable energy options.
} 


\subsubsection{Biomass consumption per feedstock}

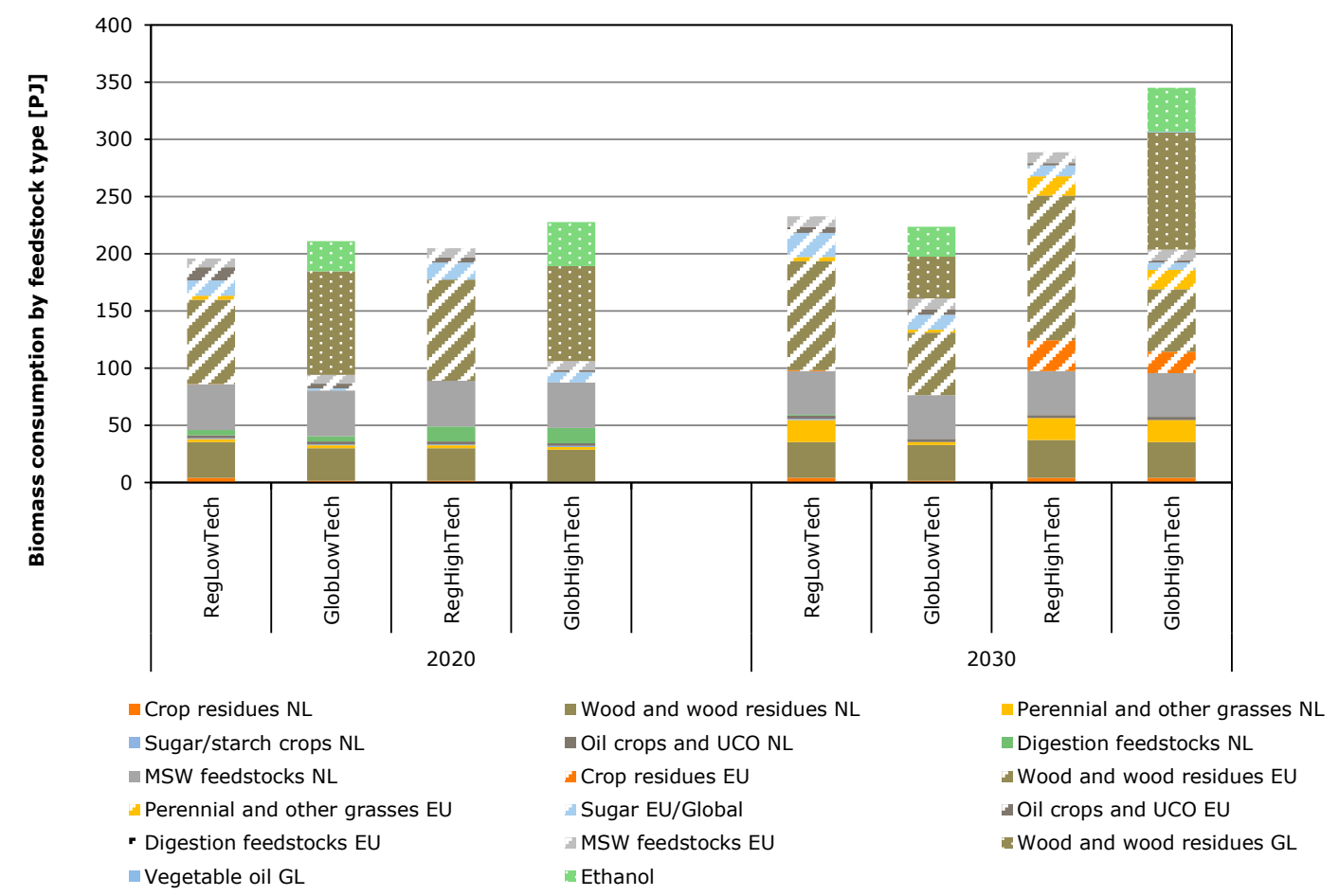

Figure 32 Biomass consumption in the Netherlands in 2020-2030 by feedstock type. Note that solid colours indicate domestic resources, line patterns indicate imports from the EU and dotted patterns indicate imports from global markets. In global trade scenarios sugar is not distinguished whether it is sourced from EU or global markets

Figure 32 presents biomass consumption levels in each scenario quadrant and distinguishes the feedstock types consumed and the region of origin (domestic, EU, global).

- The first observation is that more than $55 \%$ of resources originate from regions outside the Netherlands (110-250 PJ) while the remaining 75-100 PJ originate from domestic resources. From the total $150-170 \mathrm{PJ}$ of domestic biomass available, $50-60 \%$ are cost-effective to be used for conversion in the Dutch energy and industry system (Figure 33). ${ }^{17}$

- In 2020, there is a clear switch from regional resources to global biomass commodities (namely wood and wood residues, sugar and ethanol) of approximately $100 \mathrm{PJ}$ regardless of technology assumptions. Global trade does not affect domestic biomass consumption in 2020. In 2030, sourcing of EU biomass resources increases but the impact of global trade continues (albeit moderated to about 50-80 PJ). Note that since EU sugar/starch in international trade scenarios has the same costprice as global sugar, its origin is not distinguished.

- Forestry products and residues and wood from short rotation forestry are by far the most consumed feedstock across all scenarios, accounting for approximately $50-55 \%$ of total biomass consumption. This resource is consumed primarily in industrial biomass boilers for heat generation, gasification and second-generation ethanol/sugar technologies.

\footnotetext{
${ }^{17}$ The overall domestic biomass supply potential incorporated in the bottom-up model is $162 \mathrm{PJ}$ in 2020 and $181 \mathrm{PJ}$ in 2030 (based on Biomass Futures, including fuelwood for wood stoves which is added ad hoc), of which approximately $5 \%$ is assumed to be of low quality and non-utilizable (e.g. apples and pears, cherries and other soft fruit). This results in net domestic biomass availability of $153 \mathrm{PJ}$ (2020) and $172 \mathrm{PJ}$ (2030) (Section 3.3.2). Other studies, indicate a higher domestic potential of 215-290 PJ in 2020 (Koppejan et al., 2009), which is addressed in the discussion section of this study (Section 6). A direct implication of the latter is the large quantities of wet manure and other digestion feedstocks (55 PJ), which require treatment (and subsequently generate biogas). Nevertheless, this pathway (i.e. anaerobic digestion) is not selected as a cost-efficient option. Its utilization is assessed separately in section 5.1.2.
} 
- There is a significant increase in the consumption of perennial grasses and crop residues in high technology development scenarios from roughly 2-4 PJ in 2020 to approximately 60-65 PJ in 2030. Low feedstock cost-prices in combination with technological advances assumed in this scenario enable the deployment of second-generation ethanol production technologies. Crop residues become a cost-effective feedstock only under high technology development scenarios (in 2030).

\section{Key message}

Domestic solid biomass resources are found to be cost efficient and are almost fully utilized across all trade and technology scenario variants. Large unutilized potential is for wet biomass resources that are primarily used for digestion. Notable is the switch from EU to global resources, which offers additional low-cost biomass supply.

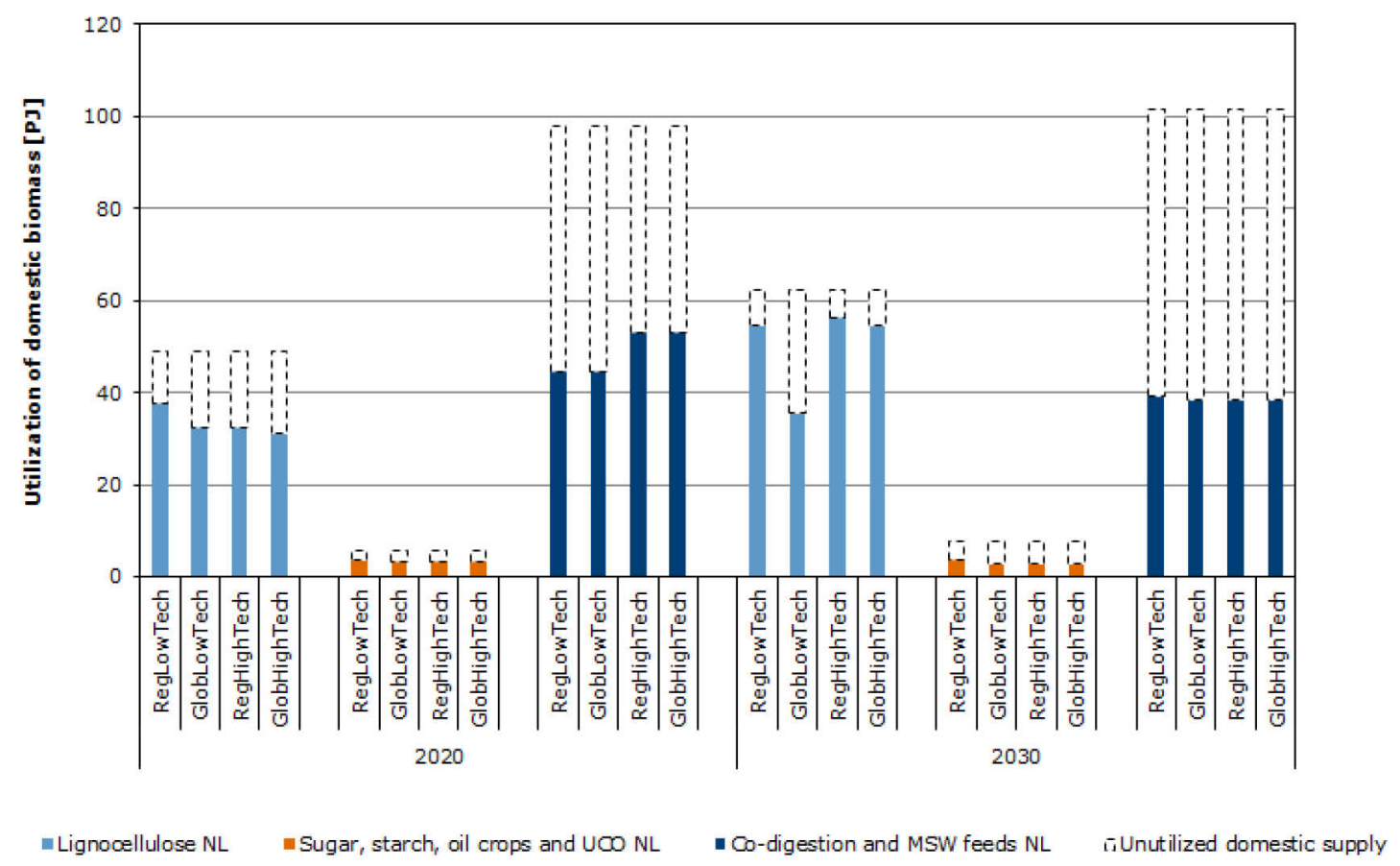

Figure 33 Domestic biomass feedstock utilization per feedstock category in the Netherlands in 2020-2030 


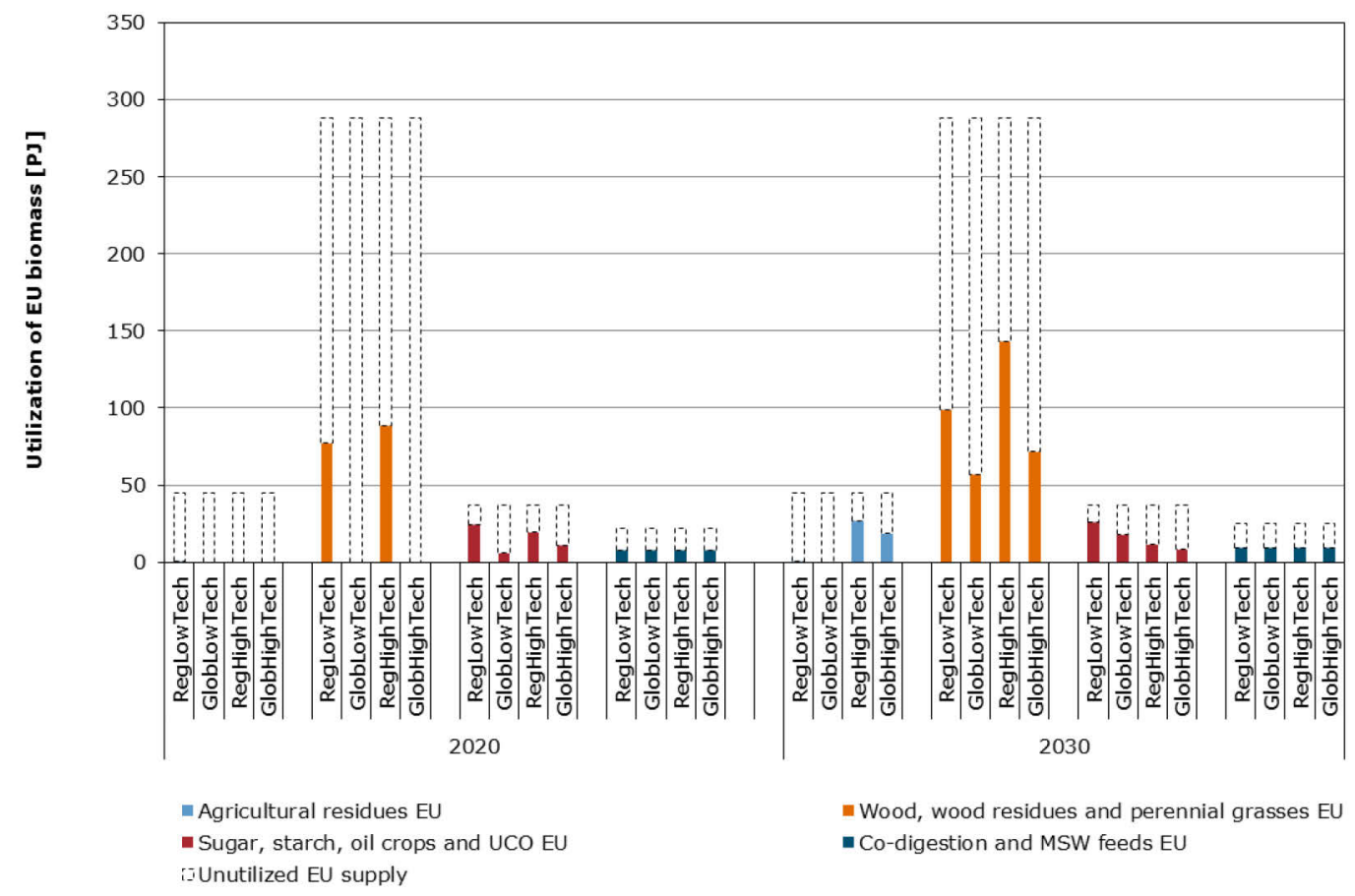

Figure 34 Biomass feedstock utilization from the EU per feedstock category in the Netherlands in 2020-2030

\subsubsection{Biomass consumption in biorefineries}

Figure 35 and Figure 36 show the consumption of lignocellulose in advanced biorefineries for lignocellulosic sugar and ethanol production, respectively. Ranges are also shown (error bars) to indicate the highest and lowest consumption levels across the various scenarios, which are assessed in Section 5. Results are presented in $\mathrm{mt}$ of wood pellet equivalents (w.p.e.) assuming $17.1 \mathrm{GJ} / \mathrm{t} \mathrm{LHV.}$

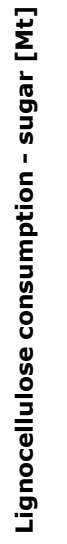

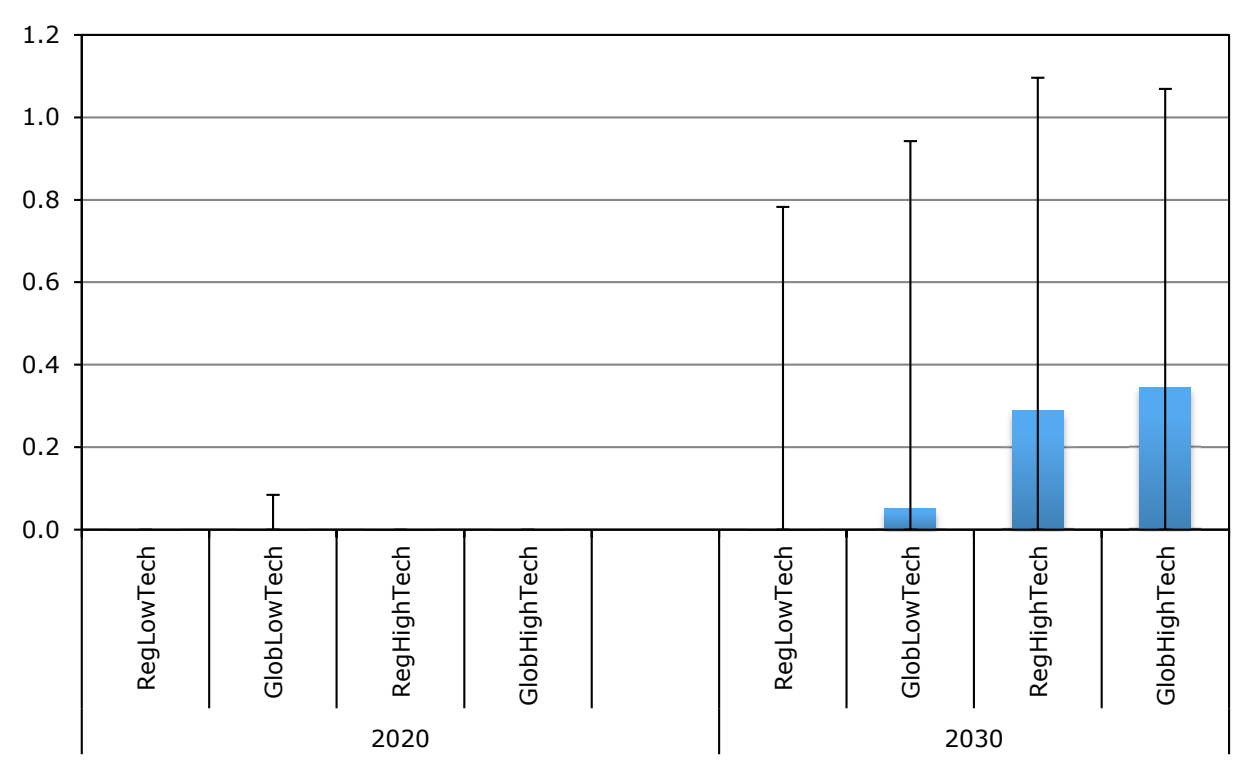

Figure 35 Lignocellulose consumption in advanced biorefineries for sugar production in $m t_{\text {w.p.e. in }}$ the Netherlands in 2020-2030 


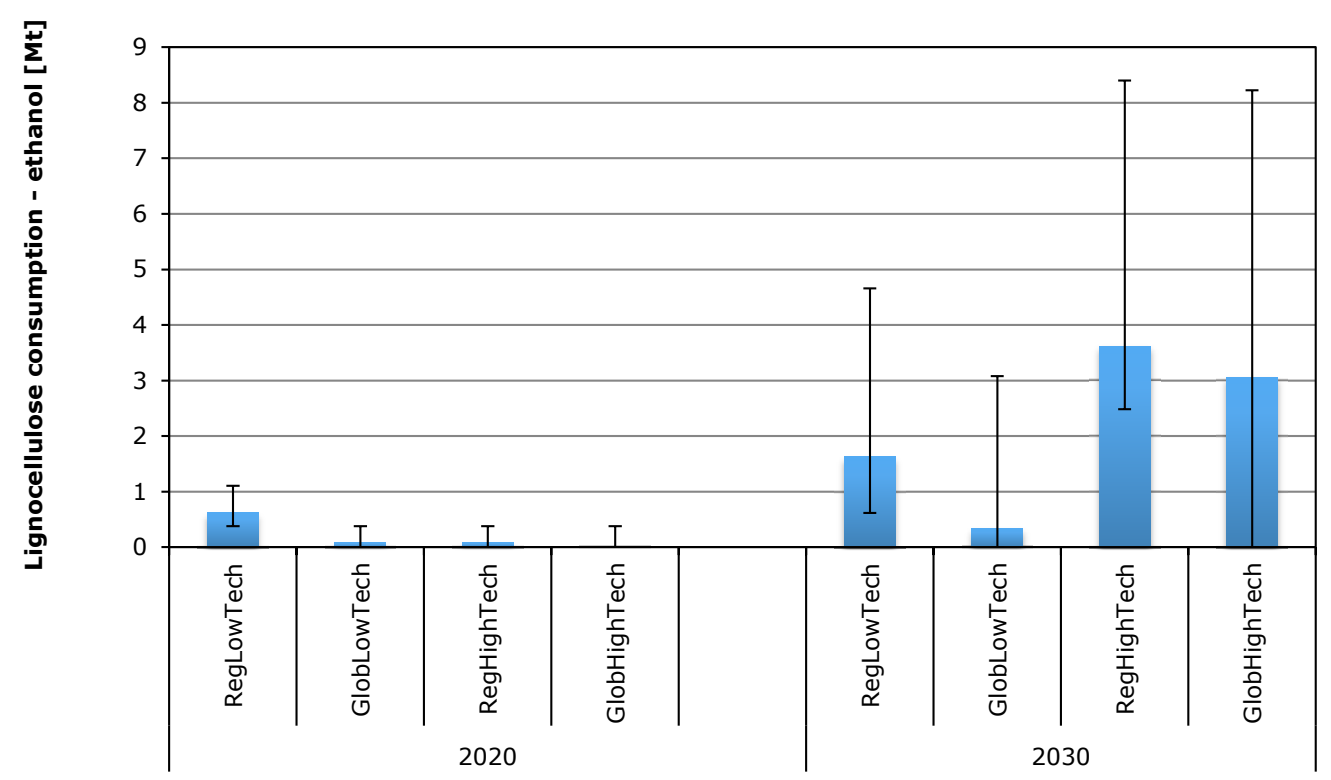

Figure 36 Lignocellulose consumption in advanced biorefineries for ethanol production in $m t$ w.p.e. in the Netherlands in 2020-2030

- The combined capacity of sugar and ethanol biorefineries amounts to $0.7 \mathrm{mt}$ input in 2020 and is mainly attributed to ethanol production.

- By 2030, the capacity ranges from $0.4 \mathrm{mt}$ input to approximately $4 \mathrm{mt}$ in the reference scenarios, with ethanol biorefineries consuming the lion's share of lignocellulose.

- Upper ranges (which can be considered extreme) indicate $1 \mathrm{mt}$ input of lignocellulose for sugar biorefineries and $16 \mathrm{mt}$ input of lignocellulose for ethanol biorefineries. These outputs are obtained for extreme scenarios such as low domestic biomass supply (in the case of sugar biorefinery) and high fossil fuel prices (in the case of ethanol biorefinery).

- Consumption by thermochemical refineries (gasification and conversion to FT fuels) is approximately $5 \mathrm{mt}$ in the reference scenarios. Similar to biochemical refineries, sensitivity analysis and additional scenarios indicate a wide range of solid biomass input (1.2-14.5mt).

\subsubsection{Biomass flows per scenario in 2030}

Figure 37 to Figure 40 show biomass consumption per feedstock, indicating their origin (domestic, regional, global), its supply to the end-use sectors of electricity, heat, fuels and chemicals, as well as the final output of bio-based energy and non-energy. It should be noted that in conversion technologies that produce multiple outputs, biomass input has been allocated on the basis of the energy content of the outputs they produce. Also, in order to include the non-energy sector, biomass consumption for chemicals is based on lower heating value of products (see Appendix 2). Note that for simplification purposes, biomass feedstocks in Figure 37 to Figure 40 are aggregated at a higher level compared to Section 4.1.5.2 as described in Appendix 2. 


\section{RegLowTech - 2030}

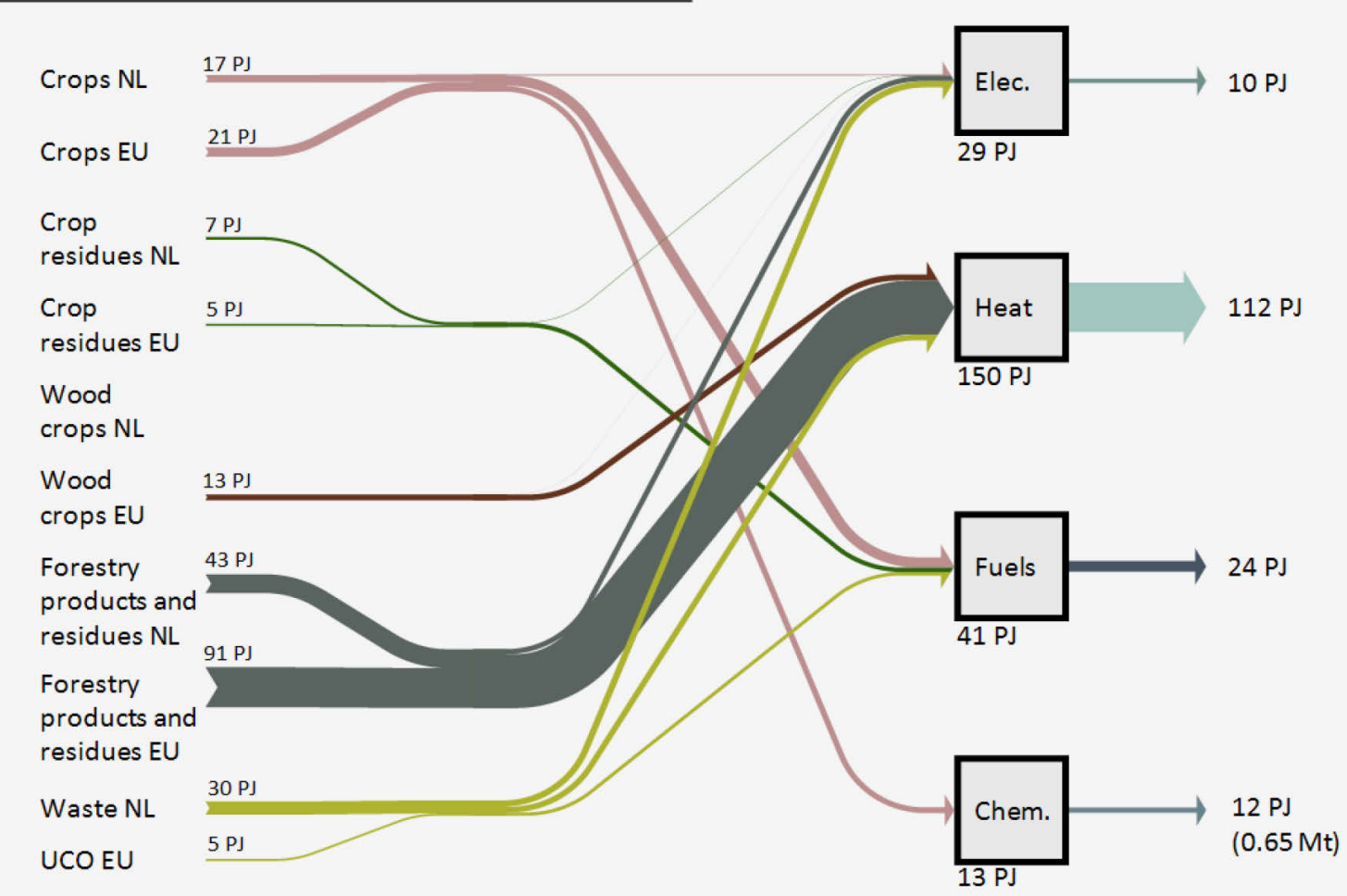

Figure 37 Biomass consumption and final bioenergy and non-energy production in the Dutch energy system in the Netherlands in RegLowTech in 2030

\section{GlobLowTech - 2030}

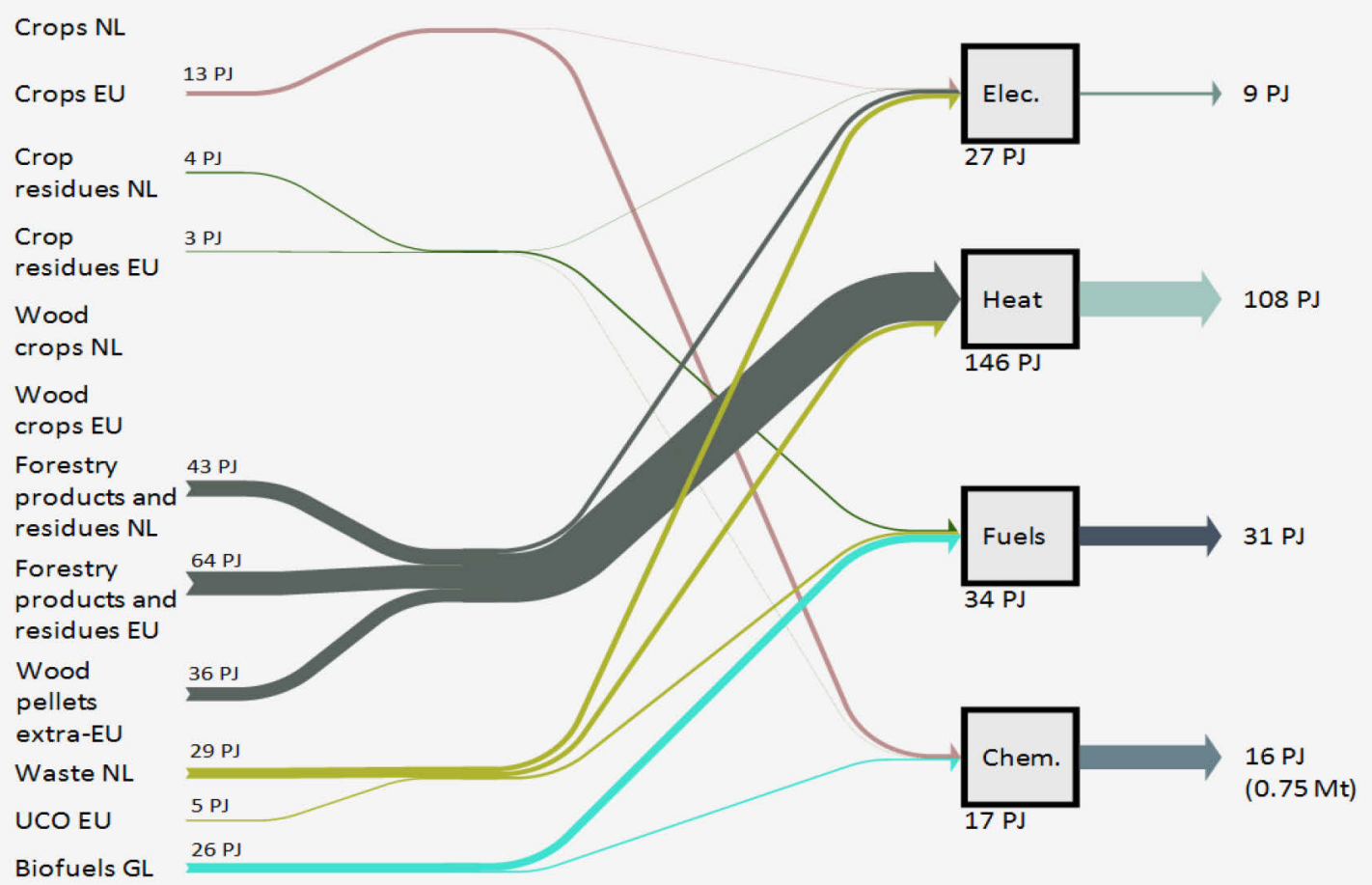

Figure 38 Biomass consumption and final bioenergy and non-energy production in the Dutch energy system in the Netherlands in GlobLowTech in 2030 


\section{RegHighTech - 2030}

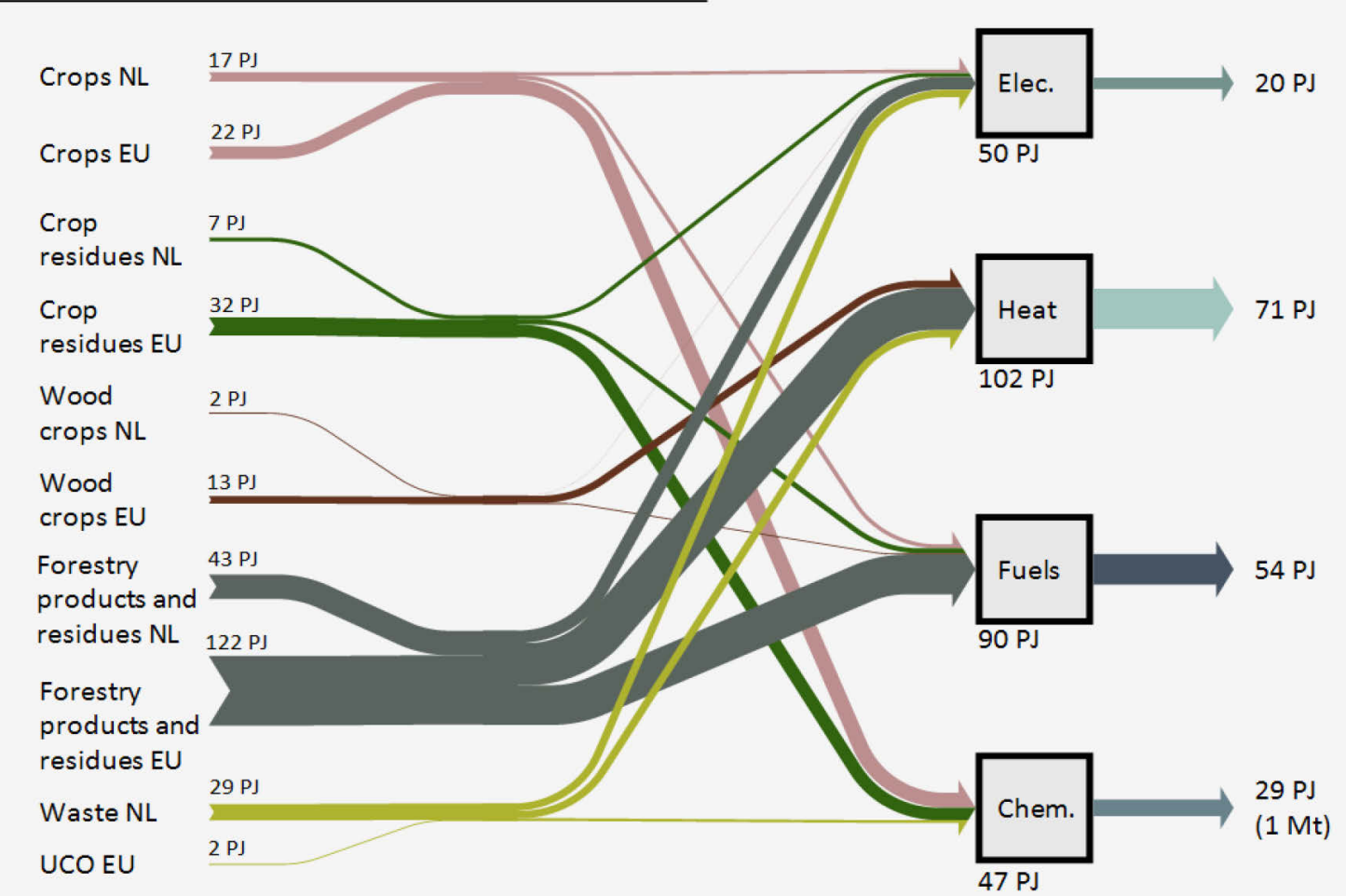

Figure 39 Biomass consumption and final bioenergy and non-energy production in the Dutch energy system in the Netherlands in RegHighTech in 2030

\section{GlobHighTech - 2030}

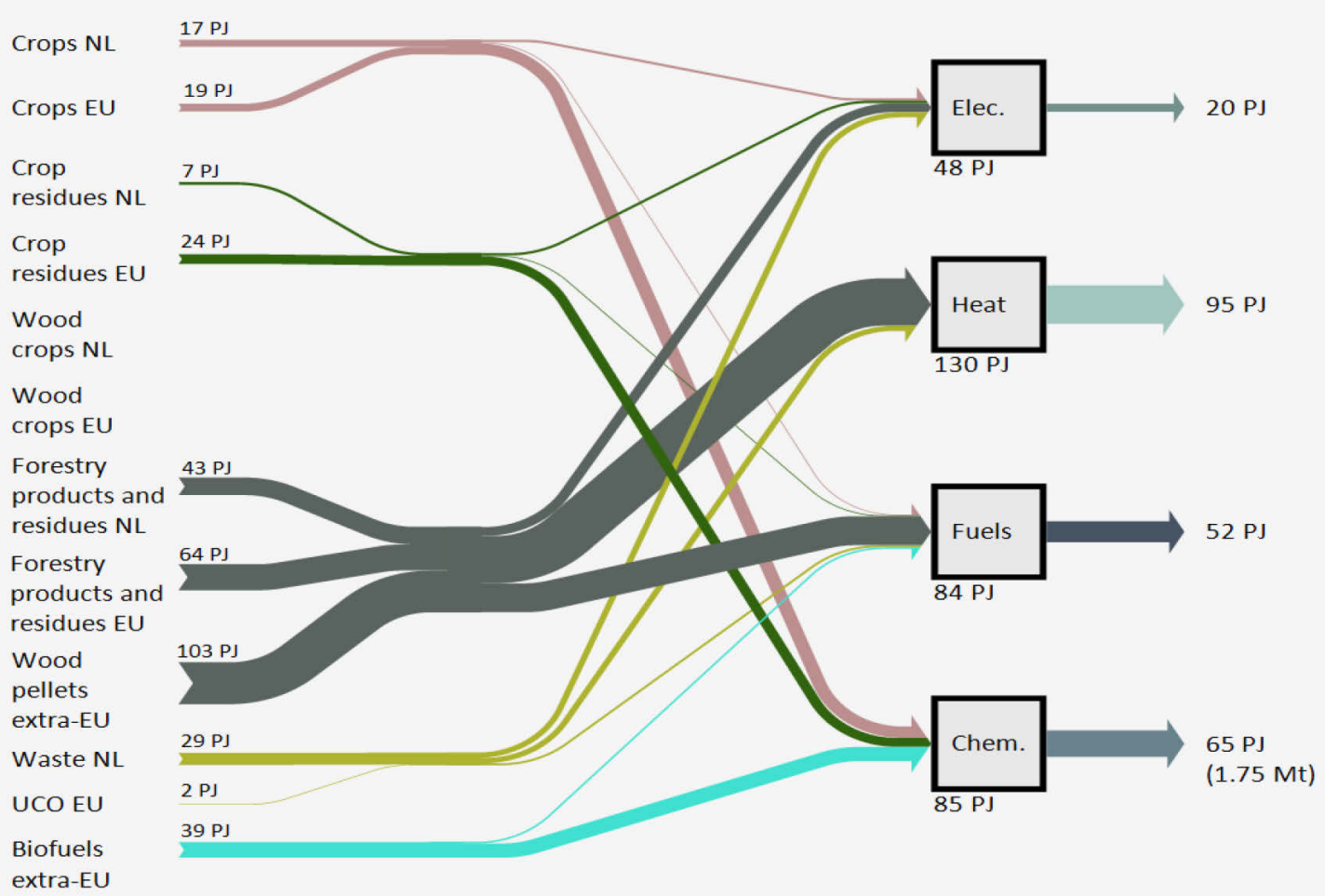

Figure 40 Biomass consumption and final bioenergy and non-energy production in the Dutch energy system in the Netherlands in GlobHighTech in 2030 
For 2030, the key points are:

- Heat is the largest sector both in primary demand for biomass and in final supply of energy especially in low technology development scenarios.

- The output of biofuel and biochemical sectors' contribution to primary demand and final supply increases from low to high technology development; in the regional scenario, biofuels are the second largest consuming and supplying sector, while in the global scenario biofuels and biochemicals are comparable.

- The largest consumed feedstock is forestry products and forestry residues, which in global scenarios compete with crop residues and wood crops compared to regional scenarios.

- In global scenarios the key imported feedstocks are wood pellets and ethanol, which are directed to heat and fuels in low technology development scenarios and to heat and chemicals in high technology development scenarios (comparison across the trade axis, within the same technology development assumptions).

\subsection{7 $\mathrm{CO}_{2}$ emissions}

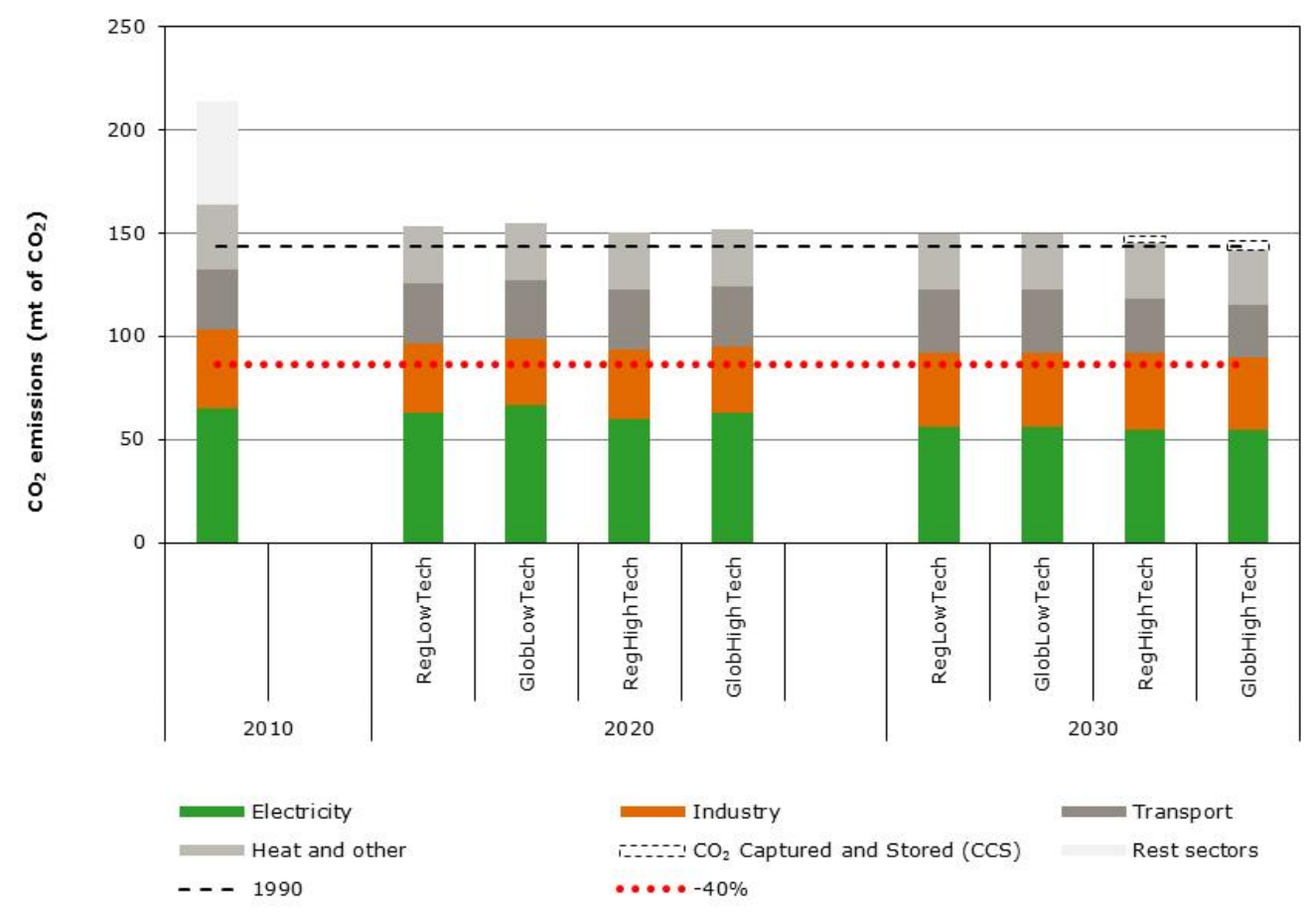

Figure 41 Direct $\mathrm{CO}_{2}$ emission in the Netherlands in 2010-2030

Direct emissions (Figure 41) refer to $\mathrm{CO}_{2}$ emissions from electricity production, industrial processes (process emissions; i.e. carbon in feedstock embedded in final products is not taken into account, nor it is affected by the $\mathrm{CO}_{2}$ emission tax), emissions from the production and consumption of road transport fuels (emissions from aviation not taken into account in this figure), heat production, and domestic biomass production and transport of biomass within the Netherlands. Emissions from biomass production and transport of biomass to the Netherlands that occur outside the country (in regional and global scenarios) are not included in domestic emissions and are addressed separately (Figure 42). 
It should be noted that sectoral representation is indicative when compared to national greenhouse gas emission inventories. ${ }^{18}$ The figure also presents the baseline emissions (1990) - the year from which relative emission reduction is expected and the $40 \%$ emission reduction target in 2030 compared to 1990 emissions (note that the target is applied only to emissions from sectors included in MARKAL-NL-UU). For completeness, we also present emissions from sectors not assessed by the model for 2010. (Rest sectors in Figure 41).

- In the presence of policies, total emissions from 2010 are reduced to levels comparable to 1990, but do not meet the EU's emission reduction target (-20\% emission reduction in 2020 compared to 1990 or approximately $115 \mathrm{mt}$ of $\mathrm{CO}_{2}$, for the sectors included in the model).

- Overall, the electricity and industry sector reduce their emissions by $4.5-10 \mathrm{mt}$ of $\mathrm{CO}_{2}$ by 2020 (compared to 2010) and by an additional $1-7 \mathrm{mt}$ of $\mathrm{CO}_{2}$ between 2020 and 2030, which in relative terms represents a 5-10\% reduction in 2020 and a $11-13 \%$ reduction in 2020 and 2030, compared to 2010 , respectively. This reduction is achieved partly by the gradual shift from coal to natural gas consumption and the output from renewable sources (electricity sector) and biomass heat utilization by industry. Emission reduction is steeper in high technology development scenarios early in the time horizon (2020) compared to reduction achieved between 2020 and 2030. Low technology development scenarios, on the other hand reach similar emission reduction levels in the periods 2010-2020 and 2020-2030.

- In 2020, emissions from the transport sector remain relatively stable compared to 2010. In 2030, low technology development scenarios show an increase of 6-8\% (compared to 2010), despite the blending of biofuels in the transport fuel mix, due to the increasing transport fuel demand. High technology development scenarios in 2030 show a decrease of $10-12 \%$, where FT fuels are supplied from gasification technologies.

- In high technology development scenarios, CCS is deployed and the amount of $\mathrm{CO}_{2}$ stored is approximately $2-4 \mathrm{mt}$; this is primarily bio-CCS from the gasification technologies.

- Finally, emissions from other heat (e.g. agriculture, residential) decrease primarily due to lower demand.

Figure 42 presents the indirect $\mathrm{CO}_{2}$ emissions from biomass utilization. These emissions are related to the production and transport of biomass from the sourcing regions to the Netherlands. In addition, the figure presents a range of indirect $\mathrm{CO}_{2}$ emissions from biomass utilization as found in extreme scenario runs (high and low fossil fuel prices, i.e. $\pm 50 \%$ from reference fossil fuel prices).

- Indirect $\mathrm{CO}_{2}$ emissions are in the order of $1-3 \mathrm{mt}$ of $\mathrm{CO}_{2}$ in 2020 and 1-4mt of $\mathrm{CO}_{2}$ in 2030. International trade scenarios consistently show higher indirect $\mathrm{CO}_{2}$ emissions by a factor of 2-3 and a wider range than their respective regional trade scenarios.

- From 2020 to 2030, indirect $\mathrm{CO}_{2}$ emissions increase in all scenarios by $20-60 \%$ as a consequence of larger biomass consumption. An exception is the GlobLowTech scenario, in which indirect $\mathrm{CO}_{2}$ emissions decrease by approximately $30 \%$. That is because in this scenario there is a partial switch from global biomass commodities in 2020 to EU resources in 2030, which results in overall lower emissions (see also Figure 32).

- Across the ranges provided, the most resilient (lowest variation) of all the scenarios are the regional trade scenarios, of which the low technology development shows the least variation. On the other hand, open trade scenarios under high technology development may lead to as much as $11.6 \mathrm{mt}$ of

\footnotetext{
${ }^{18}$ Model calibration was performed on energy consumption and installed capacities of technologies (measured variables), therefore emission estimates may vary. In addition, the reporting of emissions in the national registry may vary from the allocation applied in this study. The latter is particularly relevant for the industry and electricity sector, where electricity from co-generation can either be allocated to industry or to electricity in emission registries. In this study these are allocated to the electricity sector. Thirdly, all industrial heat demand in 2020 is assumed to be supplied by natural gas (except from co-generated heat supplied to agriculture, parts of industry, etc.). However, in reality other fuels such as oil, blast furnace gas, etc. (with higher emission factors than natural gas) are also used.
} 
$\mathrm{CO}_{2}$ emissions, which represents roughly $15 \%$ of the direct $\mathrm{CO}_{2}$ emission reduction achieved in the Netherlands under the same scenario assumptions compared to 2010 (see also Figure 70).

\section{Key message}

Under moderate tax on $\mathrm{CO}_{2}$ emissions, national $\mathrm{CO}_{2}$ emissions are expected to decline by 2030 to 2010 levels, but the emission reduction targeted by the EU is not achieved by any of the reference scenarios. There is slightly higher emission reduction potential in high technology development scenarios (by $5-8 \mathrm{mt}$ of $\mathrm{CO}_{2}$ ) compared to low technology development, which is partly realized by the deployment of CCS. Reduction is mainly achieved by the electricity and industry sectors. The utilization of regional and global biomass decreases emission reduction by $1-3 \%$. In extreme scenarios (with high fossil energy prices), indirect emissions may be significant (>10mt), which in relative terms reduces the emission reduction by $10-50 \%$.

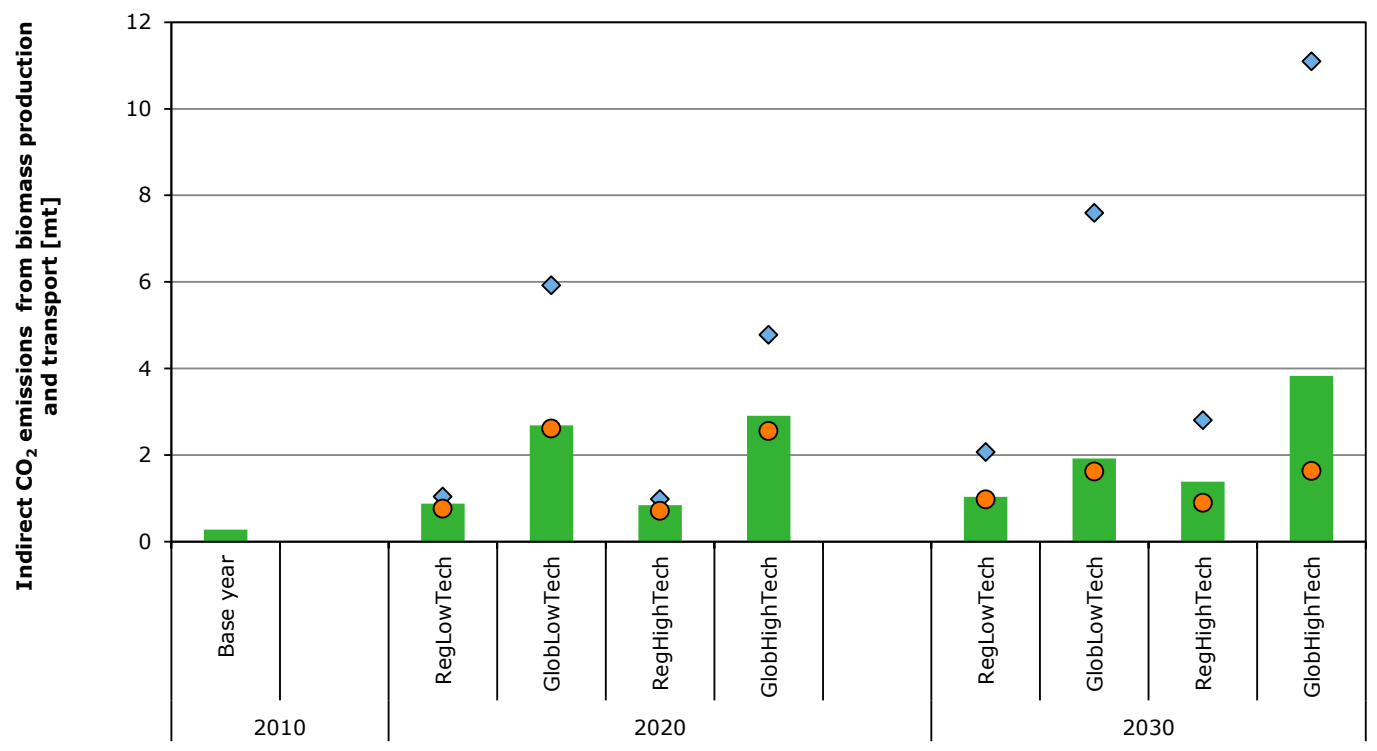

هiomass resources $\quad \diamond$ Biomass max (high fossil fuel price) oBiomass min (low fossil fuel price)

Figure 42 Indirect $\mathrm{CO}_{2}$ emissions from biomass production and transport in regions outside of the Netherlands in 2010-2030 ( $\mathrm{mt} \mathrm{CO}_{2}$ ).

Note: indirect $\mathrm{CO}_{2}$ emissions do not include indirect emissions from fossil resources.

\subsection{Top-down MAGNET projections}

The results are based on the global general equilibrium MAGNET model. A NoBioBased scenario was created as a counterfactual to calculate the contribution of the bioeconomy. In the NoBioBased scenario bioeconomy, developments in the transport, chemical and energy sectors are kept at their current levels. 


\subsubsection{GDP and sectoral value added (in $€$ billions)}

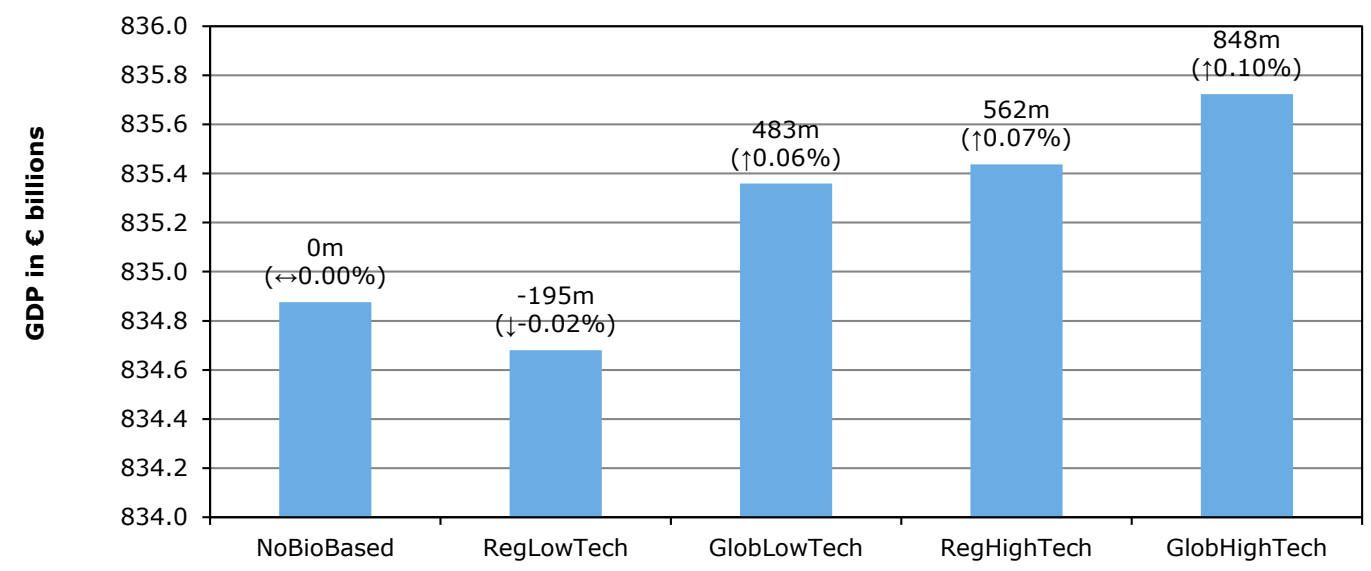

Figure 43 GDP in Netherlands (2030, € millions)

Figure 43 shows the GDP effect of the MEV II and the NoBioBased scenarios in the Netherlands in 2030. The GDP impacts are modest and both investing in technological change and sourcing globally add to GDP:

- High technology scenarios obtain a higher GDP value in 2030 relative to the low technology scenarios. The GlobHighTech scenario with high technological change and global open markets obtains the highest GDP value and the RegLowTech with low technological change and regional EU markets obtains the lowest GDP value in 2030. The GDP difference between these two scenarios is about $€ 1,050 \mathrm{~m}$ or $0.12 \%$ of Dutch GDP.

- The HighTech dimension adds $€ 350 \mathrm{~m}$ to GDP in the globalized world (difference between GlobHighTech and GlobLowTech) and about $€ 750 \mathrm{~m}$ in the regional EU market situation (difference between RegHighTech and RegLowTech). In the regional EU market scenarios, the GDP effect of high technical change is higher than in the global scenarios, as biomass is scarcer and more expensive in that scenario. Technological change solves a bigger problem.

- International or global scenarios also obtain a higher GDP level in 2030 than regional EU scenarios. The global dimension adds almost $€ 700 \mathrm{~m}$ to GDP in the LowTech situation (difference between GlobLowTech and RegLowTech) and almost $€ 300 \mathrm{~m}$ in the high tech situation (difference between GlobHighTech and RegHighTech). In the LowTech situation, the international dimension is more valuable than in the high tech situation, as importing cheap biomass is a way to make bio-based technologies more competitive. Especially imports of cheaper first-generation biofuels from South and North America are positive for GDP. In the regional scenarios, these imports are very restricted and biomass has to be sourced from within the EU. The GDP impact of restricting trade for biomass to be used in second-generation technologies is less significant due to the relatively large availability of EU biomass (residues, pellets). Opening up trade does not lead to cheaper imports, as biomass for second-generation processes in the EU is not scarce. 


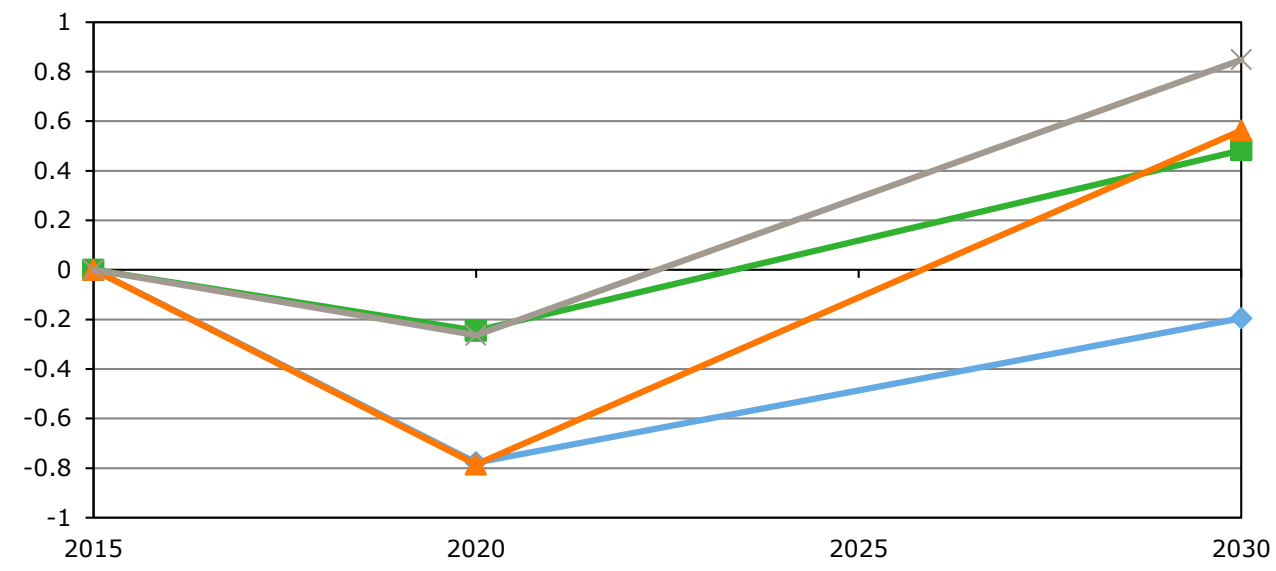

$\leadsto$ RegLowTech $=$ GlobLowTech $\quad$ RegHighTech $\leadsto$ GlobHighTech

Figure 44 Annual effect of implementation of a bio-based economy on GDP for MEV II scenarios compared with a NoBioBased scenario (b/n €).

Figure 44 shows the GDP effect of the MEV II scenarios relative to the NoBioBased scenario in the Netherlands in the period 2015-2030. Untill 2020 the Renewable Energy Directive effect dominates and has a negative impact on GDP. In the 2020-2030 period technological progress gets more eminent and has a positive contribution to GDP.

- In the short term, complying to the renewable energy targets leads to negative GDP effects in all scenarios in 2020 compared to a NoBioBased scenario as bioenergy technologies are not competitive with their fossil substitutes. The negative effect is stronger in the regional scenarios ( $€ 0.8 \mathrm{bn}$ ) than in the global scenarios (-€0.2bn) as the EU cannot import (relatively cheap) biofuels from South and North America.

- In the 2020-2030 period the positive effect of technology advances becomes visible and is larger for HighTech ( $€ 1-1.4 \mathrm{bn}$ annually) than LowTech ( $€ 0.6 \mathrm{bn}$ annually) scenarios. High, often biomass saving, technological change has a higher contribution in the regional market case $(€ 1.4 \mathrm{bn})$ than in the global markets case $(€ 1.0 \mathrm{bn})$ as biomass is more scarce and therefore more expensive in this case.

- Figure 44 shows that although the GlobLowtech and RegHighTech scenario lead to the same results in terms of GDP in 2030 the drivers are different. In the GlobLowTech scenario the negative GDP impact is limited in 2020 as RED is globally sourced. However as technology development is limited the increase in GDP in 2020-2030 is modest. In the RegHighTech scenario the impact on GDP is very negative in 2020 due to the restriction on biofuel imports from outside EU, but given the scarcity of biomass the contribution of technological change is very high.

Across all scenarios only RegLowTech still has a negative GDP effect of $€ 200 \mathrm{~m}$ in 2030 . Open markets and investments in technology development lead to a positive GDP effect of $€ 800 \mathrm{~m}$ annually in 2030 (GlobHighTech scenario).

\section{Key message}

Untill 2020 the Renewable Energy Directive effect dominates and has a negative impact on GDP. In the 2020-2030 periode technological progress gets more eminent and has a positive contribution to GDP. The GDP effects can be positive or negative compared to a NoBioBased scenario. The negative impact occurs in the RegLowTech scenario where bio-based technologies are largely not competitive due to more expensive feedstocks and less efficient bio-based technologies, and are used only because their use is dictated by renewable energy policies. Relative to the negative GDP effect in the RegLowTech scenario, opening up markets or investing in tech change induces both a positive GDP 
effect in such a way that the overall GDP effect becomes positive. Combining high technical change and open markets leads to a positive and the largest GDP effect.

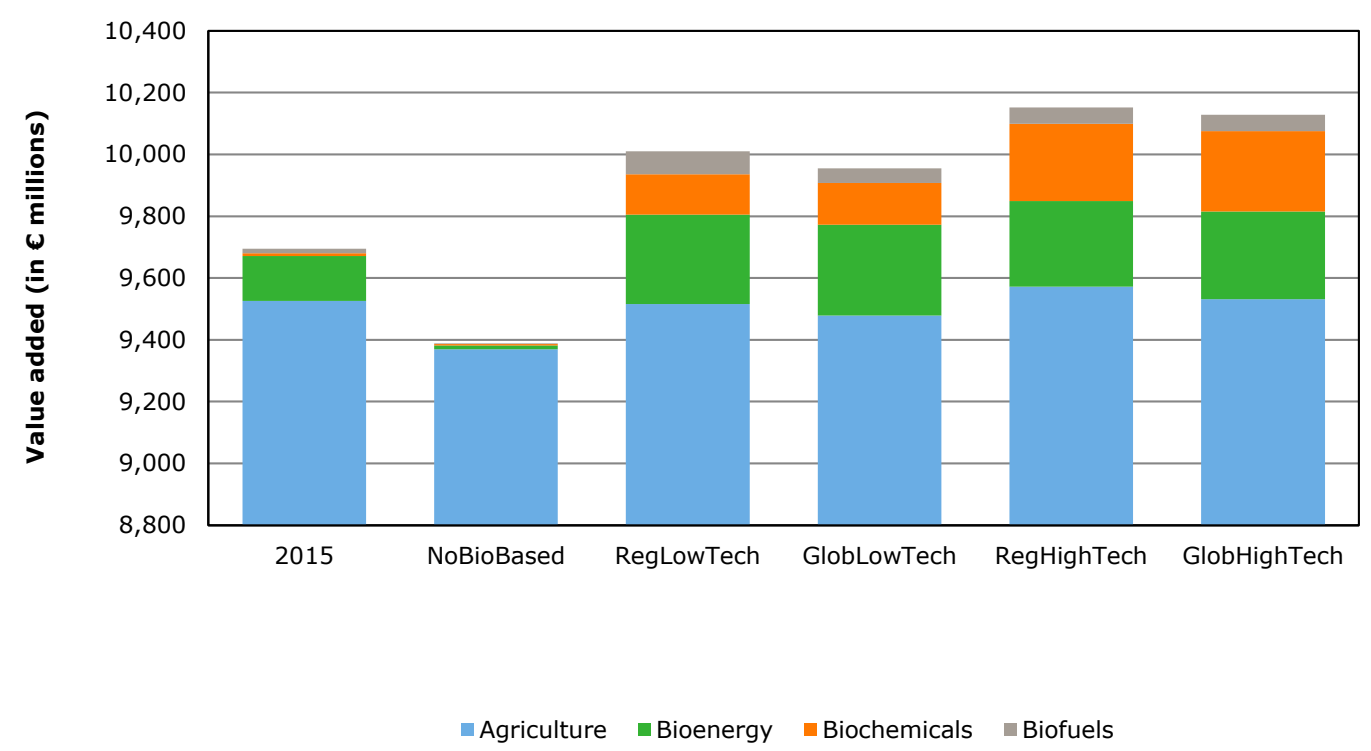

Figure 45 Value added for 2030 in different MEVII scenarios and reference (NoBioBased) in comparison with 2015.

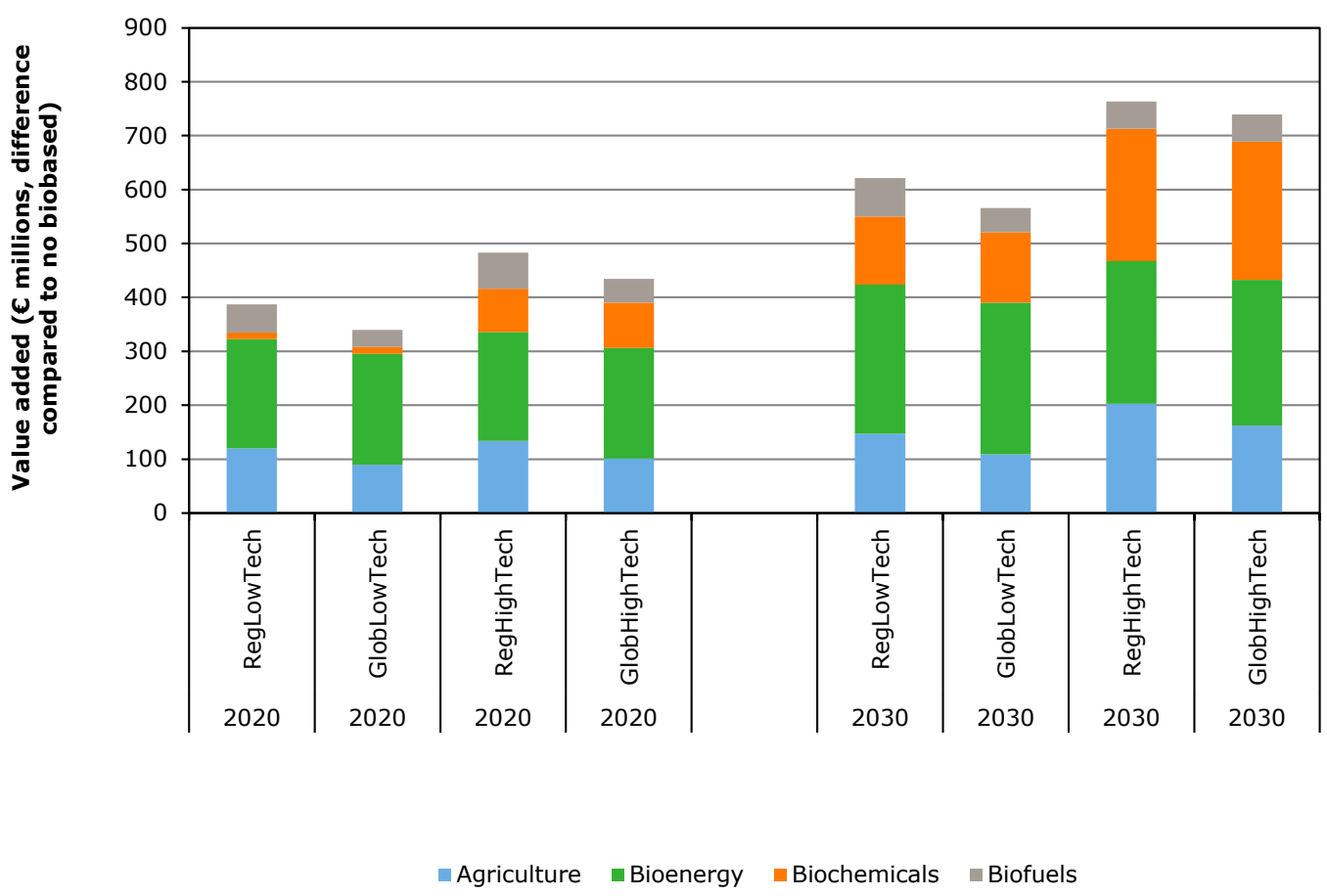

Figure 46 Value added of bioeconomy sectors ( $€$ millions) in MEVII scenarios relative to NoBioBased scenario in 2020 and 2030. 
- Figure $45^{19}$ shows the value added of various bioeconomy sectors in the MEV II and the NoBioBased scenarios in the Netherlands in 2015 and 2030. Figure 45 illustrates these results relative to the NoBioBased scenario to show the contribution of the emergence of the bioeconomy. The emergence of the bioeconomy has a positive impact on value added of all bioeconomy sectors. Within the bioeconomy, agriculture is a key sector in terms of value added. Value added decreases slightly ( $€ 160 \mathrm{~m}$ ) between 2015 and 2030 in the NoBioBased scenarios. In all four MEV II scenarios, value added in the Netherlands increases due to the emergence of a broader bioeconomy. The increase in value added relative to the NoBioBased is higher in the HighTech scenarios ( $€ 200 \mathrm{~m})$ than in the LowTech scenarios ( $€ 120 \mathrm{~m})$ in 2030 . The opening up of trade has a very minor negative impact ( $€ 40 \mathrm{~m})$ on Dutch agricultural value added in 2030 .

- The impact of biomass use on the agricultural sectors is limited as most of the biomass will be imported from the EU. Value added in agriculture increases a bit more in the HighTech scenarios compared to the LowTech scenarios, as the demand-creating impact of tech change dominates the cost saving impact. Higher biomass conversion rates in especially bio-based chemicals lead to less biomass input per unit of output, but also to lower prices and therefore higher demand. The demand-creating effect dominates the biomass saving effect per unit of output in the simulations.

- Value added in bioenergy is rather stable in the four scenarios and is driven by the renewable energy directive. Relative to the NoBioBased scenario, the value added is about $€ 200 \mathrm{~m}$ in 2020 and $€ 280 \mathrm{~m}$ in 2030 . It is slightly higher in the LowTech scenarios (by $€ 10 \mathrm{~m}$ ) than in the HighTech scenarios in 2030.

- Value added in biochemical or bulk bio-based polymers grows faster in the HighTech scenarios due to high technological change. The latter induces the substitution of fossil inputs by bio-based inputs and it stimulates demand for chemical products. In the HighTech scenarios, the value added in the biochemical sector increases by $€ 80 \mathrm{~m}$ in 2020 and $€ 250 \mathrm{~m}$ in 2030 while the value is about $€ 12 \mathrm{~m}$ in 2020 and $€ 130 \mathrm{~m}$ in 2030 in the LowTech scenarios. The additional value added reflects new bulk bio-based polymers and not all other bio-based chemical products, which had a value of $€ 740 \mathrm{~m}$ in 2013 (see Sections 2.2 and 3.4.2).

- Biofuel value added is modest ( $€ 50 \mathrm{~m})$ and more or less the same among the scenarios. In the regional LowTech scenario, it is slightly higher $(€ 75 \mathrm{~m})$.

- The bioeconomy is the largest in HighTech scenarios, driven by the developments in agriculture, bioenergy and the bio-based chemical sector. The increase in value added of the selected bioeconomy sectors relative to the NoBioBased scenario is higher in the HighTech than the LowTech scenarios by, respectively, about $€ 740-760 \mathrm{~m}$ and $€ 560-620 \mathrm{~m}$.

\section{Key message}

The involvement of the bioeconomy has a positive impact on the value added of the Dutch bioeconomy. Relative to the NoBioBased scenario, the bioeconomy sector contributes almost $€ 600 \mathrm{~m}$ with low technical change and almost $€ 800 \mathrm{~m}$ with high technological change. Biofuels and bioenergy are largely driven by policies and value added is fairly constant across the scenarios. For agriculture and especially biochemical, the HighTech scenarios create higher value added.

\footnotetext{
${ }^{19}$ The food processing, forestry, and pulp \& paper sectors are not included.
} 


\subsubsection{Employment}

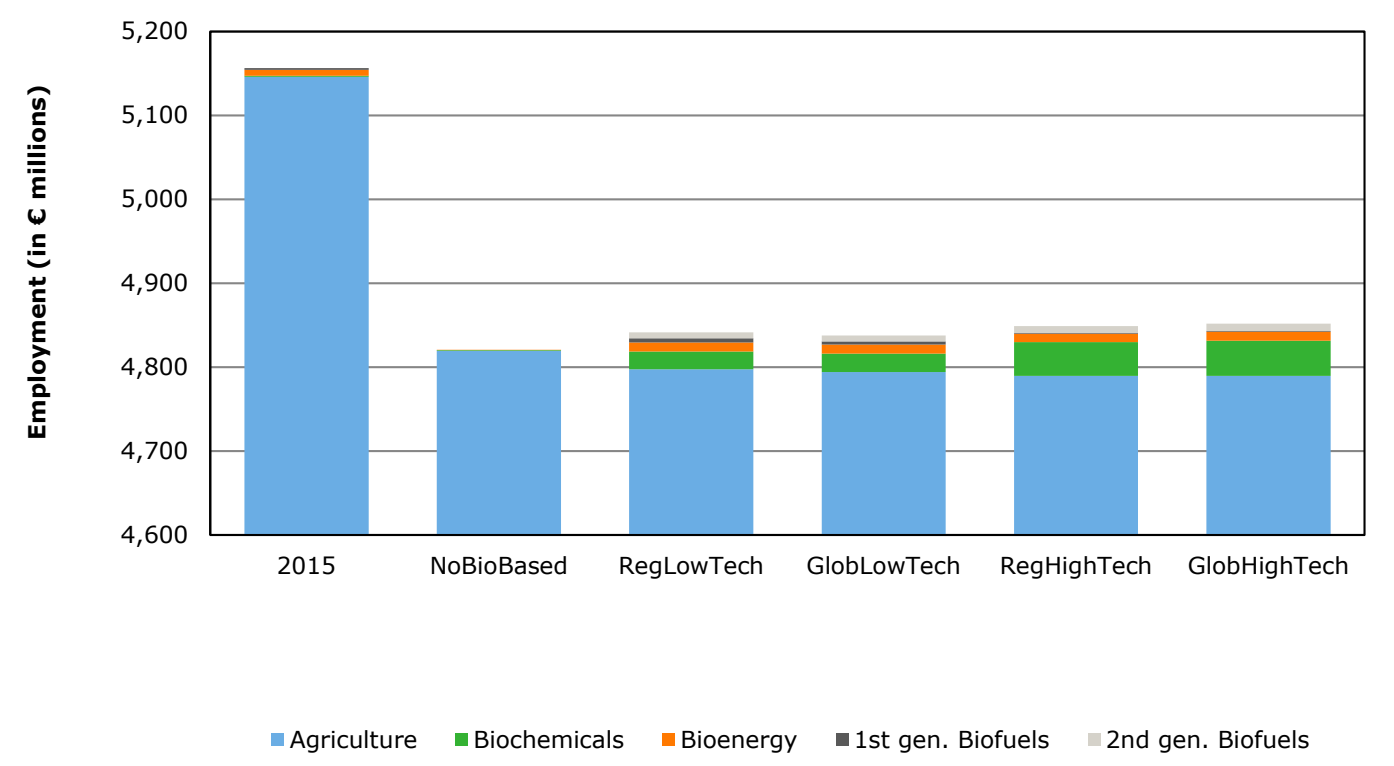

Figure 47 Employment (in $€$ millions) of bioeconomy sectors in the Netherlands in 2030 under different scenarios compared to 2015

- Figure 47 shows the impact on employment in 2015 and 2030. The impact of the MEV II scenarios on employment is modest. Jobs are created only in biochemical. Employment in the bioeconomy is lower in 2030 than in 2015 due to the decline of employment in agriculture. This is a long-term trend that is mainly driven by relatively high increases in labour productivity and low growth in food demand (inelastic demand).

- The bioeconomy can mitigate this effect only modestly. It is important to realize that we assume full employment in the long run and jobs created in the bioeconomy sectors have to be taken from other sectors.

- The highest employment impact is due to bio-based chemicals (bulk bio-based polymers) in the HighTech scenarios and to a smaller extent in the global LowTech scenario. The additional employment reflects employment in new bulk bio-based polymers and not employment in all other bio-based chemical products (see Sections 2.2 and 3.4.2).

- Biofuel jobs in the LowTech scenario are linked to first-generation biofuels and in the HighTech scenarios they are linked to second-generation biofuels.

\section{Key message}

The impact of the MEV II scenarios on employment is modest. Most jobs are created in the biochemical sector. 


\subsubsection{Biomass use in transport, electricity and chemical sectors}

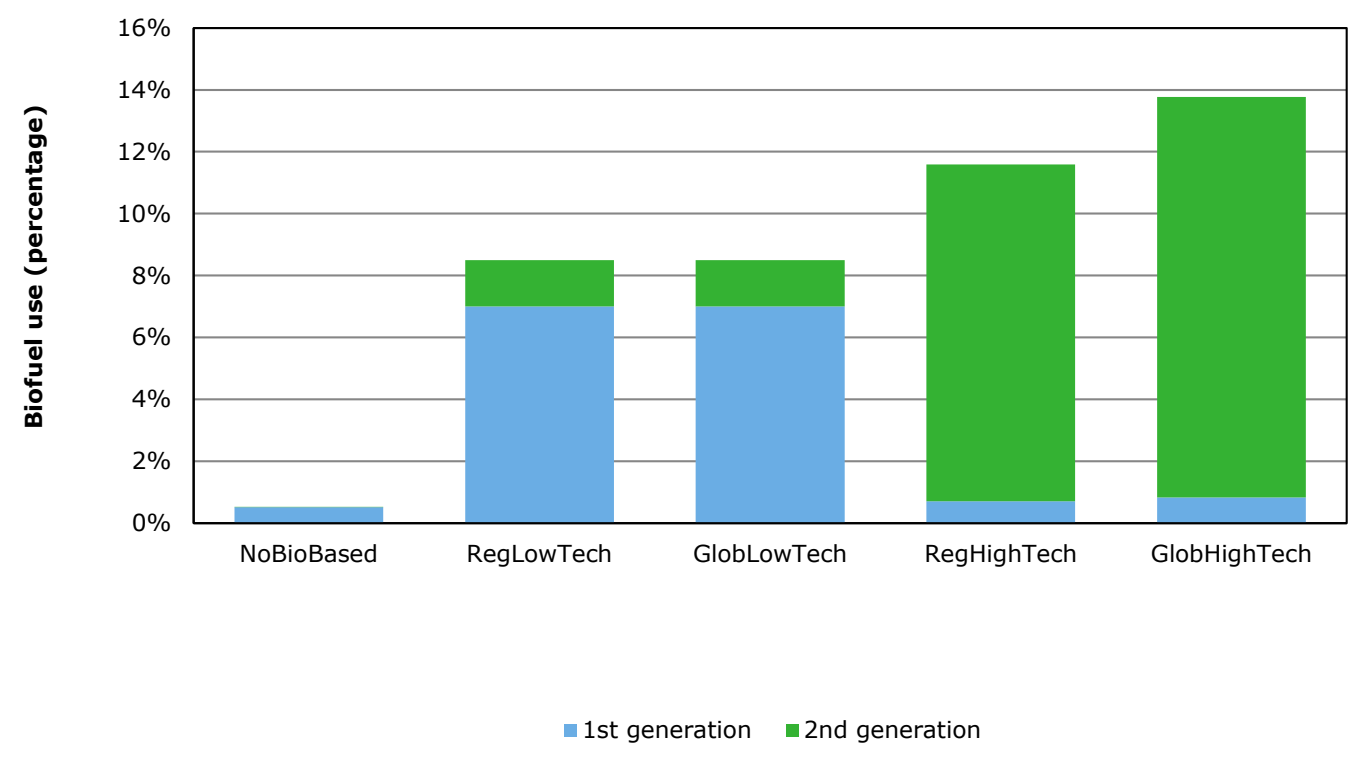

Figure 48 First- and second-generation biofuel shares in 2030

- Figure 48 shows the impact on first- and second-generation biofuel shares in 2030. In the LowTech scenarios, mandates are binding and filled with first-generation biofuels, while in the HighTech scenarios the shares increase above the mandate and are filled with second-generation biofuels. In the LowTech scenarios, the biofuel shares are equal to the EU biofuel mandate. This implies that $7 \%$ first-generation biofuels and $1.5 \%$ second-generation biofuels are obtained. The latter counts double and the total adds up to $10 \%$ blending mandate in 2020 and 2030 as we assume in these scenarios that the mandate will be maintained until 2030.

- In the HighTech scenarios, biofuels become competitive and the biofuel shares exceed the $10 \%$ mandate. Due to high technological change, second-generation biofuels are the main source.

- A comparison of the regional versus global dimension shows:

- In the LowTech scenarios, the global dimension is not important, as the biofuel shares are determined by the mandate.

In the HighTech scenarios, the global scenario leads to a higher blending rate than is required in the mandate. The biofuel share increases from $13.8 \%$ in the global scenario to $11.5 \%$ in the regional scenario. Cheaper biomass prices sourced from all over the world are the most important driver behind this result.

\section{Key message}

The biofuel mandate determines the biofuel share in fossil fuels in the LowTech scenarios. In the HighTech scenarios, biofuels become competitive and their share increases to $11.5 \%$ in the regional scenario and, due to cheaper feedstock prices, to almost $14 \%$ in the global scenario. 


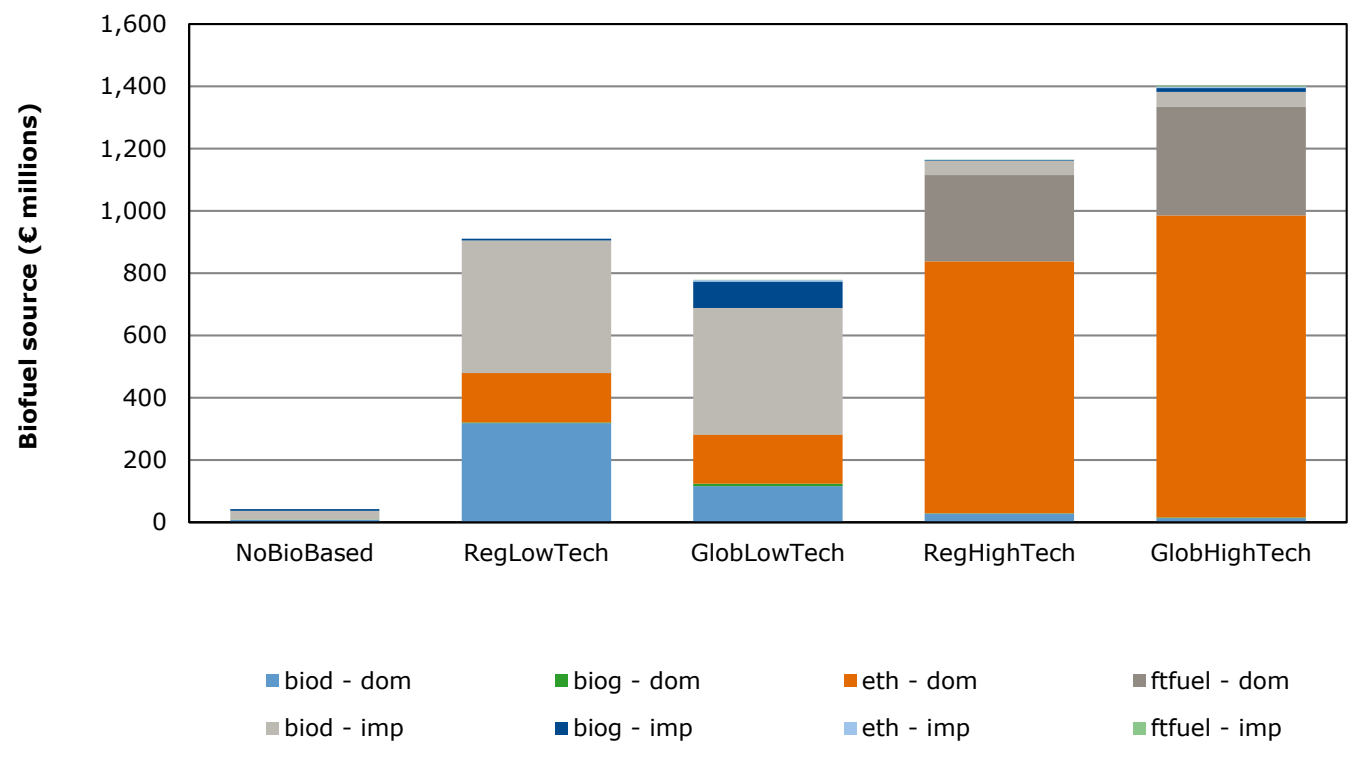

Figure 49 Biofuel composition by type and origin (2030, $€$ millions)

Biod $=$ biodiesel, biog $=$ biogasoline, eth $=$ cellulosic-based ethanol, ftfuel $=$ FT fuel

Dom $=$ domestic and $i m p=$ imported

Figure 49 shows the biofuel composition in the Dutch economy in $€$ millions in 2030. In the low technology scenarios, biofuels are mainly sourced from domestic and European biodiesel, and in the HighTech scenarios the total amount of biomass used is higher and mainly sourced from domestically produced ethanol.

- In LowTech scenarios, first-generation biofuels play an important role and are mostly imported. In addition to imported biodiesel, domestically produced biodiesel is important in the regional scenario. Biogasoline imports appear only in the global scenario as they are mainly imported from North and South America and these imports are not allowed in the regional scenario.

- The value of biofuels is higher in the regional LowTech scenario than in the global LowTech scenario, as in the regional scenario relatively efficient and cheap biogasoline imports are blocked.

- The value of biofuels is higher in high technology scenarios as the biofuel shares are higher than in the LowTech scenarios.

In HighTech scenarios, second-generation biofuels (cellulosic-based ethanol (eth), and FT fuels (ftfuel)) are used that are mainly produced domestically. Second-generation biofuels are produced domestically from both domestic and imported biomass.

\section{Key message}

Biofuels are mainly sourced from domestic and European biodiesel in the regional LowTech scenario. In the global LowTech scenario, cheaper biogasoline from the Americas is substituted for more expensive domestic sources. Cellulosic-based ethanol, which is produced domestically, is the key source in the HighTech scenarios. 


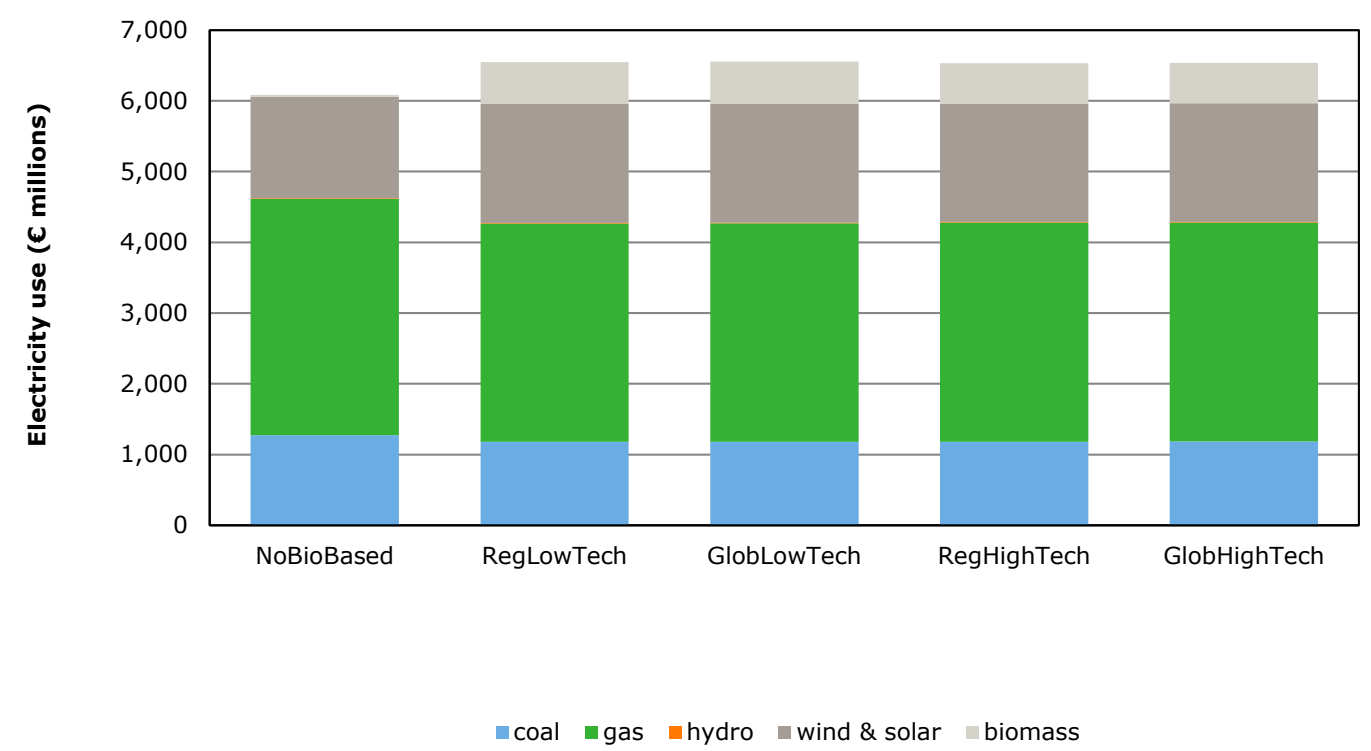

Figure 50 Electricity production by source in the Netherlands (2030)

- Figure 50 shows the electricity production by source in 2030 . The energy mix is fairly constant across the scenarios. Electricity levels do not differ very much among the MEV II scenarios. Technological change directly related to electricity production does not vary between energy technologies in the four scenarios.

- Coal and gas remain the main sources for electricity generation (75\% in the NoBioBased scenario and $65 \%$ in the MEV II scenarios).

- Electricity from wind \& solar is determined by the Dutch energy agreement and is stable across all four scenarios.

- Bioelectricity is about $9 \%$ in all scenarios. The share is slightly lower in the high technology scenarios as more biomass is used for other applications (e.g. second-generation biofuels). In the global scenarios, electricity production from biomass is slightly higher than in regional scenarios as pellets are allowed to be imported from all over the world.

\section{Key message}

The energy mix is stable across the MEV II scenarios. The biomass share is around $9 \%$ and is driven by the renewable energy directive. 


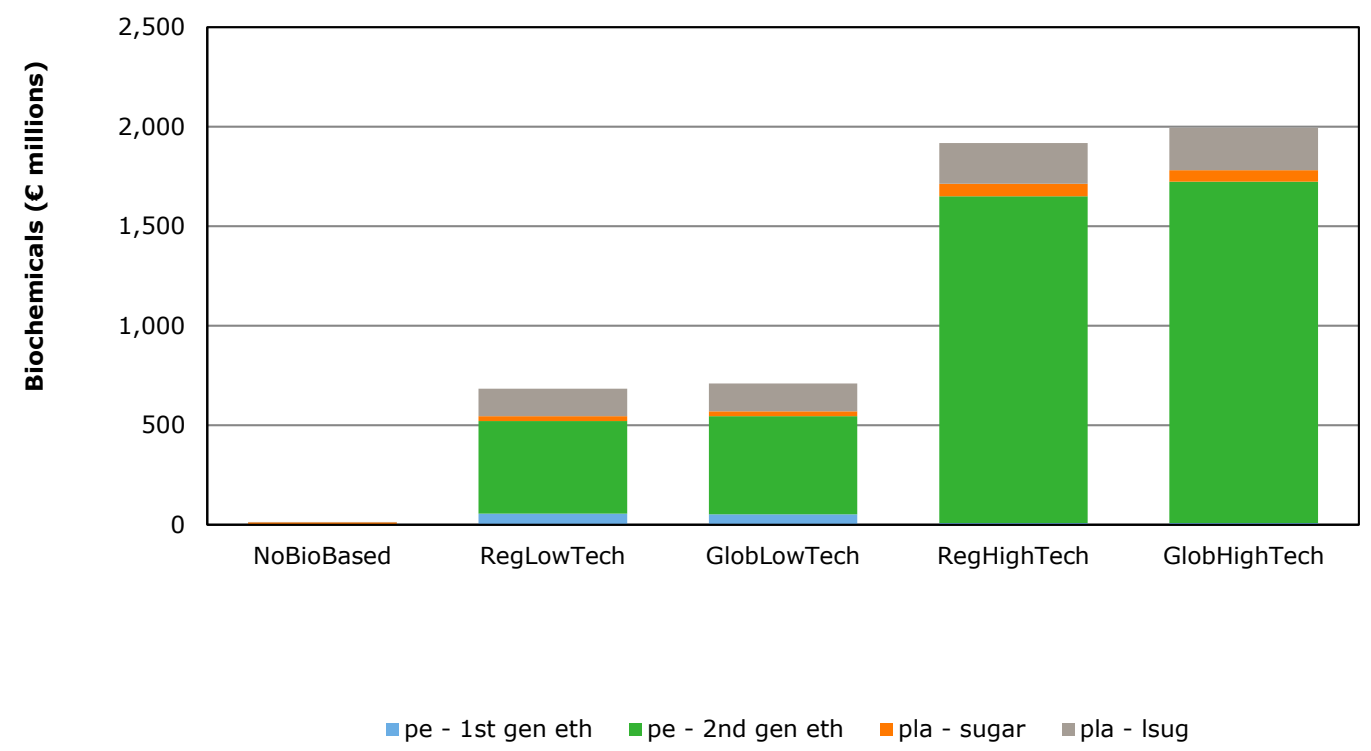

Figure 51 Production of bio-based chemicals (2030, $€$ millions)

- Figure 51 shows the production of bio-based chemicals and particularly new bulk bio-based polymers in 2030. These bio-based chemicals occur in all scenarios and are highest in the high technology scenarios. Technological change is key for biochemical developments. The expected high learning and/or technological change effects lead to a strong increase in the use of bio-based chemicals especially in the high technology scenarios. The value of bio-based chemicals is about $€ 2 b n$ in the high technology scenarios and $€ 700 \mathrm{~m}$ in the low technology scenarios.

- Key products are polyethylene (PE) from second-generation ethanol, PLA from lignocellulosic sugar and PLA from conventional sugar.

- PE obtains the highest value of $€ 600 \mathrm{~m}$ in the LowTech scenarios and $€ 1700 \mathrm{~m}$ in the HighTech scenarios. PLA appears sourced from both conventional sugar and lignocellulosic sugar, respectively $€ 60 \mathrm{~m}$ and $€ 200 \mathrm{~m}$ in the HighTech scenarios.

- The international dimension plays a more modest role as biomass for second-generation technologies is available within Europe at reasonable prices according to the bottom-up analyses. The international dimension creates an additional $€ 30 \mathrm{~m}$ and $€ 80 \mathrm{~m}$ in the low and high technology scenarios, respectively.

- Without tech change, both the production and the use of bio-based chemicals are limited. 


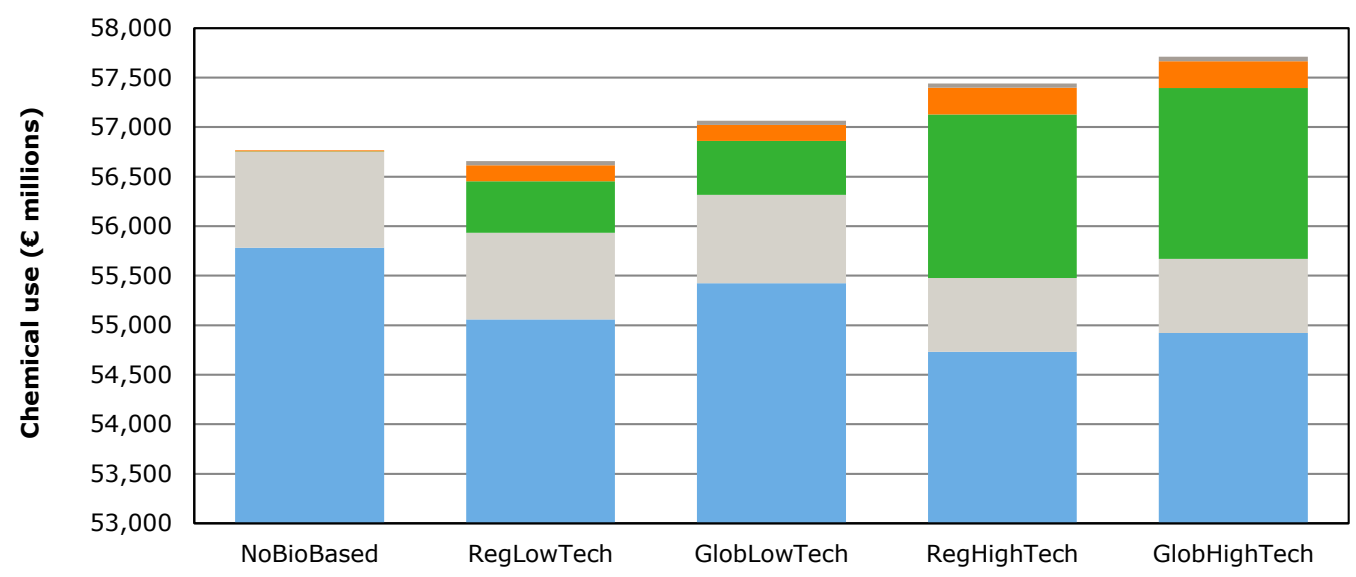

mother fossil chem $\square$ fchem $\square$ pe $\square$ pla $\square$ Isug

Figure 52 Production of chemicals (2030, $€$ millions), fchem and other fossil chem are both fossil based chemical sectors

Figure 52 shows the production of chemicals (bulk bio-based polymers) in 2030. Bio-based chemicals can reduce the projected decline of chemicals and reduce their fossil-based content.

- Chemicals decline by about $10 \%$ in the baseline scenario.

- Bulk bio-based polymers can reduce this decline by more than $1 \%$ in the low technology scenarios and by almost $4 \%$ in the high technology scenarios.

- In the high technology scenarios, the total bio-based share becomes about $9 \%$ given the base share of almost $5 \%$ of all other bio-based chemicals in 2013 (see Table 7).

- In the LowTech scenarios, $60 \%$ of the bulk bio-based polymers are substituted for fossil-based chemical production. $40 \%$ of production is due to new demand creation for chemicals. In the global high technology scenario, production growth is due to $50 \%$ fossil-based chemical substitution and $50 \%$ due to demand creation.

- The global dimension and the availability of cheaper feedstock lead to slightly higher bio-based chemical production in the Netherlands.

\section{Key message}

The developments of bulk bio-based polymers is very dependent on the level of technical change. In the HighTech scenarios, a value of $€ 2 \mathrm{bn}$ is created by producing polyethylene and PLA. These biochemicals moderate the decline of the chemical sector in the Netherlands by as much as $4 \%$. The share of total bio-based chemicals becomes $9 \%$ in the global HighTech scenario as all other bio-based chemicals add to a share of about $5 \%$ in total chemicals in 2013. In the HighTech scenarios, modern biochemical production growth is driven equally by demand creation and fossil-based chemical substitution. 


\subsubsection{Biomass supply}

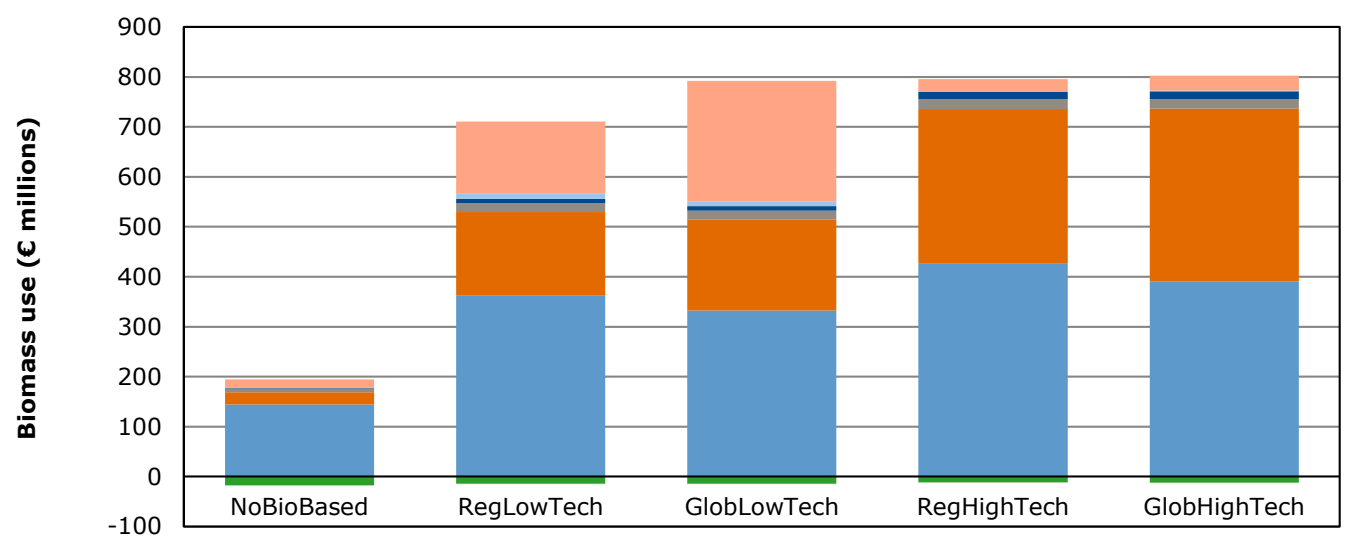

$\begin{array}{lll}\text { residue - Dom } & \text { residue - Exp } & \text { residue - Imp } \\ \text { mplantation - Dom } & \text { plantation - Exp } & \text { vplantation - Imp } \\ \square \text { primary - Dom } & \text { primary - Exp } & \text { primary - Imp }\end{array}$

Figure 53 Biomass consumption per feedstock by the transport, electricity and chemical sectors (2030, € millions)

Dom $=$ domestic, Exp = exported, Imp = imported

- Figure 53 shows biomass consumption per feedstock by the transport, electricity and chemical sectors. Biomass consumption increases 4 times relative to a NoBioBased economy. Relative to the NoBioBased scenario, the consumption of feedstock by the transport, electricity and chemical sectors is four times higher in the MEV II scenarios. In the national low technology scenario, the increase is a little lower (3.5 times higher).

- Biomass use in the HighTech scenarios is not much higher than in the global low technology scenario, as most demand comes from heat and renewable energy policies in electricity and fuel sectors, which is rather constant across the various scenarios. The additional demand from the chemical sector is partly compensated for by more efficient use of biomass due to better conversion rates (less biomass demand per unit of output).

- In the LowTech scenario. domestic and imported residues are important in addition to imports of primary agricultural products.

- First-generation feedstocks (sugar, oilseeds, cereals) play a minor role and are relatively more important in the LowTech scenario. In the regional scenario, they are sourced from within the EU. In the global low technology scenario, primary imports are much more important. The additional primary imports in the global scenario are mostly sugar from North and South America.

- In the HighTech scenarios, second-generation technologies are more competitive, and domestic and imported residues (e.g. pellets) are the main biomass source. Primary imports disappear as the second-generation technologies displace the first-generation technologies.

\section{Key message}

The use of biomass quadruples due to the emerging bioeconomy. In the LowTech scenarios, this is mainly sourced by foreign and domestic residues and imported primary products from within the EU. In the global high technology scenario, sugar imports from the Americas are also important. In the high technology scenarios, second-generation technologies are more competitive, and domestic and imported residues (e.g. pellets) are the main biomass source. 


\subsubsection{Trade balance}

In general terms, trade means the purchase and sale of commodities. In international trade, purchase and sale are replaced by imports and exports. A country's balance of trade is simply the difference between the value of its exports and the value of its imports during the course of a year. If the value of its exports over a certain period exceeds the value of its imports, it is called a trade surplus; conversely, if the value of total imports exceeds the value of total exports over a certain period, it is called a trade deficit (or, informally, trade gap).
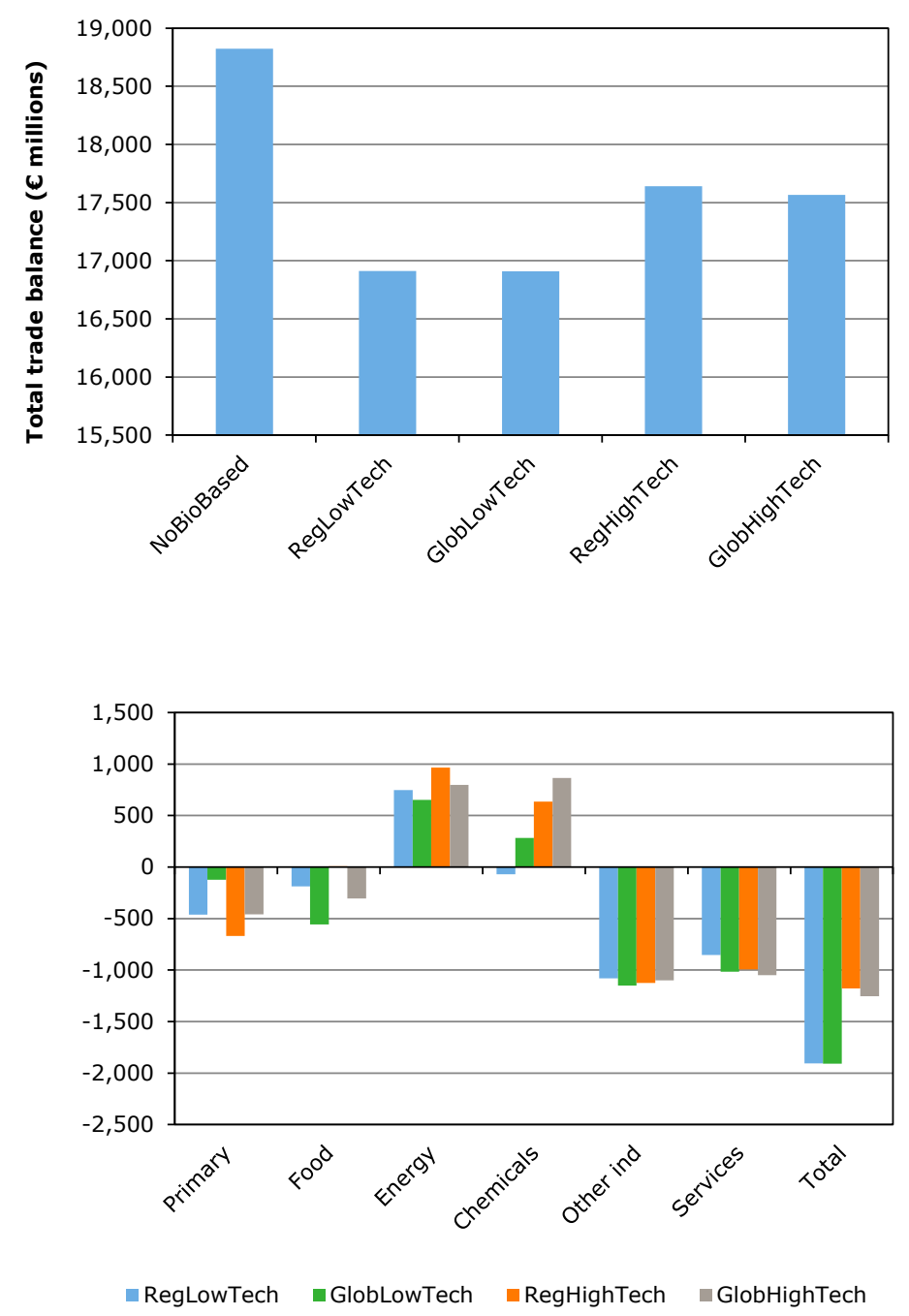

Figure 54 Trade balance for total economy (2030, € millions, upper figure) and trade balance difference relative to NoBioBased scenario (2030, € millions, lower figure).

Figure 54 shows that the total trade balance in the Netherlands deteriorates in the bioeconomy scenarios relative to the NoBioBased scenario. The energy and the chemical trade balance improve, but the deterioration in biomass-related sectors and other sectors in the economy dominates the overall effect.

- Relative to the NoBioBased scenario the trade surplus of the Netherlands decreases by about $€ 1$.5bn in the four MEV II scenarios.

- The right-hand side of Figure 52 shows that the trade balance for biomass imports (agriculture, forestry and pellets (primary) and processed food products (food)) is, as expected, negative due to the import of biomass to meet the biofuel and renewable energy targets.

- The trade balance for energy is, also as expected, positive as less fossil fuel has to be imported. As bioenergy developments are policy driven, the level of trade balance is similar across the scenarios as policies are similar between scenarios. 
- The trade balance of chemicals improves and especially with open markets and HighTech change the trade balance improves significantly.

- The biomass-related and energy/chemical-related trade balances together improve as biomass is turned into higher value added products and then exported. This effect is greater in the HighTech scenarios.

- However, the total trade balance effect is negative relative to the NoBioBased scenario and this is caused by a deterioration of the trade balance in 'other industries' and services. These sectors are very large and small changes create high value effects. The negative trade balance effect in these sectors is caused by a slightly higher wage and capital rate of return level in the MEV II scenarios relative to the NoBioBased scenario, as sources are triggered into the bioeconomy sectors. The latter causes an additional demand for production factors and leads to small increases in production factor prices. As part of the resources go to inefficient technologies, the overall effect on trade balance is negative.

- With tech change, the negative impact becomes lower. The reduction of trade surplus is about $€ 1$.2bn in the HighTech scenarios and about $€ 2 b n$ in the LowTech scenarios. The right-hand side of the figure above and the section below show that higher chemical exports in the HighTech scenario play an important role.

- In the MEV I there was a positive trade balance effect of introducing the bioeconomy, as the biobased technologies were assumed to be more competitive with their fossil substitutes in 2030. Also the share of bio-based chemicals was assumed to be $19 \%$ in MEV I, instead of the 4-5\% in MEV II. If the bio-based share is three times higher, then the positive contribution in the chemicals sector is also much higher. If we assume a factor of 2 to 3 times higher, we immediately again obtain the positive trade balance effect of introducing a bioeconomy.

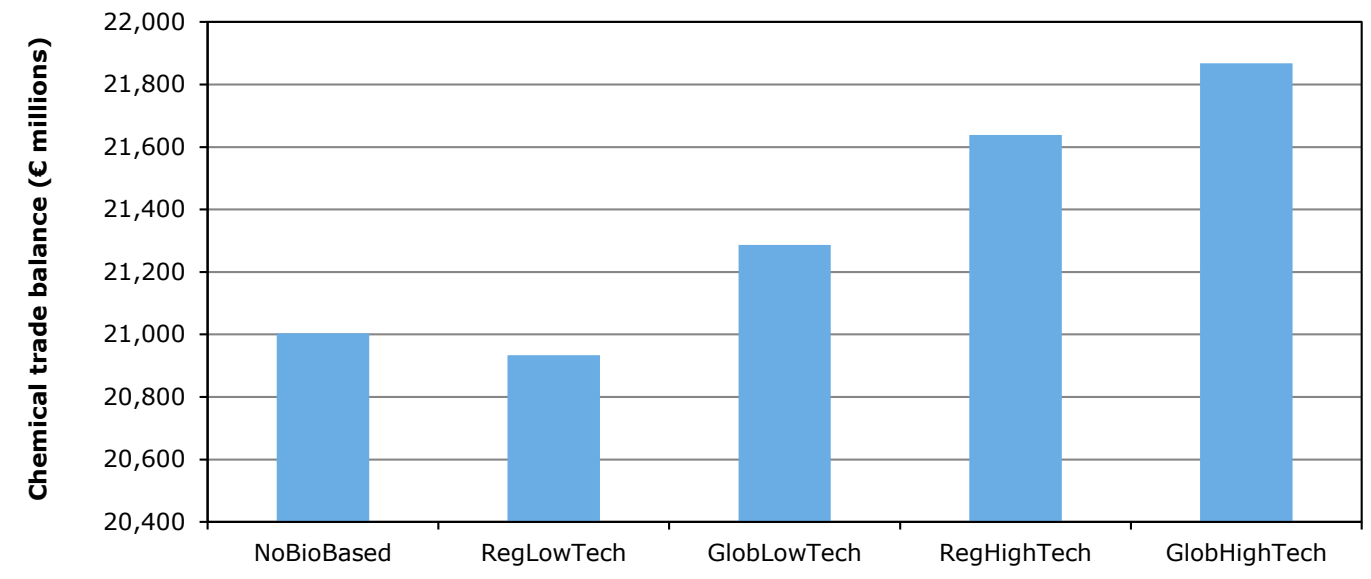

Figure 55 Trade balance (2030, $€$ millions) for the chemical industry

Figure 54 shows that the contribution of the chemical sector to the trade surplus is higher in the bioeconomy scenarios and especially in the HighTech scenarios.

- Figure 55 shows that the reduction in overall trade balance is lower in the HighTech scenarios than in the LowTech scenarios, as the chemical industry exports more as a results of rapid technical change in bio-based chemicals.

- The additional value of export of chemicals in the HighTech scenarios is $€ 0.8 \mathrm{bn}$ in the global scenario and $€ 0.6 \mathrm{bn}$ in the regional scenario. In the LowTech scenario, the contribution to the trade balance is $€ 0.3 \mathrm{bn}$ in the global and negative $(-€ 0.1 \mathrm{bn})$ in the RegLowTech scenario.

- The positive contribution of the chemicals sector dominates the increase in imports of biomass, as the total trade balance improves in the HighTech scenario compared to the LowTech scenario. 


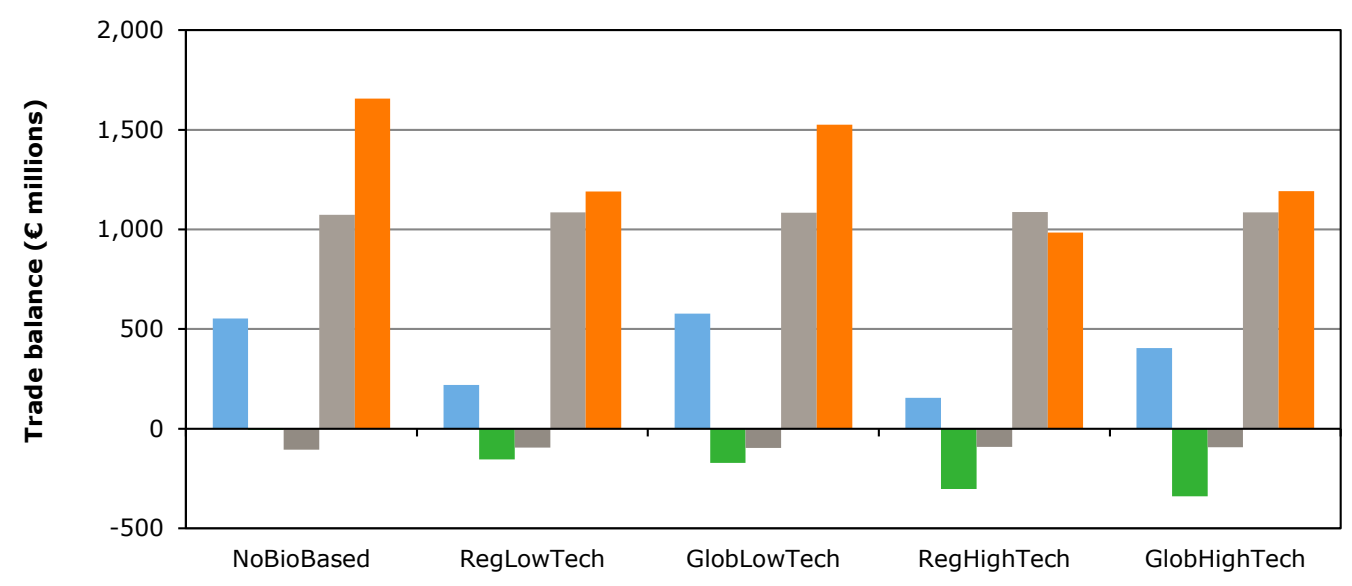

m crop sectors $\square$ biomass sectors $\square$ forestry $\square$ livestock sectors $\square$ total

Figure 56 Trade balance (2030, € millions) for biomass-related sectors

Figure 56 shows that biomass-related imports increase or biomass exports decrease in the MEV II scenarios relative to the NoBioBased scenario. This effect is larger in the HighTech scenarios than in the LowTech scenarios.

- Biomass imports (pellets, residues) increase in both HighTech scenarios by about $€ 200 \mathrm{~m}$ relative to the LowTech scenarios. There is almost no difference between the global and the regional scenario, as most biomass is in the form of pellets, which can be imported from EU regions (which is allowed in both scenarios).

- Agricultural exports decrease by $€ 250 \mathrm{~m}$ in the global scenario and by $€ 100 \mathrm{~m}$ in the regional scenario in the HighTech scenario relative to the LowTech scenario.

- The trade balance of biomass-related products improves in the GlobLowTech scenario relative to the NoBioBased scenario. This is because, for example, in this scenario biofuels are imported from the rest from the world to fill the biofuel mandate (see also Figure 55 below).

- The livestock sectors are hardly influenced by the bioeconomy.

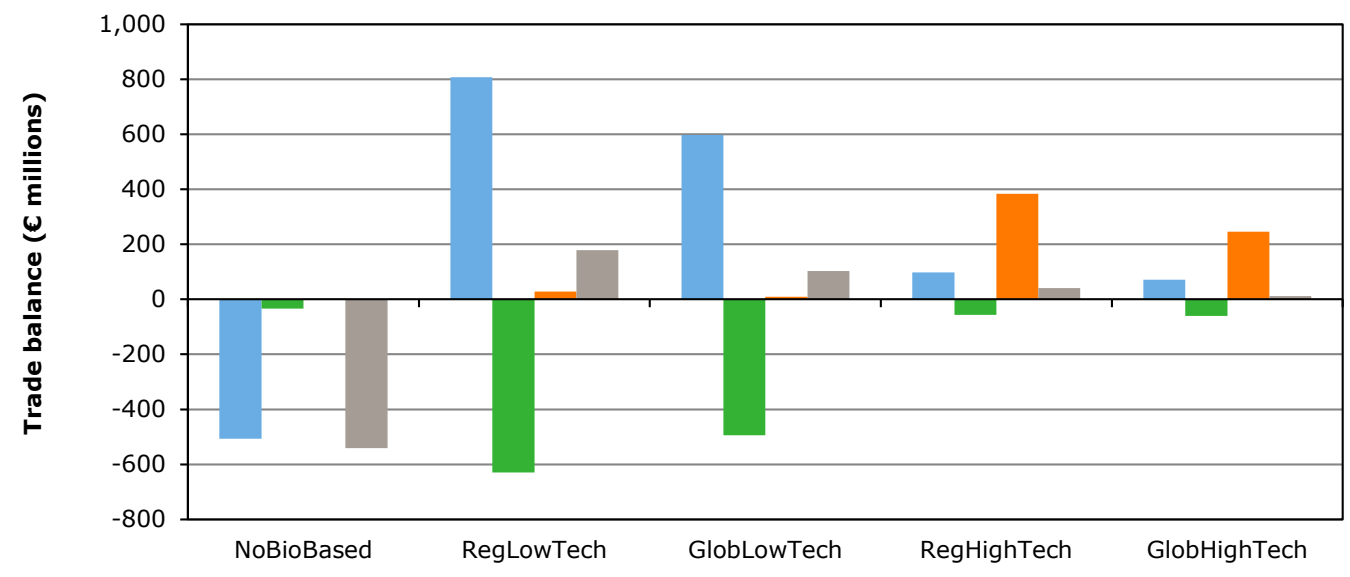

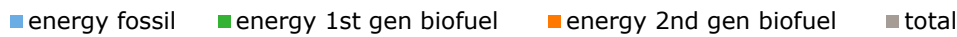

Figure 57 Trade balance (2030, $€$ millions) for biofuels and fossil energy 
Figure 57 shows that the energy trade balance of the Netherlands in 2030 is negative (by $€ 700 \mathrm{~m}$ ) in the NoBioBased scenario. It also shows that the energy trade balance improves in the bioeconomy scenarios relative to the NoBioBased scenario. In the low technology scenarios, fossil energy imports are replaced by first-generation biofuels. In the HighTech scenarios, the Netherlands exports secondgeneration biofuels.

- The total energy trade balance improves in the MEV II scenarios as fossil imports are replaced by imported and some domestically produced bio-based substitutes. The total energy balance of the Netherlands becomes positive.

- First-generation biofuels are imported, but second-generation biofuels are exported.

- In the LowTech scenarios, fossil energy imports are reduced more than imports of first-generation increase, as some of the biofuels are produced in the Netherlands.

- In the HighTech scenario, a different pattern is visible: first-generation biofuels are not used and substituted by domestically produced second-generation biofuels. The Netherlands becomes an exporter of second-generation biofuels.

- In the HighTech scenarios, the reduction of fossil imports is lower as energy is used to produce more second-generation biofuels and especially chemicals. In the LowTech scenarios, fossil energy is mainly replaced by bio-based alternatives, but in the HighTech scenarios new bio-based sectors grow within the Netherlands and need extra energy.

\section{Key message}

The total trade balance in the Netherlands deteriorates in bioeconomy scenarios, as the positive impact of RED policies and technological change in chemical technologies on the energy and chemical trade balance is more than offset by increased biomass imports and especially a deterioration of the other industries and services trade balance. The latter deteriorates as resources are pulled away from these sectors to less efficient sectors. The higher the technological change, the smaller the negative impact. Biomass (pellets, residues) and biofuels are imported to fulfil the RED mandates and primary agricultural exports decline. In the HighTech scenarios, the deterioration in the trade balance is less severe as chemical and second-generation biofuel exports increase. In the LowTech scenario, fossil energy is substituted by first-generation biofuels, but as part of these are produced domestically the energy trade balance improves. In the HighTech scenario, we get not only substitution of fossil by biobased substitutes, but also the second generation and chemical markets grow, which implies less savings on fossil energy imports. However, this results in bio-based exports that substitute for fossil energy in other countries.

\subsection{6 $\mathrm{CO}_{2}$ emissions}

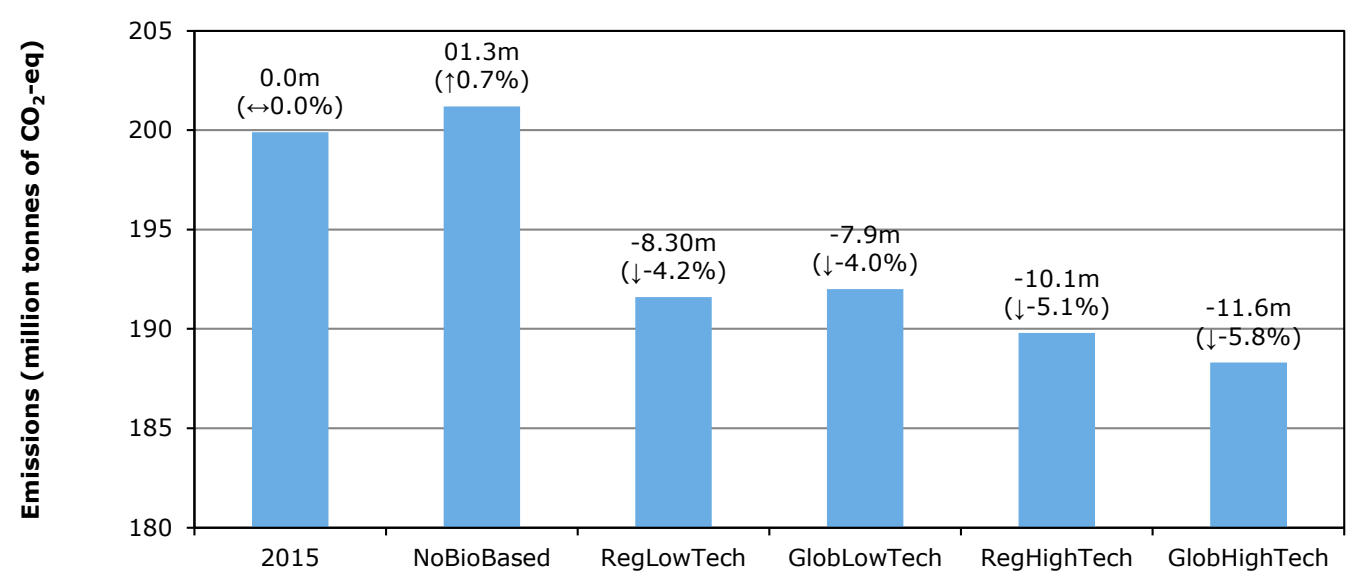

Figure 58 Total emissions in the Netherlands (2030)

- Figure 58 shows total emissions in the Netherlands in 2015 for the MEV II scenarios in $2030\left(\mathrm{CO}_{2}\right.$ eq). The introduction of the renewable energy policies and technological change reduce emissions by 4-6\%. 
In addition, high technological change can also contribute $1 \%$ in the regional scenario and $2 \%$ in the global scenario. Relative to 2015 , the NoBioBased scenario leads to slightly higher emissions as also current biomass use in fuels and electricity is supressed.

- In the LowTech scenarios, emissions decline by $8 \mathrm{mt}$ due to the introduction of mainly the renewable energy directives for fuels and electricity. This is a reduction of the total emissions by $4 \%$.

- In the high technology scenarios, technological change induces the substitution of fossil-based by bio-based technologies and this contributes another $1 \%$ in the regional and $2 \%$ in the global scenario.

\section{Key message}

Introduction of the renewable energy policies and technological change reduce total emissions in the Netherlands by $4-6 \%$. The introduction of the directives contributes $4 \%$, while high technological change contributes an additional $1 \%$ in the regional scenario and an additional $2 \%$ in the global scenario.

\subsection{Comparison between the bottom-up and the top-down analyses}

This section provides a general comparison between the outcomes of the bottom-up analyses and the top-down model. There are many differences between the two methodologies and despite these methodological differences the general trends are consistent between the models. Model outcomes are expected to be different as models follow different paradigms and techniques. Some of the key model differences are:

- MARKAL-NL-UU is a cost optimization model with detailed representation of technologies in the energy and chemical sectors, whereas MAGNET is a global general equilibrium model (maximize utility and minimize costs) that covers the whole economy at a more aggregated level.

- Biomass feedstocks are more detailed in MARKAL-NL-UU and are linked with specific conversion routes, whereas MAGNET has higher level of aggregation and application.

- MARKAL-NL-UU addresses the co-production of processes, whereas MAGNET addresses these in reduced form.

- MARKAL-NL-UU does not trade produced commodities (electricity, fuels, transport, chemicals) whereas MAGNET does.

- MARKAL-NL-UU assumes fixed biomass prices, whereas in MAGNET world and domesticprices are determined based on equilibrium between supply and demand.

- MARKAL-NL-UU assumes fixed demand for energy and non-energy services, whereas MAGNET prices are determined based on equilibrium between supply and demand. The latter are dependent on supply/demand elasticities and cost and market shares.

A challenge for the model comparison is that the outcomes of MARKAL are in physical flows and those of MAGNET are in monetary terms, making direct comparison difficult. Nevertheless, we attempt to draw conclusions based on the overall picture the two models present. 


\subsubsection{End use of biomass}

This section describes the model comparison for respectively biofuel, electricity and chemical demand.
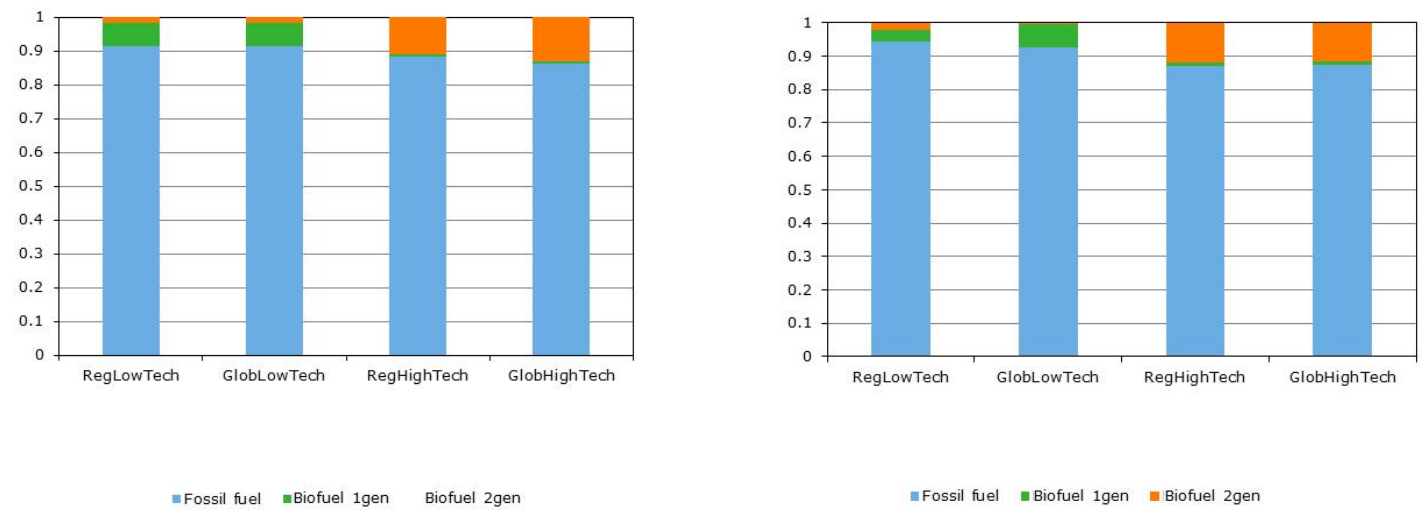

Figure 59 Transport fuel share of fossil and bio-based inputs in MAGNET (left-hand side) and MARKAL-NL-UU (right-hand side)

- Figure 59 shows the transport fuel shares of fossil and bio-based inputs are consistent between MARKAL-NL-UU and MAGNET. Biofuel shares in both models are limited and primarily driven by the blending policy in the low technology scenarios. This implies that mandates of $10 \%$ are filled with $7 \%$ first-generation and $1.5 \%$ second-generation biofuels (the latter counts double for the mandate).

- Biofuel shares in both models are higher in HighTech scenarios as especially second-generation biofuels become competitive. In the global high technology scenario, the biofuel share in MARKAL becomes $12 \%$ and in MAGNET $13 \%$. The main source in both models is second-generation biofuels (90-100\%).
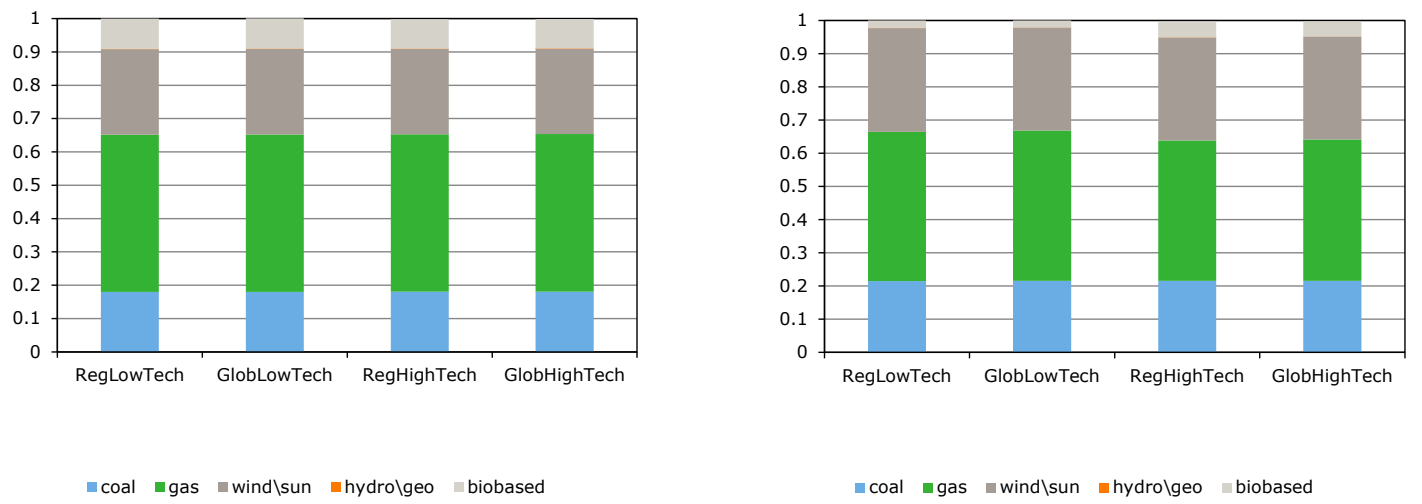

Figure 60 Electricity use in MAGNET (left-hand side) and MARKAL-NL-UU (right-hand side) (index number, Total RegLowTech $=1,2030$ )

Figure 60 shows the electricity use in the bottom-up and top-down modelling in 2030. Biomass use in electricity is limited across scenarios. In MAGNET, biomass use is slightly higher and constant across scenarios while for MARKAL biomass use is higher in the HighTech scenarios.

- Fossil energy shares are fairly equal between scenarios. Coal has a share of $20 \%$ and gas has a share of $45 \%$.

- The renewable energy share is therefore also consistent between the models and equal to about $35 \%$. 
- For both models, wind is the key renewable energy source. In MARKAL-NL-UU, the share in electricity use in 2030 is $31 \%$ while it is $25.5 \%$ in MAGNET results.

- MAGNET uses relatively more biomass and less wind than MARKAL-NL-UU. This difference is caused by the assumptions regarding wind energy. If more wind energy is available, less biomass has to be used.

Figure 61 shows the bio-based and fossil use in the chemical sector in 2030 in the Netherlands.

- Both models have low or moderate shares of bio-based chemicals in total chemicals. In MAGNET, the share of traditional chemicals (e.g. rubber) is almost $5 \%$, and new biochemicals (e.g. PE, PLA) contribute $1 \%$ in the LowTech and almost $4 \%$ in the HighTech scenarios.

- Both models show a higher increase in modern bio-based chemicals production in HighTech scenarios compared to LowTech scenarios.

- The bio-based chemical output in MARKAL is almost $1.8 \mathrm{mt}$ in the GlobHighTech scenario (see Figure 28) and the corresponding value in MAGNET is $€ 2 b n$ (Figure 45). This is consistent, given a price of $€ 1,000$ per tonne, which is plausible.

- The share of bio-based chemicals is lower in MARKAL-NL-UU than in MAGNET in the LowTech scenarios; this is due to the treatment of traditional bio-based chemicals (e.g. rubber) that are not modelled.

- Another methodological difference is that demand in MARKAL-NL-UU is fixed, and both higher technological change and a diverse technology portfolio lead to lower use of inputs. In MAGNET, demand is endogenous and technological change leads to an increase in the chemical sector and demand for inputs. Therefore, with higher technological change, the bars in the MAGNET figure increase (left, Figure 61) and the bars in the MARKAL-NL-UU figure decrease (right, Figure 61). To address the endogenous demand effect in the baseline scenario, we had MARKAL-NL-UU run an additional sensitivity demand scenario (see Section 5.1.5).

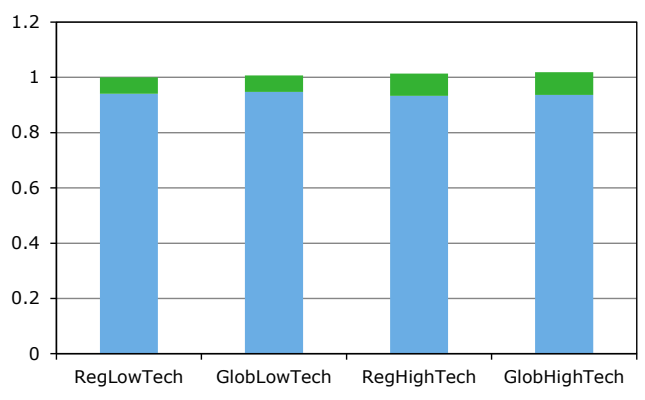

- fossil based —bio-based

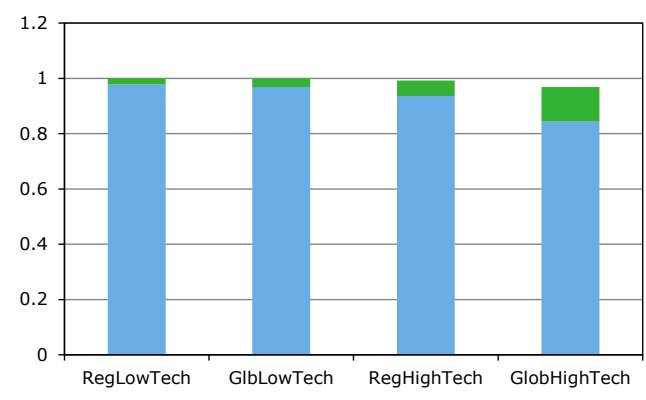

- fossil-based —bio-based

Figure 61 Bio-based and fossil input use in the chemical sector in Magnet (left-hand side) and in MARKAL-NL-UU (right-hand side) (index Total RegLowTech =1, 2030) 


\subsubsection{Biomass supply}
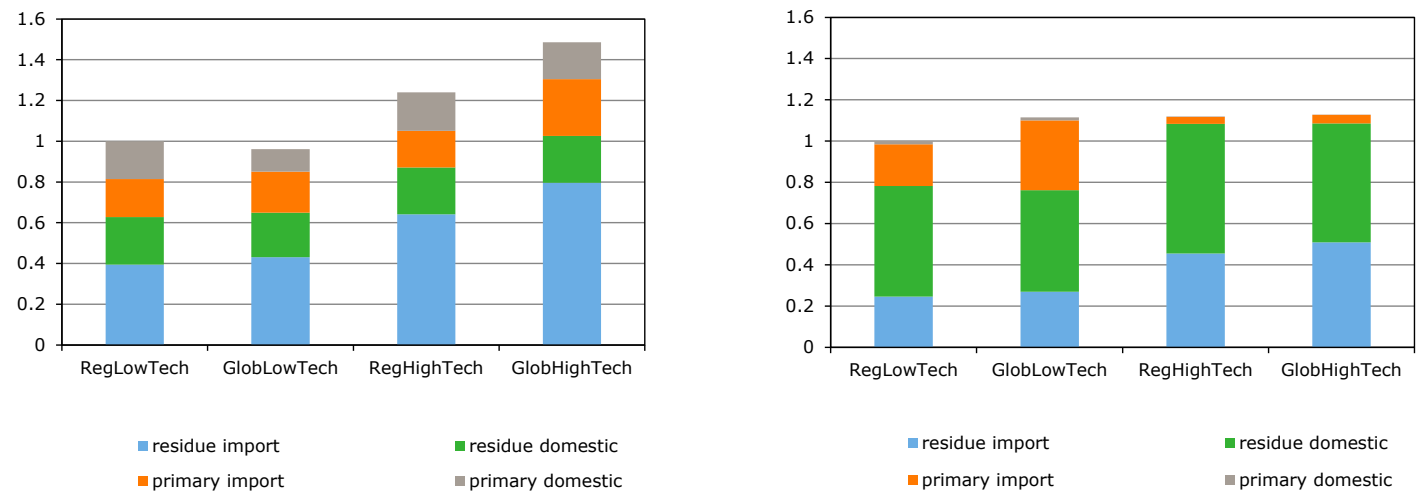

Figure 62 Biomass supply; Total level RegLowTech $=1,2030$

Figure 62 shows biomass supply in both models in 2030. The figures are more difficult to compare as there are differences in the biomass sources assumed in the two models, and MARKAL-NL-UU measures in PJ and MAGNET in $€$.

- Both models find that biomass use is highest in the HighTech scenarios. The increase in biomass use relative to the RegLowTech scenario in MARKAL-NL-UU (45\%, physical terms) is higher than in MAGNET (13\%, monetary terms).

- Both models find that domestic and imported residues are the largest source of biomass.

- Both models find that the share of domestic residues is fairly constant across scenarios, indicating that first domestic residues will be used in 2030 in the Netherlands. Residue imports increase in both models in the HighTech scenarios although the share is much higher in MARKAL-NL-UU than in MAGNET, possibly due to the higher disaggregation of feedstocks in the former model.

- Both models differ in the importance of primary domestic biomass. While it adds to $20 \%$ in MARKALUU-NL, it is minimal in MAGNET. In MAGNET, primary imports are important in the LowTech scenarios but almost disappear in the HighTech scenarios, while in MARKAL this level is fairly constant.

\subsection{Bioeconomy in Dutch provinces in 2030}

\subsubsection{Building regional bioeconomy strategies}

The implementation of the European bioeconomy is actuated by entrepreneurs (ranging from carbonbased industries to farmers and foresters) and political authorities, assisted by knowledge workers $(R \& D)$. The drivers are (1) the search for alternative resources for fossil fuels, (2) the response to climate warming by becoming as $\mathrm{CO}_{2}$ neutral as possible and (3) the industrial demand for new functionalities offered by bio-based materials and chemicals. Developing a bioeconomy is one of the paths to enhance regional competitiveness. This direction is especially supported by such EU initiatives as the Bioeconomy Strategy for Europe (EC, 2012). However, boosting regional competiveness is also emphasized in the fields of EU regional and industrial policy (EC, 2010b and 2014a). In this scope, the concept of Research and Innovation Strategies for Smart Specialisation (RIS3) has been introduced. Such strategies involve a process of developing a vision, identifying competitive advantages, setting strategic priorities and making use of smart policies to boost regional innovation in order to achieve economic growth and prosperity. This process can be regarded as a bottom-up entrepreneurial discovery involving key innovation stakeholders and businesses, rather than being a strategy imposed top-down: 'smart specialisation involves businesses, research centres and universities working together to identify a Member State or region's most promising areas of specialisation, but also the weaknesses that hamper innovation' (EC, 2014b). RIS3 encourages regions to adopt policies that are 
realistically tailored to their capabilities, opportunities and needs, acknowledging that there are different pathways for regional innovation and development. For the programming period 2014-2020, regions have to make an RIS3 strategy as a precondition for European Regional Development Fund (EFRD) funding.

In the Netherlands, RIS3 strategies have been formulated at the NUTS1 regional level (North Netherlands, West Netherlands, South Netherlands and East Netherlands). The four geographic areas have identified their focus economic activities around which capabilities, target markets and strategic development priorities are shaped. All have the bioeconomy and the knowledge-based-related economy on their priority list. Table 23 presents the RIS3 for South Netherlands, which comprises the provinces of North Brabant, Limburg and Zeeland (http://s3platform.jrc.ec.europa.eu/regions/n/4).

\subsubsection{Building regional bioeconomy clusters}

A bioeconomy cluster can be regarded as a geographical concentration of actors in vertical and horizontal relationships that are aiming to develop the bioeconomy. Given the broad coverage of sectors within the bioeconomy, its clusters might be rather heterogeneous in their specific focus. The bioeconomy cluster usually starts in one economic sector and in the course of time more economic sectors become involved due to cross-overs among sectors. The development of the cluster can be seen as a collective learning process of active and open minded entrepreneurs, R\&D institutes and policymakers, who continuously develop new technical knowledge, adopt innovations, and adapt to changing local and global circumstances. This learning process can be seen in terms of a strategy of the biocluster. The development and marketing of bioeconomy products does not differ from other products: the challenge is to introduce competitive bioeconomy products that can be sold in profitable quantities on the basis of their price, quality and service combination preferred by buyers over that offered by competing products. This implies that in the analysis of the development of the bioeconomy clusters, the same three factors play a role as in the case of clusters aiming at the introduction and marketing of televisions or cars: input-output linkages among firms, social capital and institutional thickness (Storper, 1995; Armstrong and Tailor, 2000; Putnam, 1993).

\section{Table 23}

Focus economic activities for South Netherlands

\begin{tabular}{|c|c|c|c|}
\hline Description & Capabilities & Target Markets & EU Priorities \\
\hline Organic aromatics & $\begin{array}{l}\text { 1. Manufacturing \& industry } \\
\text { 2. Chemicals \& chemical } \\
\text { products }\end{array}$ & $\begin{array}{l}\text { 1. Energy production \& } \\
\text { distribution } \\
\text { 2. Power generation/ } \\
\text { renewable sources }\end{array}$ & $\begin{array}{l}\text { 1. Sustainable innovation } \\
\text { 2. Sustainable energy \& } \\
\text { renewables }\end{array}$ \\
\hline $\begin{array}{l}\text { Promoting linkages between } \\
\text { research \& development } \\
\text { centres and diverse sectoral } \\
\text { clusters, promoting } \\
\text { implementation of newly } \\
\text { developed innovations }\end{array}$ & $\begin{array}{l}\text { 1. Services } \\
\text { 2. Scientific research \& } \\
\text { development }\end{array}$ & $\begin{array}{l}\text { 1. Manufacturing \& } \\
\text { industry }\end{array}$ & $\begin{array}{l}\text { 1. Specific local policy } \\
\text { priority }\end{array}$ \\
\hline $\begin{array}{l}\text { Research centre for food and } \\
\text { health }\end{array}$ & $\begin{array}{l}\text { 1. Services } \\
\text { 2. Scientific research \& } \\
\text { development }\end{array}$ & $\begin{array}{l}\text { 1. Human health \& social } \\
\text { work activities }\end{array}$ & $\begin{array}{l}\text { 1. Public health \& security } \\
\text { 2. Food security \& safety }\end{array}$ \\
\hline $\begin{array}{l}\text { Cluster development, linkages } \\
\text { between private sector and } \\
\text { educational research facilities }\end{array}$ & $\begin{array}{l}\text { 1. Services } \\
\text { 2. Education }\end{array}$ & $\begin{array}{l}\text { 1. Manufacturing \& } \\
\text { industry }\end{array}$ & $\begin{array}{l}\text { 1. Service innovation } \\
\text { 2. New or improved } \\
\text { organisational models }\end{array}$ \\
\hline
\end{tabular}

Source: S3Platform. 
The BERST project (www.BERST.eu) has explored the bioeconomy potential of EU regions and analysed a number of case studies from the following two perspectives:

1. Key assets that are enabling factors for developing bioeconomy clusters (Figure 63):

- Entrepreneurs and entrepreneurial culture (active, innovative entrepreneurs who want to invest in bioeconomy products).

- Policymakers who are willing to support the development of the bioeconomy (not only financial support, but also commitment and appropriate governance/institutional structures).

- Knowledge institutes that provide the technical knowhow and innovation for the development of bioproducts.

- Availability of biomass resources.

- Competitive bioeconomy products.

2. The long-run time horizon of bioeconomy clusters:

- Initial stage and take off (IS): introducing the bioeconomy in the regional planning agenda and creating the policy, socioeconomic and R\&D landscape for its establishment and operation (about 5 years).

- Drive to maturity (DMS): the first competitive bioeconomy products are sold on the market. The cluster grows with the setup of new companies, cluster infrastructure (incubator, training centre, etc.) has been established, and the cluster is able to attract both private and public funding (510 years).

- Age of mature production (MS): the cluster is able to produce competitive bioeconomy products at an extensive scale (10-20 years).

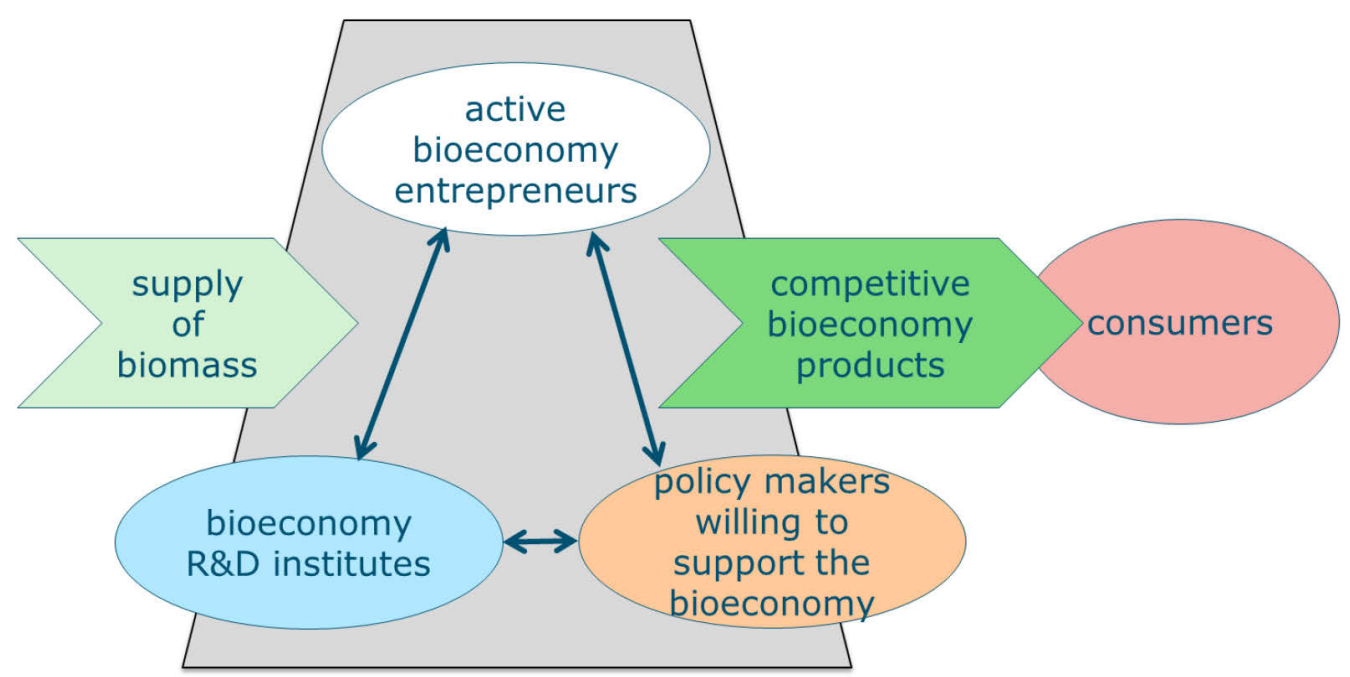

Figure 63 Conceptual model for the analysis of the strategy of a bioeconomy cluster

In principle, all regions are potentially 'bioregions'. The BERST project has developed tools and guidelines to help regions recognize their bioeconomy potential and then realize that potential. The BERST toolkit consists of:

- Catalogue of criteria and indicators that can describe the regional bioeconomy potential (http://berst.databank.nl/); see Figure 64 as an example for the province of North Brabant).

- Catalogue of instruments and measures that can support the regional bioeconomy potential

(https://berst.vito.be/).

- Catalogue of good practices and case studies (http://berst.databank.nl/).

- A bioregional network (www. berst.eu).

- Guidelines for elaborating regional profiles to prepare smart specialization strategies (http://berst.databank.nl/). 


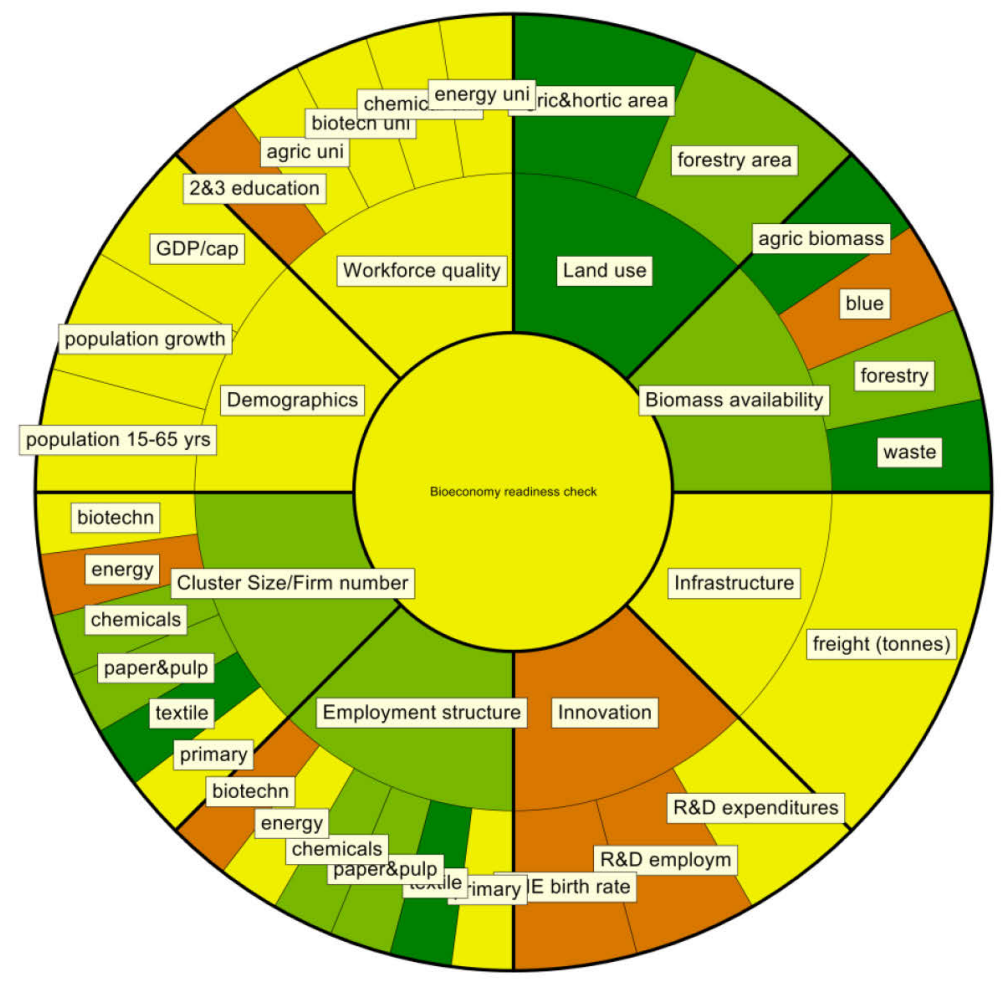

Figure 64 'Bioeconomy readiness check' for North Brabant compared to the Netherlands (z-scores, green means that the indicator scores above the Dutch average, yellow means that the indicator scores around the Dutch average and red means that the indicator scores below the Dutch average)

The inner circle of the above figure gives the key criteria that describe the regional bioeconomy: land use, biomass availability, infrastructure, innovation, employment structure, cluster size, demographics and workforce quality. Each criterion has the same weight in order to build the overall indicator that positions the region with regard to its bioeconomy competitive advantage. The outer circle gives the indicators that measure a specific criterion. Indicators have the same weight within the criterion. Green means that the indicator scores above the Dutch average, yellow means that the indicator scores around the Dutch average and red means that the indicator scores below the Dutch average.

The colours in the readiness wheel do not indicate a bad or a good, but they are helpful in giving direction to where regional stakeholders could make smart specialization strategy in order to strengthen the regional bioeconomy development. For a consistent comparison among regions, it is important that indicators are similarly and consistently measured across all European regions. Also it is important that the selected indicators make sense. Both issues need further improvement in order to better understand, to support and to strengthen the bioeconomy development of regions.

With regard to determining meaningful indicators, the innovation potential, for example, is more than the present indicators of $R \& D$ expenditure or SME birth rate can reveal (these were the best indicators we could find in European data sources). In the BERST project, it has been suggested to add as an indicator the ecosystem, which should be seen as a network of partners, as a set of shared facilities and as having characteristic ways of interactions.

The regional benchmark in Figure 64 has been conducted at the national level. It is frequently suggested by regional stakeholders to upgrade the tool/data for all EU Member States' regions. That would provide the States with insight into the regions' bioeconomy competitive advantages at the EU level. Benchmarking is only effective when regions share similar structural conditions that are relevant to innovation-driven development (social, economic, technological, institutional and geographical characteristics). Such characteristics cannot easily be changed in the short term. To help regions to recognize these similarities, the S3/RIS3 platform (http://s3platform.jrc.ec.europa.eu/regions/nl4) has launched an interactive tool ('Benchmarking Regional Structure') that uses a participative cluster 
methodology to identify reference regions across Europe. The S3/RIS3 database covers general structure data for NUTS2 regions, whereas the focus of the BERST database is on bioeconomy structure data for NUTS3/NUTS2 regions. Embedding the BERST database/methodology with the S3 database/methodology will provide a better option for regions to understand their comparative advantages at the EU level, to learn from other regions and to specify smart strategies in order to strengthen the bioeconomy development.

\subsubsection{Bioeconomy in Dutch provinces}

In general the advice to regions is 'to start from what is available in the region and make strategy around it. That is valid to all regions in the world' (Rogier van der Sande, rapporteur of Committee of the Regions; speech at Open Days of the Regions in Brussels, 13 October 2015). This view was the starting point in the MEV study for allocating the projected national value added and employment of bioeconomy sectors for 2030 over provinces. The current bioeconomy value added (see Section 2.2) and employment structures over Dutch geographic regions are assumed to form the base for 2030.

MAGNET has provided developments for the value added (in $€$ millions) that are generated by the new bio-based sectors at the national Dutch level, which are respectively:

- The biomass producing sector.

- The biofuel sector.

- The biochemical sector.

- The bioenergy sector.

The shift-share method (Dunn, 1960) was applied to downscale these national level values over the Dutch provinces in respectively the reference year 2015 and under the four scenarios in 2030. This descriptive shift-share method takes into account three components:

- National growth effect (NS): portion of the change attributed to the total growth of the national economy. It shows the theoretical change in the province value added had it increased by the same percentage as the national economy.

- Industry mix effect (IM): portion of the change attributed to the performance of the specific economic industry. It shows the theoretical change in the province value added had it increased by the same percentage as the industry nationwide, minus the national growth effect.

- Regional share effect (RS): portion of the change attributed to regional influences, and is the component of primary concern to regional analysts. It shows the actual change in the province value added minus the previous two effects.

The regional change in respectively value added and employment within the bioeconomy sectors i $(\Delta e)$ between 2015 and 2030 is defined as the sum of the three shift-share effects:

$$
\Delta e(i)=e(i, t)-e(i, t-1)=N S(i)+I M(i)+R S(i)
$$

The regional share (RS) component was approximated by taking the changes in the sectoral value added in the previous period (2003-2015). The value added (in 2015 prices) of the four bio-based sectors would increase by around 50\% over the period 2015-2030, and expectedly the increase of the HighTech scenarios would be the highest.

The following figures show how the values added of the new bioeconomy sectors develop between 2015 and 2030. For 2030, we present the outcomes for the two extreme scenarios, namely the RegLowTech scenario and the GlobHighTech scenario. It should be noted that if a specific bioeconomy sector was not present in a province in 2015, based on the applied assumptions it will not be there in 2030 either (see Figure 59 for biofuels). 


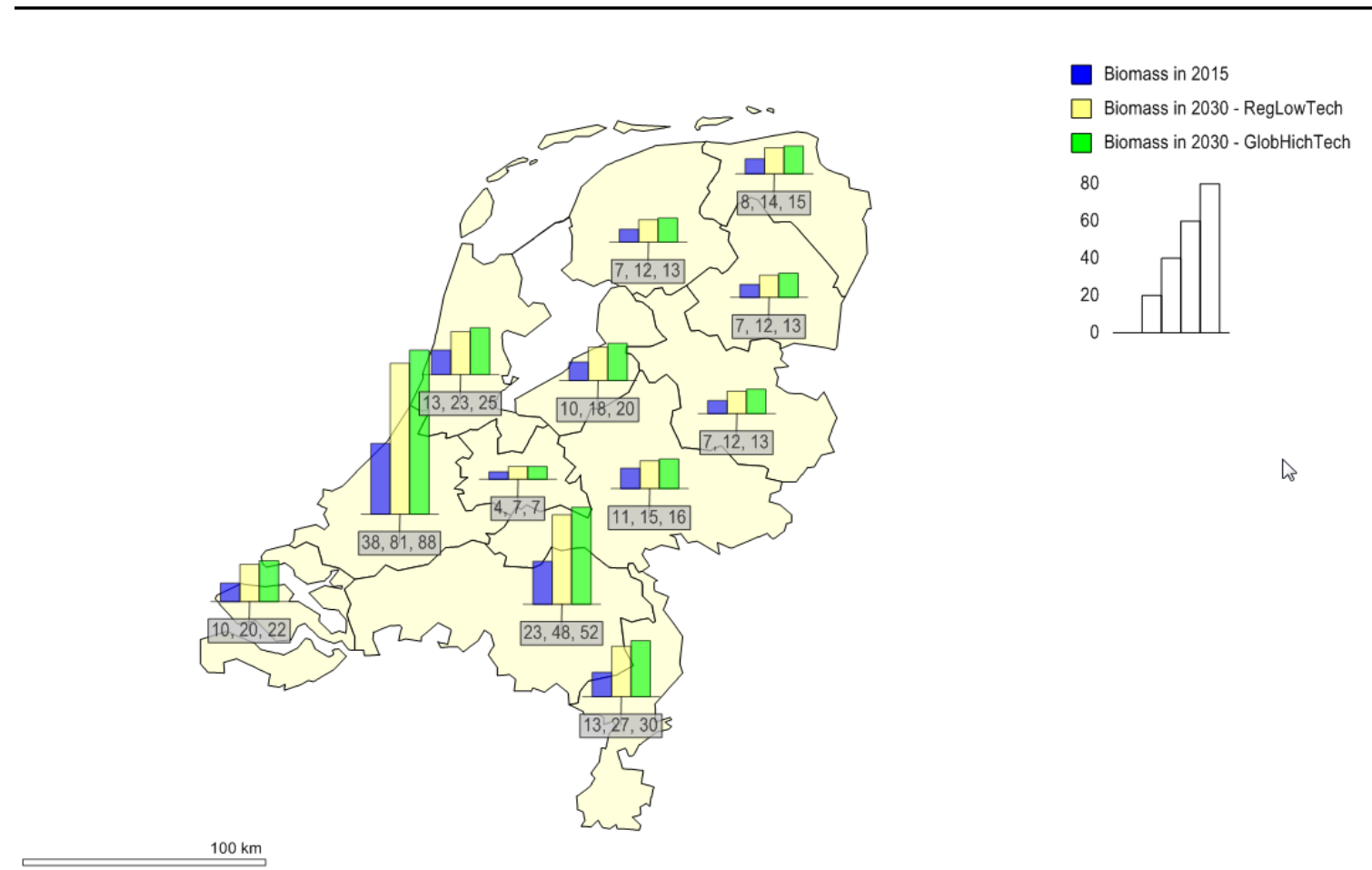

Source: LEI

Figure 65 Value added ( $€$ millions) of biomass sector in Dutch provinces, 2015 and 2030 scenarios

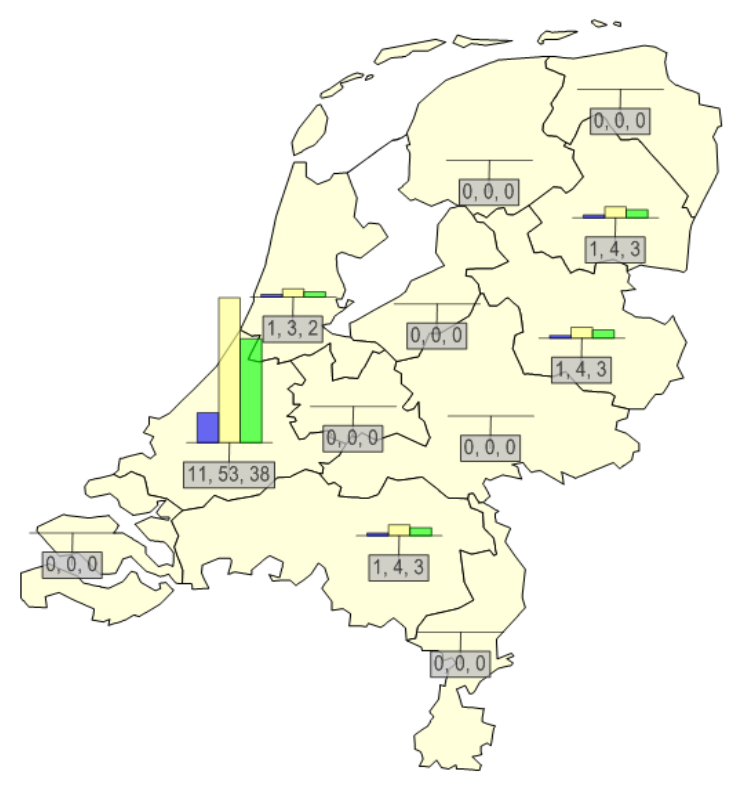

Biofuels in 2015

$\square$ Biofuels in 2030 - RegLowTech

$\square$ Biofuels in 2030 - GlobHighTeci

60

45

30

15

0

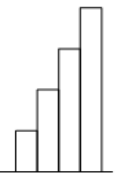

$100 \mathrm{~km}$

Source: LEI

Figure 66 Value added ( $€$ millions) of biofuel sector in Dutch provinces, 2015 and 2030 scenarios 


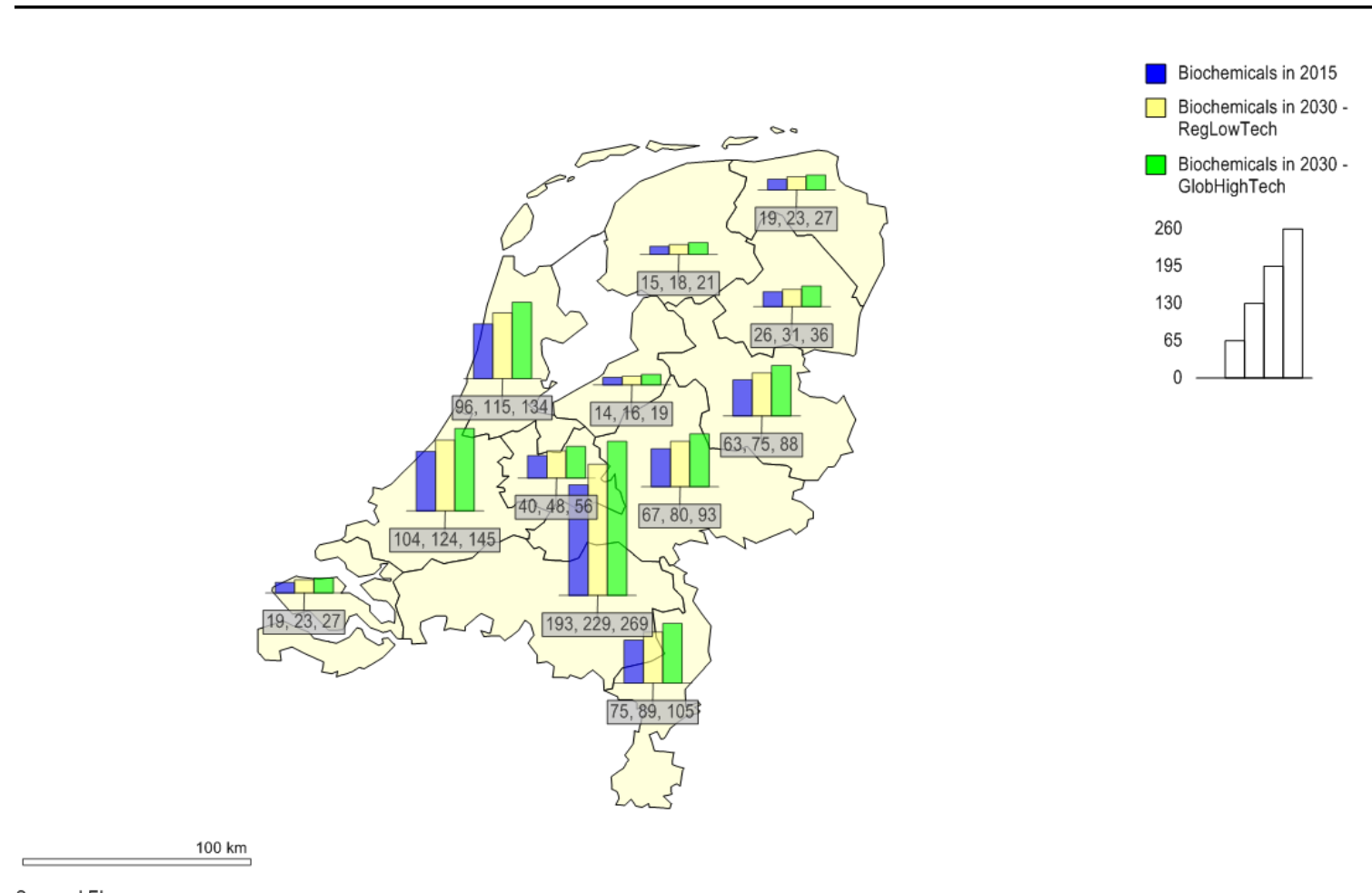

Source: LEI

Figure 67 Value added ( $€$ millions) of biochemical sector in Dutch provinces, 2015 and 2030 scenarios

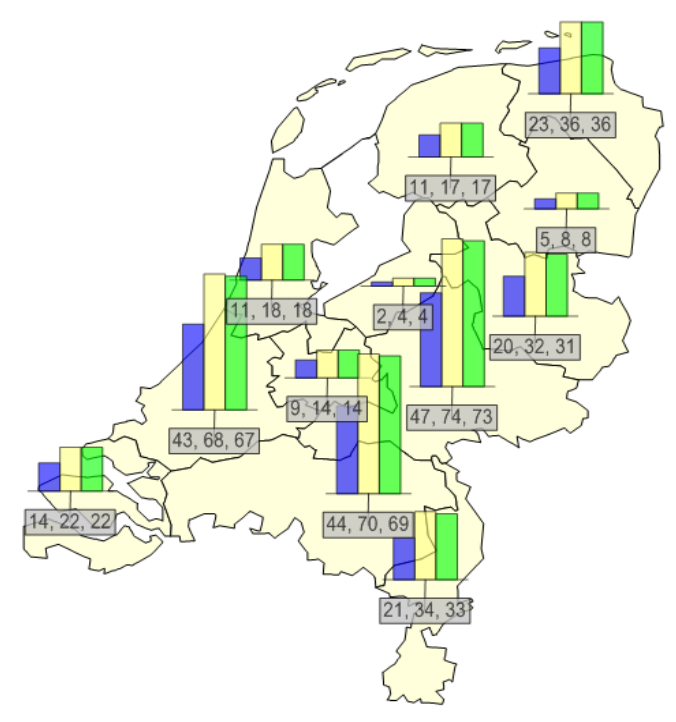

Bioenergy in 2015

$\square$ Bioenergy in 2030 - RegLowTech

$\square$ Bioenergy in 2030 - GlobHighTech

$100 \mathrm{~km}$

Source: LEI

Figure 68 Value added ( $€$ millions) of bioenergy sector in Dutch provinces, 2015 and 2030 scenarios 


\section{$5 \quad$ Sensitivity analysis}

Section 5.1 presents the sensitivity analyses results for the Netherlands until 2030 of the bottom-up analyses performed by the MARKAL-NL-UU model. Section 5.2 presents the results of the top-down analyses.

\subsection{Bottom-up MARKAL-NL-UU projections}

In this section, we present the results of varying key inputs to the model such as fossil fuel prices (Section 5.1.1) and domestic biomass supply potentials (Section 5.1.3). Furthermore, we performed additional what-if analysis for various scenarios such as biogas production (Section 5.1.2), emission reduction scenarios (Section 5.1.3), biojet fuel production (Section 5.1.4) and reduced demand for chemicals (Section 5.1.5).

\subsubsection{Fossil fuel prices}

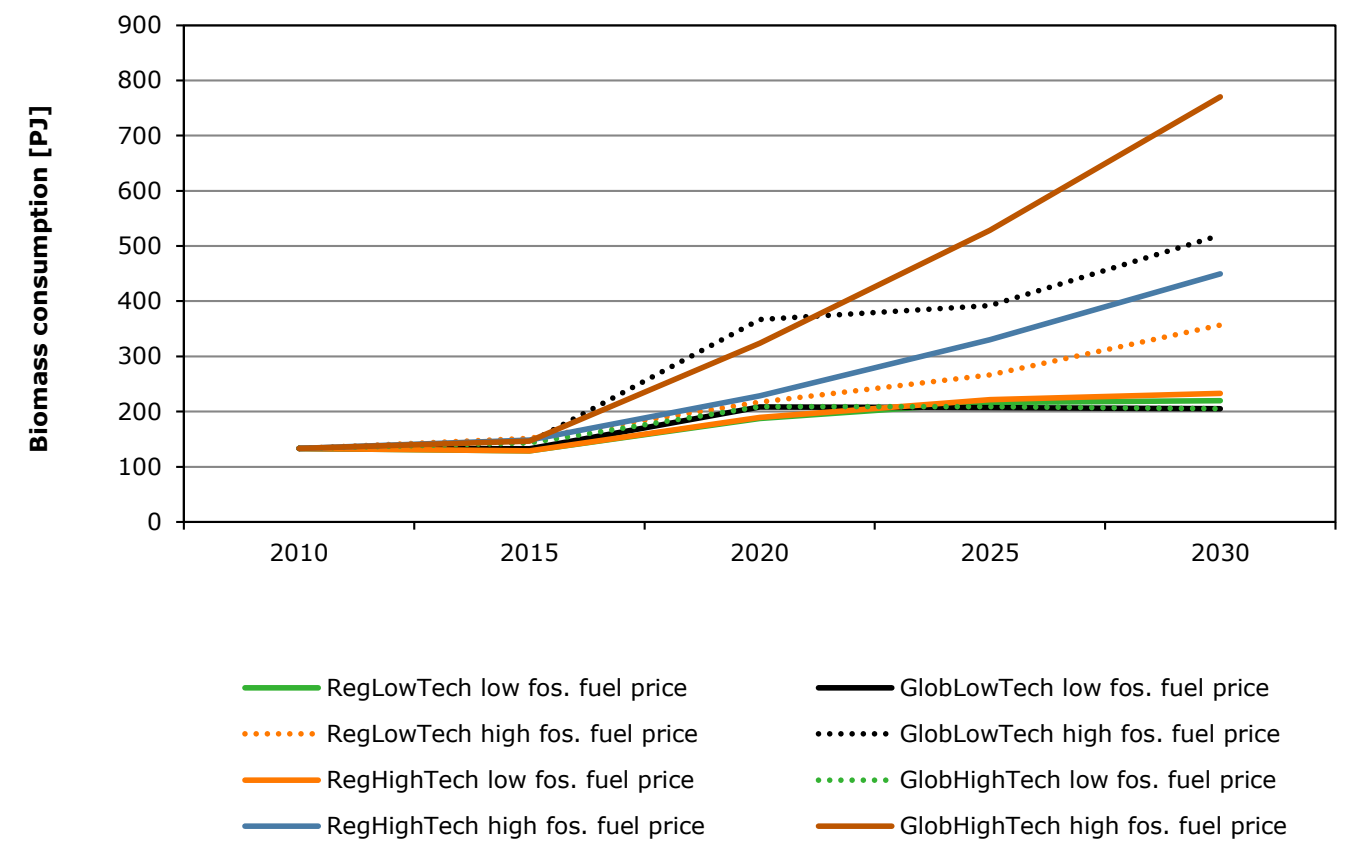

Figure 69 Biomass consumption expressed as primary energy in fossil fuel price variation scenarios ( $\pm 50 \%$ of reference fossil fuel price) 
The price of fossil fuels is a key input parameter and determinant of biomass deployment pathways. ${ }^{20}$ As shown in Figure 69, fossil fuel prices have a significant effect on the results as they are correlated with the competitiveness of fossil alternatives across all sectors.

- High fossil fuel prices increase biomass consumption by a factor of 1.5-2.2 (356-770 PJ) across the scenarios. Global trade scenarios indicate higher biomass consumption levels than their regional trade scenario counterparts. The higher range reaches two thirds of the biomass supply potential assumed in the global trade scenario ( $1 \mathrm{EJ})$.

- On the contrary, low fossil fuel price scenarios limit biomass consumption to 205-230 PJ (6-40\% lower compared to their counterparts using reference fossil fuel prices. The steepest reduction is in high technology development scenarios. Low technology development scenario outcomes remain largely unaffected by the assumed low fossil fuel prices. The narrow biomass consumption bandwidth across all scenarios under low fossil fuel prices leads to the conclusion that technology development rates are of secondary importance under such circumstances.

- Other renewables (primarily wind) are affected only under high fossil fuel price scenarios. Wind electricity increases by approximately $60-75 \%$ compared to reference scenarios.

- Under high fossil fuel prices, there is a notable decrease in demand for transport fuels in order to meet road transport needs (which is achieved by deploying more efficient hybrid vehicles). In addition, high fossil fuel prices make other biomass conversion technologies cost-competitive (e.g. methanol-to-olefins, or pyrolysis fuels).

- Electricity from biomass also increases to roughly $30 \mathrm{PJ}$ (from $20 \mathrm{PJ}$ ) in RegHighTech scenarios to 45 PJ (from 20 PJ) in GlobHighTech, primarily due to higher output from biochemical and thermochemical biorefineries. In low technology development scenarios, no significant increase in electricity output from biomass occurs. This points to the synergies across sectors under high fossil fuel prices that are enabled by technology advancements.

- The chemical sector is greatly affected by fossil fuel price inputs. High fossil fuel prices lead to 1.25$4.5 \mathrm{mt}$ of bio-based chemical output compared to the $0.65-1.75 \mathrm{mt}$ of total bio-based chemical output found in reference scenarios from a range of technologies (also from new technologies, namely methanol-to-olefins); on the contrary low fossil fuel prices greatly limit bio-based chemical output to 0.1-0.3mt (PLA in low technology development and PEF in high technology development).

- Low fossil fuel prices also affect road transport sector outcomes. In low technology development scenarios, transport fuel demand remains the same as in the reference scenarios. Biofuels are supplied to meet blending targets. In high technology development scenarios, lignocellulosic ethanol is deployed and blending targets are exceeded in order to meet the renewable energy share in 2030. However, FT technologies, which were found to be key in reference scenarios, are not deployed in global scenarios.

- A direct consequence of fossil fuel price variation is on emission reduction (Figure 70). Under high fossil fuel prices, the total emissions are 105-125mt (15-30\% emission reduction in 2030 compared to 1990 levels). Under low fossil fuel prices, the total emissions are around $140 \mathrm{mt}$ across all scenarios, that is, they are comparable to 1990 levels (i.e. emission reduction is primarily driven by policies and only $2 \%$ emission reduction is achieved compared to 1990).

\footnotetext{
${ }^{20}$ Transport costs of biomass due to fuel consumption (global and regional) have been correlated with increase and decrease of fossil fuel prices. This simplified approach ignores increase/decrease of biomass supply costs due to fossil fuel consumption in other parts of the supply chain (e.g. diesel in biomass production).
} 


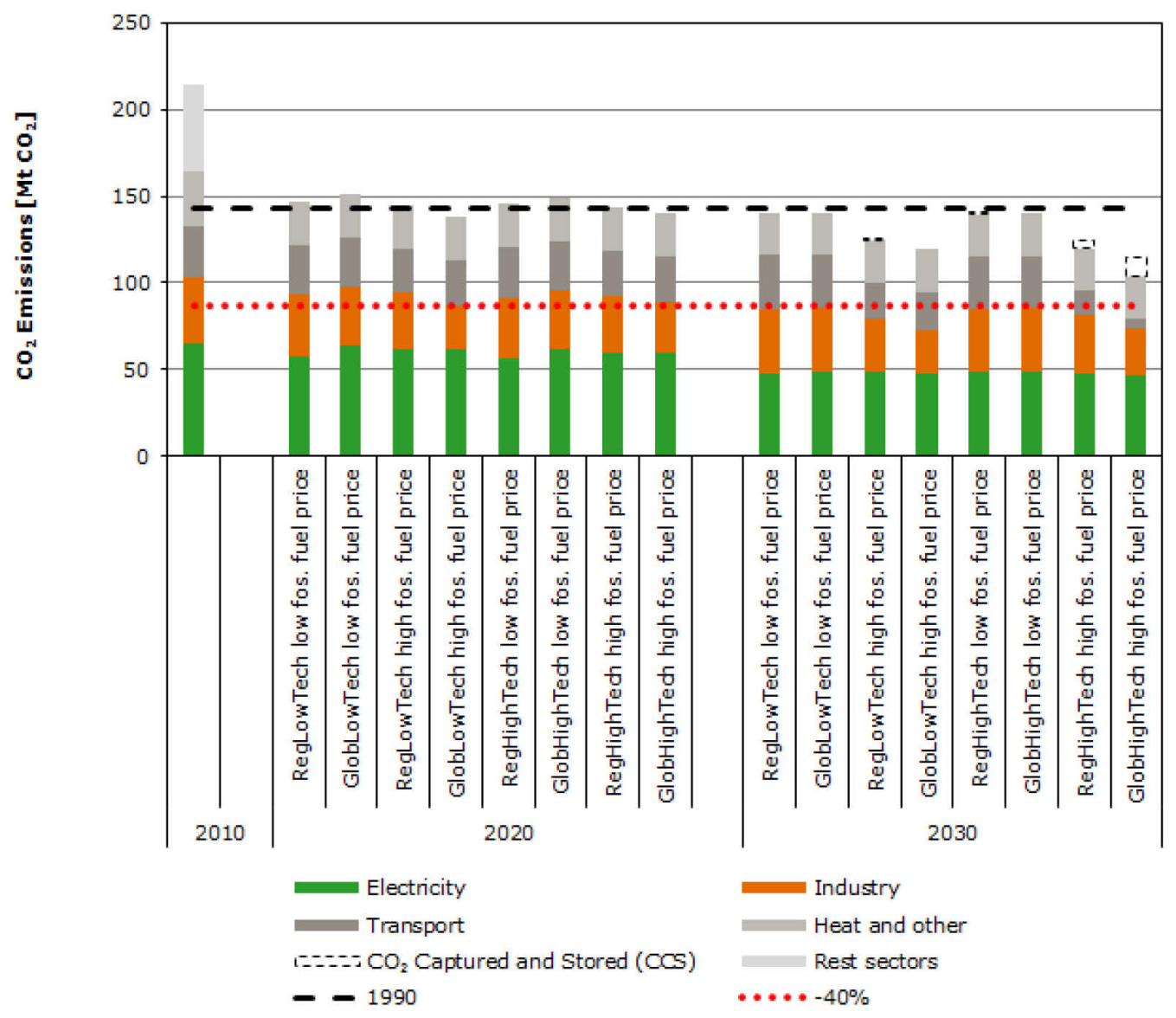

Figure 70 Direct $\mathrm{CO}_{2}$ emissions under high and low fossil fuel price scenarios in the Netherlands in 2010-2030

\section{Key message}

Fossil fuel price variation greatly affects the deployment potential of biomass and other renewable energy technologies, biomass consumption, demand reduction (e.g. transport) and emission levels. With high fossil fuel prices, we almost reach constraint levels of cost-effective and sustainable biomass supply, and strong emission reduction is achieved especially under high-tech scenarios; with low fossil fuel prices, only existing policy requirements are met regarding renewable energy share and blending targets, and there is no emission reduction compared to 1990.

\subsubsection{Biogas}

Under reference scenarios, large quantities of manure and other digestion feedstocks $(\sim 50 \mathrm{PJ})$ are not utilized to produce, for example, biogas and supply it to the energy system. Co-digestion, CHP production from biogas, and biogas upgrade to green gas are less cost-effective than other alternatives. Nevertheless, wet biomass makes up approximately $30 \%$ of the total domestic biomass potential. At the same time, manure must be treated. We therefore applied co-digestion as a mandatory treatment method and assessed the effects on the Dutch energy and non-energy system. 


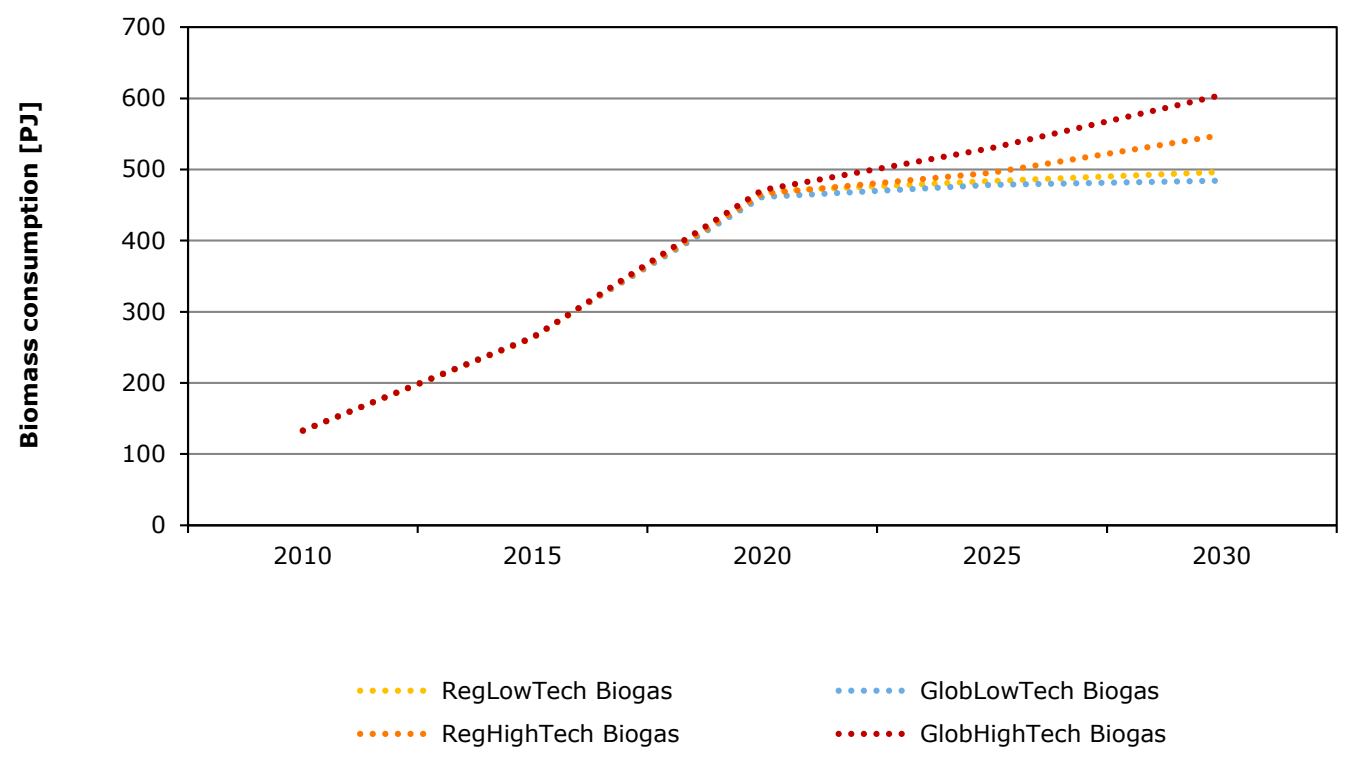

Figure 71 Biomass consumption in the Netherlands in 2010-2030 under mandatory manure treatment scenario

- There is a significant increase in biomass consumption levels primarily due to the large quantities of co-digestate that are required ( $250 \mathrm{PJ}$ ). The available domestic and EU co-digestion feedstocks (typically energy maize or other grasses) potential is approximately $30 \mathrm{PJ}$; therefore additional production is required to supply co-digestion feedstocks for manure treatment. Biomass consumption increases by almost a factor of two, from 224-345 PJ (reference scenarios) to 485-600 $\mathrm{PJ}$ (manure treatment scenarios).

- Biogas is further converted into green gas and used as a natural gas substitute for heat in agriculture, houses, industry and non-ETS electricity sectors. This pathway therefore also contributes to the renewable energy share mandate of the EU RED.

- However, a direct consequence is that smaller quantities of solid biomass for heat are required, as found in the results for reference scenarios. In short, model outcomes show that when forcing manure treatment, green gas replaces a renewable resource when compared to scenarios without manure treatment.

- This impacts emission reduction levels where manure treatment scenarios are shown to lead to lower emissions of $\mathrm{CO}_{2}(2-5 \mathrm{mt})$ compared to the reference scenarios in 2030 (Figure 64).

- Mandatory manure treatment to produce biogas and the latter's subsequent upgrade to green gas creates additional system costs of approximately $€ 400-500 \mathrm{~m} /$ year (see Appendix 2). 


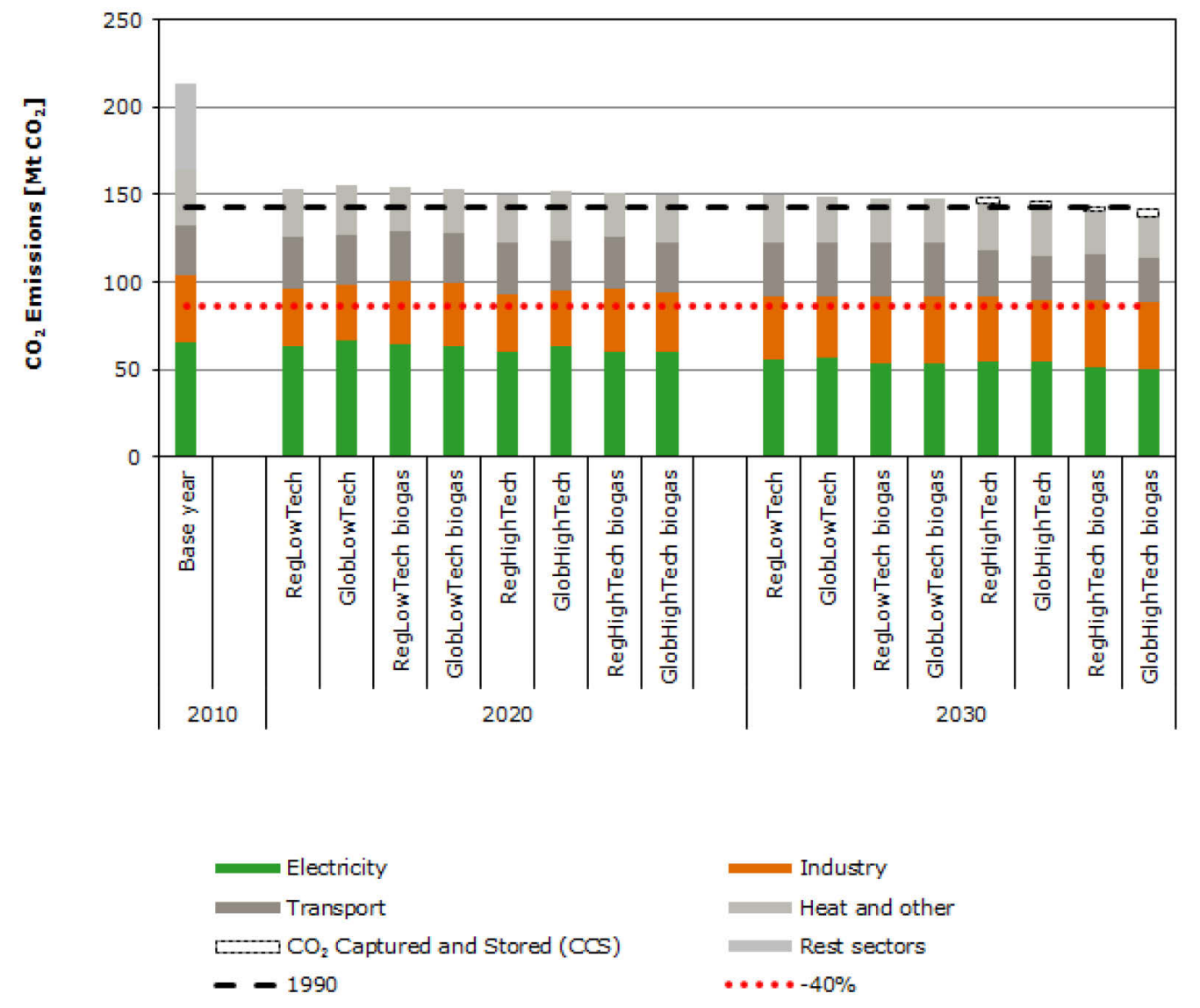

Figure 72 Direct $\mathrm{CO}_{2}$ emissions in biogas scenarios in the Netherlands in 2020-2030

\section{Key message}

If manure treatment is a prerequisite and co-digestion is the principal treatment technology applied, biomass consumption levels increase by almost a factor of 2 compared to the reference scenarios. This is primarily due to the large quantities of co-digestate required (e.g. energy maize). Most costeffective is the upgrade of biogas to green gas and injection into the grid. This supplies several sectors with renewable heat and contributes to the EU RED renewable energy share mandate, thereby reducing the use of solid biomass in industrial biomass heat boilers, which is dominant in the reference scenarios. An implication of this is the short-term increase in emissions by 2020 in regional scenarios due to the transport and production of co-digestate, which is mitigated later on in the time horizon, when all scenarios indicate overall emission reduction compared to reference conditions.

\subsection{3 $\quad \mathrm{CO}_{2}$ emission scenarios}

The two scenarios assessed in this study are for a high $\mathrm{CO}_{2}$ tax according to the $450 \mathrm{ppm}$ scenario of the World Energy Outlook (IEA/OECD, 2014) and an emission cap assuming 40\% emission reduction compared to 1990 (Figure 73 and Figure 74, respectively). 


\subsubsection{1 $\mathrm{CO}_{2}$ emission tax at $450 \mathrm{ppm}$}

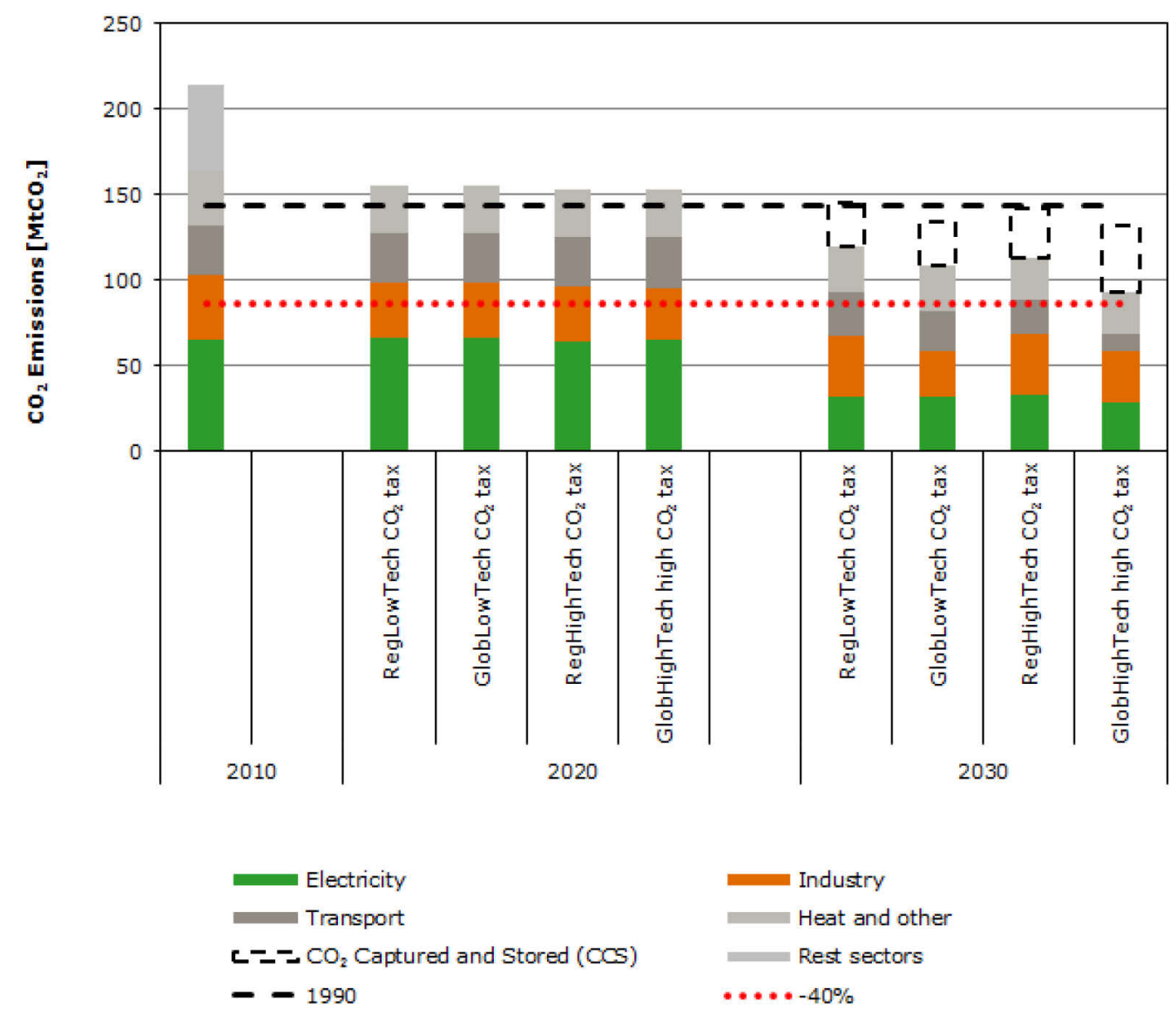

Figure 73 Direct $\mathrm{CO}_{2}$ emissions in the Netherlands in 2010-2030 based on a high $\mathrm{CO}_{2}$ tax

- A high $\mathrm{CO}_{2}$ emission tax leads to a reduction of $\mathrm{CO}_{2}$ emissions in the order of $15-35 \%$ by 2030 compared to 1990 . The largest reduction is in global trade scenarios, where the largest quantities of biomass are consumed (420-630 PJ), in combination with CCS deployment (25-40mt of $\mathrm{CO}_{2}$ stored) and a significant cut-back of emissions in the electricity sector (through CCS) and the transport sector (through demand decrease and large biofuel supply).

- Emission reduction in transport is achieved primarily through decreased demand and the deployment of hybrid vehicles. In view of limited conversion technologies, low technology development scenarios show a $20 \%$ reduction in demand, while high technology development scenarios show a $10 \%$ decrease. In addition, in the global trade scenario combined with high technology development rates, larger biofuel quantities are supplied ( $40 \mathrm{PJ}$ of biofuel, which also deliver $0.9 \mathrm{mt}$ of bio-based chemicals (olefins)).

- The renewable energy share in 2030 is $17-28 \%$, which is above policy targets.

- Looking at the results of the GlobHighTech scenario, we note that a combination of a high $\mathrm{CO}_{2}$ tax incentivizes CCS, biofuel supply and more efficient modes of transport, and emission targets are close to being realized. 


\subsubsection{Emission cap}

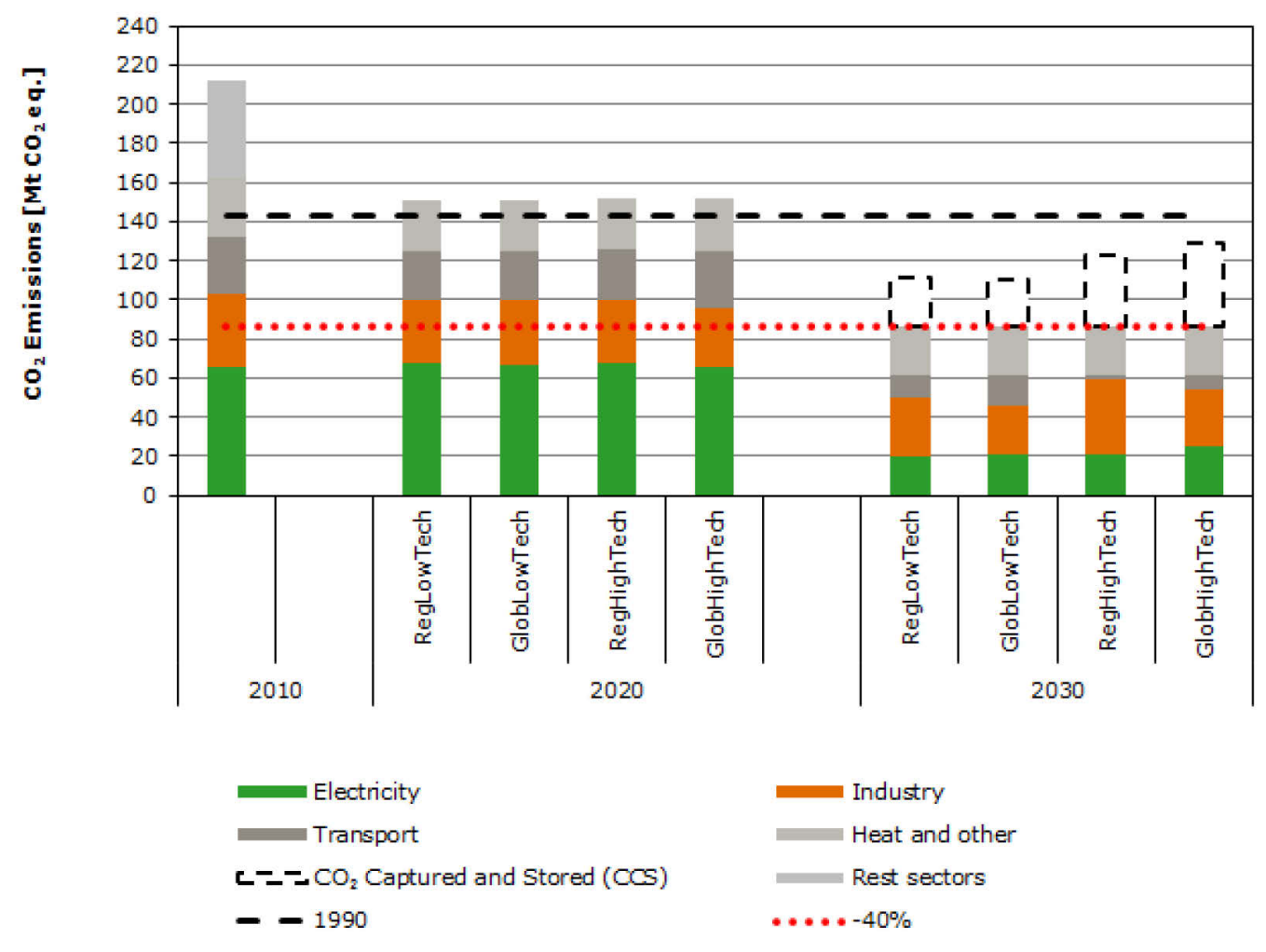

Figure 74 Direct $\mathrm{CO}_{2}$ emissions in the Netherlands in 2010-2030 based on a national $\mathrm{CO}_{2}$ emission ceiling of $-40 \%$ in 2030 compared to 1990

Under the emission cap scenario (40\% emission reduction compared to 1990 levels), all reference scenarios meet the target of emitting no more than $87 \mathrm{mt}$ of $\mathrm{CO}_{2}$ (domestic emissions, i.e. excluding indirect emissions). To do so, deployment of CCS is required (in the order of 25-40mt of $\mathrm{CO}_{2}$ ). Large emission reductions are achieved by the electricity and road transport fuel sectors. Furthermore, additional costs across the reference scenarios in 2030 show that RegLowTech leads to the highest additional total system costs (around $€ 1.5 \mathrm{bn} /$ year) and GlobHighTech to the lowest, namely of around $€ 700 \mathrm{~m} /$ year. The other two scenarios lead to similar additional system costs, which leads to the conclusion that access to low cost biomass or technology deployment at high rates in the Netherlands have similar effects (for more details, see Appendix 2).

\subsubsection{Aviation}

Assuming free competition of biofuels for aviation with fossil kerosene (i.e. no blending mandate for biojet fuels), the demand is met exclusively by fossil resources in low technology development scenarios across the whole modelling period while FT biojet is supplied to the aviation sector only in 2030 ('no mand' scenarios in Figure 75). Including the aviation sector without mandate in the Dutch energy system does not change the results significantly from reference scenarios, with the following exceptions:

- Biomass consumption in GlobHighTech increases by roughly 8\% (375 PJ compared to 345 PJ by 2030) and by $5 \%$ in RegHighTech. This increase is primarily due to used cooking oil supplied to the hydrogenation facility in the Netherlands, which supplies biofuels to the market. At the same time, smaller quantities of solid biomass are required for heat in industrial biomass boilers to meet the EU RED target and these are partly redirected to FT fuel production.

- Noticeable is the shift from biodiesel to HRD diesel across all scenarios. In addition, high technology development scenarios exceed the blending target as a cost-efficient means to meet EU RED renewable energy share target. 


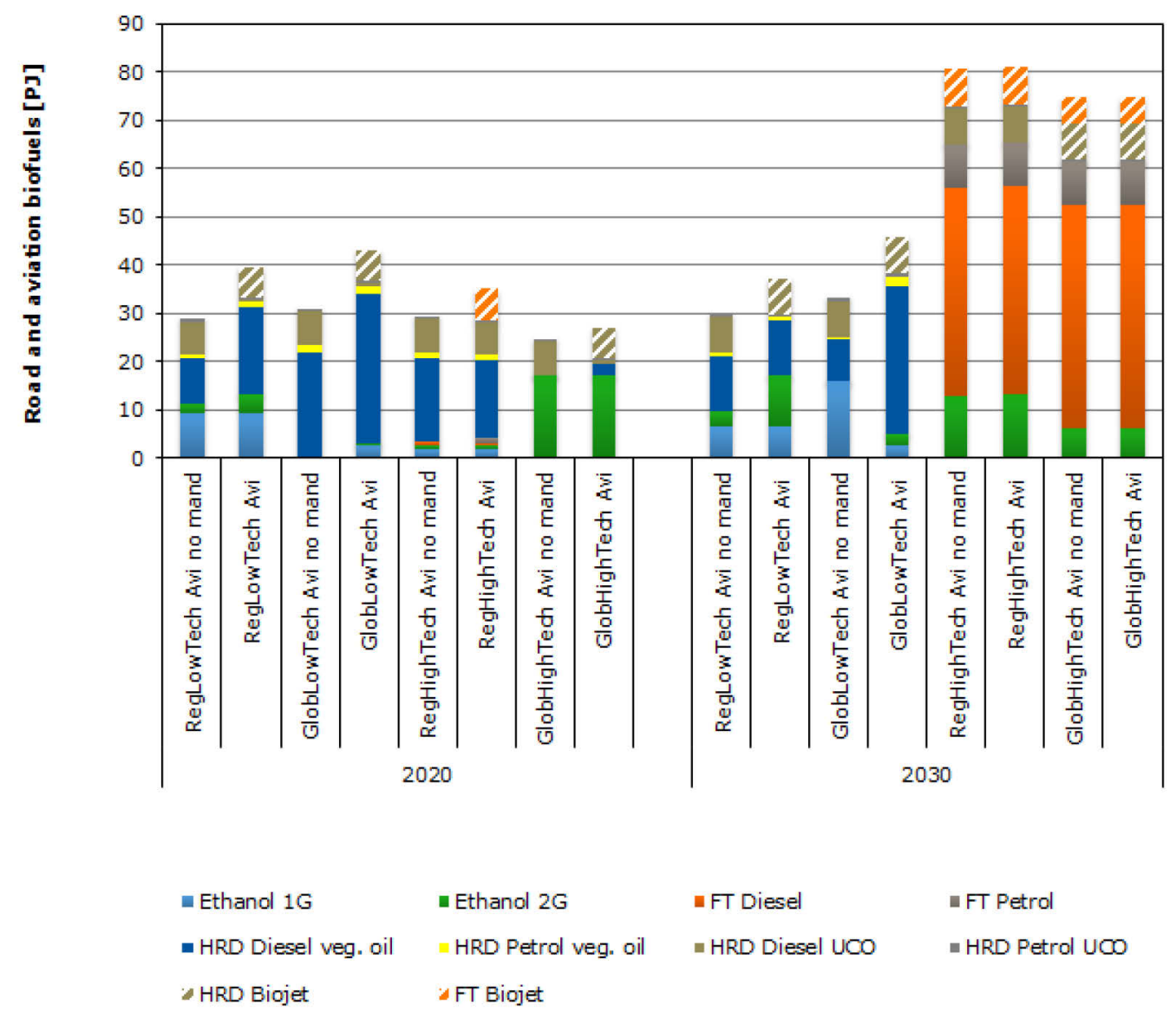

Figure 75 Road transport and jet biofuel mix in the Netherlands in 2020-2030 when the aviation sector is included in the energy system with (Avi) and without a blending mandate (Avi no mand)

When a blending mandate is introduced from 2020 onwards, biojet is supplied cross all scenarios. The key findings are:

- In low technology development scenarios, biojet is supplied from hydrotreated used cooking oil in 2020 and 2030, while in regional high technology development scenarios FT biojet is the principal supply; at the same time, larger quantities of ethanol are supplied to the road transport sector as used cooking oil has been redirected to the aviation sector.

- In GlobHighTech scenarios with and without blending mandate, both FT biojet and HRD biojet are supplied to the aviation sector and the blending target is exceeded.

Table 24 presents the biofuel share over the total fuel consumption (final energy) in road and aviation sectors across the different scenarios and time periods. Note that the aviation sector is not incorporated in the EU RED renewable energy share. 
Table 24

Biofuel share in road transport and aviation sector across different scenarios (no double-counting of biofuels produced by waste biomass)

\begin{tabular}{|c|c|c|c|c|}
\hline & \multicolumn{2}{|c|}{2020} & \multicolumn{2}{|c|}{2030} \\
\hline RegLowTech Avi no mand & $7.5 \%$ & $0.0 \%$ & $7.2 \%$ & $0.0 \%$ \\
\hline GlobLowTech Avi no mand & $8.1 \%$ & $0.0 \%$ & $8.1 \%$ & $0.0 \%$ \\
\hline GlobLowTech Avi & $9.6 \%$ & $3.8 \%$ & $9.3 \%$ & $3.8 \%$ \\
\hline RegHighTech Avi & $7.5 \%$ & $3.8 \%$ & $17.9 \%$ & $3.9 \%$ \\
\hline GlobHighTech Avi no mand & $6.4 \%$ & $0.0 \%$ & $15.1 \%$ & $6.6 \%$ \\
\hline GlobHighTech Avi & $5.4 \%$ & $3.8 \%$ & $15.1 \%$ & $6.6 \%$ \\
\hline
\end{tabular}

\subsubsection{Reduced demand for chemicals}

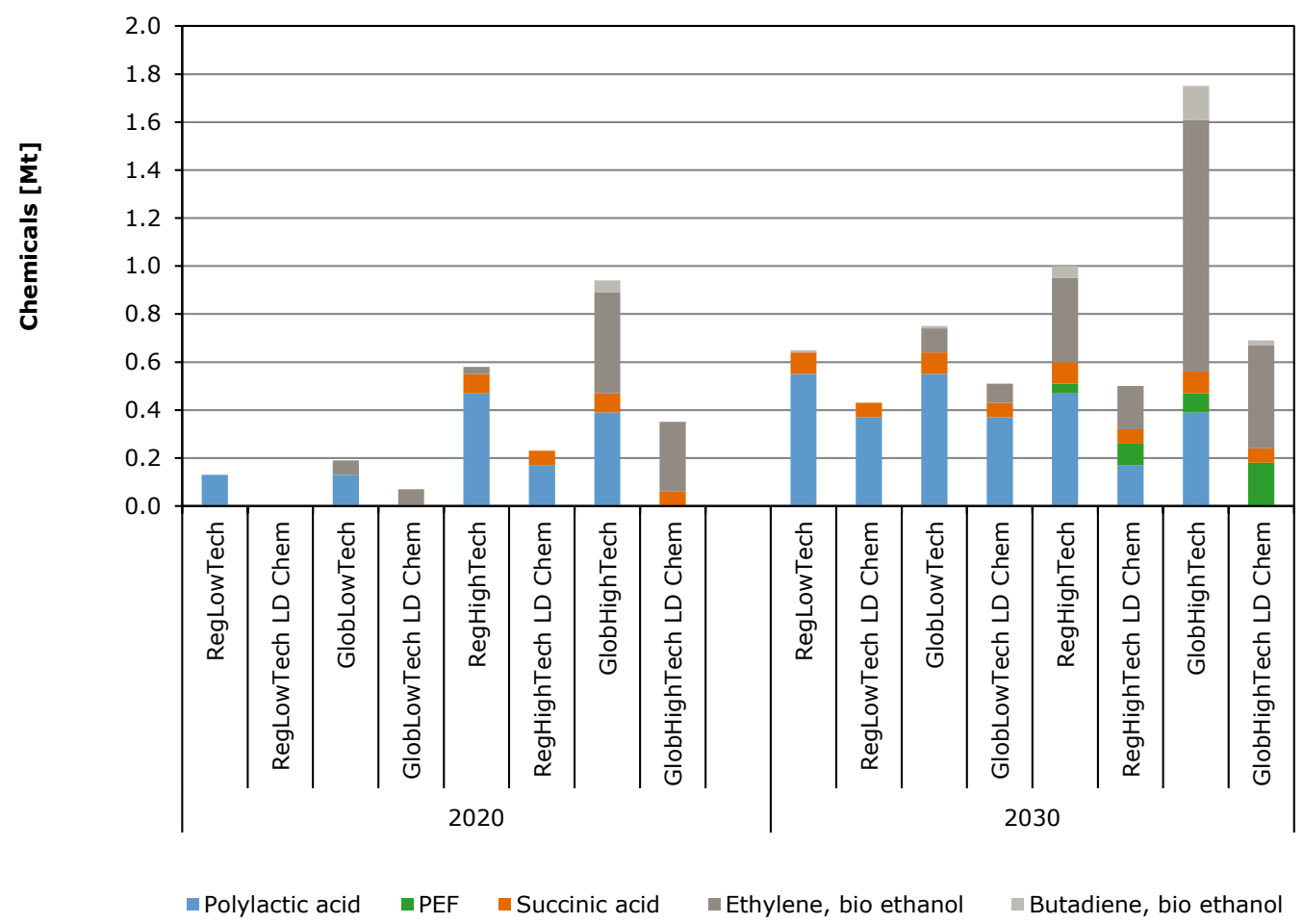

Figure 76 Bio-based chemical output in the Netherlands in 2020-2030 assuming decrease in demand(LD Chem) in comparison with reference results.

- Assuming a $10 \%$ decrease in demand for chemicals has a great effect on bio-based chemical output: low technology development scenarios have no output by 2020 , while there is a decrease of $60 \%$ in bio-based chemicals output in high technology development scenarios.

- By 2030, compared to the reference scenarios the output of bio-based chemicals decreases by $30 \%$ in low technology development scenarios and by $50-60 \%$ in high technology development scenarios.

- In most scenarios, PLA and ethylene from ethanol remain key chemicals, with one exception: in high technology development scenarios, open access to biomass markets favours the production of PEF as opposed to PLA.

- The decrease in biomass consumption levels (primary energy) is in the range of $3-10 \%$ compared to reference scenarios. 


\subsection{Top-down MAGNET sensitivity analyses}

In this section we present the sensitivity analyses on key assumptions performed with the top-down MAGNET model. Section 5.2.1 presents the analyses of the impact of lower fossil fuel prices and Section 5.2.2 describes the results of the $40 \% \mathrm{CO}_{2}$ reduction target in the Netherlands. Agriculturerelated sensitivities are treated in Section 5.2.3 and Section 5.2.4. The former concerns the impact of higher technological change in agriculture, the latter the impact of lower sugar prices.

\subsubsection{Fossil fuel prices}

The price of fossil energy is a key assumption in and determinant of bioeconomy developments. However, the future fossil energy prices are very uncertain. In the main MEV II scenarios, we use the most recent IEA fossil energy projections to 2030 (e.g. $€ 124$ per barrel for crude oil). This price is high given current low oil prices of $€ 35-40$ per barrel. Expectations are that oil prices will increase again. To cover this uncertainty, $50 \%$ lower fossil prices than in the main MEV II scenarios are assumed. With $50 \%$ lower fossil energy prices, most bio-based products are not competitive.

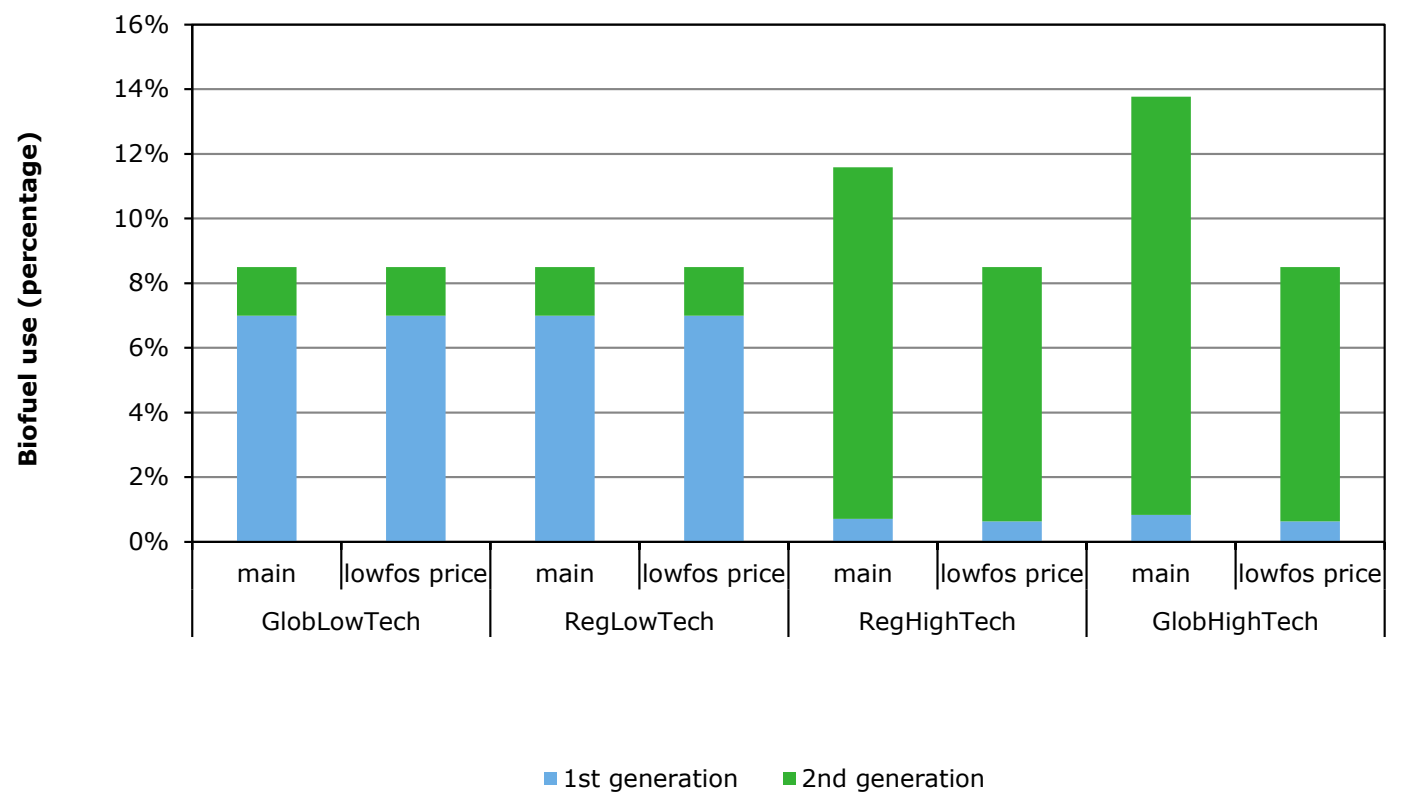

Figure 77 First- and second-generation biofuel shares in 2030 (-50\% of reference fossil fuel price) Main = one of the 4 main MEV II scenarios, lowfos price = low fossil energy price scenario

Figure 77 shows that with lower fossil energy prices biofuels are fully determined by the mandate level in all scenarios. Biofuels are no longer competitive with their fossil substitutes and biofuel shares are equal to the mandate of $10 \%$ biofuels ( $\max .7 \%$ first-generation biofuels and $\min .1 .5 \%$ secondgeneration biofuels, which count double). Second-generation biofuels are competitive in the high technology scenarios relative to first-generation biofuels, and the mandates will be filled with secondgeneration biofuels, while they were filled with first-generation biofuels in the low technology scenarios. So, overall one can conclude that with low fossil energy prices, the biofuel share will be determined by the mandate specified in the biofuel policy and the biomass used is determined by the rate of technical change. In the case of high technological changes, second-generation biofuels will be used; otherwise first-generation biofuels will be used. 


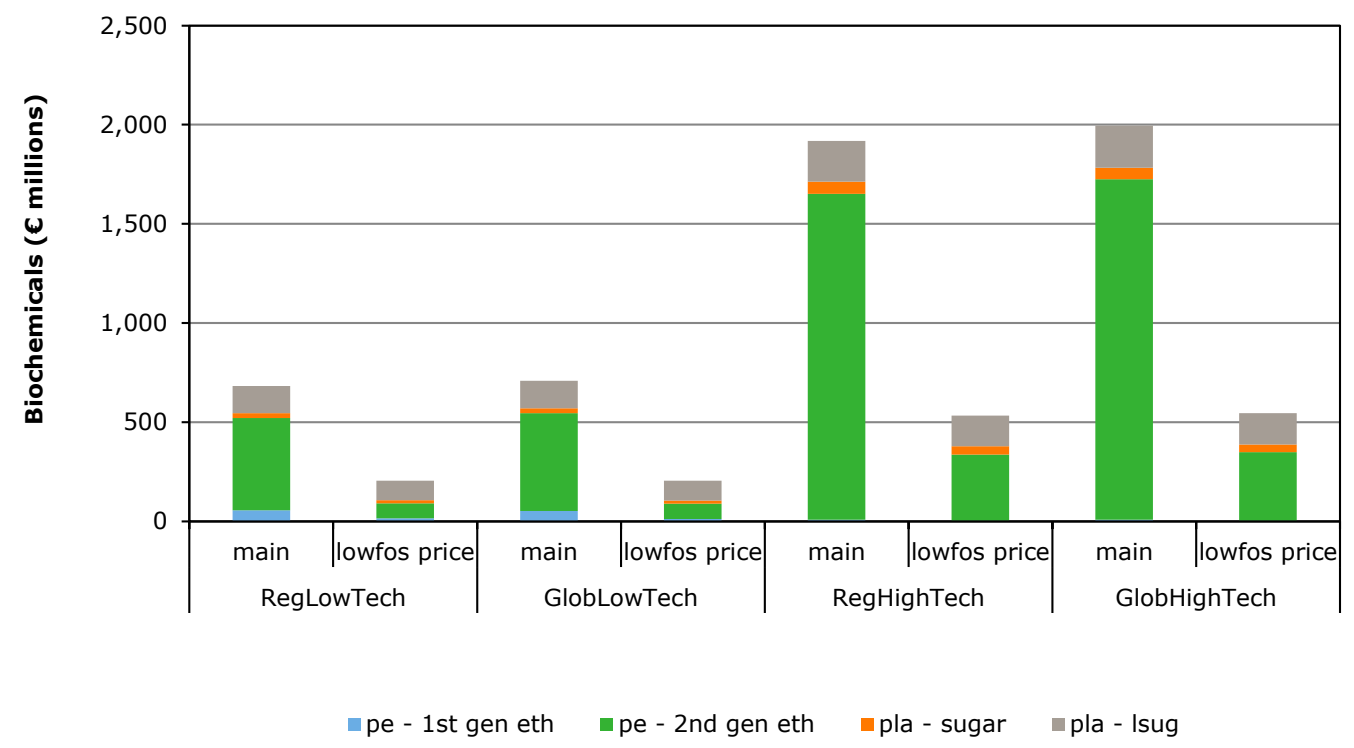

Figure 78 Production of bio-based chemicals in 2030 ( $€$ millions, -50\% of reference fossil fuel price)

Figure 78 shows that with a lower fossil energy price, the production of bio-based chemicals is substantially lower but does not stop. With low energy prices and low technological change, hardly any bio-based chemicals are produced. With high technological change, over $€ 500 \mathrm{~m}$ of bio-based chemicals are still produced. Apparently, biochemicals based on ethanol to chemicals (e.g. polyethylene) decline relatively more due to lower fossil fuel prices than do biochemicals based on sugar to chemicals (e.g. PLA).

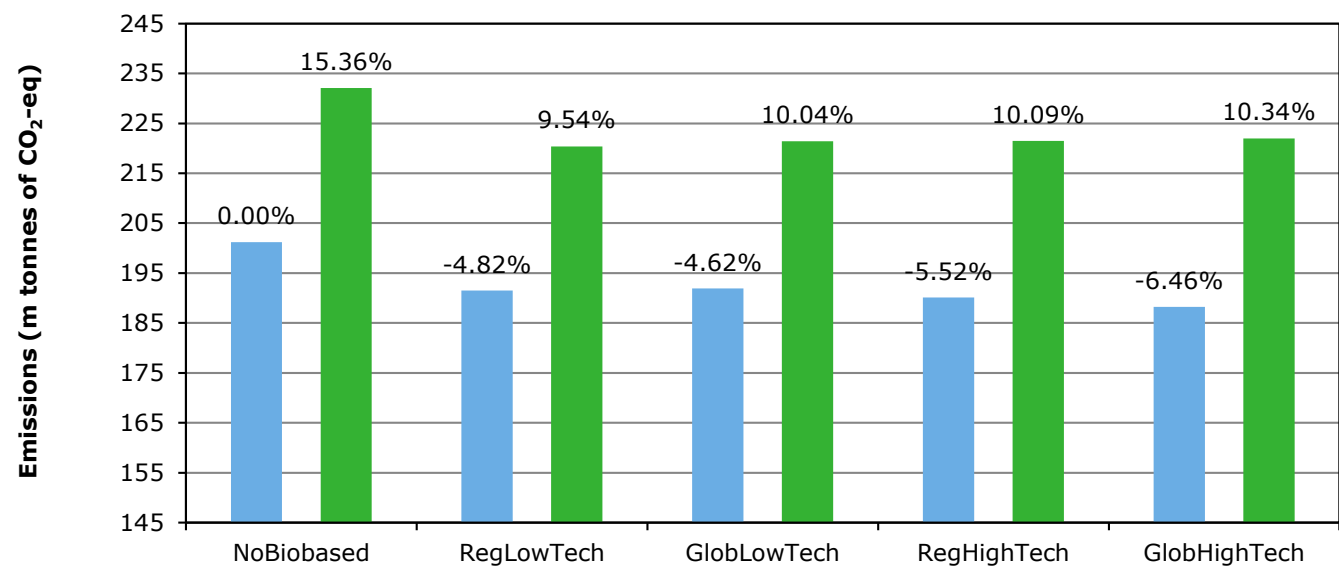

main low fossil price

Figure 79 Total emissions in the Netherlands in 2030 (million tonnes of $\mathrm{CO}_{2}$ eq, -50\% of reference fossil fuel price)

Figure 79 shows that GHG emissions increase due to low fossil prices as energy demand increases and bio-based products replace fewer fossil-based products. Without the bioeconomy (NoBioBased) GHG 
emissions will be $15 \%$ higher than with the higher fossil energy price in the MEV II main scenarios. Introducing RED policies reduces this to about $10 \%$ in all scenarios. Differences between scenarios are limited as the bioeconomy hardly develops outside the RED policy. It is clear that current $\mathrm{CO}_{2}$ taxes are not sufficient to keep emissions constant at current level with low fossil prices. Much higher $\mathrm{CO}_{2}$ taxes are needed with low fossil fuel prices to keep emissions constant.

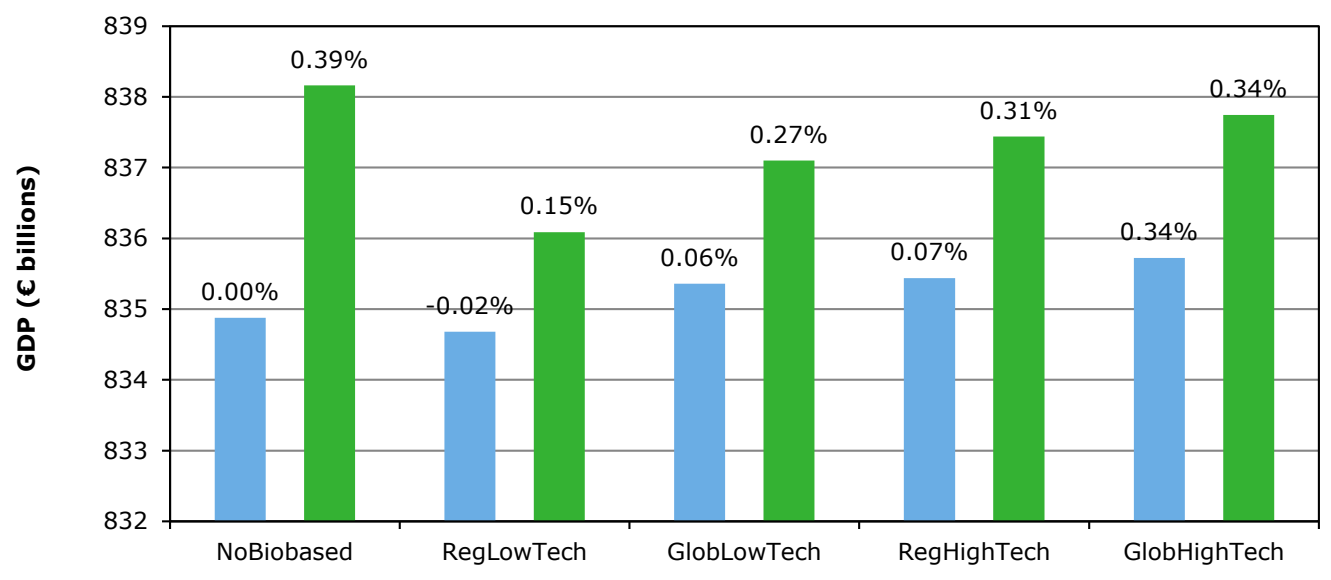

main low fossil price

Figure 80 GDP Netherlands (2030, € millions) for main MEV II scenarios and -50\% of reference fossil fuel price

Figure 80 shows the GDP impact in the Netherlands in 2030. Lower fossil energy prices have a positive impact on Dutch GDP as oil imports get cheaper. In the NoBioBased scenario, the positive impact is greatest $(0.4 \%)$. The introduction of the energy directives has a negative impact on GDP relative to the NoBioBased scenario, as the bio-based technologies are not competitive with their fossil-based counterpart. The positive impact on GDP drops to $0.15 \%$. Introducing open global biomass markets and high technological change in bio-based technologies increases this effect to $0.34 \%$.

\section{Key message}

Lower fossil energy prices reduce the bioeconomy to the level set in RED policies. Biochemicals almost disappear. High technological change implies only that first-generation technologies are substituted by second-generation technologies. GHG emissions will be much higher and current $\mathrm{CO}_{2}$ taxes are insufficient to keep emissions at current levels. GDP effects will be positive due to low fossil energy prices. Open markets and high technological change in bio-based technologies reduce the negative impact.

\subsection{2 $\mathrm{CO}_{2}$ tax and emission reduction targets}

In the main scenario analyses, we assume an $\mathrm{EU}$-wide $\$ 36$ per tonne $\mathrm{CO}_{2}$ tax to achieve the EU emission targets (IEA 2015). In this sensitivity scenario, we assume that the $40 \%$ emission reduction has to be achieved within the Netherlands. The key characteristics are:

- GHG emission reduction target of $40 \%$ has to be fully met within the Netherlands.

- Part of the reduction is fulfilled by CCS, which is not explicitly modelled in the MAGNET model. We assume in MAGNET that, based on results of MARKAL-NL-UU, 16\% of the GHG emission reduction is fulfilled by CCS. So in this sensitivity analyses GHG emissions are not reduced by $40 \%$ but with the remaining $24 \%$ reduction in GHG emissions. A shortcoming of this assumption is that costs related to CCS are not taken into account. 
- WARNING: Even the $24 \%$ GHG emissions reduction in the Netherlands stretches this model to its limit and results have to be interpreted with care. Only general tendencies should be taken into account.

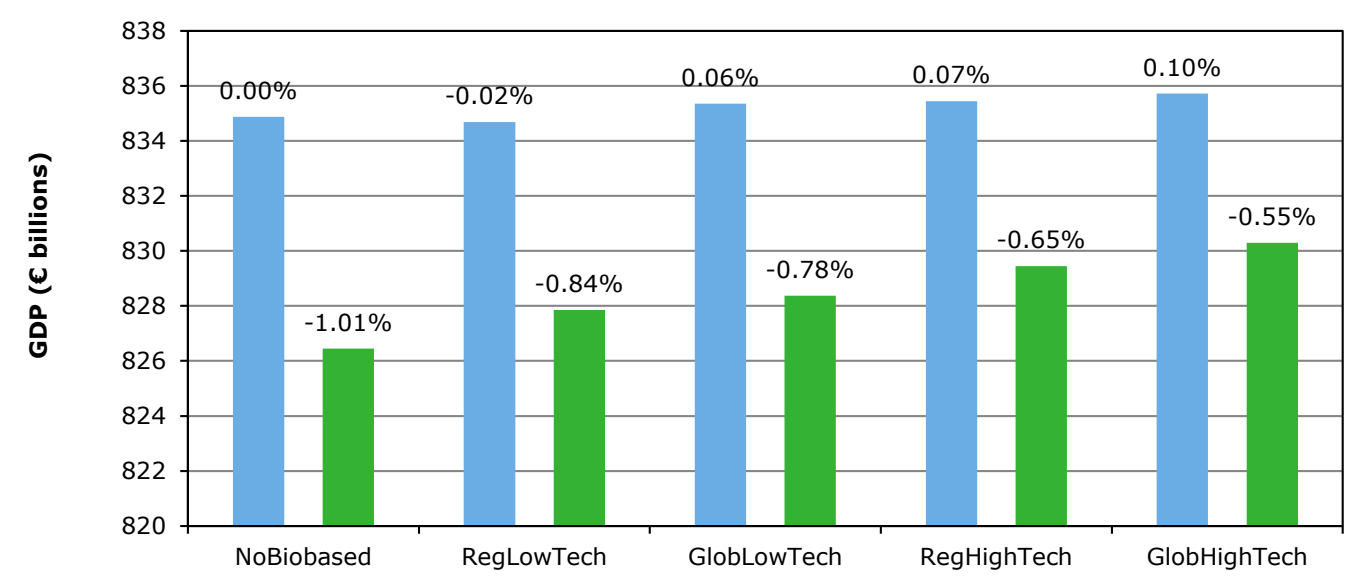

main amission reduction

Figure 81 GDP Netherlands (2030, € billions) for scenarios with $\$ 36 /$ tonne and $40 \%$ emission reduction target.

Main = one of the four main MEV II scenarios; emission reduction $=24 \%$ GHG emission reduction in the Netherlands by $\mathrm{CO}_{2}$ taxes ( $16 \%$ reduction assumed outside mode by CCS).

- Figure 81 shows that a $24 \%$ emission reduction compared to $\$ 36 /$ tonne $\mathrm{CO}_{2}$ tax costs about $1 \%$ of GDP without the bioeconomy (NoBioBased scenario). The costs in terms of GDP are lower if biomass markets are global and technological change is higher in the bio-based technologies. Reducing emissions to $24 \%$ in the Netherlands costs between $0.55 \%$ and $1.01 \%$ of GDP.

- The RegLowTech scenario even has a positive GDP effect compared to the NoBioBased scenario equal to $0.17 \%$. Due to high $\mathrm{CO}_{2}$ taxes, bio-based technologies become more competitive with their fossil substitutes and are important to reduce GHG emissions. With the lower $\mathrm{CO}_{2}$ taxes, the RegLowTech scenario has a negative GDP effect compared to the NoBioBased scenario.

- Opening biomass markets or introducing technological change within the bioeconomy increases the GDP effects, as we saw in the main MEV II scenarios. However, the positive impact on GDP in \% points is much higher. In the global high technology scenario the costs of reaching the GHG target is almost $0.5 \%$ of GDP less than in the NoBioBased scenario. Especially the HighTech dimension is important for this positive GDP effect.

Most of the emission reduction is achieved by using wind energy instead of gas and coal energy. Figure 82 shows that part of the emission reduction is done by switching to biofuels. This switch mainly occurs in the global high technology scenario. In the regional high technology scenario, the biomass is too expensive to increase the use of biofuels significantly. In the LowTech scenarios, biofuels remain too expensive despite the higher $\mathrm{CO}_{2}$ tax.

Finally, there is no significant increase in the use of biochemicals due to the emission reduction targets. However, the use of fossil chemicals decreases significantly $(-13 \%)$. This leads to a declining chemical sector and an increasing share of bio-based chemicals within total chemicals.

\section{Key message}

Wind energy that substitutes for gas and coal makes the greatest contribution to achieving a $24 \%$ reduction in GHG emissions compared to a $\$ 36 /$ tonne $\mathrm{CO}_{2}$ tax. The $24 \%$ target costs about $1 \%$ of GDP 
in the NoBioBased scenario. The costs in terms of GDP decline if biomass markets are global and especially if technological change is higher in the bio-based technologies. Global markets together with high technological change reduce the reduction in GDP by $0.5 \%$ relative to the NoBioBased scenario. However, these results have to be interpreted with care, as these scenarios stretch the model to its limit as all kinds of potential substitutional effects might not be taken into account.

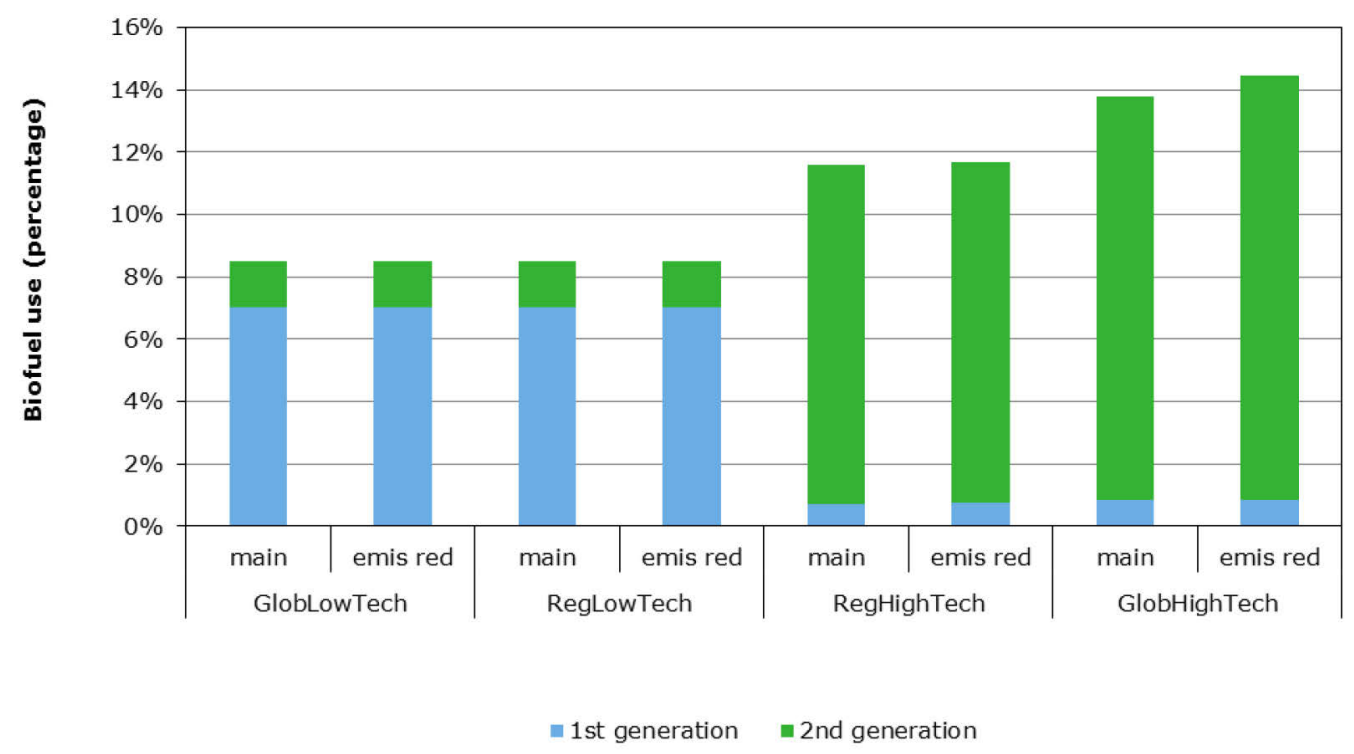

Figure 82 First- and second-generation biofuel shares in 2030 for scenarios with \$36/tonne and $40 \%$ emission reduction target

\subsubsection{Higher technological change in agriculture}

In the main scenarios, we assume only additional technological change in the bio-based fuel and chemical technologies and nothing in the agricultural sector, which is a main sector within the bioeconomy complex. This section presents a sensitivity analysis with regard to technological investments and change in the primary biomass producing sectors. More specifically, we assume a $10 \%$ yield increase in all primary crop sectors and forestry only in the two high technology scenarios. The results for the low technology scenarios are therefore identical for the main and additional yield scenarios.

Figure 83 shows that GDP levels in $€$ billions in 2030 are higher due to technological change in the primary agricultural and forestry sectors in the HighTech scenarios. The GDP impact of a relatively small yield increase (10\%) in the GlobHighTech scenario is equal to $0.3 \%$ of GDP and therefore higher than the $0.12 \%$ in the corresponding MEV II scenario. The impact is so large because primary crop sectors and forestry are relatively substantial in size, and especially the crop sectors are quite export oriented. Higher yields lead to lower prices and therefore a better competitiveness of Dutch primary crop sectors (farmers and horticulture). Furthermore, a yield increase can be seen as an increase in the availability of land in efficiency units, and this is different from the case where bio-based activities substitute for fossil energy activities and production factors are more or less constant. 


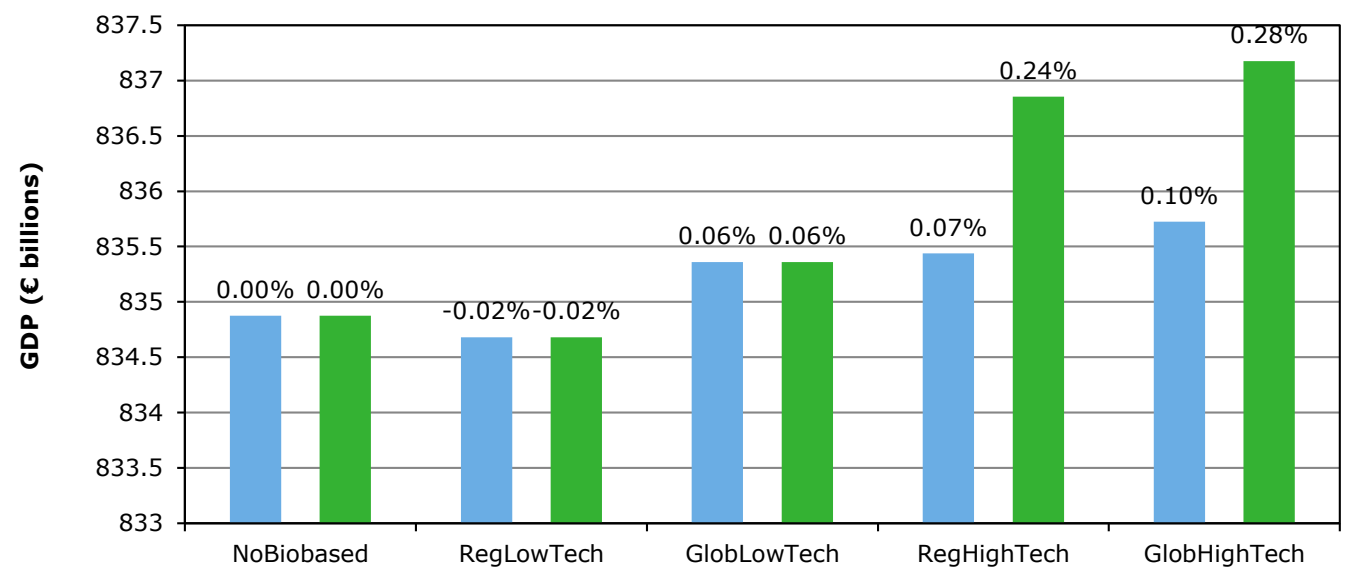

main agri shock

Figure 83 GDP Netherlands (2030, € billions) for the main MEV II scenarios with or without $10 \%$ additional yields in Dutch crop and forestry sectors.

Main = one of the four main MEV II scenarios; agri shock = a $10 \%$ yield increase in all primary crop sectors and forestry.

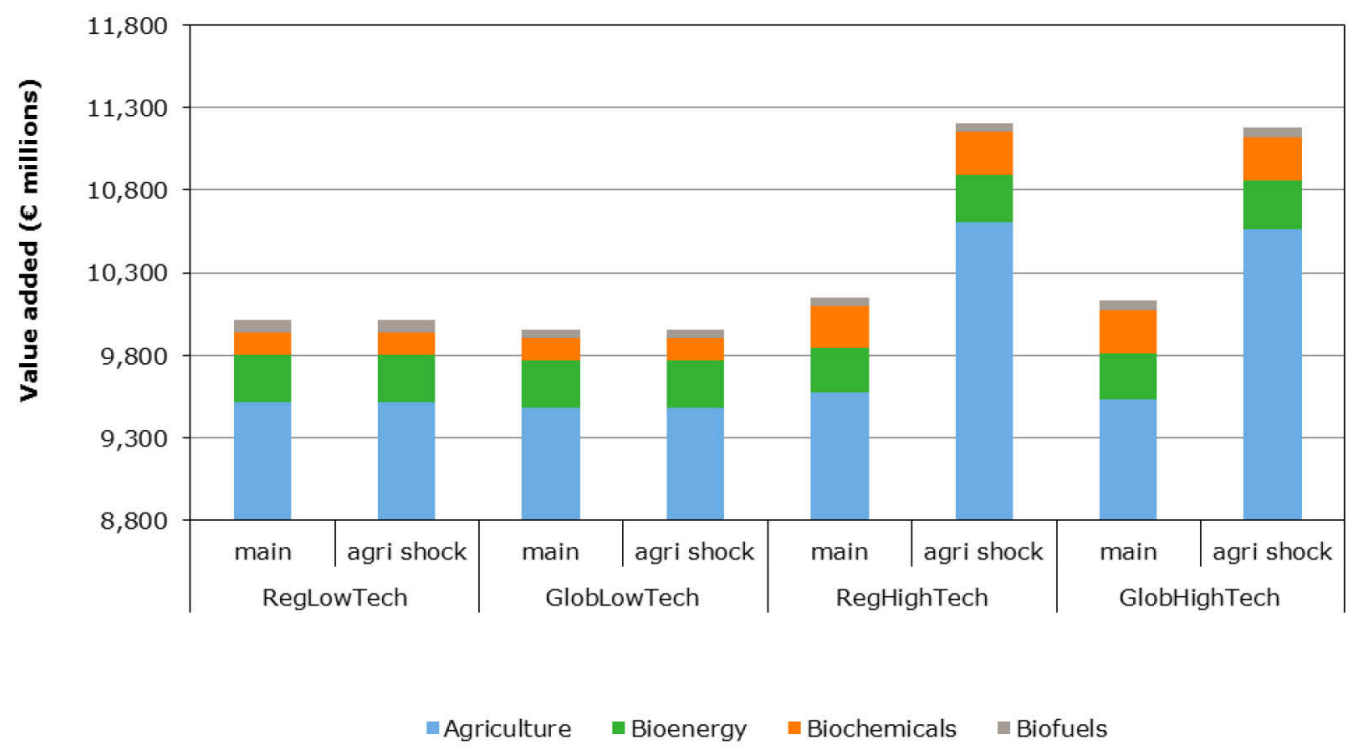

Figure 84 Value added of bioeconomy sectors (2030, € million) for the main MEV II scenarios with or without $10 \%$ additional yields in Dutch crop and forestry sectors

Figure 84 shows that value added increases by $€ 1$ bn in the global HighTech scenario in the bioeconomy. Value added changes mainly in the agricultural sectors and just a little in the biofuel, bioelectricity and bio-based chemical sectors. The direct effect on agricultural sectors is much more important for value added than the indirect effects on other bioeconomy sectors. Value added increase is high because the Netherlands has a strong competitive advantage in agri-food sectors and additional technological change increases the competitiveness even more. As agricultural markets are quite competitive and the Netherlands is a small country, world prices do not decline too much due increased production in the Netherlands. The production increase in the Netherlands leads to more 
exports against a moderate price decline. The new bioeconomy sectors do not profit a lot, as they do not source much from Dutch primary agricultural products and also because primary agricultural prices do not decrease a lot. The two figures below show that extra available biomass is used in both the biofuel and the biochemical sector, although the impact of the extra biomass is minimal.

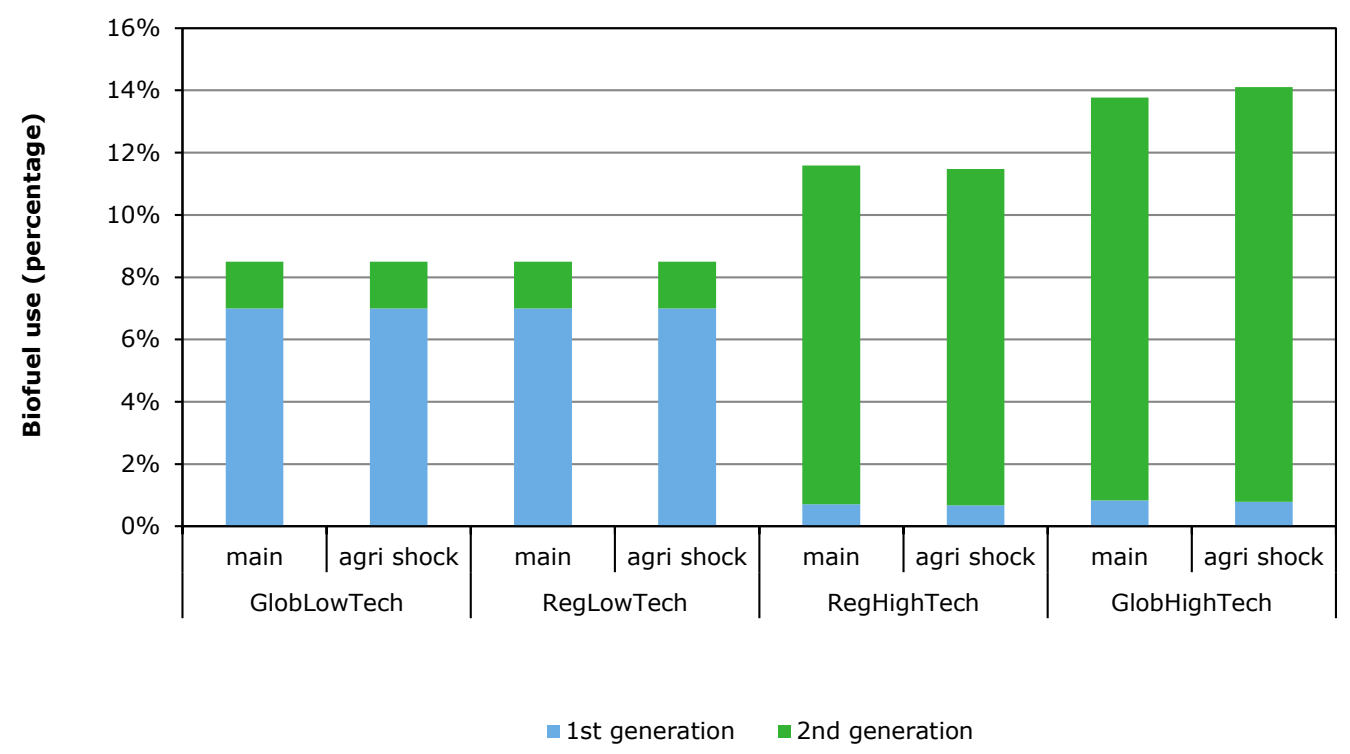

Figure 85 First- and second-generation biofuel shares (2030, € millions) for the main MEV II scenarios with or without $10 \%$ additional yields in Dutch crop and forestry sectors

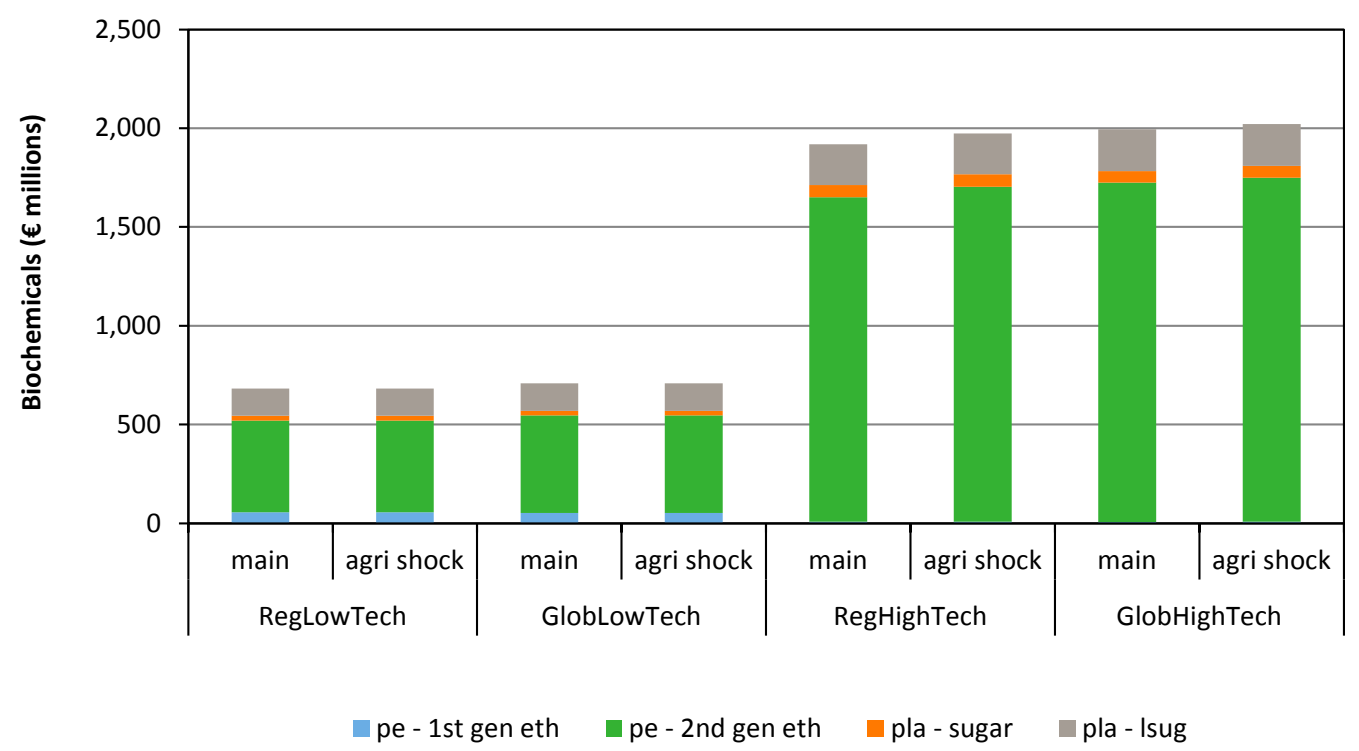

Figure 86 Production of bio-based chemicals (2030, € millions) for the main MEV II scenarios with or without $10 \%$ additional yields in Dutch crop and forestry sectors

\section{Key message}

Higher yields in primary sectors such as agriculture and forestry lead to significant positive GDP effects as especially the export oriented agri-food industries can increase their market share without having to decrease their price levels too much. The indirect benefits for the new bioeconomy sectors 
are limited as these sectors source only a small share from domestic agricultural primary products and feedstock prices on a global level do not decline a lot.

\subsubsection{Lower sugar prices}

In this section, we present a sensitivity analyses with regard to the sugar price, as this is considered an important domestic feedstock.

The 'sugar shock' scenario combines a $30 \%$ yield increase in the sugar beet sector with a $20 \%$ price decrease in conventional sugar.

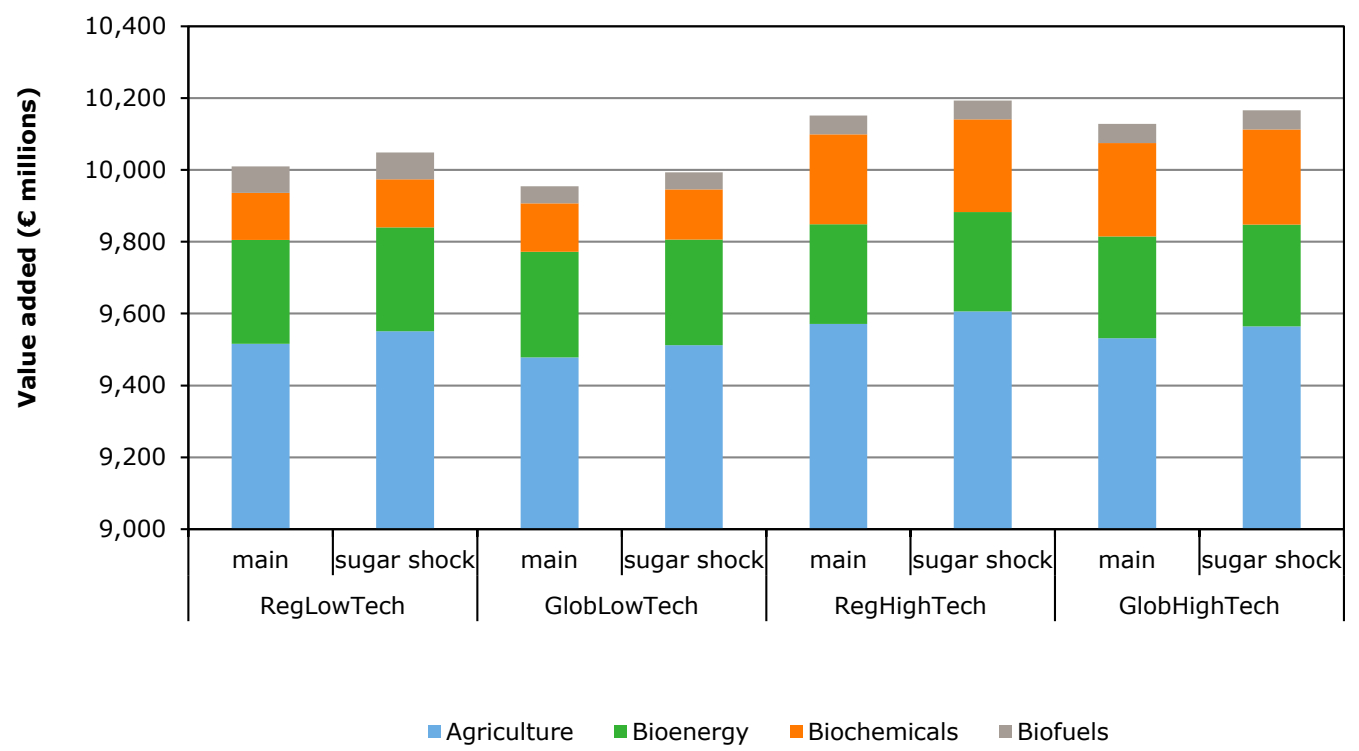

Figure 87 Value added of bioeconomy sectors (2030, $€$ millions) for scenarios with lower sugar prices and increased yields in the sugar beet sector.

Main = one of the four main MEV II scenarios; sugar shock = 30\% yield increase in the sugar beet sector with a $20 \%$ price decrease in conventional sugar.

Figure 87 shows that due to the sugar shock, the value added in the bioeconomy and especially the agricultural sector increases. Due to the lower sugar price, the value added in bio-based chemicals and to a lesser extent biofuels also increase. The increase in the agricultural (especially sugar sector) is about $€ 34 \mathrm{~m}$ and the increase in the bio-based chemicals is $€ 5-8 \mathrm{~m}$. The increase in the bio-based chemical sector is highest in the RegHighTech scenario, where bio-based products are relatively competitive and biomass sources are most constraint. 


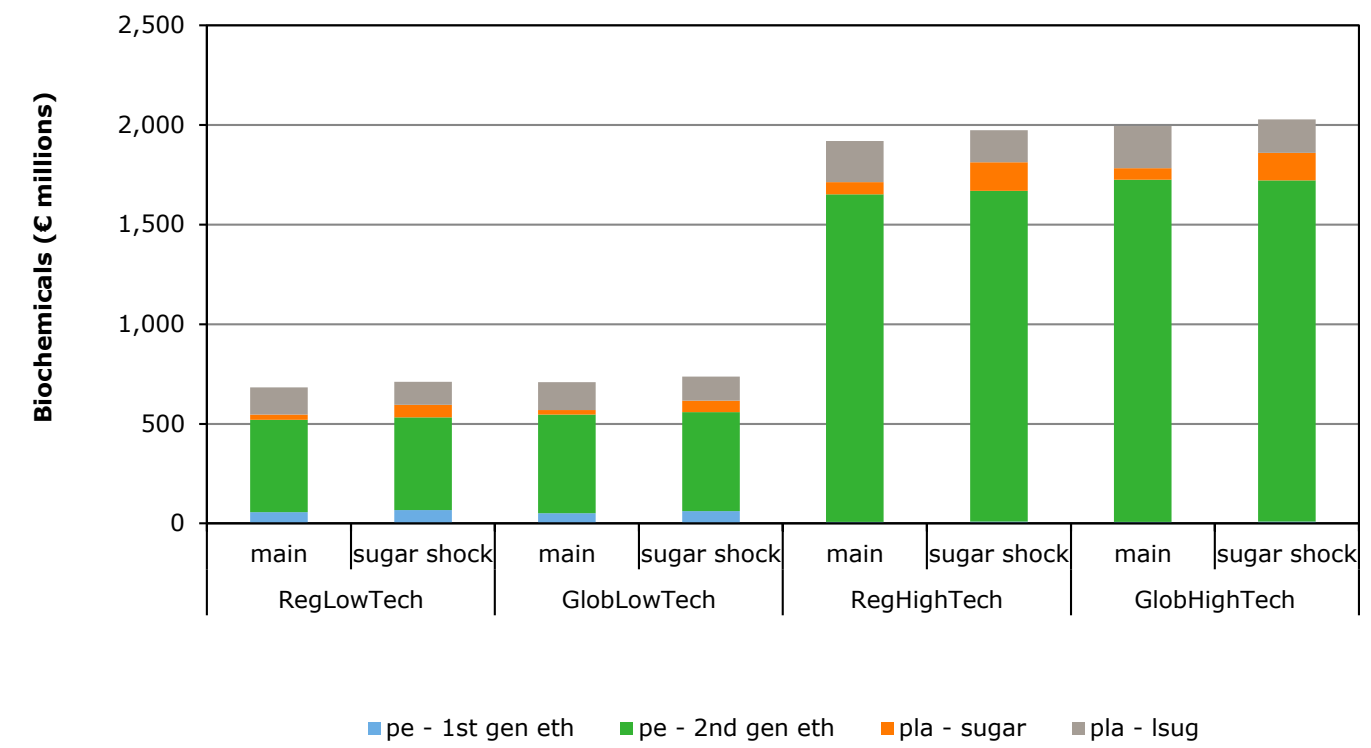

Figure 88 Production of bio-based chemicals (2030, € millions) for scenarios with lower sugar prices and increased yields in the sugar beet sector

Figure 88 shows that due to the sugar shock, bio-based chemicals increase. In the regional and global high technology scenarios, the sugar shock induces more PLA from sugar, which in this scenario is more competitive with PLA based on lignocellulosic sugar, which sees a high technological change in the HighTech scenarios.

\section{Key message}

Higher yields in the sugar beet sector and lower sugar prices increase value added by $€ 34 \mathrm{~m}$ in the bioeconomy and especially the sugar sector. Due to the lower sugar price, the value added in biobased chemicals ( $€ 5-8 \mathrm{~m})$ and to a lesser extent biofuels also increase. 


\section{Discussion}

\subsection{Outcome compared to MEV-I}

The Macroeconomic outlook of sustainable energy and biorenewables (MEV II) study is the successor to the macroeconomic study conducted in 2007-2008 (MEV I). Both MEV I and MEV II assessed the possible impacts at system level and macroeconomic level of pursuing a bio-based economy in the Netherlands to 2030 under different scenarios of technological development and openness of international biomass markets. A comparison of the two studies led to the following observations.

\section{Less difference across MEV II scenario results compared to MEV I scenario results}

There are three main reasons for this:

- Technology progress in and outside the Netherlands has followed a LowTech scenario pathway in the last 5 years. ${ }^{21}$ This means that in the MEV II HighTech scenarios, actual technology progress is delayed compared to what was assumed in the MEV I study to 2015.

- The policy ambitions assumed in the two studies are very different. The MEV I study assessed the ambition to substitute as much as $30 \%$ of primary energy demand in the Netherlands by biomass in 2030 , with a minimum blending share of biofuels in transport of as much as $60 \%$ in the GlobHighTech scenario in 2030. In the MEV II study, a share of about $13 \%$ in road transport in the GlobHighTech scenario in 2030 is an outcome of the analyses.

- The MEV II study addressed better competition with other renewable energy sources (mainly wind and PV) and included, in contrast to MEV I, the option to capture and store $\mathrm{CO}_{2}$ (CCS). This led to more balanced deployment pathways of renewable energy compared to the predefined biomass technology deployment scenarios of MEV I.

As a result of the above, lower bio-based shares are projected in the MEV II scenario than in the MEV I study, especially in the HighTech scenarios. As mentioned, the share in road transport in the GlobHighTech scenario is not $60 \%$, but $13 \%$. For the electricity sector, the biomass share assumed in the GlobHighTech scenario in MEV I was $29 \%$ while the endogenous outcome in MEV II is $4 \%$ in the bottom-up analyses and $9 \%$ in the top-down analyses. For the chemical sector MEV I assumed $19 \%$ in the GlobHighTech scenario, while the endogenous outcome in MEV II is $9 \%$ in the top-down model.

More ambitious policy scenarios with respect to GHG mitigation were assessed in the sensitivity analysis of the MEV II study. The renewable energy share increases to $17-27 \%$ in order to meet ambitious GHG reduction targets (up to $40 \%$ by 2030). Furthermore, CCS contributes substantially to these targets. Between 25 and $40 \mathrm{mt}$ of $\mathrm{CO}_{2}$ are captured and stored in these scenarios by 2030 . The most optimistic scenario in MEV I estimates a GHG saving of $53 \mathrm{mt}$ of $\mathrm{CO}_{2}$ eq by 2030 without CCS and wind power, but requires very large amounts of biomass (up to 1,410 PJ in 2030 under the GlobHighTechAC scenario, equivalent to $80 \mathrm{mt}$ of wood pellets), the majority of which has to be imported (Hoefnagels et al., 2013).

\section{MEV II reconfirms the main conclusions of the MEV I study}

Although the magnitude of biomass deployment for energy and materials is differs between the MEV I and the MEV II study, both studies show that the use of biomass for energy and chemicals can have positive synergetic effects on reducing GHG emissions, increasing energy security and generating

\footnotetext{
${ }^{21}$ See for example TKI BBE Onderzoeksagenda Biobased Economy 2015 - 2027 'B4B: biobased voor bedrijven, burgers en beleid'
} 
economic activities in the agriculture, chemical and energy sectors of the Netherlands. The preconditions to achieve these synergy effects are similar in both studies and include:

- The need for strong technology development and the availability of international sustainable biomass sources.

- A shift from food-based production to non-food lignocellulosic feedstocks.

- Accelerated development of efficient production systems, in particular multi-output biorefineries that produce energy (electricity, heat, transport fuels) and chemicals via both thermochemical and biochemical conversion routes.

\subsection{Scenarios and scope}

\section{Temporal scope}

The MEV II study assessed the potential impacts of the bioeconomy to 2030. This choice is justified on the grounds that policies in the Netherlands and the EU set targets for 2020 regarding the renewable energy share, biofuel blending, emission reduction and similar ambitions for 2030. This led to more narrowly defined scenarios regarding technology development, biomass supply, etc., which offers some degree of certainty for the impacts of bioeconomy at a system and macroeconomic level. For example, the technology portfolio includes conversion options that are already commercialized or are likely to be by 2030 .

However, a direct implication of this limited time-horizon is that it does not provide insights into the potential role of the bioeconomy in the longer term. Technologies can become more competitive as they can benefit further from economies of scale. In addition, the technology portfolio relevant for the period beyond 2030 includes options that are currently in early stages of development, but can become commercial beyond 2030. Such options could influence conclusions as to the magnitude of the bioeconomy impact and, in general, different insights can be gained by extending the analysis to, for example, 2040 or 2050 . Nevertheless, an uncertain policy scenario beyond 2030 in combination with less robust insights into the techno-economic performance of technologies that are currently in the early stages of $R \& D$, would substantially increase the uncertainties of modelling results for the timeframe beyond 2030. Lastly, the MEV II assessment has already demonstrated the impact that uncertain exogenous parameters may have on outcomes, such as fossil fuel prices and $\mathrm{CO}_{2}$ tax levels, which in many cases were shown to be more influential than the uncertainty that the four reference scenarios aim to capture.

\section{Long-term improvements in value added of bio-based product value chains}

The results show that, similar to the MEV I study, new bio-based materials are mainly bulk type biopolymers. There is, however, substantial potential to further develop bio-based product value chains. Although many innovative concepts may not become commercially available before 2030, the development of these concepts is key to realizing a highly ambitious bio-based economy whilst minimizing financial support in the long term. These include:

- Lignin, which is produced during the processing of lignocellulosic biomass into fermentable sugars, is now assumed to be used for energy (heat, electricity). It could, however, also be used for the production of high value fuels (e.g. biojet fuels) as well as supramolecular materials and aromatic chemicals. These could improve significantly the performance of a lignocellulosic biorefinery (de Jong et al., 2012). ${ }^{22}$

- By maintaining the structure of amino acids and avoiding the energy-intensive process of nitrogen bonding that is needed for the petrochemical route, nitrogen-based functionalized biochemicals are promising. Although the market volume of these chemicals is in many cases relatively small

\footnotetext{
${ }^{22}$ de Jong, E., Higson, A., Walsh, P., \& Wellisch, M. (2012). Bio-based chemicals value added products from biorefineries. IEA Bioenergy, Task42 Biorefinery.
} 
compared to bulk chemicals, the added value as well as GHG and fossil fuel savings could still be large (Scott et al., 2007). ${ }^{23}$

- The production of polyhydroxyalkanoates (PHA) from fermentation is another potential substitute for polymers (e.g. polyethylene). Although PHA are at an early commercial stage, they are believed to have a high growth potential and they may lead to significant emission reductions. However, like many other pathways of biomass to materials, their production costs are higher than those of other polymers (de Jong et al., 2012).

It is difficult to predict which type of concept might become successful in the long term, as several pathways are in a less advanced stage either due to high manufacturing costs compared to other alternatives (e.g. PHA) or because more R\&D efforts are required to bring the processes from lab to commercial scales (e.g. lignin-based chemicals). Furthermore, attention should be paid to prospective learning effects (e.g. yield or efficiency improvements, scales) of these processes in order to capture their future deployment potential, as these routes will compete in similar markets with existing fossil alternatives and biochemicals. To include such routes in systems analysis frameworks, such information needs to be publically available, as production costs and future improvement potentials are typically proprietary to the technology developers thus posing barriers to assessing their competitiveness in an integrated framework such as used in this study.

\subsection{Impact of policies and level playing field}

The MEV II assessment incorporated key policies (EU RED and main elements of the Dutch Energy Agreement) across all scenarios. These policies have a significant influence on sectoral and overall outcomes of the bioeconomy. It has been shown that they are a key driver for bioeconomy development in most of the scenarios, as only in one scenario (GlobHighTech) are targets exceeded. This can create technology lock-ins with consequent impacts on the macroeconomic level. For example, this has been demonstrated for the deployment of offshore wind, which is a key contributor in renewable electricity to 2030. Therefore, the role of wind energy and the electricity sector to 2030 in the Dutch energy system is strongly dependent on the support of this policy. At the same time, it is uncertain how other options would compete if a level playing field were assessed.

Similarly, the extension of the blending target for biofuels in the road transport fuel mix from 2020 to 2030 places the road transport sector at the forefront of bioeconomy development, especially under high technology development scenarios. However, as it has not yet been stipulated whether or not the blending mandate will be extended, the role of this sector and the respective conversion technologies that are an outcome of the MEV II assessment may differ.

Another influential parameter is the increase in the renewable energy share target for the Netherlands to $16 \%$ after 2023 . As this is a key driver in most scenarios, it should be noted that this parameter can influence the scale of technologies deployed and demonstrate synergies across sectors.

As the above elements do not create a level playing field on which all fossil and renewable options compete, the results should be interpreted from this perspective.

\subsection{Feedstock supply potential and sustainability}

The supply potential of domestic and EU biomass sources in this study was based on the IEE project Biomass Policies (Elbersen, 2015). In that project, the supply potential and cost of forest, agriculture and waste biomass was determined to 2030 at the regional level (NUTS2). However, the supply of

\footnotetext{
${ }^{23}$ Scott, E., Peter, F. \& Sanders, J., 2007. Biomass in the manufacture of industrial products--the use of proteins and amino acids. Applied microbiology and biotechnology, 75(4), pp.751-62.
} 
biomass is not fixed and can change substantially depending mainly on developments in agriculture management, crop choices, food demand ${ }^{24}$ and the political framework. The influence of assuming a predefined supply mix of biomass, cost and land allocation is discussed in more detail in the sensitivity analysis.

Assuming low domestic biomass supply practically halves the projections for biomass consumption found in the reference scenarios assuming if manure treatment through co-digestion is mandated. Assuming high domestic biomass supply does not lead to significant differences. Thus, high domestic biomass estimates lead to results that are comparable to the reference results of this study, whereas low domestic biomass potentials practically halve biomass consumption levels.

\section{EU solid biomass supply}

Similar to the cost and supply of biomass from domestic sources, this study used the Biomass Policies dataset for biomass supply from other EU countries. The potential available supply of biomass to the Netherlands from intra-EU resources was determined based on the share of the Dutch Total Primary Energy Supply over the European, which for 2010-2030 is estimated to be 4.7-5\%. This ultimately determines the bandwidth of biomass available to the Netherlands at a specific cost in the cost-supply curves as incorporated in MARKAL-NL-UU. However, there is no strict method that stipulates how regional biomass should be allocated to a country as more factors play role (note that in MARKAL-NLUU biomass availability is exogenously determined). Therefore, this bandwidth could be higher, which entails that more low-cost biomass from EU resources could be available to the Netherlands.

One of the key determining factors in the potential of biomass is the cost of transport to the Netherlands. Solid biomass production costs (roadside costs) from Eastern Europe were found to be the lowest across the EU for most of the feedstock categories (primary and secondary forestry residues, wood crops, perennial grasses). Roadside costs for solid biomass in Eastern Europe (weighted average of Eastern European countries) are in the range of $€ 1-3 / G]$. However, transport costs to the Netherlands add approximately $€ 6-8 / G]$, making the final cost of supply of solid biomass $€ 8-9.5 / G$, thus exceeding the cost of wood pellets from extra-EU sources. Therefore, across all feedstocks supplied from Eastern Europe at such cost prices, only primary and secondary forestry residues and wood from short rotation forestry are exploited to their full potential by 2030 (30 PJ, $12 \mathrm{PJ}$, and 8.4 PJ, respectively at $€ 9.3 / \mathrm{G}], € 9 / \mathrm{G}]$ and $€ 9 / \mathrm{GJ}$, respectively) and only in the regional scenarios. Primary forestry residues are only exploited in the RegHighTech scenario. When more advanced pre-treatment of solid biomass takes place in the country of origin (e.g. palletization, torrefaction, pyrolysis), the total cost of supply could be reduced as a result of reduced transport costs, and thus the Netherlands could be supplied with solid biomass at prices lower than $€ 9 / G]$.

\section{Extra-EU resources}

Solid biomass supply from extra-EU sources is assumed to increase to $400 \mathrm{PJ}$ (23mt of wood pellet equivalent) and remain constant between 2020 and 2030. In comparison, total wood pellet import to the EU-28 was $128 \mathrm{PJ}(7.5 \mathrm{mt})$ in $2014 .{ }^{25}$ In the Biomass Policies project, ${ }^{26}$ the total supply of extra-EU solid biomass available to the EU is projected to increase to $1233 \mathrm{PJ}(72 \mathrm{mt}$ ) in 2030 , which is roughly in line with projections made in other studies. ${ }^{27}$ In that case, the Netherlands takes about $1 / 3^{\text {rd }}$ of the total supply potential available to the EU. Although the Netherlands has favourable conditions for overseas imports, the supply potential might be considered optimistic. Note, however, that the potential is not exploited in the reference scenarios: only up to $103 \mathrm{PJ}(6 \mathrm{mt})$ is imported in the

\footnotetext{
24 Dornburg, V. et al., 2010. Bioenergy revisited: Key factors in global potentials of bioenergy. Energy Environ. Sci., 3, pp. 258-267.

25 Hoefnagels, R., Junginger, M. \& Resch, G., 2015. DiaCore - Coordination of biomass resource availability import strategies and demand, Utrecht (NL), Vienna (AT).

${ }^{26}$ Fritsche, U. \& Iriarte, L., 2014. Biomass Policies - Task 2.4: Sustainable Imports. Cost supply curves for medium- to longer-term potentials for sustainable biomass and bioenergy (pellets, biomethane, liquid biofuels) imports to the EU-27., Darmstadt, Madrid.

27 When available, results of the IEE project BioTrade2020+ will provide more insight into the sustainable export potential of solid biomass available to the EU. www.biotrade2020plus
} 
GlobHighTech scenario in 2030. Alternative scenarios, with high fossil fuel prices or high GHG reduction targets, will however increase the demand for imported biomass.

Liquid biofuels available for import to the Netherlands are assumed to increase to $50 \mathrm{PJ}$ in 2020 and remain constant to 2030 . A recent study by $E 4 T_{e c h}{ }^{28}$ estimates that the export potential available to the EU will increase to $371 \mathrm{PJ}$ and $900 \mathrm{PJ}$ in 2030 compared to $214 \mathrm{PJ}$ imported in $2012,{ }^{29}$ which would mean that $6-13 \%$ of extra-EU supply of liquid biofuels is available to the Netherlands depending on the scenario.

\section{Sustainability}

In all scenarios assessed, imported solid biomass and liquid biofuels play a key role. However, the production of biomass, regardless of its end use (food, feed, materials, energy), is not always sustainable. Therefore, major efforts are required over the whole value chain to safeguard the sustainable supply of biomass. Key instruments include sustainability frameworks and certification. Although lifecycle GHG emissions from biomass supply and conversion are included, efforts to safeguard sustainability are not part of the modelling framework used in this study and are a key prerequisite in the roadmap towards a bio-based economy; see for example, the Committee on Biomass Sustainability Issues (Commissie Corbey, 2015) ${ }^{30}$.

\subsection{Macroeconomic issues}

The strength of the top-down model is that it connects the bioeconomy sectors with the rest of the economy. There is competition with other sectors to fulfil consumer demand and on the production factor markets (land, labour, capital). It covers the full value chain from biomass to consumers and takes intermediate deliveries into account. There is thus a closed loop between income and expenditures. As MAGNET is a global model it also connects the Netherlands via bilateral trade flows to EU countries and the rest of the world. The extensions built within the MEV II study are innovative as there exists no global CGE with such detail in the new bioeconomy sectors and especially the chemical sector. Although these new sectors are a strength within its own model family it is also its weakness, as detailed technological developments are not taken into account and the level aggregation is still high. Another issue is that policies are often implemented with their subsidy equivalent and not explicitly. A main challenge is that these models are normally calibrated and use econometric estimates of elasticities based on historical data, which is not possible as the new bioeconomy developments have just started. In this study, we circumvented this by using cost structures and learning rates from the bottom-up approach. Elasticities were taken from existing products that are close substitutes.

To examine the complete economic picture, both the revenues from and costs of employing biomass products in different uses should be taken into account (Meijl et al., 2012). The potential revenues derived from adding millions of tonnes of biomass to the production system are relatively easy to calculate; however, the message on the cost side of the equation is more subtle. When economists refer to costs, they mean opportunity costs; in other words, the costs of the second best use of a resource. For instance, the production of biomass products requires the use of inputs such as capital and labour. If those resources are considered idle - in other words, they are not being used productively elsewhere in an economy - their opportunity costs are near zero. However, to the degree that they are being used elsewhere, using them to convert biomass products into fossil fuel substitutes requires that capital, labour and other inputs are pulled away from wherever they are currently used, implying that less of those other goods can be produced. These opportunity costs are often ignored. In this study, we assumed that the production of bioethanol, bio-based chemicals and bio-electricity substitutes for the use of fossil oil for gasoline and chemicals production, while for electricity and

\footnotetext{
${ }^{28}$ Bauen, A. et al., 2013. A harmonised auto-fuel biofuel roadmap for the EU to 2030, London, UK.

29 Ecofys, 2014

30 Commissie Corbey, 2015. Naar een duurzame bio-economie - Visie van de Commissie Duurzaamheidsvraagstukken Biomassa.
} 
pellets the substitute is the production of electricity from coal, natural gas or other renewable sources of energy (e.g. sun and wind). The most important determinant of the macroeconomic benefits of the production of bioethanol, bio-based chemicals and bio-electricity is the difference between the costs of the bio-based products and the price of the fossil resource-based substitute. If the bio-based alternative is cheaper than its fossil substitute, a positive impact on GDP can be expected, and vice versa, if the bio-based alternative is more expensive than its fossil substitute, a negative impact on GDP can be expected.

In short, an important cost of producing bio-based products is a reduction in the production of other goods in the Netherlands as their inputs will be used to produce bio-based products, and/or the input costs increase as demand for inputs increases. Equilibrium models are designed precisely to model trade-offs such as the opportunity costs. By modelling an entire economy, the net benefits of a transition from a fossil resources-based economy to a bio-based economy can be determined. The GDP impact therefore depends very much on the rate of technological development and the biomass prices that influence the bio-based product and the relative price of the fossil resources-based substitute.

In the current situation, hardly any bio-based technologies are cost-competitive and can survive without policies. The bottom-up studies show that technological change is expected to be limited in energy-related biomass technologies and therefore the impact on GDP is negative. The bottom-up studies conclude that technological change is expected to be high for second-generation biofuels and some biochemicals (PLA, PE) and that they will be competitive with their fossil-based substitutes at the assumed oil price of $€ 123$ per barrel in 2030 . These substitution effects will in general have a positive impact on GDP, and that is also what we see in this study (see Section 4.2.1). These effects are very dependent on the fossil prices, and in the low fossil price scenario these products will not be cost competitive and therefore they will appear to a lesser extent and, when forced in by policies, will have a negative impact on GDP (see Section 5.2.1). However, the higher the technological change with these low fossil prices, the lower the negative GDP effect.

In this study, the GDP effects are quite small. In general the GDP impact is 'benefit over its substitute' times the cost share in the economy. First of all, we took the opportunity costs into account, and this makes effects smaller. Secondly, the new sectors are very small and this makes it hard to get a big impact on the overall economy even if technologies are very cost-competitive. A third reason is related to the labour market. In this study, we effectively assumed that the participation rate of the workforce remains unchanged, which at the same time is theoretically consistent with a medium to longer term assumption of a fixed 'natural rate of unemployment'. This assumption implies that there are no shortterm unemployed people who will enter the labour market in this study. Reducing unemployment would have led to higher GDP effects as opportunity costs are zero.

It is important to realize that behind this small GDP growth figure, a relatively large transition from fossil resources-based technologies to biomass-based resources takes place. This implies the largescale substitution of fossil fuels by bio-based alternatives in the petrol/biomass refinery, electricity and chemical industries, leading to all kinds of 'bottlenecks' as capital has to be attracted and built up, people have to be attracted and educated, infrastructure has to be built, export markets have to be developed, and technologies have to be invented and diffused within the sectors. 


\section{$7 \quad$ Conclusions}

The MEV II project conducted a quantitative assessment of the bio-based economy with four main scenarios and a set of sensitivity scenarios to 2030 for the Netherlands. This project looked at effects both at the system level and at the macroeconomic level using a combined approach of a bottom-up model (MARKAL-NL-UU) and a top-down macroeconomic model (MAGNET). Effects at the system level include renewable energy deployment, fossil fuel reduction, GHG mitigation and system costs. Effects at the macroeconomic level include GDP, added value and employment. The four scenarios (RegLowTech, RegHighTech, GlobLowTech, GlobHighTech) were developed over two axes of uncertainty: the rate of technological development and the availability of biomass from outside the EU. The LowTech and HighTech scenarios present a slow rate versus a high rate of technological development. The Reg(ional) and Glob(al) scenarios analysed a shift towards a restricted supply of biomass from only domestic sources in the EU versus a scenario with increasing open trade and a global supply of solid biomass and liquid biofuels. A counterfactual (NoBioBased) scenario was designed in which the production remains at its current level to be able to assess the macroeconomic impact of bio-based technologies. Additional sensitivity cases and scenarios assessed other key uncertainties including low and high fossil fuel prices, $\mathrm{CO}_{2}$ policies (higher levels of $\mathrm{CO}_{2} \operatorname{tax}, \mathrm{CO}_{2}$ emission cap) and sector-specific support (biogas, aviation).

\subsection{Conclusions on impacts at the system level}

\subsubsection{Outcomes of the main scenarios}

Under the assumed scenario conditions (fossil fuel prices, $\mathrm{CO}_{2}$ price, etc.), the binding policy targets of renewable energy is projected to remain the primary driver for the deployment of renewable energy in the Netherlands. However, in case of the open trade scenario combined with high rates of technology development (GlobHighTech), some bioenergy and bio-based material technologies become cheaper than their fossil counterparts, resulting in the deployment of renewable energy beyond policy targets (by $1 \% \mathrm{pp}$ ).

In the short term (i.e. to 2020), first-generation biofuels are only deployed due to the sector-specific target of $10 \%$ in road transport. However, the high technology development scenarios indicate that road transport blending targets are exceeded in 2030 as a result of developments in advanced biofuels.

HighTech scenario conditions also stimulate the production of bio-based chemicals and increase the contribution of biomass to final energy and non-energy uses in the Netherlands. Compared with the low technological development (LowTech) scenarios, a clear trade-off across bio-based applications is seen: low technology development scenarios lead to more heat output from biomass and less biofuel and bio-based chemicals production compared to high technology development scenarios.

\section{Contribution of the energy sectors}

\section{Electricity}

- The bottom-up model MARKAL-NL-UU projects a high contribution of wind (largely stimulated by the Dutch Energy Agreement) and a gradual shift from coal- to natural gas-based electricity by 2030 . There will be limited biomass-based electricity output, which comes mainly from the incineration of the organic fraction of municipal solid waste and biorefineries (especially in high technology development scenarios). Beyond 2015, and under reference scenario assumptions, biomass co-firing in coal plants was not found to be a cost-attractive conversion pathway.

- According to the top-down model MAGNET, the total production of electricity in the Netherlands in 2030 is nearly constant in all four scenarios. The share of fossil-based electricity in total electricity 
production decreases from $75 \%$ in the NoBioBased scenario in 2030 to about $65 \%$ in all four scenarios. The production of electricity from wind \& solar is determined by the Dutch Energy Agreement and is stable across all four scenarios. The share of bioelectricity is about $9 \%$ in all scenarios. In the global scenarios, electricity production from biomass is slightly higher than in regional scenarios, as cheaper pellets are allowed to be imported from all over the world.

\section{Heat}

- Industrial heat is one of the most cost-efficient options to meet EU RED targets (most cost-optimal solution against other fossil and renewable alternatives) at a system level, besides heat output from biomass (fuelwood in wood burning stoves, co-generated heat from municipal solid waste incinerators). Natural gas remains a key fuel for heat services.

\section{Road}

- According to the bottom-up model, first-generation biofuels remain important in low technology development scenarios, whereas FT fuels and second-generation ethanol remain key in the high technology development scenarios. Till 2020, production is driven by policies across all scenario variants; post-2020 technology development stimulates the production of second-generation biofuels (domestically produced FT fuels, and ethanol - either domestically produced or imported, depending on trade openness).

- In the top-down model, the use of biofuels is determined by the mandatory biofuel blending targets in the LowTech scenarios and mostly first-generation fuels are used. In the GlobLowTech scenario, relatively cheap ethanol from America substitutes the use of more expensive biofuels produced in the Netherlands or imported from the rest of the EU. In the HighTech scenarios, the production of second-generation biofuels in the Netherlands becomes competitive. The share of biofuels in the transport fuel mix increases to $12 \%$ in the regional scenario and, due to cheaper feedstock prices, to almost $14 \%$ in the global scenario.

\section{Aviation}

- Without a blending target, bio-based fuels are not supplied to the aviation sector in low technology development scenarios. The cost-effectiveness of FT fuels in high technology development scenarios enables the supply of biojet fuels, but only after 2020. Note that several technologies that supply biojet fuels are assumed in the portfolio (such as hydrotreatment of used cooking oils) that also supply biofuels to road transport, which further diversifies the supply of biofuels to the transport sector.

\section{Contribution of bio-based chemicals/novel materials}

\section{Chemicals}

- According to the bottom-up model, oil naphtha remains the primary feedstock to produce chemicals. Under assumed reference scenario conditions (fossil fuel/sugar prices, demand for chemicals), the production of fermentation chemicals (e.g. polylactic and succinic acid) and bulk chemicals (ethylene from ethanol) is significant. Technology scenarios indicate close competition between conversion technologies. Note that there are no policy targets or preconditions for chemicals, as opposed to energy sectors.

- The key to the deployment of both biofuels and bio-based chemicals is technological advances in lignocellulose conversion to ethanol and sugar in combination with low feedstock costs.

- According to the top-down model, the developments of biochemicals is very dependent on the level of technical change. Key products are polyethylene (PE) from second-generation ethanol, PLA from lignocellulosic sugar and PLA from conventional sugar.

\section{Biomass demand}

- Under the reference scenarios, biomass consumption levels are 225-345 PJ $\mathrm{J}_{\text {prim. }}$. More than $80 \%$ of total biomass is used for heat and fuels (in low technology development) and chemicals (in high technology development).

- Domestic solid biomass resources are cost efficient and are almost fully utilized across all trade and technology scenario variants. Wet biomass (mainly manure used for co-digestion), remains a large 
unutilized potential. Noticeable is the switch from EU to global resources, which offers additional low-cost biomass supply across the trade scenarios.

- Sugar and ethanol biorefineries consume approximately 0-0.7mt w.p.e. $\left(0-12 \mathrm{PJ}_{\text {prim }}\right)$ of solid biomass in 2020, and 0.4-4mt $\mathrm{m}_{\text {w.p.e. }}\left(7-70 \mathrm{PJ}_{\text {prim }}\right)$ in 2030. These outcomes are, however, very sensitive to scenario assumptions (e.g. the $\pm 50 \%$ variation of crude oil price from the reference $\$ 123 /$ barrel in 2030).

\section{Greenhouse gas emissions}

\section{- Bottom-up model}

Under the assumed moderate tax on $\mathrm{CO}_{2}$ emissions (2020: $€ 15.5 / \mathrm{t}, 2030: € 21.6 / \mathrm{t}$ ), national $\mathrm{CO}_{2}$ emissions are expected to decline by 2030 to 2010 levels, but the EU emission reduction target is not achieved in any of the reference scenarios. Reduction is mainly achieved by the electricity and industry sectors, among others by wind energy and use of biomass for heat. The utilization of regional and global biomass decreases emission reduction by $1-3 \%$ (through indirect $\mathrm{CO}_{2}$ emissions, which are not accounted for in domestic emissions).

- Top-down model Introduction of climate change and renewable energy policies and technological change reduce the emissions in the Netherlands by $4-6 \%$ compared to 2015 . The introduction of the biofuel mandate and bioelectricity use contributes $4 \%$; high technological change enables an additional reduction of $1 \%$ in the regional and $2 \%$ in the global scenario.

\subsubsection{Outcomes of sensitivity analysis and additional scenarios}

\section{Fossil fuel prices}

Fossil fuel price variation is the single most influential input parameter with respect to the deployment potential of biomass and other renewable energy technologies, biomass consumption, energy demand reduction (e.g. transport), the emergence of bio-based chemicals and GHG emissions.

- When high fossil fuel prices are assumed, the sustainable biomass supply potential will be almost fully utilized (356-770 PJ compared to 225-345 PJ in reference scenarios). Furthermore, in the HighTech scenarios, a strong GHG emission reduction is achieved, as are a decrease in demand for transport fuels and versatility in the deployment of other biomass conversion technologies, which are not cost-competitive in reference scenarios. In addition, a significant increase in the deployment of wind electricity (beyond the support levels of the Dutch Energy Agreement) is noticed. The chemical sector is greatly affected as the output of bio-based chemicals increases by a factor of 2.5, supplying as much as $40 \% \%_{w t}$ of the demand (excluding ammonia and fertilizers).

- When low fossil fuel prices are assumed, only the policy requirements are met regarding renewable energy share and biofuel blending targets (205-230 PJ compared to 225-345 PJ in reference scenarios). No GHG emission reduction is realized in 2030 compared to 1990 . Biomass consumption levels are similar across all scenarios and the bio-based chemical output drops to $1-3 \%$ of total demand.

\section{$\mathrm{CO}_{2}$ tax and $\mathrm{CO}_{2}$ cap}

$\mathrm{CO}_{2}$ scenarios (high $\mathrm{CO}_{2}$ tax and $\mathrm{CO}_{2} \mathrm{cap}$ ) were found also found to influence several indicators.

- A high $\mathrm{CO}_{2}$ tax leads to an increase in biomass consumption levels (by a factor of 2 compared to reference scenarios) and in combination with CCS deployment to a significant reduction of emissions in the electricity and transport sectors (in the latter case, also through a decrease in demand). A high $\mathrm{CO}_{2}$ tax drives renewable energy consumption beyond policy targets. In the case of open trade and high technology development (GlobHighTech) the 40\% emission reduction target in 2030 compared to 1990 is nearly met. It should be noted though that such tax levels are not sufficient to achieve emission reduction by $40 \%$ compared to 1990 levels in the other scenarios.

- A $\mathrm{CO}_{2} \mathrm{Cap}$, to ensure that emissions do not exceed $87 \mathrm{mt}$ of $\mathrm{CO}_{2}$, significant deployment of CCS. Combining cost-optimization with a common emission target across scenarios, shows that access to low-cost biomass through global trade (under low technology development) or advanced technology deployment (under regional trade scenarios) lead to similar additional costs. 


\section{Sector-specific support: co-digestion of manure}

- In the reference scenarios the use of wet biomass (primarily manure) remains limited. Assuming that manure treatment is required due to environmental policy, biomass consumption levels increase across all scenarios by almost a factor of 2 compared to the reference scenarios. This is due to the large quantities of co-digestate required. The most cost-effective solution is to upgrade biogas to green gas and inject it into the grid for heat applications. A trade-off is that heat from green gas replaces heat from biomass boilers to meet the EU RED renewable energy share target. An implication of this is the short-term increase in emissions by 2020 due to the transport and production of co-digestate, which is mitigated towards 2030. Mandatory manure treatment and subsequent upgrade to green gas creates additional system costs of approximately $€ 400-500 \mathrm{~m} /$ year.

\section{Sector-specific support: aviation biofuels}

- A mandatory blending target for biojet fuel production leads to hydtrotreated biodiesel supply to road transport in 2020-2030 and hydtrotreated biojet supply in aviation in 2020. To 2030, biojet supply differs in technology scenarios: hydtrotreated biojet supplies the aviation sector in LowTech scenarios. FT fuels supply the aviation sector with biojet in HighTech scenarios, and also allow solid biomass to be redirected from heat to FT fuels (also suitable as aviation fuels), thus meeting the EU RED renewable energy share target.

\section{Sector-specific sensitivity: decrease demand for chemicals}

- Assuming that the demand for chemicals decreases (an insight provided by the top-down analysis), there will be a significant decrease in the bio-based chemical output by as much as $60 \%$. In most scenarios, PLA and ethylene from ethanol remain important chemicals leading again to the conclusion that sugar prices and advancements in second-generation technologies are key.

\section{Sector-specific sensitivity: variation in domestic biomass supply}

- Additional biomass supply (either from domestic resources, e.g. municipal solid waste and digestion feedstocks) or low-cost EU supply does not seem to influence the outcomes, as sufficient biomass is already available. More elaborate analyses are required to assess the robustness of this conclusion.

\subsection{Conclusions on impacts at the macroeconomic level}

In this study an extended version of the Modular Applied GeNeral Equilibrium Tool (MAGNET) was developed. Various biomass supply and biomass conversion sectors were added and the representation of the conventional energy sectors was refined. Furthermore, MAGNET was extended with $\mathrm{CO}_{2}$ emissions module, energy and climate change policies, including $\mathrm{CO}_{2}$ taxes, GHG reduction targets and blending targets for first- and second-generation biofuels, bioenergy and renewable energy targets.

\section{GDP effects}

- The GDP effects can be positive or negative relative to a NoBioBased scenario. In the GlobHighTech scenario, a high speed of technological change and global open markets result in the highest GDP value. The RegLowTech scenario, which has low technological change and regional EU markets, results in the lowest GDP value in 2030. The GDP difference between the two scenarios is about $€ 1,050 \mathrm{~m}$ or $0.12 \%$ of GDP of the Netherlands.

- A $€ 0.2 b n$ negative GDP effect occurs in the regional LowTech scenario (compared to a NoBioBased scenario). This is the result of renewable energy policies that require the use of bio-based technologies that are not competitive.

- Higher technical change adds $€ 350 m$ to GDP when global biomass trade is assumed (difference between GlobHighTech and GlobLowTech) and about $€ 750 \mathrm{~m}$ if biomass is sourced from within the EU.

- The global dimension adds almost $€ 700 m$ to GDP in the LowTech situation (difference between GlobLowTech and RegLowTech) and almost $€ 300 \mathrm{~m}$ in the HighTech situation (difference between GlobHighTech and RegHighTech). 
- Relative to the negative GDP effect in the RegLowTech scenario, opening up markets or investing in tech change induces a positive GDP effect; that is, the overall GDP effect becomes positive.

Combining high technical change and open markets leads the highest positive GDP effect.

\section{Added value}

- The bioeconomy has a positive impact on the value added of the Dutch economy. Relative to a NoBioBased scenario, the bioeconomy sectors contribute $€ 580 \mathrm{~m}$ in the case of a LowTech scenario and almost $€ 800 \mathrm{~m}$ in the case of a HighTech scenario.

- Within the bioeconomy, agriculture is a key sector in terms of value added. The value added of agriculture decreases slightly (by $€ 160 \mathrm{~m}$ ) between 2015 and 2030 in the NoBioBased scenarios. In all four MEV II scenarios the value added in the Netherlands increases due to the emergence of the broader bioeconomy. The increase in value added relative to the NoBioBased is higher in the HighTech than the LowTech scenarios by respectively about $€ 200 \mathrm{~m}$ and $€ 120 \mathrm{~m}$. The opening up of trade has a very minor negative impact $(€ 40 \mathrm{~m})$ on Dutch agricultural value added.

- The value added in the biochemical sectors increases by $€ 130 \mathrm{~m}$ in the LowTech scenarios and by $€ 250 \mathrm{~m}$ in the HighTech scenarios (compared to a NoBioBased scenario). Biofuels and bioenergy are largely driven by policies and value added is fairly constant across the scenarios. Relative to the NoBioBased scenario, the value added of bioenergy is about $€ 280 \mathrm{~m}$.

\section{Employment}

- The decline in employment in agriculture between 2015 and 2030 also leads to a decline in employment in the bioenergy \& biochemical sectors. The bioeconomy only partially mitigates this effect, partly because we assume full employment in 2030 and thus the bioeconomy competes with other sectors for labour.

- The highest employment impacts come from the production of bio-based chemicals in the case of the HighTech scenarios and to a smaller extent in the GlobLowTech scenario.

\section{Biochemicals}

- The value of bio-based chemicals production is about $€ 2 b n$ in the high technology scenarios and $€ 700 \mathrm{~m}$ in the low technology scenarios.

- The production value of bio-based polyethylene is $€ 600 \mathrm{~m}$ in the LowTech scenarios and $€ 1$,7bn in the HighTech scenarios. The production of PLA from conventional sugar and lignocellulosic sugar increases to, respectively, $€ 60 \mathrm{~m}$ and $€ 200 \mathrm{~m}$ in the low and HighTech scenarios.

\section{Biomass trade}

- The total trade balance in the Netherlands deteriorates in bioeconomy scenarios. The positive impact of RED policies and technological change in chemical technologies on the energy and chemical trade balance is more than offset by increased biomass imports and especially an deterioration of the other industries and services trade balance. The latter deteriorates as resources are pulled away from these sectors to less competitive sectors. As technological change gets higher, the negative impact becomes smaller. Biomass (pellets, residues) and biofuels are imported to fulfil the RED mandates and primary agricultural exports decline. In the HighTech scenarios, the deterioration in the trade balance is less, as chemical and second-generation biofuel exports increase. In the LowTech scenario, fossil energy is substituted by first-generation biofuels, but as part of these are produced domestically the energy trade balance improves. In the HighTech scenario, substitution of fossil by bio-based substitutes occurs and also the second-generation and chemical markets grow, which implies less savings on fossil energy imports. However, this results in bio-based exports that substitute for fossil energy in other countries.

\subsubsection{Sensitivity analyses}

Lower fossil energy prices:

- The competitiveness of bio-based technologies is primarily determined by fossil energy prices.

- Lower fossil energy prices reduce the bioeconomy to the requirements of the RED policies. Biochemicals will almost disappear.

- High technological change results in substitution of first-generation technologies with secondgeneration biofuel production, but no additional production compared to the blend mandates. 
- GHG emissions increase substantially and $\mathrm{CO}_{2}$ taxes are insufficient to keep emissions at current levels.

- GDP effects of low fossil energy prices are positive. Open markets and high technological change in bio-based technologies further increase the positive impact compared to regional markets and low technological change.

$24 \% \mathrm{CO}_{2}$ reduction in the Netherlands ( $16 \%$ is achieved by CCS, based on MARKAL-NL-UU):

- In this sensitivity scenario, a 40\% GHG reduction has to be achieved in the Netherlands. Based on MARKAL-NL-UU input, a $16 \%$ reduction is achieved by CCS. Therefore GHG emissions are reduced by $26 \%$ in MAGNET, which has no options for CCS. So $40 \%$ of the $40 \%$ decrease in emissions is realized through CCS, of which the costs are not considered in MAGNET.

- Wind energy that substitutes gas and coal makes the largest contribution to achieve a $24 \%$ reduction in GHG emissions in the Netherlands. Achieving the $24 \%$ target costs between $0.55 \%$ and $1 \%$ of GDP. These results are in the same order of magnitude as values found in the literature. For example, Hof et al. (2012) reports mitigation costs of between $0.25 \%$ and $0.4 \%$ of GDP by 2030 to achieve a $40 \%$ reduction in EU domestic emissions.

- The costs are highest in the NoBioBased scenario and equal $1 \%$ of GDP. The costs in terms of GDP decline if biomass markets are global and especially if technological change is higher in the biobased technologies.

- Global markets together with high technological change reduce the reduction in GDP by $0.5 \%$ relative to the NoBioBased scenario. However, these results have to be interpreted with care, as this scenario stretches the model to its limit as potentially not all substitutional effects are taken into account.

- Further, emissions trading and other flexibility mechanisms would allow countries to realize emission reductions in other countries at lower costs. Biomass becomes an attractive and cost-efficient option when the $40 \%$ reduction target is implemented in the Netherlands.

Increased agricultural productivity:

- In the main scenarios, we assume only additional technological change in the bio-based fuel and chemical technologies and no additional improvements in the agricultural sector are considered, which is the main sector in the bioeconomy complex. In this sensitivity scenario, yields in the Netherlands increase by $10 \%$ in the crop sectors and forestry.

- Higher yields in primary sectors such as agriculture and forestry lead to significant positive GDP effects, as especially the export-oriented agri-food industries can increase their market share without having to decrease their price levels. The GDP impact of a yield increase $(10 \%)$ is higher $(0.3 \%$ of GDP) versus $0.12 \%$ of GDP in the GlobHighTech scenario.

- The indirect benefits of the new bioeconomy sectors are limited, as these sectors source only a small share from domestic agricultural primary products and feedstock prices on a global level do not decline a lot.

- Value added increases sharply in the global high-tech scenario. However, most of the increase can be attributed to the agricultural sectors. So the direct impact the productivity change has on the agricultural sectors is much more important for value added than the indirect effects on other bioeconomy sectors.

Higher sugar beet yields and lower sugar prices:

- Higher yields in the sugar beet sector and lower sugar prices increase the value added by $€ 34 \mathrm{~m}$ in the bioeconomy and especially the sugar sector.

- The lower sugar price also increases the value added in bio-based chemicals $(€ 5-8 \mathrm{~m})$ and, to a lesser extent, biofuels.

- In the regional and global high technology scenarios, the sugar shock induces more PLA production from lignocellulosic sugar.

\subsection{Future research}

The MEV II study was designed on the basis of a midterm temporal scope (2030) and a large-scale deployment potential for biomass conversion technologies across different sectors. To a large extent, 
this defined the role that biomass might have as reflected by the study's outcomes. In the discussion, the impact of this assumption on the core assumptions of this study, such as the selection of technologies, substitution possibilities and policy drivers. The time frame therefore cannot be extended simply by extrapolating from the outcomes of MEV II. We recommend further research to extend the temporal scope to e.g. 2050, whereby technological learning and economies of scale may reveal a larger role for biomass due to the improved cost competitiveness of technologies, improvements in biomass value chains, etc. Alternative renewable energy sources (wind, sun) and substitutes for materials should also be taken into account. By extending the temporal scope, it is also recommended to diversify and extend the technology portfolio covered by the study. This is particularly relevant for biomass conversion technologies to chemicals. Innovative production routes may have a significant impact (e.g. lignin valorization to high-value products). Finally, a study that assesses a longer term can focus not only on the replacement of bulk fossil fuels but also on highvalue, low-volume products. Although such routes may not play a significant role in bridging emission reduction gaps or in substituting large volumes of fossil fuel, they can have a large impact on the bioeconomy in terms of value added (e.g. specialty chemicals). Such a study would be more forward looking, and more bold assumptions would have to be made and the degree of uncertainty would be larger. However, it might provide insights into which technologies require support now in order to stimulate their deployment in the future. It should include scaling-up, synergies with technologies that might improve their economics due to valorization of side-streams, and returns for the Dutch economy. 


\section{References and websites}

Argus Media (2012). Energy and commodity price benchmarking and market insights. Available online:

\section{www.argusmedia.com/News/Webinars-and-}

Presentations/ / /media/35E3FFB7461840A4B26F38A28CC4C16A.ashx

Asche, F., Gjølberg, O., Völker, T. (2003). Price relationships in the petroleum market: an analysis of crude oil and refined product prices. Energy Economics, 25, 289-301.

Bain, R.L. (2007) World Biofuels Assessment; Worldwide Biomass Potential: Technology Characterizations. National Renewable Energy Laboratory (NREL). Colorado.

Banse, M., H. van Meijl, A. Tabeau and G. Woltjer (2008). "Will EU biofuel policies affect global agricultural markets?", European Review of Agricultural Economics 35 (2): 117-141.

Broeren, M.L.M., Saygin, D., Patel, M.K. (2014). Forecasting global developments in the basic chemical industry for environmental policy analysis. Energy Policy, 64, 273-287.

Brouwer, A.S., van den Broek, M., Seebregts, A., Faaij, A. (2015). Operational flexibility and economics of power plants in future low-carbon power systems. Submitted for publication. Available on request.

CBS (2015). Energy balance sheet. Statistics Netherlands (CBS). Den Haag/Herleen. Available online: www.statline.cbs.nl. Last accessed: 19-06-2015.

Chemweek (2000-2009). Process information. Chemical Week. New York.

Couch, K.A., Glavin, J.P., Wegerer, D.A., Qafisheh, J.A. (2007). FCC propylene production. Universal Oil Products LLC (UOP).

Dammer, L., Carus, M., Raschka, A., Scholz, L. (2013). Market Developments of and Opportunities for biobased products and chemicals. nova-Institut. Hürth.

Daioglou, V., E. Stehfest, B. Wicke, A. Faaij and D.P. van Vuuren (2015). Projections of the availability and cost of residues from agriculture and forestry. GCB Bioenergy: n/a-n/a

EC (2009). On the promotion of the use of energy from renewable sources and ameding subsequently repealing Directives 2001/77/EC and 2003/30/EC. 16-62. Official Journal of the European Union, 23 April 2009. European Commission, Brussels.

EC (2012). Innovating for Sustainable Growth: A Bioeconomy for Europe. $\operatorname{COM(2012)~} 60$ final. Brussels, Belgium, European Commission.

EC (2014). A policy framework for climate and energy in the period from 2020 to 2030. COM(2014) 15 final. Brussels, Belgium, European Commission.

ECN (2015). Energiebalans en $\mathrm{CO}_{2}$-emissie. MONITweb. Available online: www.monitweb.energie.nl Petten.

Eickhout, B., H. van Meijl, A. Tabeau and E. Stehfest (2009). "The impact of environmental and climate constraints on global food supply", in T. Hertel, S. Rose and R. Tol (eds.), Economic Analysis of Land Use in Global Climate Change Policy, Routledge, London and New York, pp. 206-234.

Elbersen, B. (2015). Outlook of spatial biomass value chains in EU28 Deliverable 2.3 of the Biomass Policies.

Eurostat (2014). Labour costs database. European Commission. Available online: http://ec.europa.eu/eurostat/web/labour-market/labour-costs. Last accessed: 21-05-2014.

Hamelinck, C.N., Hooijdonk, G., Faaij, A.P.C. (2005). Ethanol from lignocellulosic biomass: technoeconomic performance in short-, middle- and long-term. Biomass and Bioenergy. 28 (4), 384-410.

Hermann, B.G., Patel, M. (2007). Today's and tomorrow's biobased bulk chemicals from white biotechnology. Applied Biochemistry and Biotechnology, 136, 361-388.

Hertel, T.W. (Ed.) (1997). Global Trade Analysis Modelling and Applications, Cambridge University Press, Cambridge.

Hoefnagels, R., Resch, G., Junginger, M., Faaij, A. (2014b). International and domestic uses of solid biofuels under different renewable energy support scenarios in the European Union. Applied Energy, 131, 139-157. doi: 10.1016/j.apenergy.2014.05.065. 
Hoefnagels, R., Searcy, E., Cafferty, K., Cornelissen, T., Junginger, M., Jacobson, J., Faaij, A. (2014a). Lignocellulosic feedstock supply systems with intermodal and overseas transportation. Biofuels, Bioproducts and Biorefining, 8(6), 794-818. doi:10.1002/bbb.1497.

ICIS (2008). Indicative Chemical Prices A-Z. Available online: www.icis.com/chemicals/channel-infochemicals-a-z. Last accessed: 18-09-2014.

IEA (2009). Energy technology transitions for industry - Strategies for the next industrial revolution. Organisation for Economic Co-operation and Development (OECD)/International Energy Agency (IEA), Paris.

Jonker, J.G., van der Hilst, F., Junginger, H.M., Cavalett, O., Chagas, M.F., Faaij, A.P.C. (2015). Outlook for ethanol production cost in Brazil up to 2030, for different biomass crops and industrial technologies. Applied Energy, 147, 593-610.

Koppejan, J., Elbersen, W., Meeusen, M., Bindraban, P. (2009). Beschikbaarheid van Nederlandse biomassa voor elektriciteit en warmte in 2020. Procede Biomass, rapportage in opdracht van SenterNovem.

Lako, P. (2009). Energy conservation potential of the nitrogen fertiliser industry. Energy Research Center of the Netherlands (ECN). ECN-E-09-011. Petten.

Lamers, P., D. Marchal, J. Heinimö and F. Steierer (2014a). Woody biomass trade for energy. International Bioenergy Trade: History, status \& outlook on securing sustainable bioenergy supply, demand and markets. M. Junginger, C. S. Goh and A. Faaij. New York, USA, Springer Science \& Business Media.

Lamers, P., F. Rosillo-Calle, L. Pelkmans and C. Hamelinck (2014b). Developments in international liquid biofuel trade. International Bioenergy Trade: History, status \& outlook on securing sustainable bioenergy supply, demand and markets. M. Junginger, C. S. Goh and A. Faaij. New York, USA, Springer Science \& Business Media.

Lamers, P., R. Hoefnagels, M. Junginger, C. Hamelinck and A. Faaij (2014). Global solid biomass trade for energy by 2020: an assessment of potential import streams and supply costs to North-West Europe under different sustainability constraints. GCB Bioenergy 7(4): 618-634.

Lensink, S.M., Mozaffarian, M., Beurskens, L.W.M., Kraan, C.M., Slobbe, J.A. (2014). Verkenning van biomassamarkten en hernieuwbare-energiebeleid. Energieonderzoek Centrum Nederland (ECN). ECN-E-14-019. Petten.

Lotze-Campen, H., von Lampe, M., Kyle, P., Fujimori, S., Havlik, P., van Meijl, H., Hasegawa, T., Popp, A., Schmitz, C., Tabeau, A., Valin, H., Willenbockel, D. and Wise, M. (2014). Impacts of increased bioenergy demand on global food markets: an AgMIP economic model intercomparison. Agricultural Economics, 45: 103-116. doi: 10.1111/agec.12092.

http://onlinelibrary.wiley.com/doi/10.1111/agec.12092/pdf

Loulou, R., Goldstein, G., Noble, K. (2004). Documentation for the MARKAL Family of Models. Energy Technology Systems Analysis Program (ETSAP). Paris.

Min EZ (2015). Biomassa 2030, strategische visie over inzet biomassa op weg naar 2030, Den Haag. McKinsey (2012). McKinsey on Chemicals. McKinsey \& Company. Available online: www. mckinsey.com Neelis, M.L., Patel, M.K., Bach, P. (2003). Inventory of processes in the chemical and refinery industries. Utrecht.

Neelis, M.L., Patel, M.K., Gielen, D.J., Blok, K. (2005). Modelling CO2 emissions from non-energy use with the non-energy use emission accounting tables (NEAT) model. Resources, Conservation and Recycling, 45, 226-250.

Neelis, M., Patel, M.K., Bach, P., Blok, K. (2007a). Analysis of energy use and carbon losses in the chemical industry. Applied Energy, 84, 853-862.

Neelis, M., Patel, M.K., Blok, K., Haije, W., Bach, P. (2007b). Approximation of theoretical energysaving potentials for the petrochemical industry using energy balances for 68 key processes. Energy, 32, 1104-1123.

Nelson, G., H. Ahammad, D. Deryng, J. Elliott, S. Fujimori, P. Havlik, E. Heyhoe, P. Kyle, M. von Lampe, H. Lotze-Campen, D. Mason d'Croz, H. van Meijl, D. van der Mensbrugghe, C. Müller, R. Robertson, R.D. Sands, E. Schmid, C. Schmitz, A. Tabeau, H. Valin, D. Willenbockel (2013). Assessing uncertainty along the climate-crop-economy modeling chain, Proceedings of the National Academy of Sciences U.S.A. 111(9): 3274-3279.

http://www.pnas.org/content/early/2013/12/12/1222465110.abstract (9.81 Impact Factor).

Nowicki, P., V. Goba, A. Knierim, H. van Meijl, M. Banse, B. Delbaere, J. Helming, P. Hunke, K. Jansson, T. Jansson, L. Jones-Walters, V. Mikos, C. Sattler, N. Schlaefke, I. Terluin and 
D. Verhoog (2009). Scenar 2020-II - Update of Analysis of Prospects in the Scenar 2020 Study, Contract No. 30-CE-0200286/00-21. European Commission, Directorate-General Agriculture and Rural Development, Brussels. Available from http://ec.europa.eu/agriculture/analysis/external/ scenar2020ii/ report en.pdf.

OECD/FAO (2014). OECD-FAO Agricultural Outlook 2014. Organisation for Economic Co-operation and Development (OECD)/Food and Agriculture Organization of the United Nations (FAO). OECD Publishing. doi: http://dx.doi.org/10.1787/agr outlook-2014-en

OECD/IEA (2015). World Energy Outlook 2014. Organisation for Economic Co-operation and Development (OECD)/International Energy Agency (IEA), Paris.

OGJ (2009). Worldwide Refineries-Capacities. Oil \& Gas Journal. PennWell Petroleum Group. Tulsa OGJ (2012). Global ethylene capacity continues advance in 2011. Oil \& Gas Journal. 78. PennWell Petroleum Group. Tulsa.

RIVM (2015). Pollutant Release and Transfer Register. Rijksinstituut voor Volksgezondheid en Milieu (RIVM). Available online: www.emissieregistratie.nl. Last accessed: 19-06-2015.

Robinson, S., van Meijl, H., Willenbockel, D., Valin, H., Fujimori, S., Masui, T., Sands, R., Wise, M., Calvin, K., Havlik, P., Mason d'Croz, D., Tabeau, A., Kavallari, A., Schmitz, C., Dietrich, J.P. and von Lampe, M. (2014). Comparing supply-side specifications in models of global agriculture and the food system. Agricultural Economics, 45: 21-35. doi: 10.1111/agec.12087

http://onlinelibrary. wiley.com/doi/10.1111/agec.12087/pdf

RVO (2015). Catalogus van Nederlandse Biobrandstofinitiatieven. Rijksdienst voor Ondernemend Nederland. Available online: www.sn-gave.nl. Last accessed: 16-03-2015.

Saygin, D., Wetzels, W., Worrell, E., Patel, M.K. (2013). Linking historic developments and future scenarios of industrial energy use in the Netherlands between 1993 and 2040. Energy Efficiency, 6, 341-368

SER (2013). Summary of Energy Agreement for Sustainable Growth. The Social and Economic Councin of the Netherlands. The Hague.

Shen, L., Haufe, J., Patel, M.K. (2009). Product overview and market projection of emerging biobased plastics (PROBIP), Utrecht University, Utrecht.

Stehfest, E., D. Van Vuuren, T. Kram, L. Bouwman, R. Alkemade, M. Bakkenes, H. Biemans, A. Bouwman, M. Den Elzen, J. Janse, P. Lucas, J. Van Minnen, M. Müller and A. Prins (2014). Integrated Assessment of Global Environmental Change with IMAGE 3.0. Model description and policy applications. The Hague, The Netherlands PBL Netherlands Environmental Assessment Agency.

Smekens, K., (2005). Technology R\&D and $\mathrm{CO}_{2}$ Policy Scenarios, The MARKAL Model Work for SAPIENTIA, ECN-C-05-059. ECN, Petten.

Tsiropoulos, I., Hoefnagels, R., van den Broek, M., Patel, M.K., Faaij, A. (forthcoming), Deployment pathways of bioenergy and biobased chemicals: an integrated systems analysis of electricity, heat, fuels and chemicals for the Netherlands. Available on request.

UN Comtrad database (2015). UN Comtrade database website http://comtrade.un.org/

Van den Broek, M., Faaij, A., Turkenburg, W. (2008). Planning for an electricity sector with carbon capture and storage. Case of the Netherlands. International Journal of Greenhouse Gas Control, 2, 105-129.

Van den Broek, M., Veenendaal, P., Koutstaal, P., Turkenburg, W., Faaij, A. (2011). Impact of international climate policies on $\mathrm{CO} 2$ capture and storage deployment. Energy Policy, 39, 2000-2019.

Van Meijl, H., T. van Rheenen, A. Tabeau, B. Eickhout (2006). "The impact of different policy environments on land use in europe", Agriculture, Ecosystems and Environment 114 (1): 21-38.

Van Leeuwen et al., LEI report Dutch agrocomplex, 2012.

Van Vliet, O., van den Broek, M., Turkenburg, W., Faaij, A. (2011). Combining hybrid cars and synthetic fuels with electricity generation and carbon capture and storage. Energy Policy, 39, 248-268.

Verdonk, M. and W. Wetzels (2012). Referentieraming energie en emissies: actualisatie 2012. Energie en emissies in de jaren 2012, 2020 en 2030. The Hague, The Netherlands, Netherlands Environmental Assessment Agency; Energy Centre of the Netherlands: 72.

Von Lampe, M., Willenbockel, D., Ahammad, H., Blanc, E., Cai, Y., Calvin, K., Fujimori, S., Hasegawa, T., Havlik, P., Heyhoe, E., Kyle, P., Lotze-Campen, H., Mason d'Croz, D., Nelson, G.C., Sands, R.D., Schmitz, C., Tabeau, A., Valin, H., van der Mensbrugghe, D. and van Meijl, H. 
(2014). Why do global long-term scenarios for agriculture differ? An overview of the AgMIP Global Economic Model Intercomparison. Agricultural Economics, 45: 3-20. doi: 10.1111/agec.12086

http://onlinelibrary.wiley.com/doi/10.1111/agec.12086/pdf

VNPI (2015). Capaciteit- en capaciteitsbenutting Nederlandse raffinaderijen. Vereniging Nederlandse Petroleum Industrie (VNPI). The Hague.

Winkel, J., (2015). personal communication via email (08-12-2015).

Woltjer, G.B. (2011). "Meat consumption, production and land use: model implementation and scenarios", WOT-working document 269, Wageningen University, Wageningen.

Woltjer, G.B., Kuiper, M., Kavallari, A., van Meijl, H., Powell, J. Rutten, M., Shutes, L. and Tabeau, A. (2013). The Magnet Model - Module description. LEI, The Hague. 


\section{Appendix 1 MEV I scenarios in the 2009 study}

The MEV I study included four main scenarios that vary over two key uncertainty variables as shown in the graph below: (1) international cooperation \& trade and (2) technological development rate. In the scenarios with more global orientation (the GlobLowTech and GlobHighTech scenarios), it is assumed that biomass resources are available for the Netherlands at global level, whereas for the scenarios with more regional orientation, the biomass market is limited to European resources of biomass ('RegLowTech' and 'RegHighTech' scenarios). Conversion technologies in the scenarios with conservative technological development (LowTech) are assumed only to have technologies available that are already used commercially today. For the scenarios with enhanced technological development (HighTech), advanced conversion technologies, such as second-generation biofuels, are assumed to become available by 2015 . The GlobHighTechAC scenario is similar to the GlobHighTech scenario, but includes a mix of the three types of bio-based chemicals that are assessed individually in the other scenarios (bio-based hydrogen, bio-based ethylene and caprolactam) to substitute $25 \%$ of fossil raw materials in the chemical sectors in 2030.

\section{International trade}

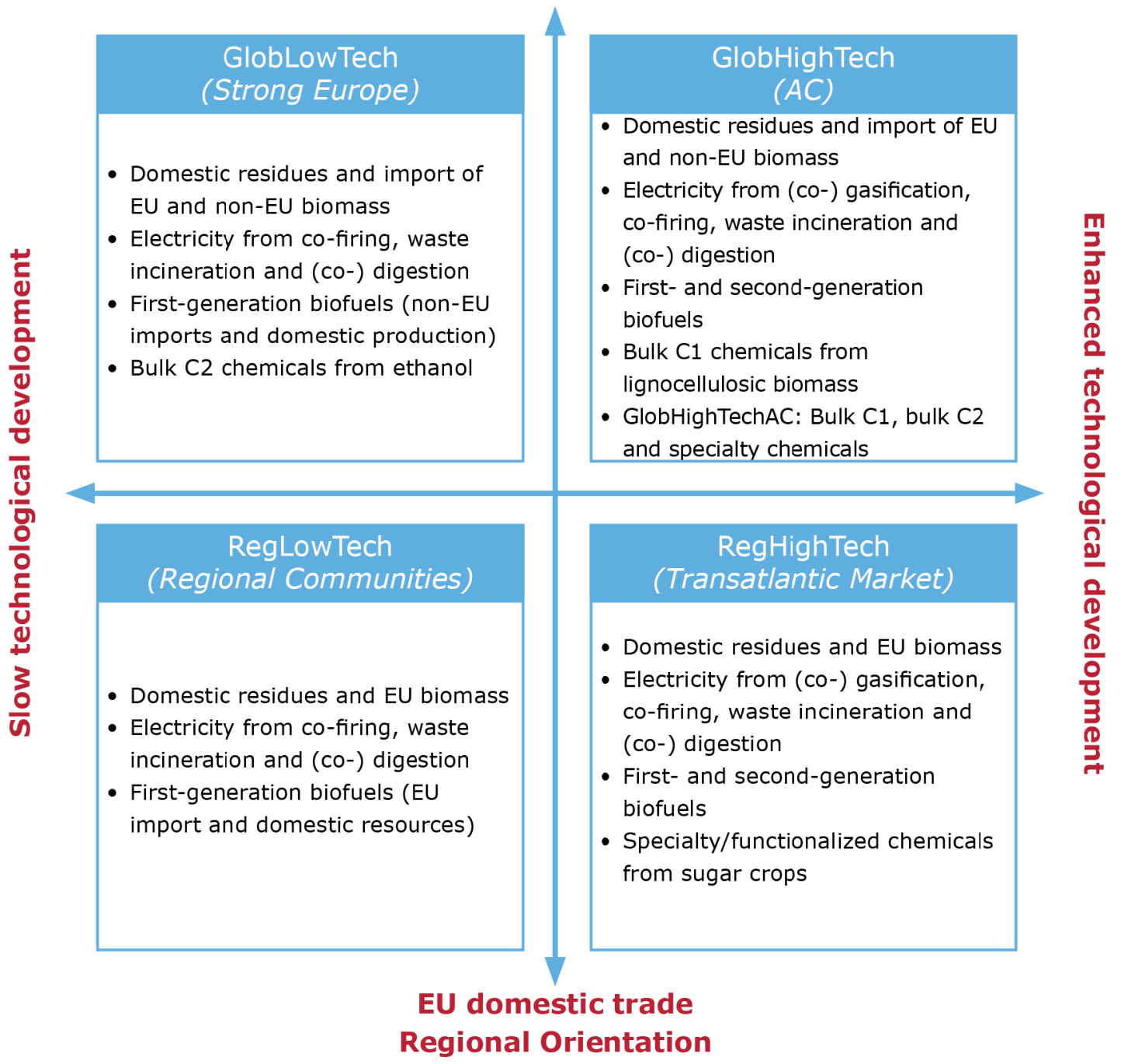

Figure 89 MEV I scenarios and key biomass supply and conversion options per scenario (Hoefnagels et al., 2013) 


\section{Appendix 2 Input data MARKAL-NL-UU}

\section{Biomass supply}

Figure 90 presents the categorization of feedstocks in MARKAL-NL-UU and the biomass conversion pathways they are associated with in the bottom-up framework.

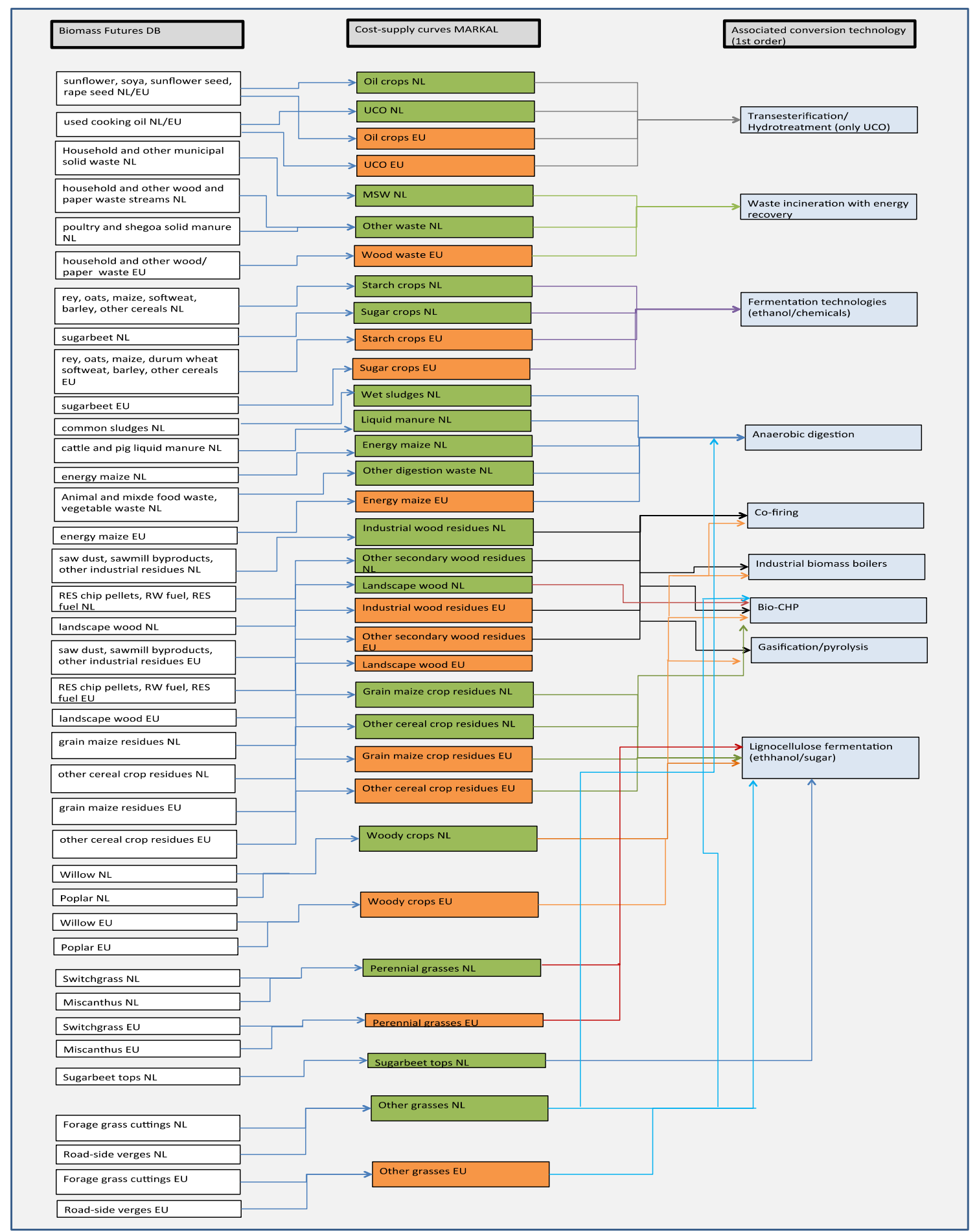

Figure 90 Biomass feedstock categories used in MARKAL-NL-UU. First column (left) refers to feedstocks in S2Biom/biomasspolicies.eu, second column (middle) refers to the aggregation of these categories to feedstocks used in MARKAL-NL-UU (cost-supply data are weighted average for 4 EU regions), third column (left) refers to categories of conversion technologies where these feedstocks can be supplied 
Table 25 presents the input data for a) biomass availability in the Netherlands and the four EU regions as extracted by the Biomass Policies/S2BIOM project b) cost of supply of biomass from the four EU regions to the Netherlands (i.e. roadside costs including transport costs to the Netherlands), and separately c) transport costs of biomass to the Netherlands per biomass type.

\section{Table 25}

Biomass availability and cost of supply for the Netherlands and four EU-28 regions (excluding Netherlands) for energy and non-energy applications used in MARKAL-NL-UU

\begin{tabular}{|c|c|c|c|c|c|c|c|c|c|}
\hline & \multicolumn{3}{|c|}{ Biomass availability (PJ) } & \multicolumn{3}{|c|}{$\begin{array}{l}\text { Cost of supply } \\
(\mathcal{C} / G J)\end{array}$} & \multicolumn{3}{|c|}{$\begin{array}{l}\text { of which transport costs } \\
\qquad(\mathrm{C} / \mathrm{GJ})\end{array}$} \\
\hline & 2010 & 2020 & 2030 & 2010 & 2020 & 2030 & 2010 & 2020 & 2030 \\
\hline Oil crops NL & 0.2 & 0.2 & 0.5 & 0.3 & 18.3 & 27.0 & & & \\
\hline Oil crops East EU & 3.2 & 3.2 & 5.7 & 5.2 & 17.3 & 24.8 & 6.0 & 6.5 & 7.1 \\
\hline Oil crops North EU & 1.3 & 1.3 & 2.0 & 1.7 & 17.5 & 26.0 & 5.0 & 5.3 & 5.0 \\
\hline Oil crops South EU & 0.8 & 0.8 & 1.5 & 1.3 & 20.5 & 26.9 & 7.5 & 7.5 & 7.4 \\
\hline Oil crops West EU & 7.8 & 7.8 & 11.6 & 11.4 & 20.9 & 20.9 & 3.9 & 4.2 & 4.2 \\
\hline Used Cooking Oil NL & 2.1 & 2.5 & 2.8 & 8.6 & 8.6 & 8.6 & & & \\
\hline Used Cooking Oil East EU & 0.4 & 0.4 & 0.4 & 13.7 & 13.7 & 13.6 & 5.8 & 5.8 & 5.7 \\
\hline Used Cooking Oil North EU & 0.6 & 0.6 & 0.7 & 12.5 & 12.5 & 12.4 & 4.9 & 4.9 & 4.9 \\
\hline Used Cooking Oil South EU & 1.7 & 1.8 & 1.9 & 14.4 & 14.4 & 14.4 & 6.7 & 6.7 & 6.7 \\
\hline Used Cooking Oil West EU & 1.8 & 1.8 & 1.9 & 11.1 & 11.1 & 11.1 & 3.3 & 3.3 & 3.3 \\
\hline Sugar crops NL & 0.3 & 2.4 & 3.6 & 19.4 & 19.6 & 21.1 & & & \\
\hline Sugar crops East EU & 0.1 & 0.5 & 0.7 & 22.9 & 15.5 & 17.5 & 4.2 & 5.9 & 4.7 \\
\hline Sugar crops North EU & 0.1 & 0.4 & 1.4 & 22.9 & 15.5 & 17.5 & 3.7 & 5.2 & 4.5 \\
\hline Sugar crops South EU & & 1.2 & 2.2 & 22.9 & 15.5 & 17.5 & 0.0 & 7.1 & 7.2 \\
\hline Sugar crops West EU & 2.6 & 2.5 & 2.6 & 22.9 & 15.5 & 17.5 & 3.1 & 3.0 & 3.0 \\
\hline Starch crops NL & 0.6 & 0.7 & 0.8 & 9.7 & 11.0 & 15.6 & & & \\
\hline Starch crops East EU & 1.6 & 2.8 & 4.2 & 22.9 & 15.5 & 17.5 & 5.9 & 6.9 & 6.8 \\
\hline Starch crops North EU & 1.2 & 1.2 & 2.8 & 22.9 & 15.5 & 17.5 & 4.7 & 4.7 & 4.9 \\
\hline Starch crops South EU & 2.7 & 3.9 & 4.7 & 22.9 & 15.5 & 17.5 & 6.4 & 6.7 & 6.6 \\
\hline Starch crops West EU & 2.6 & 1.7 & 1.8 & 22.9 & 15.5 & 17.5 & 4.5 & 4.7 & 4.7 \\
\hline Municipal solid waste NL & 10.1 & 8.1 & 8.6 & 0.7 & 0.7 & 0.7 & & & \\
\hline Solid manure NL & 17.2 & 17.2 & 17.7 & 3.8 & 3.8 & 3.8 & & & \\
\hline Liquid manure NL & 36.5 & 35.6 & 35.1 & 0.8 & 0.8 & 0.8 & & & \\
\hline Common sludges NL & 6.6 & 7.7 & 8.6 & 0.7 & 0.7 & 0.7 & & & \\
\hline Other digestible waste NL & 35.1 & 9.2 & 10.3 & 2.4 & 2.5 & 2.5 & & & \\
\hline Energy maize $\mathrm{NL}$ & 0.8 & 0.4 & 0.2 & 2.8 & 2.8 & 2.8 & & & \\
\hline Energy maize East EU & 0.5 & 0.1 & 0.0 & 6.4 & 6.4 & 6.4 & 5.1 & 5.1 & 5.1 \\
\hline Energy maize North EU & 0.2 & 0.1 & 0.1 & 6.0 & 6.0 & 6.0 & 4.7 & 4.2 & 4.2 \\
\hline Energy maize South EU & 0.0 & 0.0 & 0.0 & 8.8 & 8.8 & 8.8 & 7.0 & 6.3 & 6.3 \\
\hline Energy maize West EU & 6.5 & 4.4 & 4.6 & 5.6 & 5.6 & 5.6 & 3.6 & 4.0 & 4.0 \\
\hline $\begin{array}{l}\text { Secondary forestry residues } \\
\text { NL }\end{array}$ & 3.2 & 3.3 & 3.3 & 3.3 & 3.3 & 3.3 & & & \\
\hline $\begin{array}{l}\text { Secondary forestry residues } \\
\text { East EU }\end{array}$ & 8.0 & 9.6 & 12.3 & 8.9 & 8.9 & 9.0 & 6.0 & 6.1 & 6.1 \\
\hline $\begin{array}{l}\text { Secondary forestry residues } \\
\text { North EU }\end{array}$ & 22.1 & 24.4 & 27.5 & 9.7 & 9.7 & 9.7 & 6.7 & 6.7 & 6.7 \\
\hline $\begin{array}{l}\text { Secondary forestry residues } \\
\text { South EU }\end{array}$ & 3.5 & 4.2 & 5.2 & 10.4 & 10.3 & 10.2 & 7.1 & 7.1 & 7.1 \\
\hline $\begin{array}{l}\text { Secondary forestry residues } \\
\text { West EU }\end{array}$ & 14.0 & 15.9 & 16.6 & 7.5 & 7.5 & 7.5 & 4.0 & 3.9 & 3.9 \\
\hline $\begin{array}{l}\text { Primary forestry residues } \\
\text { and stemwood NL }\end{array}$ & 4.9 & 5.3 & 5.8 & 4.1 & 4.1 & 4.1 & & & \\
\hline $\begin{array}{l}\text { Primary forestry residues } \\
\text { East EU }\end{array}$ & 30.2 & 31.7 & 29.9 & 9.1 & 9.4 & 9.3 & 6.5 & 7.1 & 6.8 \\
\hline $\begin{array}{l}\text { Primary forestry residues } \\
\text { North EU }\end{array}$ & 47.0 & 36.8 & 38.2 & 11.0 & 10.8 & 10.8 & 6.6 & 6.6 & 6.5 \\
\hline
\end{tabular}




\begin{tabular}{|c|c|c|c|c|c|c|c|c|c|}
\hline & \multicolumn{3}{|c|}{ Biomass availability (PJ) } & \multicolumn{3}{|c|}{$\begin{array}{l}\text { Cost of supply } \\
\text { (€/GJ) }\end{array}$} & \multicolumn{3}{|c|}{$\begin{array}{l}\text { of which transport costs } \\
\qquad(\mathrm{C} / \mathrm{GJ})\end{array}$} \\
\hline & 2010 & 2020 & 2030 & 2010 & 2020 & 2030 & 2010 & 2020 & 2030 \\
\hline $\begin{array}{l}\text { Primary forestry residues } \\
\text { South EU }\end{array}$ & 26.1 & 29.3 & 29.4 & 10.9 & 10.7 & 10.7 & 6.9 & 7.0 & 7.0 \\
\hline $\begin{array}{l}\text { Primary forestry residues } \\
\text { West EU }\end{array}$ & 45.4 & 36.4 & 37.9 & 8.0 & 7.9 & 7.9 & 4.1 & 4.0 & 4.0 \\
\hline $\begin{array}{l}\text { Wood waste } \\
\text { (incineration) }\end{array}$ & 17.2 & 17.2 & 21.3 & 21.3 & 4.4 & 4.4 & & & \\
\hline $\begin{array}{l}\text { Wood waste East EU } \\
\text { (incineration) }\end{array}$ & 2.8 & 2.8 & 5.0 & 5.0 & 9.4 & 9.4 & 6.6 & 6.4 & 6.4 \\
\hline $\begin{array}{l}\text { Wood waste North EU } \\
\text { (incineration) }\end{array}$ & 5.5 & 5.5 & 9.5 & 9.5 & 2.9 & 2.9 & 1.7 & 1.8 & 1.8 \\
\hline $\begin{array}{l}\text { Wood waste South EU } \\
\text { (incineration) }\end{array}$ & 2.0 & 2.0 & 3.0 & 3.0 & 8.5 & 8.5 & 4.9 & 4.9 & 4.9 \\
\hline $\begin{array}{l}\text { Wood waste West EU } \\
\text { (incineration) }\end{array}$ & 2.4 & 2.4 & 2.9 & 2.9 & 5.6 & 5.6 & 2.6 & 2.5 & 2.5 \\
\hline Landscape wood NL & 5.8 & 5.8 & 8.0 & 3.4 & 3.4 & 3.4 & & & \\
\hline Landscape wood East EU & 6.3 & 7.3 & 9.9 & 8.3 & 8.2 & 8.2 & 6.3 & 6.3 & 6.3 \\
\hline Landscape wood North EU & 6.5 & 7.9 & 10.4 & 8.6 & 8.6 & 8.6 & 6.2 & 6.3 & 6.3 \\
\hline Landscape wood South EU & 5.0 & 5.6 & 7.6 & 9.4 & 9.4 & 9.4 & 7.1 & 7.1 & 7.1 \\
\hline Landscape wood West EU & 7.5 & 8.7 & 9.0 & 6.9 & 6.9 & 6.9 & 4.7 & 4.7 & 4.7 \\
\hline Agricultural residues NL & 3.3 & 2.7 & 2.6 & 6.7 & 6.4 & 5.8 & & & \\
\hline $\begin{array}{l}\text { Agricultural residues East } \\
\text { EU }\end{array}$ & 14.0 & 13.9 & 13.4 & 8.9 & 8.7 & 8.5 & 6.1 & 6.1 & 6.1 \\
\hline $\begin{array}{l}\text { Agricultural residues North } \\
\text { EU }\end{array}$ & 8.2 & 7.7 & 8.1 & 8.8 & 8.5 & 8.2 & 4.9 & 5.0 & 5.0 \\
\hline $\begin{array}{l}\text { Agricultural residues South } \\
\text { EU }\end{array}$ & 6.0 & 5.4 & 5.5 & 9.4 & 9.4 & 9.2 & 7.2 & 7.2 & 7.2 \\
\hline $\begin{array}{l}\text { Agricultural residues West } \\
\text { EU }\end{array}$ & 17.8 & 18.0 & 18.8 & 7.4 & 7.1 & 7.1 & 3.8 & 3.8 & 3.8 \\
\hline Short rotation forestry NL & & 0.9 & 1.7 & & 9.9 & 9.5 & & & \\
\hline $\begin{array}{l}\text { Short rotation forestry East } \\
\text { EU }\end{array}$ & 0.0 & 7.3 & 8.4 & 7.4 & 9.2 & 9.0 & 5.4 & 7.2 & 6.7 \\
\hline $\begin{array}{l}\text { Short rotation forestry } \\
\text { North EU }\end{array}$ & 0.0 & 2.7 & 3.0 & 9.2 & 9.2 & 9.0 & 4.8 & 5.7 & 5.7 \\
\hline $\begin{array}{l}\text { Short rotation forestry } \\
\text { South EU }\end{array}$ & 0.0 & 2.6 & 3.0 & 13.6 & 17.9 & 17.4 & 6.5 & 7.3 & 7.3 \\
\hline $\begin{array}{l}\text { Short rotation forestry West } \\
\text { EU }\end{array}$ & 0.0 & 1.9 & 2.0 & 7.6 & 8.8 & 8.8 & 3.7 & 4.2 & 4.2 \\
\hline Perennial grasses NL & & 8.8 & 16.5 & & 7.0 & 6.8 & & & \\
\hline Perennial grasses East EU & 0.1 & 20.4 & 21.7 & 6.6 & 9.1 & 9.0 & 5.4 & 8.0 & 8.0 \\
\hline Perennial grasses North EU & 0.0 & 1.1 & 1.3 & 9.7 & 9.5 & 9.3 & 4.8 & 4.6 & 4.6 \\
\hline Perennial grasses South EU & 0.1 & 18.1 & 20.0 & 9.8 & 12.3 & 12.0 & 6.0 & 7.3 & 7.3 \\
\hline Perennial grasses West EU & 0.3 & 11.8 & 12.3 & 7.3 & 7.6 & 7.6 & 3.9 & 4.2 & 4.2 \\
\hline Other grasses NL & 2.43 & 2.54 & 2.60 & 1.4 & 1.3 & 1.3 & & & \\
\hline Other grasses East EU & 0.39 & 0.39 & 0.40 & 6.4 & 6.3 & 6.3 & 5.9 & 6.3 & 5.9 \\
\hline Other grasses North EU & 0.72 & 0.77 & 0.82 & 6.0 & 5.9 & 5.9 & 5.5 & 5.5 & 5.5 \\
\hline Other grasses South EU & 0.83 & 0.88 & 0.94 & 7.6 & 7.6 & 7.5 & 7.1 & 7.1 & 7.1 \\
\hline Other grasses West EU & 3.55 & 2.54 & 2.62 & 4.3 & 4.3 & 4.3 & 3.5 & 3.6 & 3.6 \\
\hline Sugar beet stubble NL & 1.76 & 1.44 & 1.48 & 1.6 & 1.7 & 1.6 & & & \\
\hline
\end{tabular}

a Cost-prices are estimated based on weighted average of feedstock categories listed under the second column and cost-prices as derived for roadside costs from the Biomass Policies / S2BIOM project (www.s2biom.eu). Low-grade feedstocks that are difficult to mobilize are excluded from the weighted average. Transport costs of EU supply determined based on wood chip logistic costs from NUTS2 regions to Rotterdam based on Hoefnagels et al. (2014a, 2014b). For EU sugar/starch crops global raw sugar price is used based on OECD/FAO (2014). For starch an additional cost component (starch hydrolysis to glucose) is applied. 
Finally, Figure 91 presents an illustration of a cost-supply curve for solid biomass in 2030 in the regional (Reg) and global (Glob) scenarios. In the figure it is shown that global biomass becomes cost competitive from domestic and EU resources at prices above $€ 135 / t_{\text {wpe }}$.

Cost-supply curbe solid biomass 2030

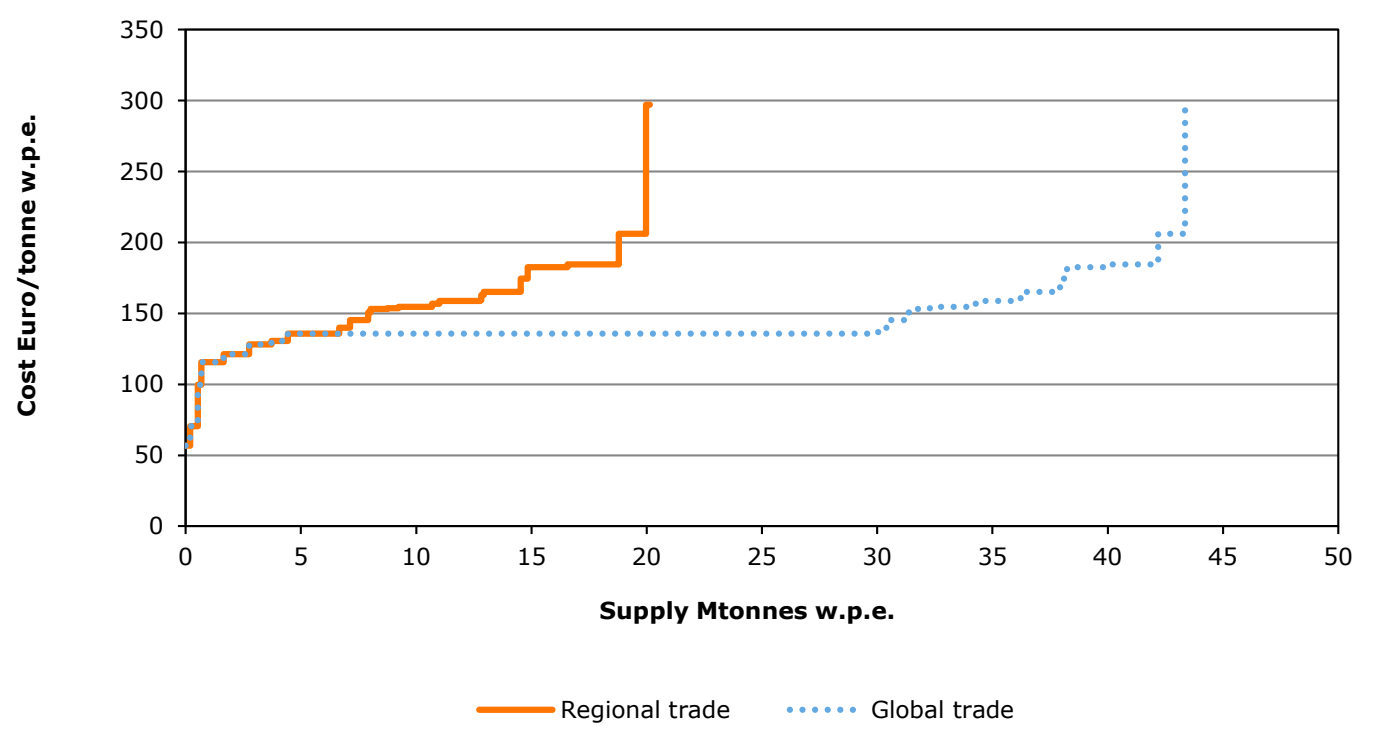

Figure 91 Cost-supply curve of solid biomass (short rotation forestry, agricultural residues, primary forestry residues, secondary forestry residues, perennial grasses) in regional and global trade scenarios in 2030 
Table 26

Emission factors used for domestic and regional (EU) biomass production per feedstock type based on JRC analysis according to the method set in COM(2010) 11 and SWD(2014) 259

\begin{tabular}{|c|c|c|}
\hline s2Biom feedstock & Proxy emission factor for & $\begin{array}{l}\text { Emission factor } \\
{\left[\mathrm{gCO}_{2} \mathrm{eq} . / \mathrm{MJfeed}\right]}\end{array}$ \\
\hline all_cereals & straw pellets & 5.1 \\
\hline Biodiesel_soya & rapeseed biodiesel & 29 \\
\hline Biodiesel_sunflower_seed & rapeseed biodiesel & 29 \\
\hline Bioethanol_durum_wheat & wheat ethanol & 23 \\
\hline Bioethanol_maize & wheat ethanol & 23 \\
\hline Bioethanol_oats & wheat ethanol & 23 \\
\hline Bioethanol_other_cereals & wheat ethanol & 23 \\
\hline Bioethanol_rey & wheat ethanol & 23 \\
\hline cattle_liquid & manure $^{d}$ & 45 \\
\hline \multicolumn{3}{|l|}{ cattle_solid } \\
\hline Energy_maize & maize digestate & 7.2 \\
\hline Forage_grass_cutting & agri residues & 0.9 \\
\hline grain_maize & agri residues & 0.9 \\
\hline \multicolumn{3}{|l|}{ HH_AnMixfood } \\
\hline \multicolumn{3}{|l|}{ HH_MSW } \\
\hline \multicolumn{3}{|l|}{ HH_Paper } \\
\hline \multicolumn{3}{|l|}{ HH_Vegetal } \\
\hline \multicolumn{3}{|l|}{ NACE_MSW } \\
\hline \multicolumn{3}{|l|}{ NACE_Paper } \\
\hline \multicolumn{3}{|l|}{ NACE_UFO } \\
\hline \multicolumn{3}{|l|}{ NACE_Vegetal } \\
\hline \multicolumn{3}{|l|}{ Nace_Wood } \\
\hline osr_sunflower & rapeseed biodiesel $^{\mathrm{b}}$ & 29 \\
\hline other_industrial_residues & wood chips from industry residues & 0.3 \\
\hline pig_liquid & manure & 45 \\
\hline \multicolumn{3}{|l|}{ pig_solid } \\
\hline Poplar & wood chips from SRC (poplar, fertilized) & 3.9 \\
\hline \multicolumn{3}{|l|}{ poultry_solid } \\
\hline Res_chips_pellets & wood chips from forest residues & 1.6 \\
\hline Res_fuel & wood chips from forest residues & 1.6 \\
\hline Road_side_verges & agri residues (high/low density) & 0.9 \\
\hline RW_fuel & wood chips from stemwood & 0.0014 \\
\hline saw_dust & wood chips from industry residues & 0.3 \\
\hline sawmill_byprod & wood chips from industry residues & 0.3 \\
\hline \multicolumn{3}{|c|}{ a Converted to feedstock emissions using $1.7 \mathrm{MJ}_{\text {feed }} / \mathrm{MJ}_{\text {fuel }}$ efficiency, excluding allocation for by-products. } \\
\hline
\end{tabular}




\section{Conversion technologies}

The tables below present the technology portfolio available in MARKAL-NL-UU for the sectors electricity/heat, transport fuels and chemical industry.

\section{Table 27}

Technology portfolio of the electricity and heat sector in MARKAL-NL-UU

\begin{tabular}{|c|c|c|}
\hline Fossil conversion & Biomass conversion & Other renewable conversion \\
\hline \multicolumn{3}{|l|}{ Electricity $^{b}$} \\
\hline Gas turbine & Pulverized coal - biomass co-firing & Off-shore wind \\
\hline $\begin{array}{l}\text { Integrated gasification combined cycle - } \\
\text { coal gasification }\end{array}$ & $\begin{array}{l}\text { Gas engines - small scale } \\
\text { biogas/landfill gas engines }\end{array}$ & Hydropower \\
\hline \multicolumn{3}{|l|}{ Nuclear } \\
\hline Natural gas combined cycle CHP & \multicolumn{2}{|l|}{ Biogas $\mathrm{CHP}^{\mathrm{d}, \mathrm{e}}$} \\
\hline Gas turbine CHP - natural gas, landfill gas & \multicolumn{2}{|l|}{$\begin{array}{l}\text { Integrated gasification combined } \\
\text { cycle CHP - biomass co-gasification }\end{array}$} \\
\hline Steam turbine CHP & \multicolumn{2}{|l|}{ MSWI - organic waste fraction ${ }^{f}$} \\
\hline \multicolumn{3}{|l|}{ MSWI - fossil waste fraction ${ }^{f}$} \\
\hline \multicolumn{3}{|l|}{ Heat $^{\text {d }}$} \\
\hline \multirow[t]{3}{*}{ Natural gas heat ${ }^{g}$} & \multicolumn{2}{|l|}{ Industrial biomass boilers } \\
\hline & \multicolumn{2}{|l|}{ Wood stoves (fuelwood) } \\
\hline & \multicolumn{2}{|l|}{ Green gas (biogas upgrade) } \\
\hline
\end{tabular}

a Production costs of electricity and co-generation technologies have been updated by (Brouwer et al., 2015).

b All large-scale electricity production technologies can be coupled with CCS. Exceptions are dedicated biomass steam cycle plants and municipal solid waste incinerator (MSWI).

c Electricity and/or heat is also co-produced by combined heat and power (CHP) units of transport fuel or chemical conversion technologies. These are not included in this table.

d Added in the present study.

e Upgrade of biogas to synthetic natural gas is also included.

f MSWI are characterized as one technology. In this table fossil and organic fraction of municipal solid waste are referred to separately for categorization purposes.

$\mathrm{g}$ Natural gas-based heat is implicitly included (i.e. without incorporating cost-structures in detail) by assuming a process efficiency of $90 \%$, which is representative of industrial heat generation in member-countries of the Organisation for Economic Co-operation and Development (OECD) (Saygin et al., 2014). This is a simplification as efficiencies may vary per sector (within industry or across other end-users such as households) or fuel type. Furthermore, input fuels may vary, however, for the Netherlands, natural gas is the main energy carrier for heat. 
Table 28

Technology portfolio of the $t$ sector in MARKAL-NL-UU

\begin{tabular}{|c|c|c|}
\hline \multicolumn{3}{|l|}{ TRANSPORT FUELS } \\
\hline Fossil conversion & Biomass conversion & Other renewable conversion \\
\hline \multicolumn{2}{|l|}{ Road transport } & \multirow{11}{*}{$\begin{array}{l}\text { Renewable electricity for electric } \\
\text { vehicles }\end{array}$} \\
\hline Diesel & $\begin{array}{l}\text { Second-generation ethanol (dilute acid, steam } \\
\text { explosion, liquid hot water as pre-treatments) }\end{array}$ & \\
\hline & FT diesel and gasoline & \\
\hline & Methanol & \\
\hline & DME & \\
\hline & Gasoline from methanol-to-olefins & \\
\hline \multicolumn{2}{|l|}{ Aviation $^{a}$} & \\
\hline \multirow[t]{4}{*}{ Kerosene } & Hydrotreated biodiesel (HEFA/HRD) & \\
\hline & FT diesel to jet & \\
\hline & Renewable diesel (hydrothermal liquefaction) & \\
\hline & Diesel catalytic pyrolysis & \\
\hline
\end{tabular}

a Biomass conversion technologies for aviation also applicable to road transport. 
Table 29

Technology portfolio of the transport fuel sector in MARKAL-NL-UU

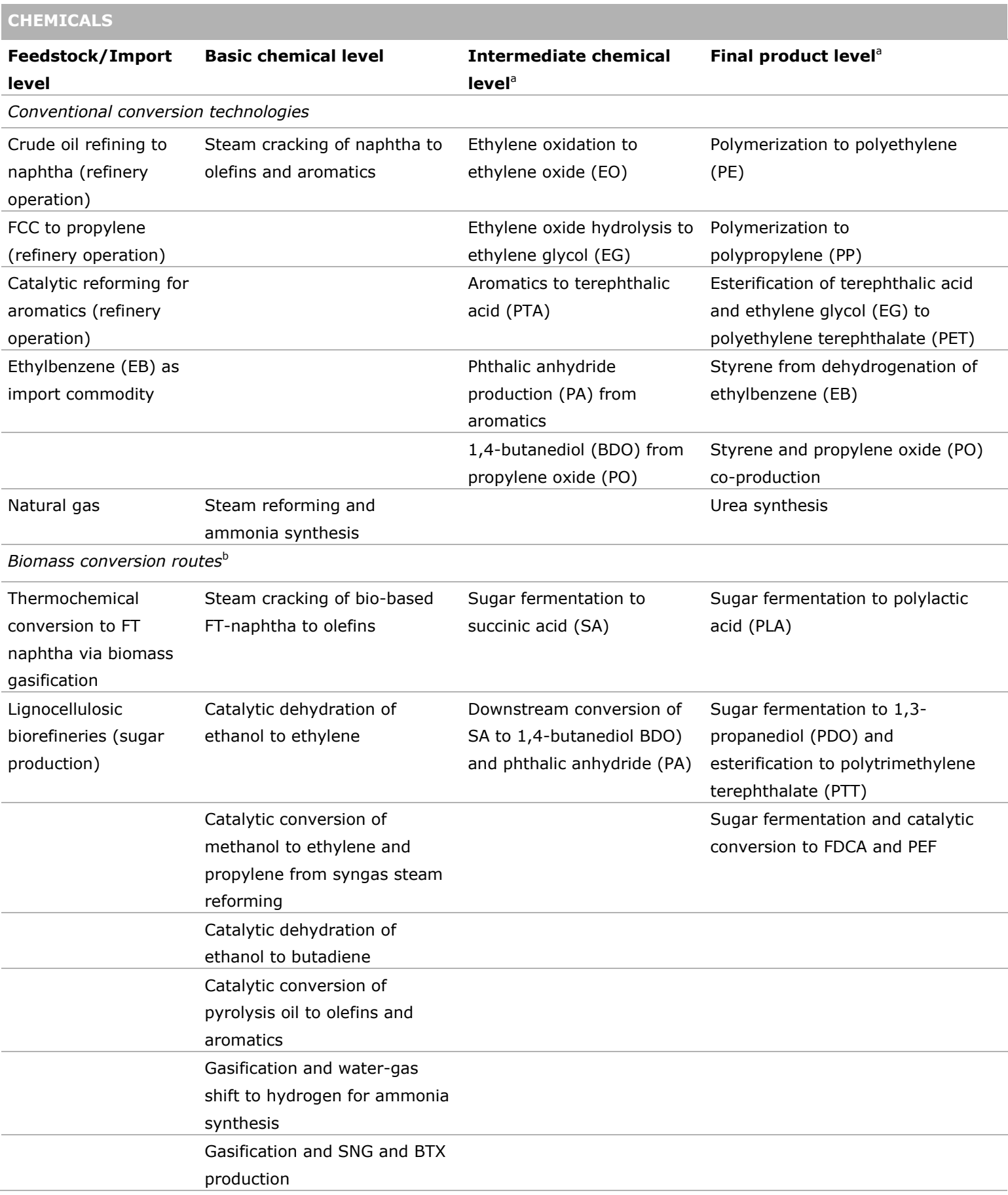

a In this table, downstream conversion technologies at an intermediate and final product level that are reported under conventional conversion technologies are common for chemically equivalent bio-based feedstocks such as olefins and aromatics.

b Another conversion technology that is included in MARKAL-NL-UU is methanol production from biomass, which provides feedstock to methanol-to-olefins conversion technologies. This technology is based on (van Vliet et al., 2011).

The two tables below present the cost-structures of key technologies of the road transport and electricity sectors incorporated in MARKAL-NL-UU. Additional technical parameters and other inputs are presented in Table 31 to Table 35. 
Table 30

Inputs, outputs, costs and emissions of conversion technologies used in MARKAL-NL-UU (van Vliet et al., 2011) Cost-data are in $€ 2007$

\begin{tabular}{|c|c|c|c|c|}
\hline Designation Feedstock Outputs (fuel: GJout/GJin) & $\begin{array}{l}\text { Investment } \\
\text { (c/kWin) }\end{array}$ & $\begin{array}{l}\text { O\&M } \\
(c / k W i n / y)\end{array}$ & $\begin{array}{l}\text { Variable } \\
\text { (C/GJin) }\end{array}$ & Emissions \\
\hline
\end{tabular}

to air to CCS

FT

\begin{tabular}{|c|c|c|c|c|c|c|}
\hline F_BF_10 & Biomass & $\begin{array}{l}\text { FT diesel: } 0.429 \text {, electricity: } \\
0.064 \text {, } \\
\text { FT petrol: } 0.076\end{array}$ & 933 & 40 & 69 & 0 \\
\hline
\end{tabular}

\begin{tabular}{|c|c|c|c|c|c|c|}
\hline \multicolumn{7}{|l|}{ Hydrogen } \\
\hline F_BH_20 & Biomass & $\mathrm{H} 2: 0.683$, electricity: 0.048 & 600 & 27 & 90 & 0 \\
\hline F_BH_20_CC & Biomass & $\mathrm{H} 2: 0.683$, electricity: 0.017 & 628 & 28 & 1 & 89 \\
\hline F_NH_20_CC & Natural gas & $\mathrm{H} 2: 0.7$, electricity: 0.019 & 472 & 21 & 2 & 51 \\
\hline F_NH_10_N & Natural gas & $\mathrm{H} 2: 0.737,: 0$ & 554 & 362 & 56 & 0 \\
\hline \multicolumn{7}{|l|}{ Methanol } \\
\hline F_BM_20 & Biomass & $\begin{array}{l}\text { methanol: } 0.54 \text {, electricity: } \\
0.092\end{array}$ & 546 & 22 & 53 & 0 \\
\hline F_BM_20_CC & Biomass & $\begin{array}{l}\text { methanol: } 0.54 \text {, electricity: } \\
0.076\end{array}$ & 546 & 22 & 7 & 46 \\
\hline \multicolumn{7}{|l|}{ DME } \\
\hline F_BD_20_CC & Biomass & DME: 0.554 , electricity: 0.077 & 570 & 23 & 7 & 46 \\
\hline \multicolumn{7}{|l|}{ Oil refining } \\
\hline F_OP_00 & Crude oil & petrol: 0.914 & & & 7 & 0 \\
\hline F_OD_00 & Crude oil & diesel: 0.897 & & & 8 & 0 \\
\hline
\end{tabular}


Table 31

Technical and economic parameters of electricity generating technologies modelled in MARKAL-NL-UU (van den Broek et al., 2011). Costs are given in $€ 2007$

\begin{tabular}{|c|c|c|c|c|}
\hline Cost parameter & Technology & 2010 & 2020 & 2030 \\
\hline \multirow{7}{*}{ Investment costs (in $€ / \mathrm{kW}$ ) } & PC & 1598 & 1487 & 1448 \\
\hline & NGCC-CCS & 1146 & 1014 & 938 \\
\hline & PC-CCS & 2546 & 2328 & 2110 \\
\hline & Wind onshore & 1151 & 1090 & 1085 \\
\hline & Wind offshore & 3211 & 2269 & 1909 \\
\hline & Nuclear & 2652 & 2652 & 2652 \\
\hline & PV & 1947 & 1324 & 1045 \\
\hline \multirow{7}{*}{ Fixed $O \& M$ costs (in $€ / k W$ ) } & NGCC-CCS & 33 & 24 & 22 \\
\hline & PC-CCS & 95 & 81 & 75 \\
\hline & IGCC-CCS & 92 & 76 & 70 \\
\hline & Wind onshore & 17 & 17 & 17 \\
\hline & Wind offshore & 69.5 & 58.1 & 48.6 \\
\hline & Nuclear & 66 & 66 & 66 \\
\hline & PV & 19.8 & 18.5 & 17.3 \\
\hline \multirow[t]{4}{*}{ Variable O\&M costs (in $€ / G J$ ) } & NGCC & 0.02 & 0.02 & 0.02 \\
\hline & Wind offshore & 0 & 0 & 0 \\
\hline & Nuclear & 0.69 & 0.69 & 0.69 \\
\hline & PV & 0 & 0 & 0 \\
\hline \multirow[t]{6}{*}{ Efficiency (in \%) } & NGCC & 58 & 60 & 63 \\
\hline & PC & 46 & 49 & 52 \\
\hline & IGCC & 46 & 50 & 53 \\
\hline & NGCC-CCS & 49 & 52 & 56 \\
\hline & PC-CCS & 36 & 40 & 44 \\
\hline & IGCC-CCS & 38 & 44 & 48 \\
\hline
\end{tabular}




\section{Table 32}

Technical and economic parameters of CHP technologies modelled in MARKAL-NL-UU (excluding units for district heating) (van den Broek et al., 2011) Costs are given in € 2007

\begin{tabular}{|c|c|c|c|c|c|c|c|}
\hline & \multicolumn{7}{|c|}{ Efficiency } \\
\hline NGCC-CHP new & 43 & 31 & 1040 & 0.78 & 67 & & $<250$ \\
\hline Steam turbine small & 10 & 74 & 471 & 0.56 & 38 & 0.3 & $\sim 15$ \\
\hline $\begin{array}{l}\text { Gas turbine-CHP new } \\
\text { large }\end{array}$ & 28 & 61 & 971 & 0.53 & 75 & & $\sim 45$ \\
\hline Gas turbine-CHP small & 25 & 64 & 1470 & 1.1 & 75 & 0.3 & $\sim 8$ \\
\hline Gas engine-CHP existing & 41 & 49 & 550 & 0.74 & 46 & 1.8 & $<2$ \\
\hline
\end{tabular}

\section{Table 33}

Location factors in reference to Europe (Broeren et al., 2014)

\begin{tabular}{ll} 
Location factor & Region \\
\hline 118.2 & Asia Pacific (Japan, Korea) \\
\hline 100.0 & Europe (France, Germany, Italy, Netherlands, Poland, UK) \\
\hline 90.9 & North America (United States and Canada) \\
\hline 11.8 & China and India \\
\hline 113.6 & Middle East and Africa (Saudi Arabia, Iran, Kuwait, Egypt) \\
\hline 113.6 & Other Developing Asia (Indonesia, Thailand, Malaysia, Singapore, Taiwan) \\
\hline 113.6 & South America (Brazil, Venezuela, Argentina, Colombia, Trinidad, Chile) \\
\hline
\end{tabular}

\section{Table 34}

Fixed cost components based on (Hermann \& Patel, 2007)

\begin{tabular}{lll} 
Fixed cost component & Factor & \\
Operating supplies & $10 \%$ & of operating labour \\
\hline Maintenance supplies & $1.5 \%$ & of ISBL \\
\hline Maintenance labour & $2.5 \%$ & of ISBL \\
\hline Laboratory labour & $13 \%$ & of operating labour \\
\hline Taxes and insurance & $3 \%$ & of ISBL and OSBL \\
\hline Plant overhead & $80 \%$ & of total labour \\
\hline G\&A & $6 \%$ & of plant gate cost (variable other fixed costs) \\
\hline
\end{tabular}

The figure below shows the technology portfolio, the capacities and the emergence year of technologies in the two technology development scenarios developed for the MEV II study and as applied in MARKAL-NL-UU. 


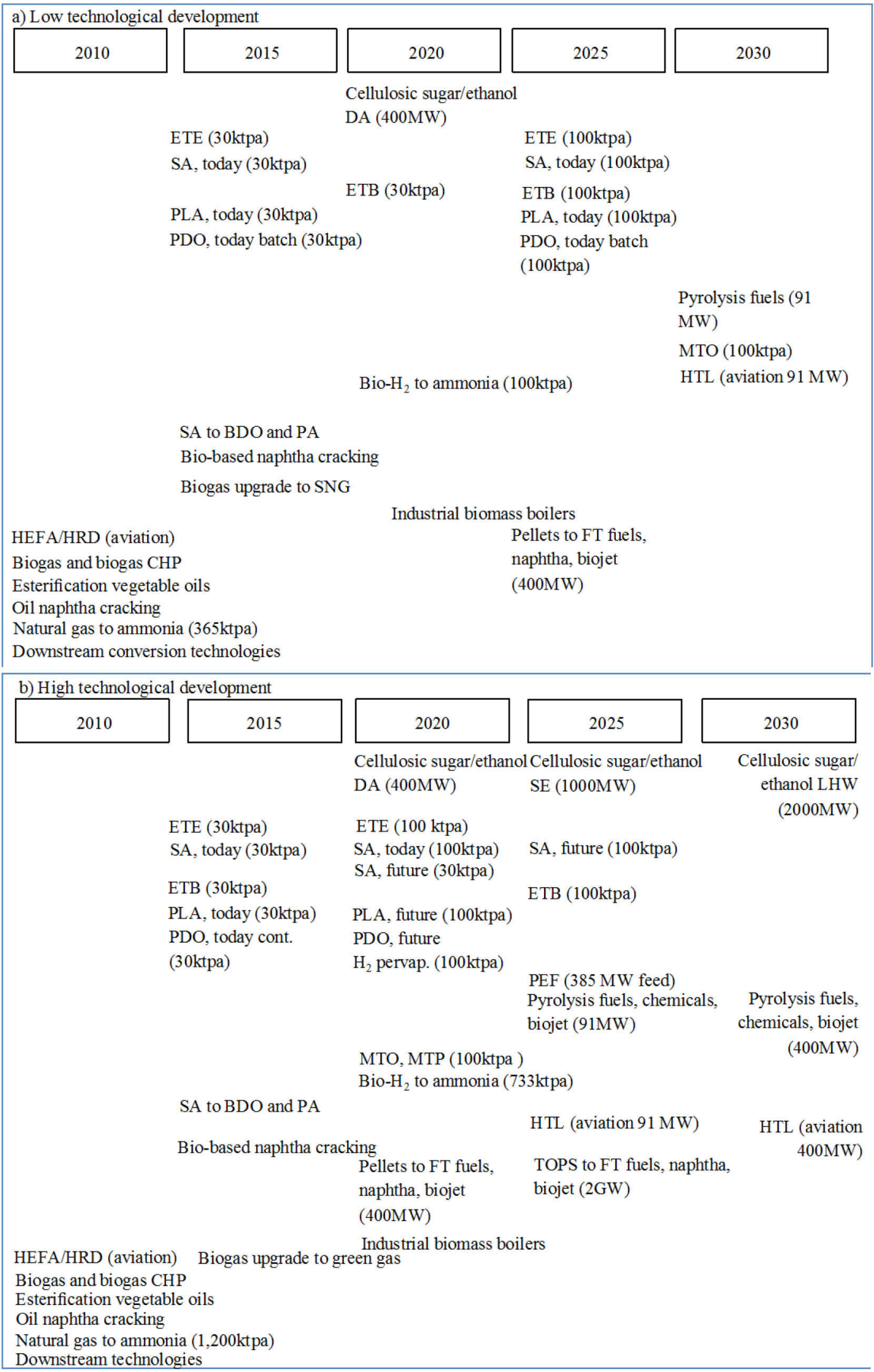

Figure 92 Technology portfolio, capacities and start year variation between the two technology development scenarios of MEV II as applied in MARKAL-NL-UU 


\section{Table 35}

Incremental yield and autonomous annual energy efficiency improvements in chemical conversion technologies of the low and high technology development scenarios

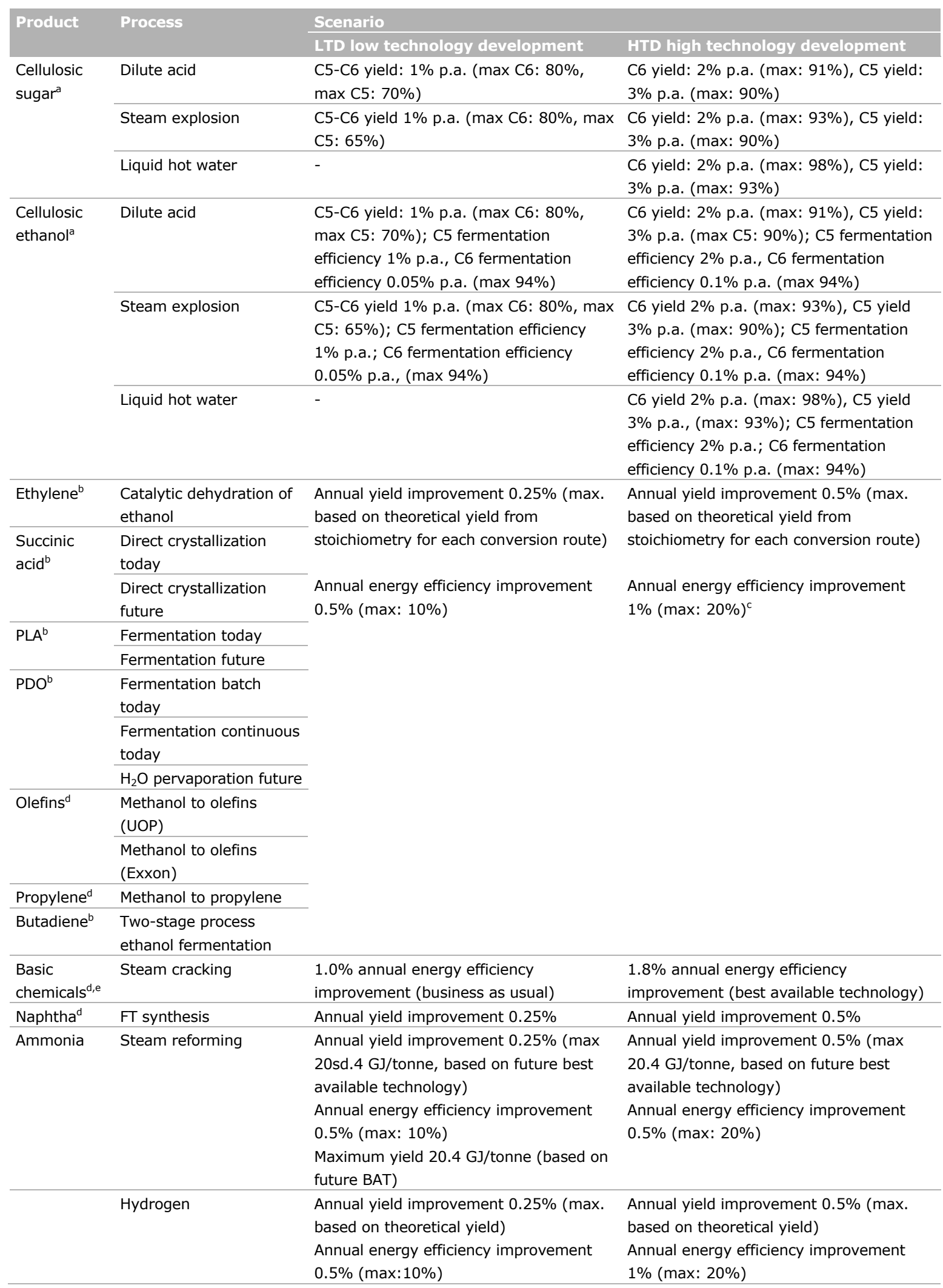

a All improvements assumed from 2015 onward. Core technology components are scaled due to higher sugar output based on the Excel model from Hamelinck et al. (2005).

b For today's technologies, improvements are assumed from 2015 onwards. For future technologies, improvements are assumed from 2020 onwards.

c This is in line with the Dutch Energy Agreement in which the annual savings in energy consumption are expected to be $1.5 \%$ (SER, 2013).

d Improvements assumed from 2010 onward.

e Estimate based on (Saygin et al., 2013). 
Table 36

Production capacity of chemicals in the Netherlands

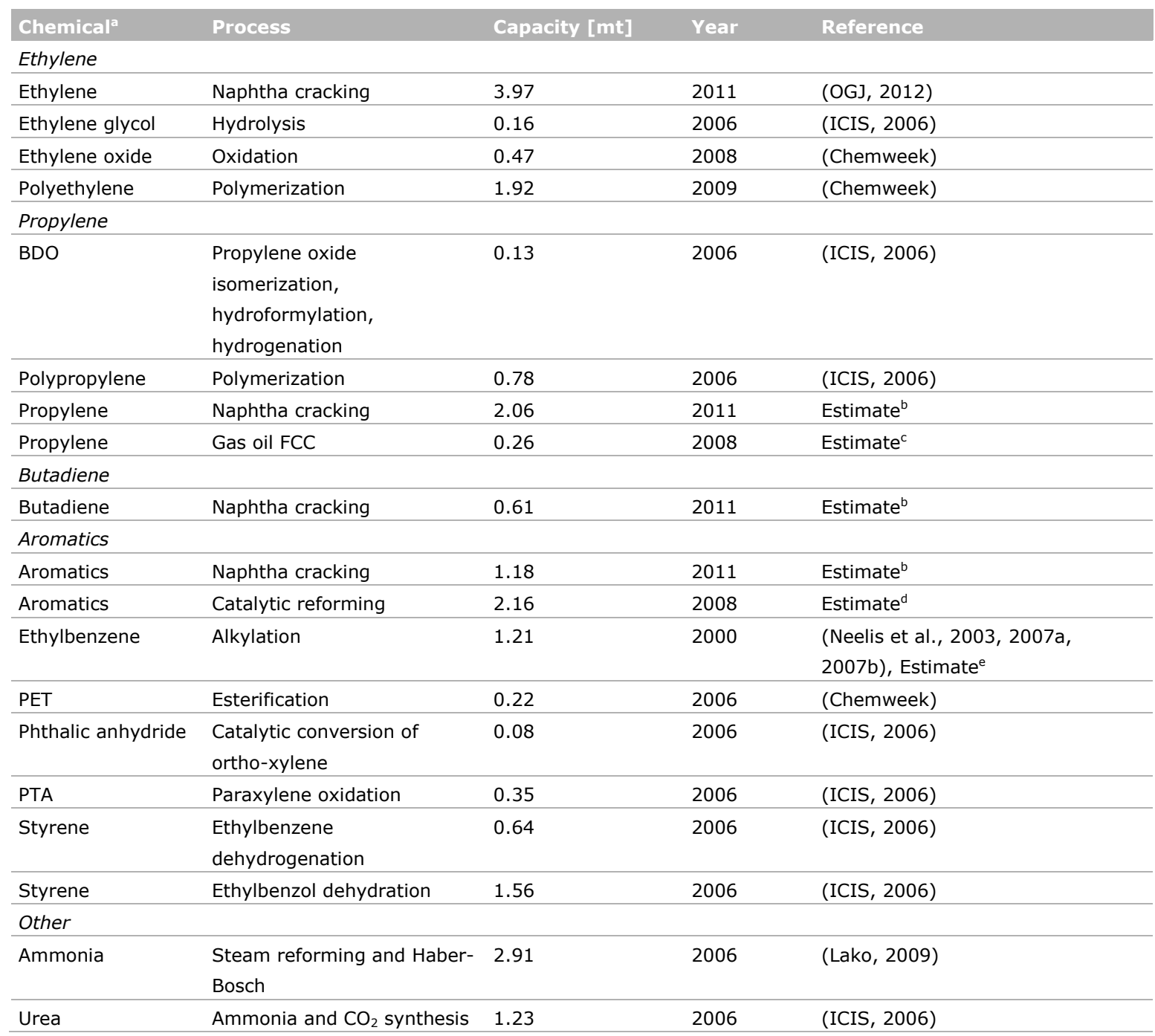

a Chemicals are categorized under the key basic chemical they are produced from. Note, however, that most intermediate chemicals or final products are synthesized from different basic chemicals.

b Based on ultimate yields of naphtha steam crackers in (Neelis et al., 2005).

c Based on FCC capacity (OGJ, 2009) assuming a $10.5 \%$ wt fresh feed (Couch et al., 2007). Production volume estimated based on $80 \%$ capacity utilization (VNPI, 2015).

d Based on catalytic reforming capacity (OGJ, 2009), $0.85 \mathrm{t}$ reformate/t heavy naphtha, $2 \mathrm{t}$ reformate/t of catalytic reforming products and $68 \%$ aromatics yield (Neelis et al., 2003, 2007a, 2007b).

e Production capacity of 2000 assumed the same for 2006 . 
Table 37

Growth rates of chemicals assumed in this study estimated from IEA (2009)

$2006-2030$
High

a For IEA (2009a) the growth rate represents methanol and is estimated only for Germany.

Table 38

Process yields of basic chemicals to derivatives based on (Neelis et al., 2003, 2007a, 2007b)

\begin{tabular}{llll}
\hline$t$ basic chemical/t product & $\mathrm{t}$ ethylene & $\mathrm{t}$ propylene & $\mathrm{t}$ aromatics \\
Polyethylene & 1.035 & 0 & 0 \\
\hline Ethylene oxide & 0.88 & 0 & 0 \\
\hline Ethylene oxide for PET & 0.24 & 0 & 0 \\
\hline Ethylene glycol & 0.71 & 0 & 0 \\
\hline Ethylene glycol for PET & 0.24 & 0 & 0 \\
\hline PTA & 0 & 0 & 0.68 \\
\hline PTA for PET & 0 & 0 & 0.58 \\
\hline PET & 0.24 & 0 & 0.40 \\
\hline Polypropylene & 0 & 1.01 & 0 \\
\hline Ethylbenzene & 0.27 & 0 & 0.76 \\
\hline Styrene & 0.29 & 0.21 & 0.78 \\
\hline Ethylbenzene for styrene & 0.31 & 0 & 0.79 \\
\hline Propylene and ethylbenzene for styrene & 0.32 & 0.34 & 0.90 \\
\hline Propylene oxide (by-product) & Formed as by-product & \\
\hline Propylene oxide for BDO & 0.84 t PO/t BDO & 0.92 \\
\hline Phthalic anhydride & 0 & 0 & 0 \\
\hline
\end{tabular}

a Based on 0.39 t PO/t EB via the ethyl benzol route.

Table 39

Residual capacity of basic chemicals defined in MARKAL-NL-UU

\begin{tabular}{ll} 
Basic chemical & Residual capacity in 2010 [mt] \\
Ethylene & 1.17 \\
\hline Propylene & 0.63 \\
\hline Butadiene & 0.60 \\
\hline Ethylene glycol & 0.09 \\
\hline Terephthalic acid & 0.17 \\
\hline Ammonia & 2.38
\end{tabular}

\section{Table 40}

Lower heating values of chemicals used for comparing energy with non-energy uses

\begin{tabular}{ll} 
Product & LHV $[\mathrm{MJ} / \mathrm{kg}]$ \\
\hline PLA & 18 \\
\hline PDO* & 18 \\
\hline PEF* & 42.5 \\
\hline Olefins & 12.3 \\
\hline Aromatics & 45 \\
\hline EB & 40.5 \\
\hline$*$ assumed & 42.5 \\
\hline
\end{tabular}


Table 41

Categorization of feedstocks in Sankey diagrams (Section 4.1.5.4)

\begin{tabular}{ll} 
Feedstock category and origin & Feedstock type \\
Crops NL & Sugar, starch, perennial grasses, oil crops, additional co-digestate \\
\hline Crops EU & Sugar, starch, perennial grasses, oil crops \\
\hline Crop residues NL & Grain crop residues, sugar beet stubble, other grasses \\
\hline Crop residues EU & Grain crop residues, other grasses \\
\hline Wood crops NL & Wood crops (willow, poplar) \\
\hline Wood crops EU & Wood crops (willow, poplar) \\
\hline Forestry products and residues NL & Primary forestry residues, secondary forestry residues, fuelwood, \\
\hline Forestry products and residues NL & landscape carewood, incineration wood waste, stemwood \\
\hline Wood pellets NL & $\begin{array}{l}\text { Primary forestry residues, secondary forestry residues, fuelwood, } \\
\text { landscape carewood, incineration wood waste, stemwood }\end{array}$ \\
\hline Waste NL & Wood pellets \\
\hline UCO & $\begin{array}{l}\text { MSW, solid manure, other digestible waste, used cooking oil, common } \\
\text { sludges, liquid manure }\end{array}$ \\
\hline Biofuels GL & Used cooking oil \\
\hline
\end{tabular}




\section{Methodology}

Figure 93 shows the detailed structure of the conversion technologies for the chemical industry module in MARKAL NL-UU.

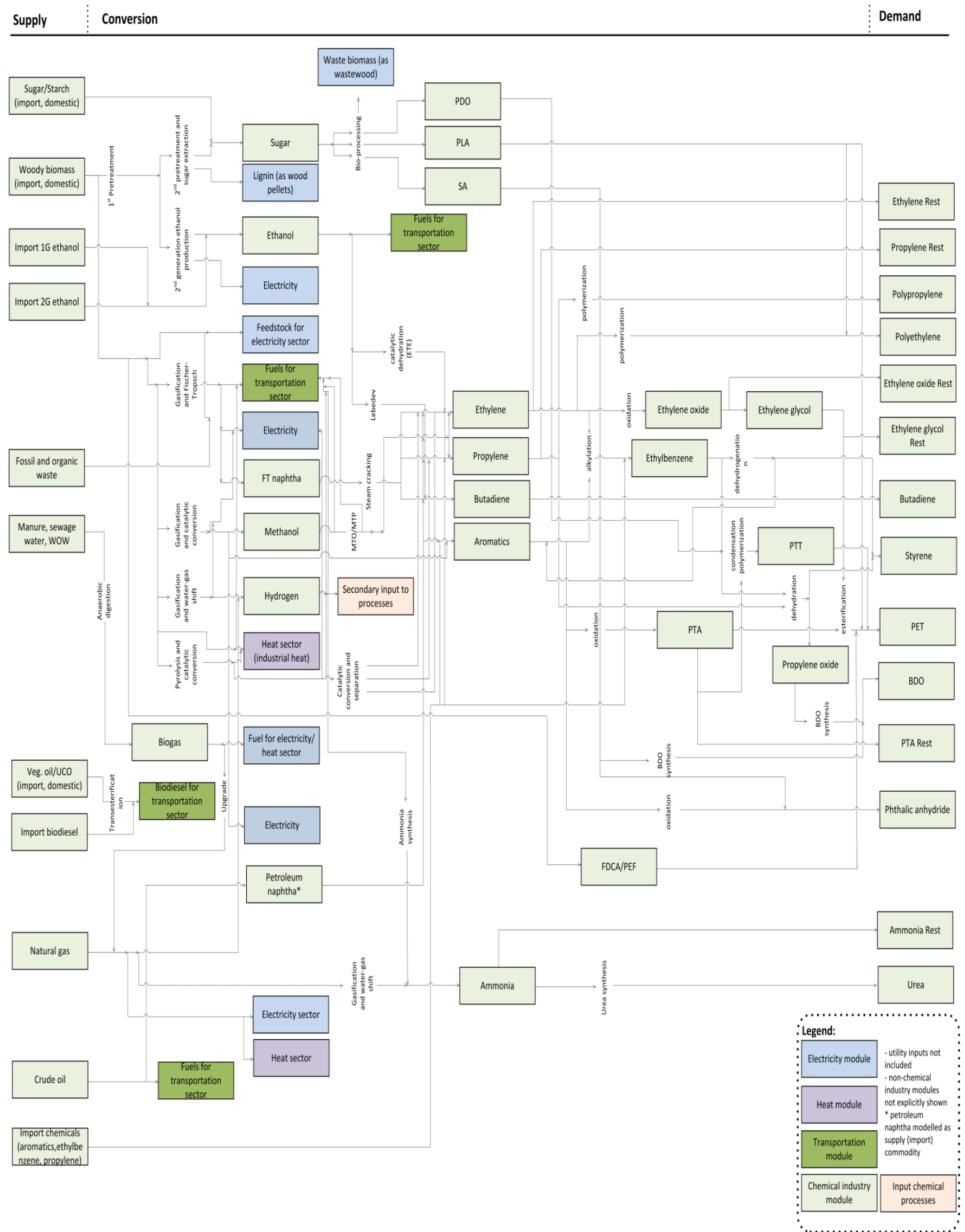

Figure 93 Detailed structure of the chemical industry module (conversion) of MARKAL-NL-UU as expanded for the MEV II study

Figure 94 presents in an aggregated manner the method applied in the chemical industry module to allow competition of biomass conversion technologies in different steps of the chemical industry's production chain. 


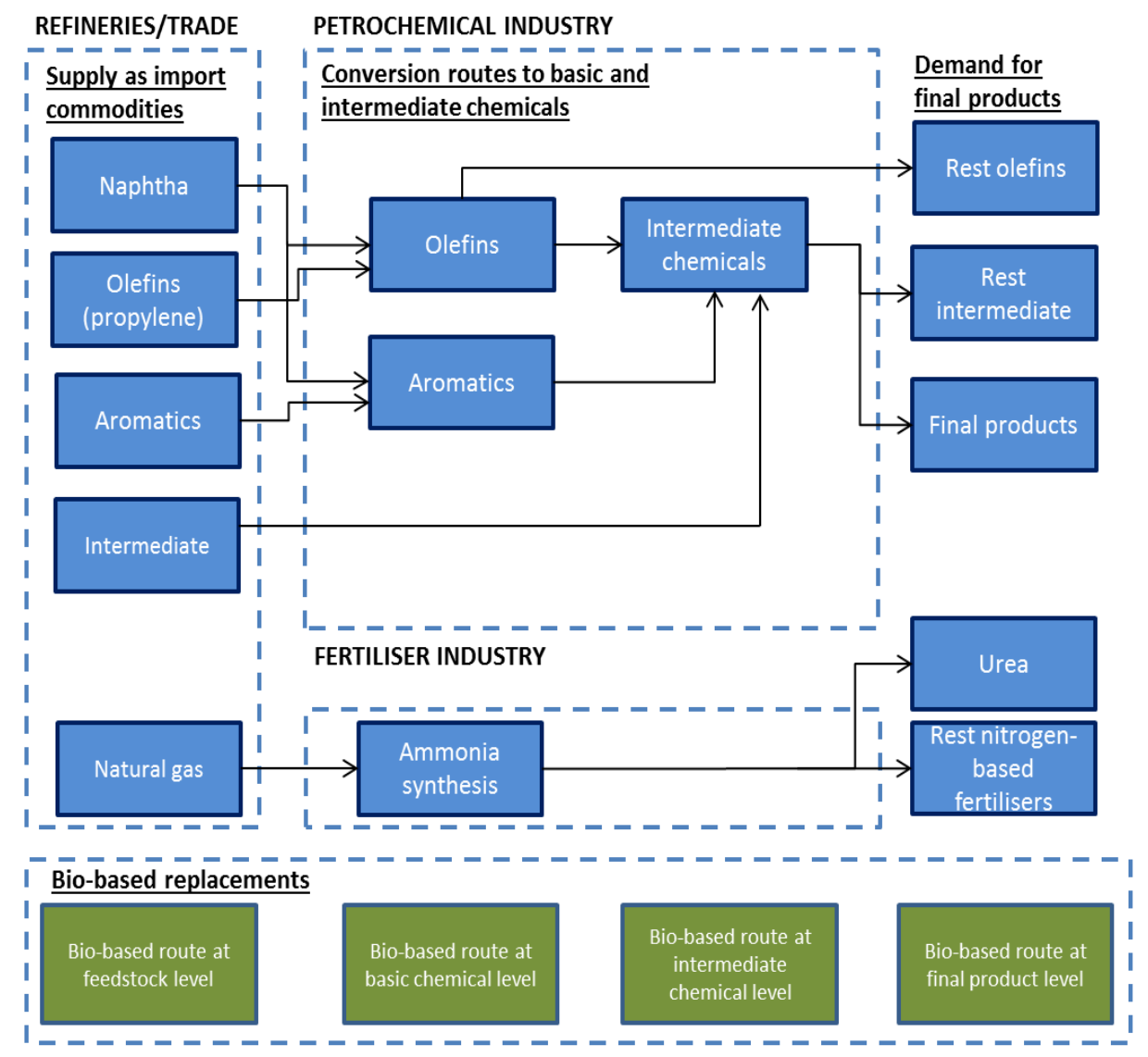

Figure 94 Representation of petrochemicals in MARKAL-NL-UU along with alternative bio-based chemicals

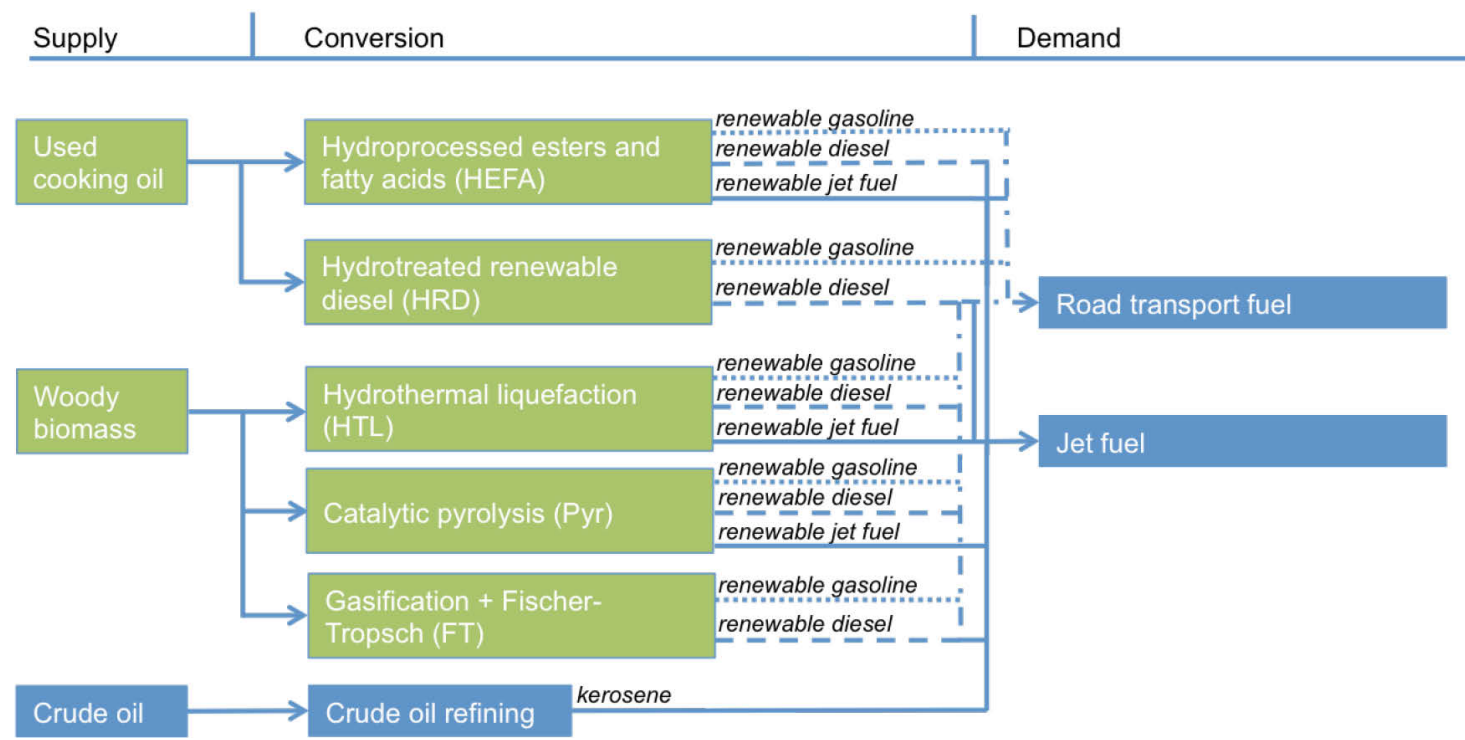

Figure 95 Representation of aviation sector in MARKAL-NL-UU (note: LPG has been assumed as renewable gasoline and is converted on the basis of lower heating values) 


\section{Additional analysis}

\section{Total system costs from bottom-up modelling with MARKAL-NL-UU}

MARKAL-NL-UU provides total system costs (i.e. investment costs spread over the total life time of the deployed technologies, variable and fixed O\&M costs) from 2000 to the end of the optimization period (2030). To estimate total system costs for the period 2010-2030 we apply the following method:

- All results include costs for the period 2000-2009 as these are also included in the optimization of MARKAL-NL-UU;

- MARKAL-NL-UU provides results for 5-year intervals, however, total system costs up to 2030 need to include also intermediate years. We assume that costs for intermediate years are the average costs of the start and end year of the iteration period. For example, costs for years 2011 up until 2014 are: $(\operatorname{Costs}(2010)+$ Costs $(2015)) / 2=$ Costs $(2011)=$ Costs $(2012)=$ Costs $(2013)=$ Costs (2014).

For comparison across scenarios, the most valuable indicator is the difference between total system costs on an annual basis. In Figure 96 we present additional costs of selected scenarios compared to the reference scenarios. These costs were derived by deducting total system costs for the period 2000-2030 and dividing by 31 years.

- Additional costs are highest for $\mathrm{CO}_{2}$ cap scenarios (above $€ 1$ bn in the RegLowTech scenario). $\mathrm{CO}_{2}$ cap scenarios are the only scenarios to which a target is applied (40\% emission reduction) thereby providing a consistent comparison across the scenarios. The comparison between GlobLowTech and RegHighTech shows that high technological deployment and accessing cheap resources to meet the same target cost roughly the same;

- Enforced manure treatment costs approximately $€ 430-470 \mathrm{~m}$ per year due to additional costs for codigestate and the deployment of digestion and biogas upgrade technologies;

- Aviation scenarios are compared not against the reference scenarios but against scenarios that do not set a blending target for biojet fuels. Such scenarios add as much as $€ 1-20 \mathrm{~m}$ per year to total system costs. These costs are low on the one hand due to the low levels of the blending target $(3.8 \%)$ and on the other hand to strong synergies of aviation technologies with road transport fuel technologies.

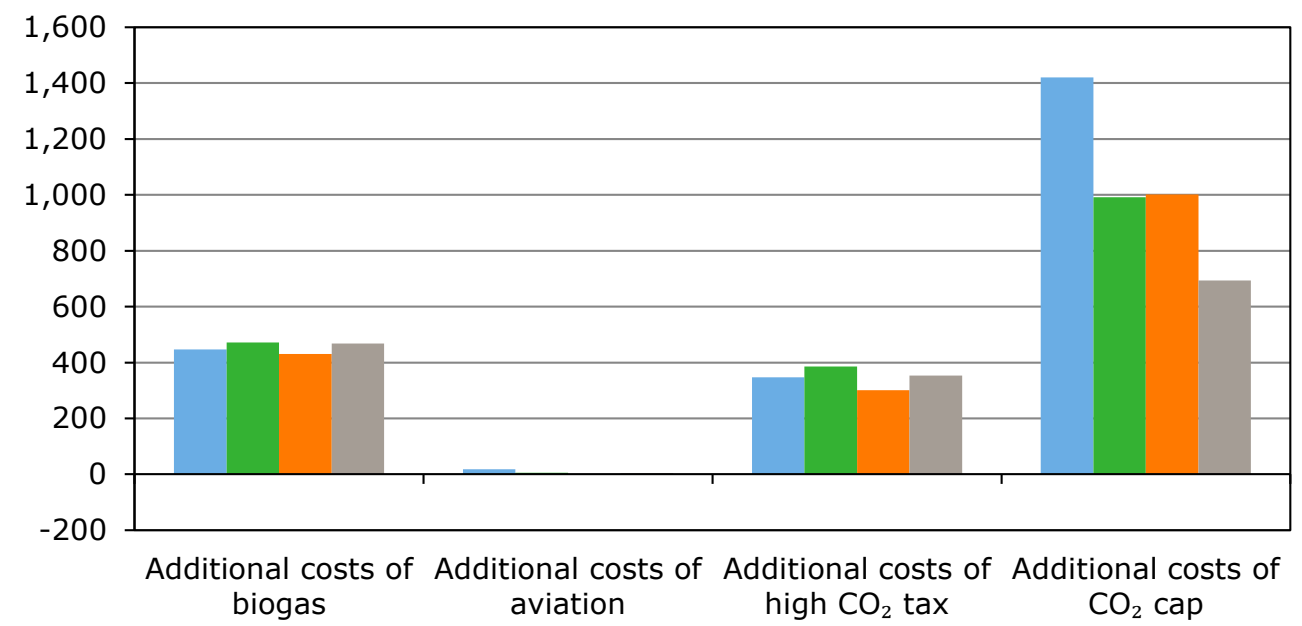

$$
\text { RegLowTech } \quad \text { GlobLowTech } \quad \text { RegHighTech } \quad \text { GlobHighTech }
$$

Figure 96 Additional costs of selected scenarios compared to the reference scenarios on an annual basis 
LEI Wageningen UR

\section{P.O. Box 29703}

2502 LS The Hague

The Netherlands

$\mathrm{T}+31(0) 703358330$

E publicatie.lei@wur.nl

www.wageningenUR.nl/en/lei

REPORT

LEI 2016-001
LEI Wageningen UR is one of the world's leading independent socio-economic research institutes. LEI's unique data, models and knowledge offer clients insight and integrated advice on policy and decision-making in an innovative manner, and ultimately contribute to a more sustainable world. LEI is part of Wageningen UR (University and Research centre), forming the Social Sciences Group together with the Department of Social Sciences and Wageningen UR Centre for Development Innovation.

The mission of Wageningen UR (University \& Research centre) is 'To explore the potential of nature to improve the quality of life'. Within Wageningen UR, nine specialised research institutes of the DLO Foundation have joined forces with Wageningen University to help answer the most important questions in the domain of healthy food and living environment. With approximately 30 locations, 6,000 members of staff and 9,000 students, Wageningen UR is one of the leading organisations in its domain worldwide. The integral approach to problems and the cooperation between the various disciplines are at the heart of the unique Wageningen Approach. 

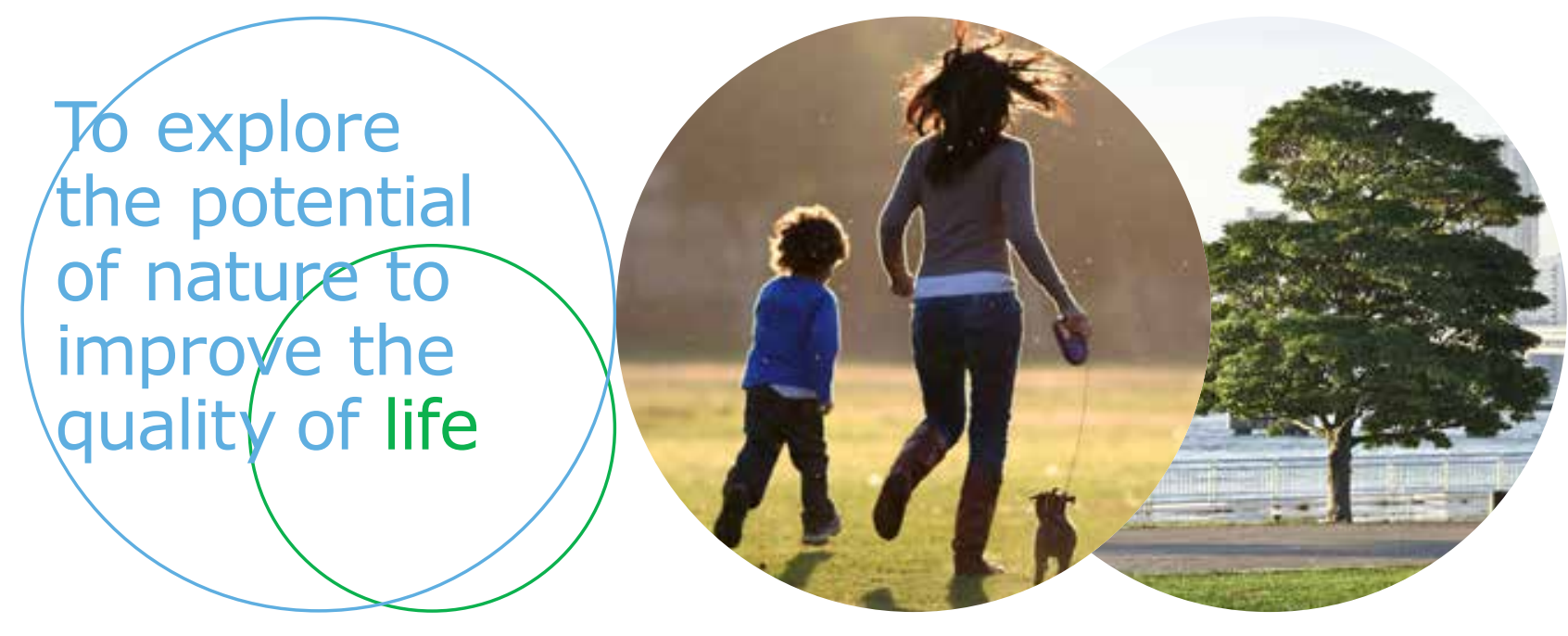

LEI Wageningen UR

Postbus 29703

2502 LS Den Haag

E publicatie.lei@wur.nl

www.wageningenUR.nl/lei

REPORT

LEI 2016-001

ISBN 978-94-6257-737-4
LEI Wageningen UR is een onafhankelijk, internationaal toonaangevend, sociaaleconomisch onderzoeksinstituut. De unieke data, modellen en kennis van het LEI bieden opdrachtgevers op vernieuwende wijze inzichten en integrale adviezen bij beleid en besluitvorming, en dragen uiteindelijk bij aan een duurzamere wereld. Het LEI maakt deel uit van Wageningen UR (University \& Research centre). Daarbinnen vormt het samen met het Departement Maatschappijwetenschappen van Wageningen University en het Wageningen UR Centre for Development Innovation van de Social Sciences Group.

De missie van Wageningen UR (University \& Research centre) is 'To explore the potential of nature to improve the quality of life'. Binnen Wageningen UR bundelen 9 gespecialiseerde onderzoeksinstituten van stichting DLO en Wageningen University hun krachten om bij te dragen aan de oplossing van belangrijke vragen in het domein van gezonde voeding en leefomgeving. Met ongeveer 30 vestigingen, 6.500 medewerkers en 10.000 studenten behoort Wageningen UR wereldwijd tot de aansprekende kennisinstellingen binnen haar domein. De integrale benadering van de vraagstukken en de samenwerking tussen verschillende disciplines vormen het hart van de unieke Wageningen aanpak. 